Claremont Colleges

Scholarship@ Claremont

1993

\title{
Academic Leadership in Advancement Activities: A Dimension of the Dean's Role in American Higher Education
}

Frank Cortez Flores Jr.

\section{Recommended Citation}

Flores, Frank Cortez Jr., "Academic Leadership in Advancement Activities: A Dimension of the Dean's Role in American Higher Education" (1993). CGU Theses \& Dissertations. Paper 84.

http://scholarship.claremont.edu/cgu_etd/84

DOI: $10.5642 /$ cguetd $/ 84$

This Open Access Dissertation is brought to you for free and open access by the CGU Student Scholarship at Scholarship @ Claremont. It has been accepted for inclusion in CGU Theses \& Dissertations by an authorized administrator of Scholarship @ Claremont. For more information, please contact scholarship@cuc.claremont.edu. 


\section{Abstract of the Dissertation}

ACADEMIC LEADERSHIP IN ADVANCEMENT ACTIVITIES:

A DIMENSION OF THE DEAN'S ROLE IN AMERICAN HIGHER EDUCATION

by

Frank Cortez Flores, Jr.

The Claremont Graduate School: 1993

In an atmosphere of declining support, rising costs, and an increasing emphasis on quality education, the need for effective fund-raising is important to American higher education. During the past decade, institutions of higher education, both public and private, faced difficult financial problems with no apparent end in sight. A growing number of colleges and universities have been threatened by the unstable economy and shrinking applicant pools and are faltering under this threat. Private higher education seems to be especially vulnerable to financial difficulty and has been historically dependent upon philanthropic support to complement traditional revenues in an effort to remain financially viable. As a result of this changing environment, the identification and development of enhanced and more diversified fund-raising strategies have emerged as one of the most significant and far-reaching needs presently confronting American higher education.

This study investigated and analyzed academic leadership and management of advancement activities in American higher education with particular attention given to schools of dentistry. It focused on how American schools of dentistry may organize and manage their fund-raising programs to maximize voluntary financial support. With the prospect of declining support and rising costs, an aggressive and effective fund-raising program is arguably crucial to their survival.

The study addressed the predominant organizational structure and management practices in the area of fund-raising at American schools of dentistry; the perceptions held by the deans and senior development officers in these same institutions as to the effectiveness of certain practices relating to fund-raising sources and constituencies, and methods and techniques used in their fund-raising programs; and the the emerging pattern which might serve as a model for development programs at American schools of dentistry or other institutions of higher education. 
The study is composed of the entire population - a census of American schools of denistry. Forty-five institutions $(45 / 55)$ in thirty states, including Puerto Rico $(30 / 34)$, participated in the survey and thirty-five deans $(35 / 55)$ and thirty-five development officers $(35 / 55)$ responded to the survey. The questionnaire is the principal means of data collection with a structured personal interview limited to the dears and development officers of the five California schools of dentisty. The deans and development officers cooperating in this survey give evidence that their major development-related functions are consistent with trends toward greater specialization in fund-raising. A high percentage ( 87.5 percent) of the dean respondents acknowledge affirnatively to making use of strategic planning as a management tool for the school's advancement activities. The dean respondents characterized the alumni as the most impotant giving constituency and the annual fund as the principal funding source. They also regard personal visits as the most effective method of soliciting funds for their instititions. The development officer respondents emphasized ideas, goals, and direcions of their school's advancement program while being most aware of the specific mectanics of fund-raising. The guiding outlines of a model development program for Ameican schools of dentistry appear to emerge from this exploratory study. 


\title{
ACADEMIC LEADERSHIP IN ADVANCEMENT ACTIVITIES: \\ A DIMENSION OF THE DEAN'S ROLE IN \\ AMERICAN HIGHER EDUCATION
}

\author{
By \\ Frank Cortez Flores, Jr.
}

A Dissertation submitted to the Faculty of The Claremont Graduate School in partial fulfillment of the requirements for the degree of Doctor of Philosophy in the Graduate Faculty of Education.

Claremont, California

1993

Approved by: 
We, the undersigned, certify that we have read this dissertation and approve it as adequate in scope and quality for the degree of Doctor of Philosophy.

Dissertation Committee:

Chair : Jack H. Schuster

Member: Daryl G. Smith

Member: David E. Drew

Member:

Visiting Examiner: Roberta Stathis 


\section{ACKNOWLEDGEMENTS}

I wish to express appreciation to the members of my dissertation committee who guided me and inspired me in the research and writing of my dissertation:

. Professor Jack H. Schuster, Chairman - mentor and friend, who introduced me to the history of higher education and the professoriate;

- Professor Daryl G. Smith - who introduced me to the culture and governance in higher education;

- Professor Joseph G. Weeres - who encouraged me to gather, analyze and write with clarity; and

- Professor David E. Drew - who introduced me to statistical analysis in higher education.

and to recognize:

Roberta Stathis, Ph.D. who graciously served as my visiting examiner.

I would also like to acknowledge the kind regard, counsel, and hospitality that was extended to me by John W. Crowe of the University of Southern California and to thank Fay Rulau of The Claremont Graduate School for her diligence and excellent job of typing the revisions for the final copy of the entire text.

Others, too, were an enormous help in the production of my dissertation, and I would like to thank them all for their support and assistance in the difficult project of attempting to capture the complexity of academic leadership and advancement activities in American higher education in so few pages.

Appreciation is also extended to The Claremont Graduate School - who honored me with a fellowship for my doctoral studies.

Additionally, I am deeply indebted to my parents - who nurtured me with love.

Finally, I am especially indebted to my Heavenly Father, who made me be and who made it all happen. 


\section{TABLE OF CONTENTS}

ABSTRACT

ACKNOWLEDGEMENTS

CHAPTER

PAGE

I Academic Leadership and Philanthropy in American Higher Education

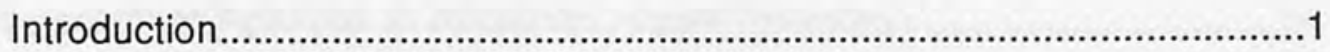

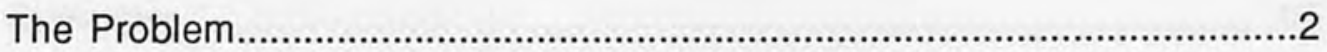

Significance and Purpose

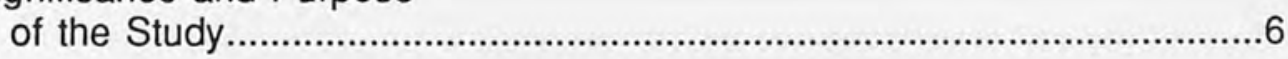

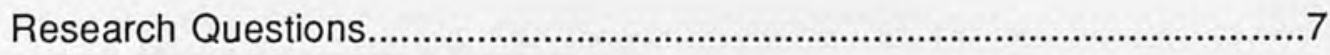

The Composition of the Study and Framework of Subsequent Chapters...................................................

II Academic Leadership and Management of Advancement Activities in American Higher Education

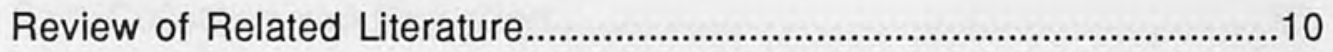

Educational Philanthropy: A Historical Perspective..............................11

Academic Leadership: The Role of the Dean............................................16

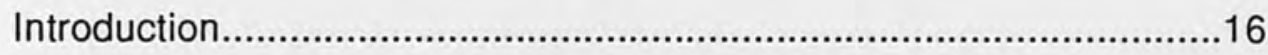

Academic Administrative Models......................................................24

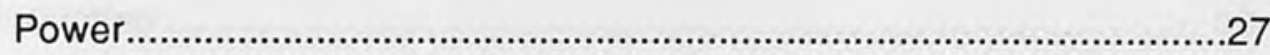

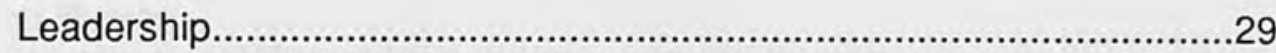

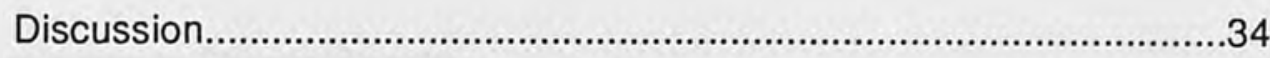

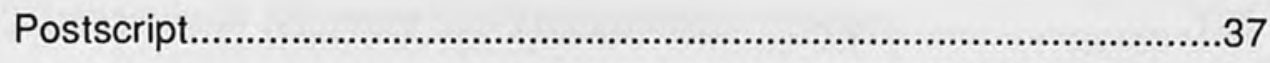


II Academic Leadership and Strategic Planning.................................................39

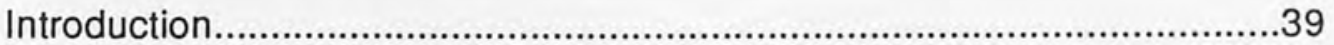

Strategic Planning in Academic Management.........................................42

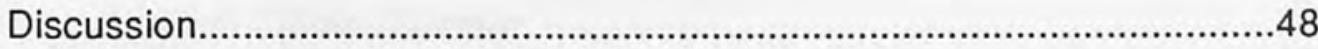

Advancement Activities In American Higher Education..................................54

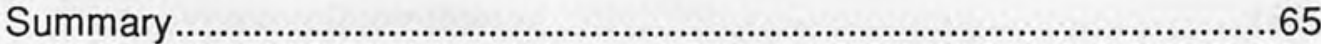

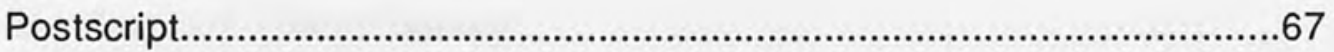

III Research Methodology and Procedures

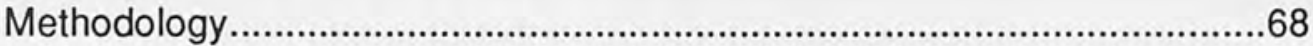

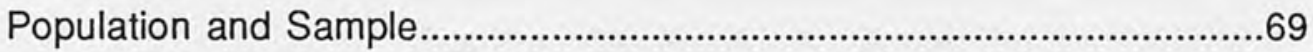

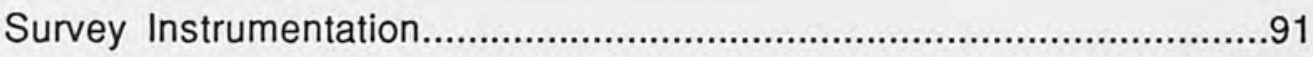

Data Collection and Recording................................................................93

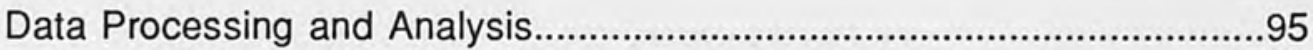

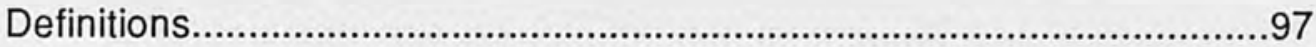

IV Analysis and Interpretation of Data

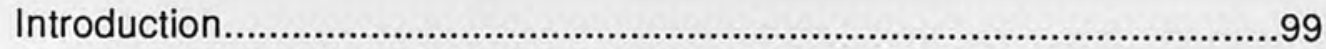

Dean Survey

Organizational Structure and Management Practice..........................101

Development Officer Survey

Organizational Structure and Management Practice. 
IV Development Officer Survey

Fund Raising Sources, Constituencies, and Record Keeping...............126

Dean Survey

Fund Raising Methods and Techniques.............................................131

Development Officer Survey

Fund Raising Methods and Techniques..............................................140

Dean Survey

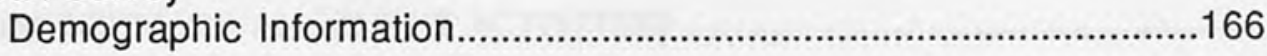

Development Officer Survey

Demographic Information................................................................172

Dean Interview and Development Officer Interview............................176

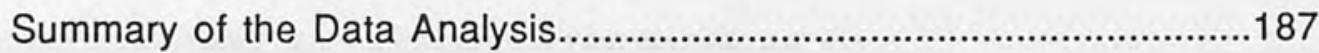

V Summary, Conclusions, and Recommendations

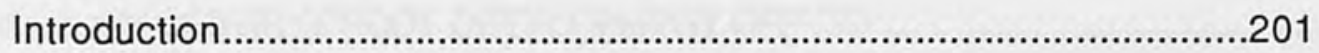

Research Procedures.......................................................................202

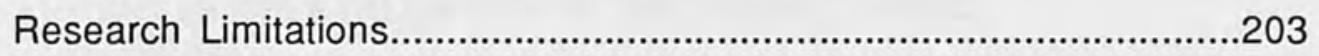

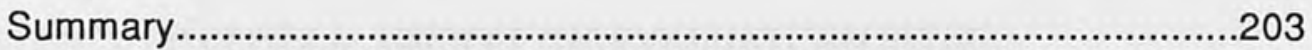

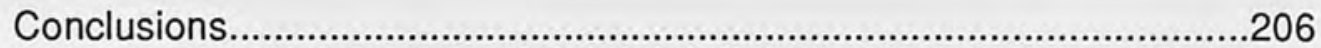

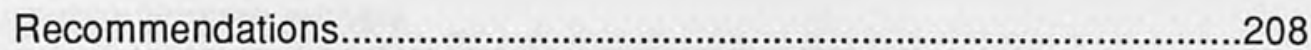

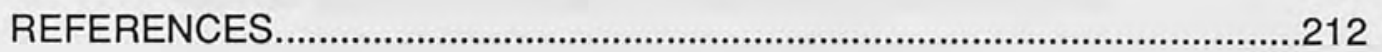

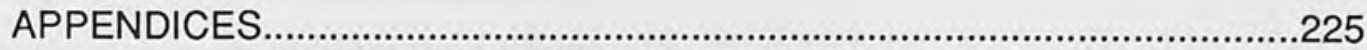




\section{LIST OF TABLES}

3.1 POPULATION OF THE STUDY

3.2 A SURVEY OF AMERICAN SCHOOLS OF DENTISTRY DEANS INSTITUTIONAL INFORMATION.

DEAN SURVEY

ORGANIZATIONAL STRUCTURE AND MANAGEMENT PRACTICE

4.1 INVOLVEMENT IN ADMINISTRATION POLICY FOR ADVANCEMENT ACTIVITIES

4.2 INVOLVEMENT IN ADVANCEMENT ACTIVITIES .104

DEVELOPMENT OFFICER SURVEY

ORGANIZATIONAL STRUCTURE AND MANAGEMENT PRACTICE

4.3 FOUNDING YEAR OF THE DEVELOPMENT OFFICE

4.4 DEVELOPMENT OFFICER'S REPORTING RESPONSIBILITY ................................................111

4.5 NUMBER OF DEVELOPMENT OFFICE PERSONNEL ……...................................................117

4.6 YEARS EXPERIENCE AS A DEVELOPMENT PROFESSIONAL_..............................................118

4.7 INCUMBENCY OF THE SCHOOL DEVELOPMENT OFFICER ………………………….........119

4.8 INVOLVEMENT IN THE SCHOOL'S CASE STATEMENT ......................................................121

4.9 INVOLVEMENT IN THE EVALUATION OF THE SCHOOL'S FUND RAISING PROGRAM

4.10 IMPORTANCE OF CRITERIA USED IN THE EVALUATION OF THE SCHOOL'S FUND RAISING PROGRAM.

DEVELOPMENT OFFICER SURVEY

FUND RAISING SOURCES, CONSTITUENCIES AND RECORD KEEPING

4.11 EFFECTIVENESS OF CONSTITUENCES IN PROVIDING SUPPORTING

FUNDS

4.12 EMPHASIS ON FUNDING SOURCES.

4.13 TOTAL NUMBER OF STORED RECORDS. 
DEAN SURVEY

FUND RAISING METHODS AND TECHNIQUES

4.15 EFFECTIVENESS OF THE DEVELOPMENT OFFICE IN COMMUNICATING ITS ROLE.

4.16 IMPORTANCE TO DEVELOPMENT FOR THE DEAN'S OFFICE TO PUBLICIZE SCHOOL ACTIVITIES

4.17 EFFECTIVENESS OF THE SCHOOL COMMUNICATING ITS CASE FOR PHILANTHROPIC SUPPORT..

4.18 EFFECTIVENESS OF THE UNIVERSITY DEVELOPMENT OFFICE AIDING SCHOOL DEVELOPMENT.

4.19 IMPORTANCE OF THE SCHOOL'S PUBLIC IMAGE TO DEVELOPMENT.

4.20 EMPHASIS ON IMPROVING THE SCHOOL'S PUBLIC IMAGE.

4.21 EMPHASIS ON THE DEAN'S VISITS TO FUND RAISING EFFORTS. 136

DEVELOPMENT OFFICER SURVEY

FUND RAISING METHODS AND TECHNIQUES

4.22 INVOLVEMENT OF THE DEAN, ALUMNI SUPPORT GROUPS (ASG) AND UNIVERSITY DEVELOPMENT OFFICE (UDO) IN THE SCHOOL'S ADVANCEMENT ACTIVITIES

4.23 INVOLVEMENT OF THE DEAN IN THE SCHOOL'S ADVANCEMENT ACTIVITIES.

4.24 INVOLVEMENT OF ALUMNI SUPPORT GROUPS IN THE SCHOOL'S ADVANCEMENT ACTIVITIES.

4.25 INVOLVEMENT OF THE UNIVERSITY DEVELOPMENT OFFICE IN THE SCHOOL'S ADVANCEMENT ACTIVITIES.

4.26 IMPORTANCE OF COORDINATING THE RELATIONSHIP BETWEEN SCHOOL AND UNIVERSITY DEVELOPMENT..

4.27 EFFECTIVENESS OF THE COORDINATION MENTIONED IN TABLE 4.26. .146

4.28 EFFECTIVENESS OF THE DEAN'S OFFICE IN COMMUNICATING ROLE OF DEVELOPMENT OFFICE.

4.29 IMPORTANCE TO SCHOOL DEVELOPMENT FOR THE DEAN'S OFFICE TO ASSIST IN FUND RAISING EFFORTS 
4.30 DILIGENCE (ACTIVENESS) OF THE DEAN'S OFFICE IN PUBLIZING SCHOOL ACTIVITIES

4.31 EMPHASIS ON THE IMPROVEMENT OF THE SCHOOL'S PUBLIC

IMAGE.

4.32 EMPHASIS ON PERSONAL VISITS BY THE SCHOOL DEVELOPMENT OFFICER

4.33 IMPORTANCE OF PERSONAL VISITS TO THE SCHOOL'S FUND

RAISING EFFORTS

4.34 EMPHASIS ON PROSPECT RESEARCH.

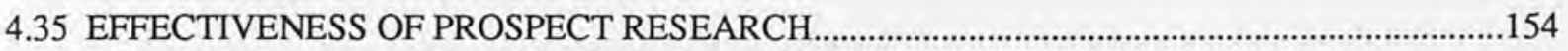

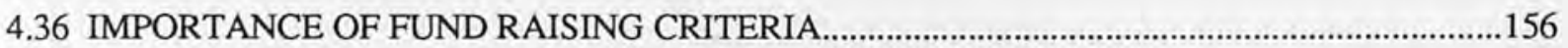

4.37 EFFECTIVENESS OF FUND RAISING METHODS AND TECHNIQUES...............................159

4.38 ATTRACTIVENESS OF VARIOUS GIFT-USES TO DONORS..................................................162

DEAN SURVEY

DEMOGRAPHIC INFORMATION

4.39 ETHNICITY: DEANS

4.40 GENDER: DEANS. 166

4.41 AGE: DEANS 167

4.42 TENURE OF THE DEANS AT THEIR CURRENT SCHOOL .168

4.43 YEARS OF PRIOR ADMINISTRATIVE EXPERIENCE AS DEAN 169

4.44 YEARS OF PRIOR ADMINISTRATIVE EXPERIENCE AS ASSISTANT/ASSOCIATE DEAN.

4.45 YEARS OF PRIOR ADMINISTRATIVE EXPERIENCE AS DEPARTMENT CHAIRPERSON..

DEVELOPMENT OFFICER SURVEY

DEMOGRAPHIC INFORMATION

4.46 ETHNICITY: DEVELOPMENT OFFICE

4.47 GENDER: DEVELOPMENT OFFICER 
4.49 TENURE OF THE DEVELOPMENT OFFICERS AT THEIR CURRENT SCHOOL

4.50 YEARS OF PRIOR ADMINISTRATIVE EXPERIENCE AS A DEVELOPMENT OFFICER

DEAN'S INVOLVEMENT IN ADVANCEMENT ACTIVITIES:

COMPARING PERCEPTIONS OF DEANS AND DEVELOPMENT OFFICERS

4.51 T-TEST FOR: SEEKING FINANCIAL SUPPORT 197

4.52 T-TEST FOR: SOLICITING MAJOR DONOR 197

4.53 T-TEST FOR: SOLICITING POTENTIAL DONOR 198

4.54 T-TEST FOR: EVALUATING FUND RAISING PROGRAMS 198

4.55 T-TEST FOR: ESTABLISHING FUND RAISING POLICY 199 


\section{LIST OF FIGURES}

1. ORGANIZATIONAL DIAGRAM OF RESPONDING SCHOOLS OF DENTISTRY: DEVELOPMENT OFFICER'S REPORTING STRUCTURE A

2. ORGANIZATIONAL DIAGRAM OF RESPONDING SCHOOLS OF DENTISTRY: DEVELOPMENT OFFICER'S REPORTING STRUCTURE B

3. ORGANIZATIONAL DIAGRAM OF RESPONDING SCHOOLS OF DENTISTRY: DEVELOPMENT OFFICER'S REPORTING STRUCTURE

4. ORGANIZATIONAL DIAGRAM OF RESPONDING SCHOOLS OF DENTISTRY: DEVELOPMENT OFFICER'S REPORTING STRUCTURE D

5. ORGANIZATIONAL DIAGRAM OF RESPONDING SCHOOLS OF DENTISTRY: DEVELOPMENT OFFICER'S REPORTING STRUCTURE E 


\section{LIST OF APPENDICES}

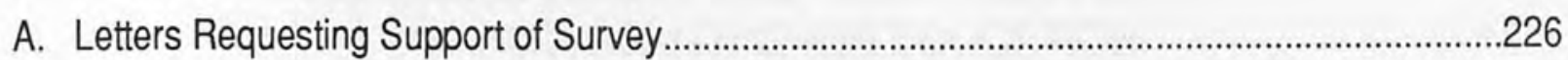

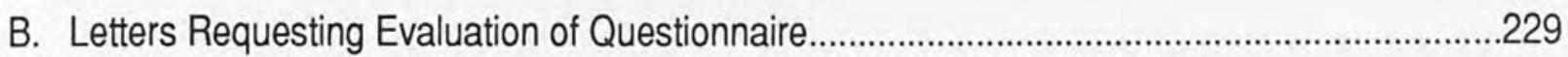

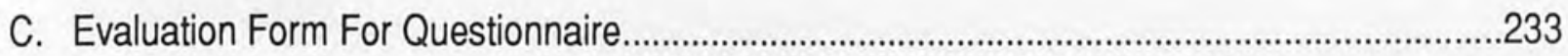

D. Initial Cover Letters and Follow-Up Letter for Questionnaire...................................................235

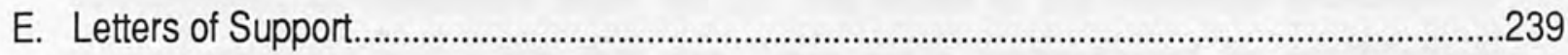

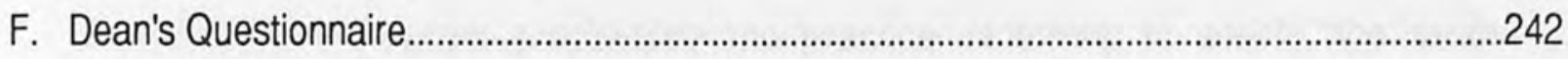

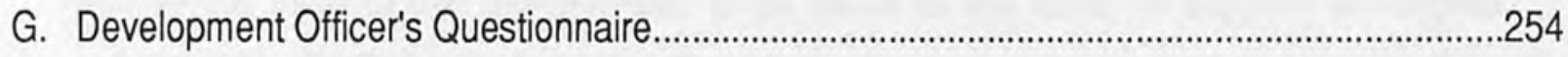

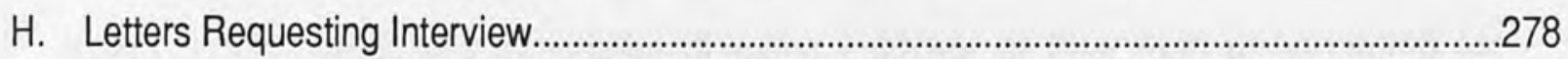

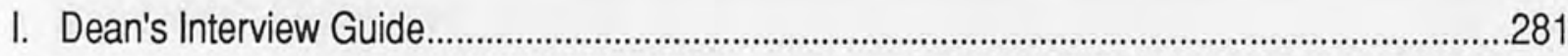

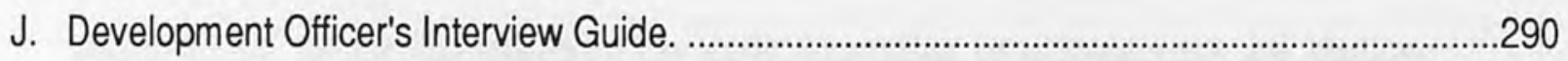

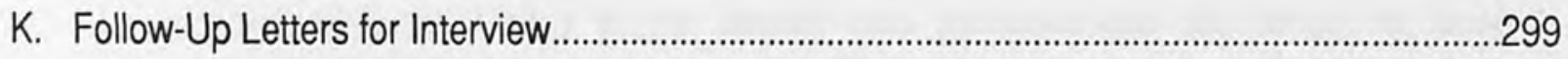

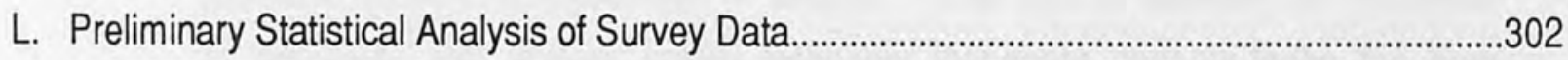

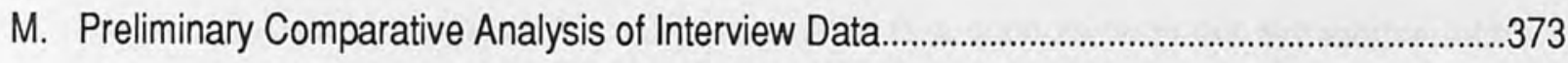

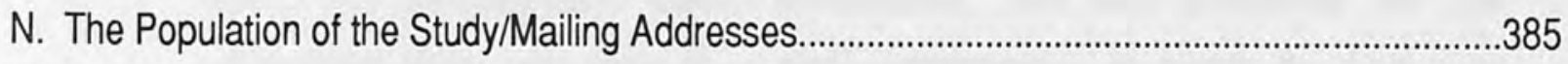




\section{CHAPTER 1}

\section{ACADEMIC LEADERSHIP AND PHILANTHROPY IN AMERICAN HIGHER EDUCATION}

\section{INTRODUCTION}

A. C. Marts (1953) has described philanthropy as "a true measuring rod of the development of civilization itself" (p. 3). He writes of the historical antecedents of philanthropy by noting that the Jews were instrumental in establishing philanthropic principles, particularly the practice of tithing in which "the tenth part of the yield of the harvest was to be given to the Lord, in support of religion and for the relief of the poor" (p. 4). Marts goes on to note that at harvest time many Jewish landowners pledged to leave a corner of their field unharvested for the benefit of the poor.

Marts sums up his commentary on early examples of philanthropy by stating:

All through the history of the Jewish race righteousness has found its most practical and fervid expression in charity. "The Cell of Silence" or "Chamber of Whispers" was a later Jewish technique that came near to being the ideal exercise of charity. This name was given to a quiet room in the synagogue into which the philanthropic stole, unobserved, and left donations for the respectable poor, who stole in -- also unobserved -- to obtain the help they needed. (p. 4)

According to Broce (1979), historically, private philanthropy once thrived in England and in Western Europe. However, this custom has been, for the most part, relinquished to the government, which now regulates and sustains through taxation most religious, cultural, and educational institutions.

Philanthropic support of American higher education has a long tradition and the largest portion of that philanthropy has historically been directed to private 
institutions. However, both public and private higher educational institutions are now facing critical financial problems as a result of declines in resources, rising costs, and an unstable national economy. These problems have placed extraordinary demands on these institutions to identify and consider alternative sources of funds. Therefore, it is of great consequence to investigate and analyze methods of enhancing philanthropy to American higher education.

\section{THEPROBLEM}

In an atmosphere of an increasing emphasis on quality education, declining enrollments, and rising costs, the need for effective fund raising is of high priority to American higher education. During the past decade, institutions of higher education, both public and private, have faced difficult financial problems with no apparent end in sight. A growing number of colleges and universities have been threatened by the unstable economy and shrinking applicant pools and are faltering under this threat. Private higher education seems to be especially vulnerable to financial difficulty and has been historically dependent upon philanthropic support to complement traditional revenues in an effort to remain financially viable. As a result of this changing environment, the identification and development of an enhanced and more diversified fund raising strategies has emerged as one of the most significant and far-reaching needs presently confronting American higher education.

The financial crisis in American higher education and the financial constraints which are placed upon colleges and universities are well documented. Howard R. Bowen (1983), Avery Professor of Economics and Education at The Claremont Graduate School, wrote cogently:

American colleges and universities are in considerable distress as they face the necessity or the prospect of budget cutting. They are troubled because their hopes for rising quality of education and widening access for students are being thwarted. Faculty and staff are insecure and discouraged. Many of those presidents and deans who have dared to propose specific budget cuts are under 
siege. The magnitude of the problem varies among institutions, but few are totally exempt. It is not a happy time in academe. (p. 21)

In a well-documented study, Keller (1983) points out:

Fewer than 50 of America's 3100 colleges and universities have endowments of $\$ 100$ million or more and fewer than 200 have an endowment larger than $\$ 10$ million. Nine out of ten institutions in the United States, therefore, are precariously financed and many live on the brink of jeopardy and instant retrenchment. (p. 152)

American higher education is experiencing significant changes in its environment as it enters a critical period in its economic development. The continually rising cost of education, a steady decline in student enrollments, reductions in governmental support, and an economy burdened with rampant inflation, along with numerous other factors have combined to intensify financial problems at American institutions of higher education.

According to Williamson (1975):

After two decades of relative prosperity, colleges and universities are now facing critical financial problems. Higher education is confronted with the harsh reality of both a slowdown in enrollments and a continuing rise in costs. ...it is clear that the premises and policies appropriate in an era of rapid growth are inappropriate for an era of slowdown and uncertainty. (p. 23)

In an investigation of the critical financial problems confronting American colleges and universities, Mayhew (1977) supports Williamson's findings. Mayhew stated:

Just as suddenly as higher educational affluence and support had come, it began to go, between 1968 and 1970 . And, as was true of the "golden years," the indices of changed conditions can be quickly enumerated and are for the most part well known. Suddenly institutions found that their rates of increase of total revenue, and the reserves that had been built up during the 1960's were 
quickly eliminated through deficit spending... thus a downward spiral was initiated, with lower enrollments generating less income with which to support fixed and increasing costs. (p. 265)

In an educational climate with limited financial resources in an inflationary economy, Bowen and Schuster (1986), in a scholarly and thought-provoking study, make a strong case for improvement in faculty compensation and in the work environment. They emphasize the need for a greater national investment in faculty compensation, as well as replacement of obsolete equipment and deteriorating buildings.

However, the current financial crisis in American colleges and universities conceivably could be addressed through the use of enhanced and effective fund raising activities. For, as Bowen (1983) noted perceptively:

Another possibility for helping to balance a reduced budget is to augment income --for example, ...seeking increased gifts from private sources or grants from public sources, and embarking upon profit-making activities...(p. 21)

Citing his earlier study (1980), Bowen (1983, p. 21) further noted:

The comprehensive budgets of colleges or universities, on the average, are divided into four parts with approximate percentages as follows:

Personnel (Salaries and Fringe Benefits)

Faculty $25 \%$

Administrative $14 \%$

General Service Workers $18 \%$

Subtotal (Personnel) $57 \%$

Non-Personnel Expenditures:

Construction Equipment, Supplies, Library Books, Fuel, Utilities, Other Purchased Goods and Services, Student Aid, etc. 
These trends signal a new dimension in the financing of higher education. The need to respond to burgeoning financial claims is compelling American colleges and universities to enhance their fund raising strategies and activities.

As noted by Rowland (1978):

Every American enterprise that depends, to whatever degree, on gift income knows that institutional survival is in serious jeopardy. Private schools, colleges, hospitals, and churches are especially threatened, and some have closed their doors in the recent past. Those that depend primarily upon public funds face growing taxpayer resistance, and are re-evaluating the quality and quantity of their services. In the years ahead, fund raising success will be more important than ever before. (p. 265)

Finally, since the late 1960's, the state of higher education has gone from one of unprecedented growth to one of financial constraint. In spite of the increasing uncertainty that has accompanied higher education through the seventies, the eighties, and into the nineties, the pace of change in the academic leadership and management in higher education has been measured for a variety of reasons. Academic leaders with managerial and technical skills are playing a greater role in determining funding priorities, setting operational procedures, and planning for the future of their institution. As observed by Socolow (1978):

...given the difficult times with which higher education is now faced, it might be expected that some institutions would break with tradition and begin looking for leaders with other kinds of experience and background. (p. 42)

Accordingly, this study will investigate and analyze academic leadership and management of advancement activities in American higher education with particular attention given to schools of dentistry. It focuses on how American schools of dentistry may organize and manage their fund raising programs to maximize voluntary financial support. With the prospect of declining enrollments and rising costs, an aggressive and effective fund raising program is arguably crucial to their survival. 


\section{SIGNIFICANCE AND PURPOSE OF THE STUDY}

American higher education has been in a state of transition and upheaval since the founding of Harvard College in 1636 which is credited with the beginning of higher education in America. Moreover, in an era of rapidly accelerating change, higher educational institutions today are confronted with a crisis of purpose, erosion of traditional values, declining public support, increasing competition for scarce resources, demands for accountability and a struggle for survival. At no time in the history of American higher education has it been more important for decision makers in college and universities to understand the dynamics of philanthropy and institutional renewal.

This study will address the problem of how American schools of dentistry may organize and manage their fund raising programs to maximize voluntary financial support. This will be done by exploring:

The predominant organizational structure and management practices in the area of fund raising that have evolved at selected schools of dentistry;

The perceptions held by the deans and development officers in these same institutions as to the effectiveness of certain practices relating to fund raising sources and constituencies, and methods and techniques used in their fund raising activities. These methods and techniques represent what may be considered the result of effective and successful plans; and

The emerging pattern which might serve as a model for development programs at other American institutions of higher education.

For purpose of this study and as a guiding principle, the terms fund raising. advancement activities, and development are used interchangably. 


\section{RESEARCHQUESTIONS}

The study is designed to be descriptive in nature, utilizing interviews, document review, and survey research methodology. The study will be guided by the following major questions:

. What are the main criteria or characteristics of an ideal development program?

- How can individual schools of dentistry or other institutions of higher education best take advantage of the findings of this study for their development program?

Specifically, this study is designed to research the following questions:

1. How is fund raising organized for American schools of dentistry? What specific organizational fund raising structures exist within schools of dentistry?

a. Do these schools of dentistry typically have a separate development office?

b. What is the title of the school development officer?

c. What is the reporting relationship? Who has the lead responsibility and to whom do they report?

d. How does this reporting relationship fit into the organization?

2. Within schools of dentistry, what are the major development-related functions (such as annual giving, deferred giving, and capital gifts)? 
3. What are the specific management practices relative to planning, policy formulation, evaluation, and records management in the sphere of fund raising?
a. What is the role of the dean relative to planning, policy determination, and solicitation of funds?
b. How does the role of the dean fit into the organization?
c. Is strategic planning or some other identifiable management technique utilized to facilitate fund raising?

4. What are the major sources (for instance, alumni, corporations, foundations) from which American schools of dentistry realize their financial support?

5. What are the most effective fund raising techniques used in American schools of dentistry?
a. What types of strategies attract the largest gifts?
b. How are these effective operations planned, organized, and managed?
c. What did the deans characterize as the successful elements?
d. What did the school development officers characterize as the successful elements?

\section{THE COMPOSITION OF THE STUDY AND FRAMEWORK OF SUBSEQUENT CHAPTERS}

This study is composed of and organized around five chapters.

An introduction to the study, statement of the problem, significance and purpose of the study, and research questions have been presented in this first chapter.

Chapter two presents a review of related literature and research. Principal concepts reviewed include educational philanthropy: a historical perspective, 
academic leadership from the perspective of the deanship, strategic planning in academic management, and advancement activities in American higher education.

Chapter three includes a description of the methodology and procedure of research, population and sample, survey instrumentation, data collection and recording, and data processing and analysis.

Chapter four is focused on the analysis and interpretation of data obtained from the questionnaires and structured interviews and presents findings in the form of a brief reconsideration of the research questions in a summary of the data analysis.

Chapter five, the final chapter, contains a summary, research limitations, and includes conclusions and recommendations based on the results of the study. 


\section{ACADEMIC LEADERSHIP AND MANAGEMENT OF ADVANCEMENT ACTIVITIES IN AMERICAN HIGHER EDUCATION}

\section{REVIEW OF THE LITERATURE}

As a result of severe financial pressures stemming from increased costs, decline in student enrollment, reductions in governmental support and a shifting economy, American higher education has escalated its fund raising activities. According to the 1987 annual survey report (Voluntary Support of Education) conducted by the Council for Financial Aid to Education, (CFAE), in 1985-86, total voluntary support to higher education rose $\$ 1.8$ billion (a $25 \%$ increase over the previous year) to an estimated $\$ 7.4$ billion. Donations from corporations, alumni, foundations and other individuals accounted for over $90 \%$ of all support to American higher education in 1985-86. (p. 5)

This study will address a recognized need: enhancement of fund raising strategies as identified in the relevant literature. Its purpose is to provide an indepth analysis of the organization, management, and methods of fund raising at American institutions of higher education with particular attention given to schools of dentistry. The literature selected for review in this chapter is organized into four principal sections:

Educational philanthropy: A historical perspective

Academic leadership: The role of the dean

Academic leadership and strategic planning

Advancement activities in American higher education. 


\section{EDUCATIONAL PHILANTHROPY:A HISTORICAL PERSPECTIVE}

The earliest evidence of educational philanthropy according to Marts (1953) began with a bequest of land from Plato to provide for the continuity of his Athenian Academy in 347 B.C. Alexander the Great, because of his respect for learning and affection for Aristotle, generously supported Aristotle Lyceum with his wealth. According to McMahon (1949), the first formal fund raising effort was recorded at Oxford in the 15th Century. However, according to Muller (1977), private support of higher education, for the most part, is a unique American phenomenon. Therefore, in order to appreciably understand the present and likely future of this unique American phenomenon, an acquaintance, however briefly, with the history of American higher education is indicated.

Higher education in America began with the founding of Harvard College in 1636 and since then it has been shaped and influenced by a variety of educational, cultural and religious forces from England, Scotland and Europe. The role of American philanthropy was a key element in the development of a system of higher education unique to the United States.

\section{According to Rudolph (1962):}

Higher education in the colonies, beginning with Harvard College, could not have begun without the active support of a nucleus of Cambridge and Oxford trained gentlemen... they intended to recreate a little bit of Old England in America... it was no less natural for the Englishmen of early Massachusetts to found themselves a college, an English college such as those they had known at Oxford but particularly at Cambridge...(p. 4)

In discussing the development of American higher education, Clark (1987) suggests diversification, decentralization, and local autonomy as some distinguishing characteristics. However, he notes that the colonial college was accepted more as a public trust since it was chartered by the religious denomination or the government of the colony or both. Clark cites the work of 
Hofstadter and Metzger (1955), Rudolph (1962), and Whitehead (1975) in noting another factor unique to colonial American higher education: The first colleges were established in a sparsely populated rural setting lacking noteworthy resources. He writes:

The American colonies were hardly an appropriate setting for an autonomous profession... it took half a century before William and Mary (1693) and Yale (1701) followed the establishment of Harvard College. Only six other colleges succeeded them before the Revolutionary War, all erected in a sparsely populated territory devoid of old cities, a medieval heritage, and substantial resources... a type of institution that was to evolve into what we now call the private liberal arts college. This general type had its roots in England, where clusters of colleges composed Oxford and Cambridge, but the distinctive American pattern was to be the single college operating in isolation, preferably in a pastoral setting. (pp. 4-5)

Rudolph (1962) comments on the early role of philanthropy in insuring the continuity and viability of American higher education:

While the colonial economy could not support philanthropy of the dimension that founded colleges at Oxford and Cambridge, individual benevolence was nonetheless in the English tradition... John Harvard and Elihu Yale, while not founders of the colleges that took their names, were the first substantial private benefactors of collegiate education in New England and the first scholarship fund given to an American college was an act of Christian benevolence on the part of Lady Ann Mowlson whose maiden name had been Radcliffe. (p. 178)

Boorstin (1973) sums up his commentary on early examples of American educational philanthropy by stating:

The earliest American private colleges -- Harvard, Yale, Princeton, Dartmouth, Amherst -- had been founded with relatively small capital sums, aided later by generous public grants and by the modest philanthropy of their loyal sons. Then the booster colleges before the Civil War had depended on the 
meager resources of the denominations or on piecemeal support from local communities. The late years of the nineteenth century saw educational philanthropy on a new scale. In 1873, Johns Hopkins, from the fortune he had made as a commission merchant, banker, ship owner, and as the largest stock holder in the Baltimore \& Ohio Railroad, bequeathed $\$ 7$ million to found the Johns Hopkins University and the Johns Hopkins Hospital... Andrew Carnegie, from his steel millions, founded the Carnegie Institution (1902) to promote research, the Carnegie Foundation for the Advancement of Teaching (1905), and the Carnegie Corporation (1911) for science and the humanities. Leland Stanford, out of the fortune he had made in Western railroads, founded Leland Stanford, Jr. University in the memory of his son, and left it an additional \$2.5 million at his death. John D. Rockefeller, from his Standard Oil profits, gave $\$ 10$ million in 1891 to found the University of Chicago. James B. Duke, who built the American Tobacco Company, in 1924 created a trust, valued at some $\$ 100$ million to establish Duke University. (pp. 488-489)

When Daniel Webster so eloquently and effectively defended the independence of Dartmouth College from state governmental control before Chief Justice John Marshall and the United States Supreme Court in 1819, private colleges, henceforth, had a legal precedence for independence (Rudolph, 1962).

According to Rudolph (1962), the first university in the United States began with the establishment of Johns Hopkins in 1876. However, there had been a gradual evolution of college to university beginning in the 1850 s when Yale fostered graduate research and awarded the first American Ph.D. in 1861. Under the extended presidential leadership of Charles W. Eliot (1869-1909), who vigorously and effectively solicited funds, Harvard established a graduate department in 1870 , soon followed by other private colleges. Moreover, public or state universities were coming into existence, supported by the resources offered to the states by the federal government through the land grant legislation of the 1862 Morrill Act. 
Historically, the Morrill Act of 1862 was a significant investment by the federal government in higher education and according to Lee (1969), the first attempt by Congress to establish a national policy supporting higher education. However, it was not until 1890 and the passage of the second Morrill Act that federal support of higher education shifted from granting public lands to the states for the benefit of colleges within the state to federal grants in financial support of the development of state agricultural and mechanical schools.

Tiedt (1966) chronicles additional federal legislative acts which influenced higher education: the Hatch Act united agricultural experimental stations with the land-grant colleges which resulted in the promotion of agricultural research in higher education. The Smith-Lever Act (1914), which established the Agricultural Extension Service to "aid in diffusing among the people of the United States useful and practical information on subjects pertaining to agriculture and home economics."

Following World War I, the federal government enacted legislation to support programs for the rehabilitation of disabled veterans, the distribution of surplus federal property to education, and the establishment of the Reserve Officers' Training Corps at institutions of higher education. The Emergency Relief Act was passed in 1935 supporting various educational programs and the National Cancer Institute Act (1937) was enacted to provide funds for public health service fellowship. In 1944, Congress passed the Servicemen's Readjustment Act (G. I. Bill), by which the 78th Congress provided educational financial aid for World War II veterans, resulting in a dramatic increase in college enrollments. Congress also passed the Surplus Property Act in 1944.

After World War II, the federal government continued its support of higher education as catalogued by Knezevich (1975, pp. 270-274):
P.L. 83-13 (1953)
P.L. $83-531$ (1954)
P.L. $84-597$ (1954)
Created H.E.W.
Cooperative Research Act
Library Service Act 


$\begin{array}{lll}\text {. } & \text { P.L. } 85-865(1958) & \begin{array}{l}\text { National Defense Education Act } \\ \text { (NDEA) }\end{array} \\ \text {. } & \text { P.L. } 88-204(1963) & \begin{array}{l}\text { Higher Education Facilities Act } \\ \text { Amendments to NDEA (1964) }\end{array} \\ \text {. } & \text { P.L. } 89-329(1965) & \begin{array}{l}\text { Higher Education Act } \\ \text {. }\end{array} \\ \text {. P.L. } 89-698(1966) & \text { International Education Act } \\ \text {. P.L. } 92-318(1972) & \text { P.L. } 92-607(1972) & \text { Education Amendments } \\ \text { Supplemental Appropriation }\end{array}$

A review of the literature, A Fact Book on Higher Education (1968); Wolk, R. A. (1968), Alternative Methods of Federal Funding for Higher Education: Federal Support to Universities and Colleges. FY 1963-1966 (1967); and Federal Support to Universities and Colleges. FY 1967 (1969), revealed five categories in which Congress usually supports higher education:

Aid to Students - Grants or loans direct to students or through institutions to cover all or part of educational expenses;

Categorical Aid - Funds provided through grants, contracts, or loans in support of a specific project or goal designated by the granting agency;

Grants to Institutions - Funds provided to institutions for broad or undesignated purposes;

Revenue Sharing - The return to the states of certain tax monies collected by the federal government; and

Tax Relief - Assistance to taxpayers for educational expenses through exemptions, deductions, or credits in the payments of taxes (tax relief may also go to institutions and may cover donations as well as expenses). 


\section{ACADEMIC LEADERSHIP: THE ROLE OF THE DEAN}

\section{INTRODUCTION}

The description in the literature of effective academic leaders is that these leaders are trustworthy, have a clear vision of their school's future, and are able to inspire a shared vision among divergent individuals and groups (Bennis and Nanus, 1985). According to Dibden (1968), academic deans are concerned with the effective functioning of an educational unit, promoting scholarship among faculty, facilitating the development of academic programs that expand the intellect of students, and managing the academic budget.

From an historical perspective, as early as the 4th century A.D., the title dean originated with the Romans and was assigned to positions related to a military grade; and later on the Romans and Anglo-Saxons incorporated the name with civil administration. In medieval times, the deacon in the church had control over the religious and educational lives of monks. Because the universities of the mid-twelfth century were closely related to church schools, several titles used by the church became part of the academic structure. Although these positions commanded different degrees of power and authority, all of the role occupants were expected to perform leadership functions (Hodges and Hodges, 1975).

The variability in the role has been attested to by recognized leaders in higher education including incumbents in the position. McGannon (1973, p. 277) noted that the deanship required a "Man for all Seasons," a position that assumed the responsibilities and leadership functions of an industrial executive within the framework of the traditions, values and ideas of the academy. Dill (1980 p. 261) observed that deanships are "ephemeral creatures of place, time, discipline, personality, and circumstances," while Corson's frequently quoted statement $(1975$, p. 253$)$, "assessing the role of the dean is akin to that of drawing a bead on a moving target," lends further credence to the role's formless and perhaps indescribable character. 
While the foregoing commentary describes the deanship position as unpredictable and amorphous, agreement was evident in the literature that deans with specific attributes were more successful in their positions. Linnell (1974) and Barrett (1974) encouraged deans to act as enablers and facilitators by assisting faculty to achieve greater growth and self-fulfillment, and as catalysts by encouraging new ideas and questioning proposals. Because of its strategic placement in higher education, the deanship is one of the academy's most influential positions. Deans are expected to be expert managers, skilled in institutional goal setting and evaluation, administrators versed in negotiation and arbitration, and futurists equipped with a vision of tomorrow's world and the ability to lead others in that direction (Buchen, 1974).

However, there is a lack of theory and research on the deanship according to Griffith and McCarthy (1980): "While those who administer higher education are represented by a literature whose chief characteristic is poverty, the least among the poorest is the deanship. There has been so little theoretical, conceptual, or research literature published on the deanship as to constitute an embarrassment to both the practitioners and scholars of higher education" (p.V).

In contrast to the lack of study on the deanship, research on leadership has a long history. In 1939, Lewin, Lippitt, and White's study delineated the renowned Autocratic, Democratic, and Laissez-faire Leadership Styles. Until the 1950's, most research attempted to discover specific traits of leaders which could elucidate the personal qualities necessary for leadership. The results were inconclusive (Stogdill, 1974). The Ohio State Leadership Studies and studies at the University of Michigan and Harvard University began an era of behavioral research. Much research and theoretical efforts since the early 1950's indicated that a situational approach to leadership is favored. That is, the most effective kind of leadership depends on the characteristics of the leader, the followers, and the "situation" (Stogdill, 1974). 
The situational approach to leadership as synthesized from research by McGregor (1976) proposed that leadership is a behavioral process involving variables in four categories:

1. The characteristics of the leader;

2. The attitudes, needs, and other personal characteristics of the followers;

3. Characteristics of the organization, such as its purpose, its structure, the nature of the tasks to be performed; and

4. The social, economic, and political milieu, (pp.18-19).

McGregor, however, did not specify the "complex relationships among these variables" (p. 19). He summarized the effects of the situational influences by saying that the "differences in requirements for successful leadership in different situations is more striking than the similarities" (p. 21).

A prime assumption of the present study on academic leadership is, arguably, as the chief administrative officer in an academic program, the dean is essential to organizational vitality, integrity, and growth. It is the dean, in this role, who provides the leadership, resources, and incentives to enable faculty to carry out the mission of the college. Ostensibly, in fulfilling this role, academic leaders experience advantages and disadvantages, costs and rewards.

This study will endeavor to address the issue that there is much disagreement about definitions of leadership and about its substantive nature. As Spotts (1974) observed: "The general conclusion that one might draw is that there is very little consensus about what leadership is or what it should be" (p. 11). This observation was confirmed by Stogdill (1974) when he stated: "There are almost as many different definitions of leadership as there are persons who have attempted to define the concept" (p. 7). Not only are there disagreements about how leadership is defined, others question whether leadership makes a difference in outcomes. 
March (1982) challenges the belief in the efficacy of leadership as well as the reliability of leaders success. He noted:

It seems likely that the difference between a successful leader and an unsuccessful leader is less than we believe, and it seems possible that we may want to question the conventional idea that great leader action should be built on great expectations for the consequences of action. (p. 17)

\section{According to Birnbaum (1989):}

It is easy to talk about organizational leadership but difficult to study it. Literally thousands of essays, research reports, and other scholarly and practical works have provided a rich pool of provocative but often conflicting ideas. Although we have learned much about leadership, there is still no agreement on how leadership is defined, measured, assessed, or linked to outcomes and "no clear and unequivocal understanding... as to what distinguishes leaders from nonleaders, and perhaps more important, what distinguishes effective leaders from ineffective leaders" (Bennis and Nanus, 1985 , p. 4).

Most studies of leadership have taken place in business organizations, the military, and government agencies, with little attention given to higher education (Vroom, 1983). Studying leadership in colleges and universities is even more difficult than in other settings because of the dual control systems, conflicts between professional and administrative authority, unclear goals, and other properties unique to normative, professional organizations.

Particularly problematic is the relationship between leaders and those whom they presume to lead. Some theoretical approaches assert that "leadership" in organizations can be understood only in the context of "followership." But in higher education, there is a strong resistance to leadership as it is generally understood in more traditional and hierarchical organizations, and it is often more accurate to think of faculty as constituents rather than as followers. (pp. 125-126) 
Despite these pessimistic observations, an impressive body of research has been conducted regarding the nature of leadership as well as its effects on followers. Stogdill (1974, pp. 7-16) summarized this research, noting that it fell into eleven classification schemes:
- Leadership as a focus of group process;
- Leadership as personality and its effects;
- Leadership as the art of inducing compliance;
- Leadership as the exercise of influence;
- Leadership as an act or behavior;
- Leadership as a form of persuasion;
- Leadership as a power relation;
- Leadership as an instrument of goal achievement;
- Leadership as an effect of interaction;
- Leadership as a differentiated role; and
- Leadership as the initiation of structure.

For the purpose of this study, leadership is defined as the behavior of individuals as they direct the activities of their group toward goal-setting and goalachievement (Hemphill and Coons, 1957; Stogdill, 1959).

One method of identifying the diversity of organizational characteristics in higher educational institutions was proposed by Baldridge, Curtis, Ecker, and Riley (1978). In a four-year study of academic governance, they found that colleges and universities varied in governance characteristics according to the organizational variables of institutional control (public or private), educational task, faculty characteristics, and size. The possible implications for deans' leadership behaviors can only be inferred from this study which focused on the top level administration and the parent institution. Further study is necessary to see if deans' leadership behaviors are related to the program and institutional
characteristics. 
Literature on leadership style suggests that educational administrators are perceived most effective when they score high on leadership styles identified as Initiating Structure (those who have clearly defined their own roles and let others know what is expected of them) and Consideration (those who regard the comfort, well-being, status, and contributions of others) (Kuntz and Hoy, 1974). Earlier studies speculate that educational administrators declined to stress the Initiating Structure Style of leadership because human relations and group dynamics are emphasized in education (Kuntz and Hoy, 1974). However, Halpin's research (1958) found that educational administrators can Initiate Structure without sacrificing Consideration. Although Halpin's early studies were done to assess effective leadership styles of superintendents of public schools, his studies have been generalized to include other educational administrators. Halpin maintains that in education there is a high value placed on Consideration Styles, and Initiating Structure Style is not a dominant theme of institutional mores.

Role theorists suggest, as did Shakespeare, that in the social world we are all actors, with scripts to follow, norms to which we must adhere, and dictates with which we must conform. Sociologists further imply that roles, or positions, carry with them expectations of incumbents. That which sociologists have not thoroughly addressed however, is the impact that a lack of perceived legitimacy, either on the part of the player or the audience, has on the ability of the player to fully enact a role.

From the perspective of the social scientist, there are three general classes of expectations that have impact upon the way one enacts a particular role. These include the script, the other players, and the audience (Turner, 1978). In the theatrical sense, the script refers to norms or standards of behavior in a given role. The other players are those with whom the role player interacts and from whom demands are perceived. The audience, or those in status positions, similarly influence performance, in that their expectations guide conduct. It is generally accepted that the organizational context, or audience, will determine 
role expectations to a greater extent than will either the script or the other players.

Turner (1978), a noted critic of role theory and proponent of interactionism, has offered conditions under which, he suggests, role and person will not merge. Turner has posited that if a role is inconsistent with other roles the person has played, for example, faculty vis-a-vis administrator, and is short-lived, for example, "acting/interim," the individual will not identify with that role. Turner further proposed that the fact that the role is known to be temporary will impact upon the manner in which others perceive the actor.

A constant effort to respond to changing needs and views can be advantageous especially for leadership in transition. Major shifts in policies and procedures mutually planned among administration and faculty create a climate of acceptance which allows for a smooth transition. Tucker (1984) comments that no administrator can assume that acceptance and support for change will continue without continued efforts to listen to issues and concerns of faculty and staff.

Tucker (1984) observed that it is important to understand fully and quickly the academic environment of the school, the individuals who make up the faculty and administrative staff, the views and opinions of individuals inside and outside the school, the mechanisms for decision making, and the political environment that exists. In addition, there is a need to understand the potential, the values, and the limitations of the resources to accomplish the goals of the school. According to Whetten and Cameron (1985), one of the principles of effective administration is that the administrators understand and respect the indigenous campus culture. Norms built over time are not easily modified. In other words, the culture of the school and university, as well as the nature of academic units, is essential knowledge. Although a full understanding of the culture of a particular school may take several years, it is essential to implement strategies that increase the information base concerning this culture. Moreover, when an administrator comes from outside the ranks of organizational members, it is especially 
important to win the trust and loyalty of the community by embracing their norms and values. In addition, an understanding of the political climate of academic units is instructional (Whetten and Cameron, 1985).

Hershey and Blanchard (1982) suggest that no one can implement change successfully without understanding principles of planned change, including the natural response of individuals to change. The unique nature of the academic department, as well as the significant responsibilities of faculty members in decision making, must be appreciated. They observed that the degree of experience and willingness to assume responsibility on the part of members of a group should dictate the strategies to be used to propose change.

McCorkel and Archibald (1982) conclude that resistance to change of any kind is universal, but because of the "diffuse nature of academic government, faculty members in higher education have particular opportunity and a right to resist change" (p. 203). Faculty, more than others, approve of changes they themselves create. Change that is forced on faculty is resisted strongly. Resistance to change can take many forms. It can be direct or by tactics that delay decisions such as endless debate over minor points. Thus, involving faculty members in the planning, as well as the assessment, for change process is more essential than in other types of organizations. The best approach is one that "increases creativity rather than constraint, continuity rather than crisis, initiative rather than conformity, achievement rather than protocol" (Tucker, 1984, p. 17).

Ostensibly, the impact a dean may have on the parent institution and the functioning of the respective unit depends in large measure on a clear comprehension of the organizational dynamics operative within the parent institutions. This knowledge allows for choices in important and long-range decisions and for the structuring of effective communication within the entire organization. Although the immediate interactions with members at all levels is 
important, it is in the long-range decisions that the effects of leadership and its consequent power are most significant (Miles, 1975).

Although theoretical perspectives are a concern related to organizational tasks, and individual leaderships are gender neutral, the majority of leadership style studies have been done by men to measure leadership behaviors of male executives. In many instances, the results were then generalized to include women. Perhaps the appointment of women in administrative positions in business, education, and industry is too recent a phenomenon to command a leadership style research perspective of their own (French, 1985).

The purpose of this study on academic leadership is to investigate and summarize models in academic administration and the dean's exercise of power and leadership. The study will attempt to advance the study of academic leadership by examining models and to determine how a particular model may hinder or help the dean to fulfill the administrative role.

\section{ACADEMIC ADMINISTRATIVE MODELS}

In an enlightened study, Miles (1975) indicated three basic forms of organizational designs which he identifies as:

1. Traditional, which is essentially pyramidal in structure implying that finally decisions are made at the top;

2. Human relations, which differs from the traditional model with respect to acknowledging or emphasizing the effect of interpersonal behavior among individuals; and recognizing that the interaction among individuals has a direct effect on the group performance; and

3. Human resources model, which is based on the concept that people do not normally realize their full potential of self-direction and self- 
control in jobs, and that the manager must develop an atmosphere which encourages decision making at all levels. (pp. 34-43, 100)

This emphasis on self fulfillment is the key to the human resources model which sets it apart from the human relations model.

Herzberg's Motivation-Hygiene Theory is an example of the human resources model. It is a two-factor theory based upon the concept of good and bad feelings labeled as satisfiers, or motivators, and dissatisfiers, or hygiene factors, respectively (Albers, 1974, pp. 24-25, 503-504).

A major danger in the traditional model allegedly is the centralization of power to the extent that the attitude of the leader is condescending. This may lead to dissatisfaction among subordinates, low self-esteem and can readily become a subversive element. A spirit of cooperation apparently is lacking; hence, the functioning of the group becomes task oriented with little regard for the underlying objectives.

In the human relations model, the social environment becomes a very important factor because the movement toward team effort may be viewed as an important component. The atmosphere should be relaxed and a certain kind of camaraderie can probably develop. Hence, members of the group are more supportive to each other and recognize the leader as a member of the group with special functions.

Moreover, the atmosphere creates a motivational factor which can possibly result in the accomplishment of tasks readily and enthusiastically. Perhaps the most potent force for successful performance is the satisfaction derived from discovering the latent abilities of the individual. Arguably, the interdependence which develops established a communication environment which is open, free, and accepting. Hence, the individual's value to the group effort can be enhanced and underscores the worth of each contribution to the total effort. 
In the traditional model, the sphere of influence of the leader permeates the entire group. If this model is followed implicitly, the ability of a counteracting force to develop within the group is minimal. Yet, it is precisely this type of climate which nurtures counter-forces, particularly if job dissatisfaction reaches a critical low (Stogdill, 1974). With task accomplishment as the exclusive goal, this type model is most effective; however, if the task is related to personal interactions, even peripherally, the traditional model will impede success of the endeavor.

The human relations model relieves the leader of very little power. The manner in which this power is expressed or realized becomes a function of the degree of acceptance of the leader by the group. As the leader's acceptance by the group improves, the leader is more closely associated with the group. This can be disadvantageous when job performance of any member becomes unsatisfactory because the leader may be held equally responsible.

The human resources model allows the leader to develop a different kind of power which ultimately enhances the sphere of influence. This will have far-reaching effects by influencing the personal life and achievements of each member of the group, conceivably a most beneficial outcome.

Leadership effectiveness in the traditional model is reserved for the few, particularly because the nature of the relationship between leader and group requires a personality that can function in an environment that is essentially isolationist. Group loyalty is not characteristic, and the major concern of the individual member is to function satisfactorily enough to reap the rewards of the effort.

The human relations model provides a closer relationship between leader and group. Although the manager is still responsible for the major portion of planning and controlling activities, the added dimension of concern for individual 
desires makes the leader more vulnerable to personal reactions from workers to the work situation.

With the human resources model, the leader's role becomes more complex, more demanding, and more diversified. A higher level of performance results from the development of individual creative ability. This effects a greater degree of selfsatisfaction and self-actualization which esteems the leader to the group members and nurtures a spirit of identification to the group effort for all members. The need for closer interpersonal communication between worker and leader fosters a spirit of stability. Because the organizational unit becomes more self-directed and more flexible, the concept of change loses its threat and promotes the individuals adaptability (Miles, 1975).

The management theory, which imparts to the structure its particular form, will determine the communication system that exists within an organization. If communication is recognized as a process in which the message to be imparted acts as a link between the sender and the recipient, its importance as a persuasively powerful tool can be readily understood (Culbert and Conrad, 1970). The degree to which the art is mastered enhances the sender's ability to influence other person's actions, attitudes, and values (Applebaum, 1974). This complex dynamic process is affected by the characteristics of both sender and audience. As the situation changes, the flow and effectiveness of communication vacillates; therefore, the group structure becomes important and the role of the leader within that structure is of utmost importance (Applebaum, 1974).

\section{POWER}

Power has fascinated people from the beginning of history. This interest has been reflected in the surprisingly large amount of world literature that incorporates power as its central theme. Historically, power was viewed as a personal attribute, but more recently it has come to be considered a social phenomenon. Power generally is viewed as inseparable from interpersonal 
relationships, and therefore, a property of social relationships or small groups (Jacobson, 1972).

Power, among its definitions, is defined by Webster as "the possession of control, authority, or influence over others." Two interrelated constituents integral to power, according to Burns (1978), are motive and resource. He views leadership as a "special form of power," hence, "to understand the nature of leadership requires understanding of the essence of power" (pp. 2-5, 12). Stogdill (1974) recognizes major sources of power as expertness, legitimation, coercion, reward, and reference; hence, the person who is identified as an expert readily gains agreement from a group. This is also true of the individual whose role coincides with the expectations of the group, and who is elected to a position rather than the one who acquires position by force or emergence.

In a power situation, the holder of power has the advantage; yet, the group is able to disperse or weaken that power through the use of countermeasures. Peers interacting with influential group members whose values and goals differ from those of the leader can infringe on the extent of power held by the leader (Stogdill, 1974).

Position power has been widely tested as a component of the contingency (Least Preferred Co-Worker Scale) model of Fiedler (1971). In a study designed by Hunt (1967), three different organizations including a large physical science research laboratory, a chain of supermarkets, and a heavy machinery plant formed the sample. The findings indicated that the position of power of all managers and foremen was judged to be high. The basis of position power is attributed to a legitimate right through appointment or election to influence the performance of others in the organization (Fiedler, Chemer and Mahar, 1977). One major asset of power is position; to increase the status and authority of a position is to increase the legitimate base (Langford, 1981). 
An insightful study, conducted by Nealy and Shiflett (1969), attempted to induce a change of situational favorability from high position power to low position power. This was a simulated situation where the leader was instructed to play the role of leaders with both high and low position power. The position power in these two groups varied according to the power assigned by the investigator. The findings of this study was supported and explained by Fiedler, Chemers, and Mahar (1977) who wrote that people in power like to see themselves as being concerned with the comfort, well-being, status and contributions of others. The findings were further explained by the fact that followers do not always perceive the same qualities in leaders as leaders see in themselves.

\section{LEADERSHIP}

Studies of leadership styles, according to Dressler (1980), focused on what the leader did and how he performed generally agreed upon leadership functions. Style was further defined as a characteristic manner of performance. The most familiar of the styles used by higher education administrators is that of an amalgamation of initiating structure and consideration style. These two styles appear to have emerged from the work that was begun by Hemphill in the 1940's and were further developed by the staff of Ohio State University (Stogdill, 1963). It was subsequently found through empirical research that there was a large number of hypothesized dimensions of leadership behavior that could be reduced to two clearly defined styles. Fleishman (1953) and Halpin and Winer (1957) named these styles "Initiating Structure" and "Consideration." Initiating Structure Style was characterized by focus on task behaviors and a clear definition of what was expected by the actor. Consideration Style was considered interpersonal in nature. Administrators who used the Consideration Style valued the comfort, well-being, status, and contributions of their followers (Stogdill, 1963). These styles were not conflicting, but were judged to be separate and distinct. Neither was judged to be good or bad or right or wrong (Hoy and Miskel,
1978 ). 
Hoy and Miskel (1978) reported two education administration studies using the Leader Behavior Description Questionnaire in schools. One research study was conducted by Kuntz and Hoy (1974) using high school principals in New Jersey. The study focused on the leadership style of the principals and the "zone of acceptance" on the part of faculty of the leadership style of the principal. The findings revealed that consideration was related to a subordinate's satisfaction both with work and the leader. Further findings supported the conclusion that Consideration Style had the most positive effect on the reported satisfaction of a subordinate with his/her work in stressful situations.

A few studies in non-academic settings suggested possible relationships between the experience level of the group and leadership behavior. Hershey and Blanchard (1982) proposed a curvilinear relationship between group maturity and the two dimensions of leadership which they labeled task behavior and relationship behavior. Specifically, immature followers need more task behavior; more mature followers need less task and more relationship behavior; and the most mature followers need less of both task and relationship behavior. Bass (1960) specified that Initiating Structure (task orientation) was effective for new employees but not for seasoned employees. Kerr, Schrieshiem, Murphy, and Stogdill (1974) theorized from research that the less subordinates need information, the lower their tolerance for Initiating Structure. Badin (1974) found a negative relationship between Initiating Structure and group effectiveness for seasoned manufacturing employees.

Another study examined the "Ideal" leadership behavior of the dean on the two dimensions of Initiating Structure and Consideration as measured by the Leader Behavior Description Questionnaire and to determine the degree to which certain specified idiosyncratic characteristics of deans and faculty members relate to those perceptions. It was concluded that deans and faculty have similar expectations regarding behavior and qualities of deans. They are in agreement that the "ideal" dean should show consideration of the needs of subordinates, while 
also paying attention to organizational needs for task accomplishment (Somboon, 1984).

Many studies of academic leadership have utilized the Leader Behavior Description Questionnaire XII (LBDQXII) developed by Hemphill (1950). This instrument measures the task-oriented and the person-oriented behavior of leaders. It has a 10-item scale for Consideration (person-oriented behavior) and a 10-item scale for Initiating Structure (task-oriented behavior). Each stem describes a leadership act and a set of frequency adjectives for the respondent to indicate how often the leader engages in that behavior (Yukl, 1970). Hemphill (1955) used this instrument to study the leadership of academic department heads and found that administrative competency was related to Consideration and Initiation of Structure. (See postscript p. 37 for a commentary on the LBDQ).

In a profound exploration, Stogdill (1974) reported a number of additional studies supporting Hemphill's findings. There were many studies related to academic administrators: Luckie (1963), Lindemuth (1969), Flocco (1969), Hunter (1959), Charters (1964), Dawson (1970), and Dawson et al. (1972). In these and other studies, superiors' and subordinates' descriptions of Consideration and Initiation of Structure were related to leader effectiveness ratings.

Some of the more important findings in the Stogdill (1974) review were the studies by Greenfield and Andrews (1971) which showed that the Consideration and Initiation of Structure behaviors of teachers were significantly related to the achievement scores of their students. A related finding by Keller and Andrews (1963), and by Hood (1963), was that the leader behavior of second-level leaders was also significantly related to test achievement of followers. 


\section{From these findings, Stogdill concluded:}

...the significance of consideration and structure is to be explained, not in terms of leadership, but in terms of followership. The two patterns of behavior emerge as important, not because they are exhibited by the leader, but because they produce differential effects on the behavior and expectations of followers. (p. 141)

In a scholarly investigation, Spotts (1974) divided research studies into four classifications: trait, situational, functional, and interactionistic. Spotts noted that early studies utilized the trait oriented approach and sought to discover how leaders differed from followers. Some studies found that leaders were bigger, brighter and better adjusted than followers but leaders did not differ to a marked degree from followers. Others found that leaders were more enthusiastic, friendly, decisive, knowledgeable, imaginative, and courageous. But rarely did any two tests of traits agree on the essential characteristics to be found in leaders.

Studies exercising the situational approach assume that traits and skills of a "good" leader will vary from situation to situation. These studies show that leadership varies with the needs of the situation.

Moreover, Spotts (1974) observed that the functional approach turns the focus away from the individual as leader, to the study of the group. Here, interest is on group survival and attainment of goals. These studies reveal that the behavior of leaders varies with the task at hand and, further, that this leader behavior "...can have marked effects upon group member performance." (p. 18)

Finally, Spotts found the interactionistic studies unique in that they stress the quality of leader-subordinate interaction and its effect on productivity, morale, and other goals. This approach uses field studies rather than contrived laboratory settings in order to observe interaction. 
In an analogous learned study, Yukl (1981) also summarized the leadership research into four classifications. He noted the trait approach and the situational approach identified by Spots, but added two slightly different dimensions. Yukl identified a behavior approach which is similar to Spott's functional dimension in that it focuses on leader behavior. The difference seems to be that the behavior approach seeks to identify differences in behavior patterns between effective and ineffective leaders. He also identified the power-influence approach to the study of leadership which seeks to explain leader effectiveness in terms of the kinds of power available to the leader and how this power is exercised. This classification is similar to Stogdill's classification of leadership studies on power relationship.

In reviewing behavioral research relative to leadership, Yukl was particularly critical of the use of the questionnaire scales to measure Initiating Structure and Consideration in order to determine leadership effectiveness. These studies, he states, have produced inconsistent results except for the finding that "...subordinates are usually more satisfied with a leader who is highly considerate, which is hardly a momentous discovery" (p. 129). He does express some confidence in recent developments aimed at improving this approach using a behavior taxonomy to reconcile diverse findings.

According to Yukl, the situational approach involves complex theories which are imprecisely formulated, and therefore difficult to test. These studies require the use of comparative field studies, longitudinal field studies, and laboratory experiments in order to determine the situational variables as well as the consequences of leader behavior in different situations.

After citing the shortcomings of leadership research to date, Yukl summarizes his findings by stating:

The many hundreds of studies on leadership behavior have provided only limited insight into what leaders do and why they are or are not effective. ...improvements are needed in the conceptualization and measurement of leadership behavior. (p. 286) 
Not withstanding that one might agree with Yukl that improvements are needed, we are still left with the knowledge that an impressive body of research related to leadership has been amassed through the years; and some of this research has given particular attention to academic leadership.

Thus, leadership has many definitions. Stogdill (1974) sees it as a "process of influencing group activities toward goal setting and goal achievement" (p.141). Despite its many definitions, Burns (1978) reflects that "leadership is one of the most observed and least understood phenomena of earth" (pp. 18-19). According to him, in the Classical and Middle Ages, this problem did not exist. During those times, concepts of leadership were carefully examined and recognized. Today, despite a vast reservoir of data and theories, no central concept of leadership is recognized.

\section{DISCUSSION}

As a result of the investigation into the role of the academic dean and theories of leadership, it is probably safe to assume that any one of the academic administrative models presented does not exist in pure form. Rather, the principles of one system predominate with a reflection of other systems becoming apparent in a given situation.

In an institution where governance can best be classified as following the traditional model, the ability of the dean to arrive at immediate decisions in the day-to-day activities or to institute minor changes promptly is seriously hampered. Emergency situations which tend to arise, especially in conjunction with today's depressed economy and lack of financial resources, become exceedingly stressful. Independent action is stifled and unless the chief academic officer is cognizant of the nature of change and the faculty, the potential for a high degree of effective decision-making is thwarted. 
The human relations model ameliorates some of these effects by promoting a degree of communication horizontally and by placing the dean in a role which contributes to this communication process. The ingredient that is missing is the free exchange vertically which often translates into lack of support from the higher echelon. The dean's position lacks credibility; hence, the sense of power is lacking and effective leadership suffers.

The human resources model best promotes a unified effort toward excellence in leadership and faculty alike by encouraging the continued development of all persons within the institution. The open communication fostered in this model permits an active dean and faculty evaluation system which encourages activity toward self-improvement and greater management and teaching effectiveness. Major shifts in policies and procedures mutually planned among administration and faculty create a climate of acceptance which allows for a smooth transition from the old to the new.

As a final note, after an extensive review of the literature, some additional perspectives on the deanship in American higher education are in order. Academic leadership strategies and techniques tend to be evolutionary. They are continually adapted to meet current problems and to take advantage of perceived opportunities facing the institution. Unfortunately, that which was successful in managing the affairs of a growing or economically secure institution tends not to serve as well when the institution enters a period of decline. Poor resource allocation decisions during a period of growth tend to be more easily concealed or corrected than in a period of decline.

In spite of the increasing uncertainty that has accompanied higher education through the eighties and into the nineties, the pace of change in the leadership and management in higher education has been measured for a variety of reasons. Many higher education administrators initially, and some for perhaps too long, have viewed the demographic and economic adversities confronting their institutions as aberrations in the long-term health of their institutions. 
Moreover, many institutions had sufficient slack resources to accommodate lower funding and enrollment levels.

The process was further slowed down by the fact that the gloom and doom forecast by many simply did not arrive on schedule or with the projected impact. Another contributing factor was higher education's traditional de-emphasis of academic administrative training. Adequate preparation for administrative responsibility has hinged more on scholarship within one's own discipline and appropriate political acumen. Administrative skills were more appropriately developed on the job.

Consequently, academic leaders continued to concentrate on acquiring new resources rather than enhance their efforts at analysis and identifying better ways of using existing resources. Lastly, it takes some amount of time for those institutions and deans who are willing to experiment and try new approaches to identify what will work and to modify or discard that which does not work.

Conclusively, there are probably as many definitions of leadership in the literature as there are authors who write on the subject. Perhaps the most that one can say about leadership is that it involves a thorough understanding of the concept of motivation, the ability to function within a complex communications network, and the selection of a leadership style that produces an effective interaction of the situation, the leader, and the follower. In response to the recurrent question of whether the administrator is a manager or a leader, Zaleznik (1977) suggests that leaders are active instead of reactive; they shape ideas instead of responding to them. The net result of a leader's influence in altering moods, evoking images and expectation, and in establishing specific desires and objectives is to change the way people think about what is desirable, possible, and necessary. Leaders work to develop fresh approaches to longstanding problems and to open issues for new options. 
Thus, leadership style, an elusive but fascinating topic that has been heavily studied became an even more fascinating topic for higher education administrators. Leadership style focuses on what a leader does and how he behaves in the performance of leadership functions (Dressler, 1980). Research derived from the behavioral theories of styles of leadership were conducted by Bales (1958). His findings concluded that there are two major functions leaders can perform: accomplishing the task, and satisfying the needs of group members. An effective leader may fill one or both roles (Dressler, 1980).

In sum, it would appear from the foregoing exposition on academic leadership that the dean's sense of timing and sensitivity to the interaction among individuals plays a leading role in determining the degree of the dean's power within the institution; and evidently, the extent to which individuals are urged and assisted to realize their potential is a measure of effective leadership.

\section{POSTSCRIPT}

The original Leader Behavior Description Questionnaire (LBDQ) was used to measure the leader's self-perceived leadership behavior (Hemphill, 1950). The LBDQ was further developed by Hemphill and Coons (1957) and later refined by Halpin and Winer (1957) as part of the Ohio State Leadership Studies. The LBDQ is regarded as the most widely used method for describing leader behaviors (Hoy and Miskel, 1982). Kerr, Schriesheim, Murphy, and Stogdill (1974) advocate the use of the LBDQ as a method of classifying leader behaviors. They describe the instrument as "theoretically meaningful"; "factor-analytically determined"; "descriptive of behaviors which are readily identifiable"; "a common sense look .... which is appealing"; and used in numerous studies "of good quality" (p. 64). The LBDQ has been shown to have concurrent validity with the Supervisory Behavior Description Questionnaire and the LBDQXII (Schriesheim, House, and Kerr, 1976). Halpin (1957) reported a split-half reliability with SpearmanBrown correction of .92 for the Consideration dimension and .83 for the Initiating Structure dimension. 
For the present study on academic leadership and the role of the dean, leadership was defined as the behaviors of individuals as they direct the activities of their group toward goal-setting and goal achievement (Hemphill and Coons, 1957; Stogdill, 1959). However, the LBDQ measures the two dimensions of leadership: Consideration (relationship orientation) and Initiating Structure (task orientation). Consideration "refers to behavior indicative of friendship, mutual trust, respect, and warmth in the relationship between the leader and members of the staff" (Halpin, 1966, p. 66). Initiating Structure "refers to the leader's behavior in delineating the relationship between himself and members of the work-group, and in endeavoring to establish well-defined patterns of organization, channels of communication, and methods of procedure" (Halpin, 1966, p. 86).

One limitation of the LBDQ is that leadership is measured on the basis of the leader's self-perceptions. It has been shown that the leader's perceptions are not always the same as perceptions of either their superordinates or subordinators. Perhaps some other objective measure of leadership behavior would be more accurate than the LBDQ.

Further research could also determine if there is an overall leadership style of an institution which reflects more than just one individual within the administrative structure. In this context, it would be interesting to see if styles determined by factoring in the leadership behaviors of presidents, provosts, deans and their associates/assistants might differ according to the organizational characteristics. Although, it must be remembered that organizational characteristics are only one part of the framework used to describe important variables in the study of leadership. Other essential variables relate to leader characteristics, follower characteristics, and other environmental or contextual variables (McGregor, 1976). 


\section{ACADEMIC LEADERSHIP AND STRATEGIC PLANNING}

\section{INTRODUCTION}

Arguably, the 1990's may prove to be one of the most difficult decades for higher education. Consequently, it is important to have a commonly accepted, disciplined way of thinking about the application of limited resources to complicated complex problems. Perhaps, strategic planning would provide that common discipline in thinking about how to face those problems for academic leaders and development officers, since they must work together to secure the financial stability of the academy.

Lamentably, academic leaders are not generally prepared to cope with or to manage effectively conditions of educational instability. According to Boulding (1975):

We are very ill-equipped for the management of decline. For several generations, a considerable proportion of the human race, and the United States in particular, has enjoyed growth in almost all aspects of social life. All our institutions and ways of thinking have survived because they were well adapted to an age of rapid growth. If this age is now coming to an end, large adjustments will have to be made in our ways of thinking, in our habits and standards of decision making, and perhaps even in our institutions.

Boulding goes on to state:

Present educational administrators have grown up in the rapid growth and have been selected presumably because they are well adjusted to growth and capable of dealing with it. Perhaps the most serious immediate problem facing education and especially higher education, is that many skills that were highly desirable during the last 30 years may no longer be needed in the next 30 years. 
One of education's first priorities, therefore, should be to develop a new generation of academic administrators who are skilled in the process of adjusting to decline. Yet we know so little about decline that we are not even sure what these skills are. (pp. 8-9)

Regarding environmental change, economic down-turn and retrenchment, Scott (1974) noted:

What politician, public administrator, or business executive in practice supports overtly to his constituents policies of economic contraction, reduction of agency services, or stabilization of sales volume and corporate earnings? How many university courses are offered in "How to Shrink a Business"? How frequently do articles appear in the professional literature about management strategies of organizational stability or decay? These things seldom happen because they reflect values that are foreign to American expectations and, thereby, are foreign to the mainstream of management thought and practice. ( $p$. 243)

Against this background, this study will endeavor to address a recognized need: enhancement of strategic planning in academic management. The purpose of this brief study is to investigate and summarize concepts and perspectives on strategic planning and management in American higher education as identified in the relevant literature.

Hence, an operational definition of strategy and of management for this study is in order. According to Myran (1983):

A strategy is a definite course of action that is adopted by college leadership in order to shape the character, scope, and direction of the college. Strategic management is a future-creating process that guides and integrates the various strategies and decisions of the college in such a way that the college as a whole is positioned favorably in relation to emerging opportunities and threats in the external environment. (pp. 10-11) 
An assumption of this study is that the mission of American higher education is to benefit society by educating present and future generations of citizens. Effectively fulfilling this mission is the goal of all colleges and universities. However, attempting to establish differential statements of mission for each institution is difficult. As observed by Millett (1984):

In our study, we found a great deal of controversy about mission statements, but we did not find a single set of mission statements that adequately differentiated institutional purposes and programs. (p. 149)

Moreover, mission statements change over time, influenced by employment patterns, economic factors, and the political climate. Millett (1984) further noted:

In the era of substantial expansion, roughly from 1960 to 1975 , the emphasis was upon building new campuses that would be geographically dispersed throughout the state, expanding existing campuses, adding new capital facilities, and increasing faculty salaries. In the years after 1975, the issues were duplication of facilities and programs, the disproportion in size of institutions, the possibility of merging or even of closing some institutions, and the containment of cost increases. (p. 146)

The literature suggests that while such organizational deficiencies were manageable in an era of rapid growth and abundant resources, the present environment dictates a more deliberate harmony of form and function. Hence, higher education must be environmentally sensitive, mission focused, and outcome oriented to ensure rapid response to changes that can adversely affect their existence. The literature goes on to imply that a basic assumption, when engaged in an extensive strategic planning activity, is that change is continuous and inevitable. Moreover, that an institution that was environmentally focused and outcome oriented, rather than internally focused and functions oriented, and that adapted continuously, would fulfill its mission. 
Conceivably, strategic planning is an approach that applies planning principles in decision making. In recent years, according to the literature, higher education has taken note of this concept and has begun to apply strategic planning principles within the academy. Apparently, strategic planning is an important process not only in business but in educational institutions as well. Although a large number of studies focuses on strategic planning in business, there are many ideas and practices that can be adapted to institutions of higher education. According to Ebenstein (1981), a carefully planned and implemented strategic planning program can be extremely important in better management and production and in improving the operational and cost control of an organization.

Thus far, it would appear from the preceding commentary on strategic planning and management that the success of American universities and colleges may be measured by the way in which they sense and creatively respond to environmental changes affecting the mission. Perhaps the failure to respond to environmental changes and, hence, to fulfill their mission, defines the problem confronting some American institutions of higher education.

Rowland (1978) suggests that "the success of an institutional advancement program in colleges and universities rests largely on effective management" ( $p$. 531). Therefore, a prime assumption of this study is that strategic planning, as a management tool, is directed toward improving organizational performance.

\section{STRATEGIC PLANNING IN ACADEMIC MANAGEMENT}

In a well-researched study, George Keller (1983) describes the problems that confront American higher education in the eighties and nineties as well as some of the effective strategies that individual colleges and universities, faced with times of adversity, have adopted. The main focus of Keller's study is the application of strategic-planning techniques to institutions of higher education. He regards such planning as a constantly emerging process designed to take control of an organization's strengths - including traditions and resources - and its 
opportunities while being fully cognizant of external forces, predictable future shifts, and market considerations.

Keller (1983) indicates that strategic planning can not be clearly defined, but he indicates that, among other things, strategic planning is:

- Not the production of a blueprint, but rather a process of getting key people thinking innovatively with the future in mind;

- Not a set of platitudes, but rather the formulation of succinctly stated operational aims;

- Not a collection of departmental plans, compiled and edited, but rather a plan for the whole institution in relations to its long-term stature and excellence;

- Not a substitution of numbers for important intangibles, but rather the introduction of these to sharpen judgments, analyses, and decisions; and

- Not an attempt to outwit the future, but rather an effort to make this year's decisions more intelligent by looking toward the probable future and coupling decisions to an overall institutional strategy. (pp. 140142)

In other words, strategic planning is centered on an analysis of the organization and of the external environment. Also, according to Keller, strategic planning incorporates six interdependent steps in its operational definition. First, the role of the institution in the environment must be assessed. Second, strategic planning must monitor the external environment more effectively by improving data collection. Third, planning must identify the institution's strengths and advantages and capitalize on its unique aspects. Fourth, strategic planning embodies an orientation toward action. Fifth, strategic planning is participatory and requires debate. Finally, the ultimate goal is long-term viability and excellence of the institution. 
Keller believes, nevertheless, that "academic strategies should 'unfold,' bend the established forms slowly," and use existing offices as much as possible. $\mathrm{He}$ emphasizes, moreover, that although speed and decisiveness are often necessary, academic strategies should not violate the essential values or mission of the institution. In fact, Keller argues strenuously that the issue of mission, of knowing what an institution is and can legitimately strive to be, must be addressed before any strategic planning can be undertaken.

In building upon Keller's work, Green and Monical (1985) believe that strategic planning emphasizes the future direction of an institution. Successful institutions have a vision of the future and a strategy for realizing that vision. To help ensure success, not only strategic planning but also strategic thinking and management must be in place.

According to Green and Monical (1985):

Strategic planning poses four fundamental questions: Where have we been and where are we now? Where will we be in the future by following our present course? Where do we want to be? How will we get there? The successful performance of an organization relates directly to effective planning, decision making, and execution. An organization that determines where it plans to go, what it plans to do, and how it plans to do it, can make better decisions, more effectively manage resources and operations, and adjust more readily to change. (p. 49)

Kotler (1982) notes that strategic planning is "the managerial process of developing and maintaining a strategic fit between the organization's goals and resources and its changing marketing opportunities" (p. 83). Morrison and Cope (1985), in comparing strategic planning to long-range planning, state that strategic planning is usually characterized as "outside-in" planning and places emphasis on the environment. 
In a revealing study, Techniques of Scenario Planning. Chandler and Cockle (1982), create duplicate models to study the consequence and merits of alternative courses of action in corporate planning. The study contrives coherent pictures of various possible events in the environment and tests them and their impact on the business situation through linked models. Hence, the main purpose of scenario planning is to provide a test situation for the financial and business structure within a particular time frame. The models presented in the study provide some insight into the various aspects of scenario planning in the corporate structure.

Based on Chandler and Cockle's study, it can be inferred and argued that at a minimum, academic institutes of higher education should consider three alternative views of the future:

- An optimistic scenario;

- A most likely future scenario; and

- A pessimistic scenario.

These scenarios should be carefully researched, concisely written, and completely rewritten every three or four years, depending on how rapidly the external environment is evolving. Additionally, each scenario or future needs to address major environmental trends over the upcoming five-year period. These trends include:

- Cultural and social changes;

- Demographic patterns;

- Economic circumstances;

- Political circumstances;

- Technological changes; and

- Considering in depth what the competition is doing and is likely to do, particularly, in regards to recruitment of students and faculty, fund raising and research.

The review of the literature has shown that planning for change can be an extremely difficult process, one in which competing groups with very different 
agendas vie for limited resources. It has been said that a planning program needs to reflect the environment, requirements, and opportunities unique to each institution. The planning program must also be tailored to existing organizational structures and to the institutional culture in which change is planned. Arguably, success depends largely upon the quality and commitment of academic leadership at all levels and the degree to which resources are identified, committed, and used to support the process.

Hipps (1982), in a well-versed study, describes a generalized model for change that can perhaps be used as the basis for the strategic planning process. Hipps lists eight elements that he believes essential to any institution attempting to effect organizational change (pp. 115-130):

- Definition of organizational mission;

- Top administrative support;

- Leadership development;

- Comprehensive change program;

- Participation;

- Emphasis on communication;

- Emphasis on process; and

. Merging of individual and institutional goals.

In an insightful study, McCorkle and Archibald (1982) state that in the contemporary environment, the management process must distinguish between those functions which are fundamental to the institution and those which are merely desirable. In order to expand or enhance fundamental functions, the lower priority activities must be phased down or eliminated. Such an approach is relatively simple to state and most difficult to implement. As McCorkle and Archibald point out, the least defensible activity tends to produce the least amount of dollars for reallocation. Moreover, every defensible activity has one or more constituencies ready to defend it against all assaults. Thus, the decisionmaking process employed to establish programmatic priorities must be "...rational, self-conscious, open and deliberate..." (p. 3). 
According to McCorkle and Archibald (1982), the management process necessitated by the continuing uncertainty facing American higher education institutions has three primary components:

. Planning;

. Resource management; and

- Assessment of results.

The management process is closed and is characterized as dynamic, integrated and iterative. The planning goals should be clearly stated and widely understood. Such goals serve to direct policy and subsequent resource allocation decisions. The latter ensure that the plans are indeed implemented. McCorkle and Archibald posit that the process should employ qualitative and quantitative criteria to assess the institution's success in fulfilling its planning goals. These data should be used to continually fine-tune the planning process and subsequent resource allocation decisions.

The proposed process links strategic institutional planning and the development of the annual budget. It does this by converting long-term institutional objectives and strategies into definite multi-year goals and program plans. In order to do so it must provide an institutional environment that facilitates change and growth in spite of uncertainty. The process seeks to assist faculty and administrators in identifying the "...new realities and to turn uncertainty into opportunity" (p. 13). The process leads to a change of roles for the institution's professional planning staff. It prompts the movement of planning decisions to higher administrative levels; planners tend to become somewhat more isolated from the budget-making process. McCorkle and Archibald state that planners "...now analyze post-expenditure patterns, help project future income levels and identify important environmental forces early in planning" (p. 17). Although they state that there is emphasis on giving academic management long-term commitment of resource, as a means of achieving quality, this goal has to be counter-balanced with the need for greater institutional flexibility in resource management. This flexibility is in part provided through the use of program review procedures. These periodic reviews aid chief administrative officers in 
establishing priorities for program expansion, phasing down or elimination. The funds freed provide for the subsequent resource allocation, which is posited as the chief administrative officer's most powerful management tool and means of effecting institutional change without the aid of additional resources. In sum, this study provides a useful and thought-provoking description of an approach to linking strategic planning and operating budget functions.

Finally, the matter of decision making based on strategic planning in colleges and universities has continued to concern both participants and observers of higher education. This issue has assumed new importance in recent years as institutions of higher education have become more complex organizations with many more, often conflicting, demands being placed upon them by various elements of society. Furthermore, like other large organizations in today's society, institutions of higher education are compelled to comply with the many government (principally federal) laws and regulations which have been passed in recent years to promote and ensure social justice and the common welfare for all citizens. In sum, American colleges and universities are quite different from the quiet college communities of some years ago with their very focused interests and narrow constituencies; accordingly, the methods of decision making, of deciding how the institution will commit its resources, have had to change in order to meet the challenges now faced by academe.

Thus, in view of the fact that much of higher education in the nineties will face declines in resources and an unstable economy, it will be increasingly important that academic leaders and those in development and planning seek a common way of addressing these problems, which leaves out no essential constituency, in order to support institutional renewal.

\section{DISCUSSION}

According to Webster, the word strategy evolved from the Greek word "strategos" which means "general," and literally describes a military command exercised to 
meet the enemy in combat under advantageous conditions. Today, a strategy more commonly describes the art of devising and implementing plans toward a goal. Strategic planning is an approach that applies planning principles in decision making and in contrast to long-range planning, strategic planning places special emphasis on the consideration of both the immediate and the extended environments in which the plan is executed. Strategic planning is characterized by ongoing flexibility and responsiveness. Also, there is the tendency to confuse strategic planning with forecasting; it has been said that forecasting represents a singular future whereas strategic planning represents getting the institution ready for several futures.

For George Keller (1983), an academic strategy would consider both the internal as well as the external environment including what the competition is up to. According to Keller:

In short, you need to know what your college or university can or can not do, and what it wants to do. Then you need to discern what it might do, and should do. Last, you need to decide what it will do. Your academic strategy, at least its more rational components, should exude from the compound of internal consideration. (p. 153)

Keller goes on to state that an academic strategy results from an effort to "serve your students better and position yourself more self-consciously in the complex network of 3,100 colleges and universities." (p. 159)

According to Keller, American higher education is going through a revolution and any college or university that hopes to shape its own destiny rather than await its fate will have to mount an aggressive effort to manage, to lead, and to govern. Passive administration will not suffice in an age where competition is keen among institutions of higher education. These institutions must develop "ways of bringing planning and organizational politics together and methods for uniting strategy formulation and strategy implementation" (p. 118). Colleges and universities have been characterized by their resistance to change limiting 
academic leaders to administration, as distinct from management. The result has been a generation of administrators reacting to crises rather than taking proactive measures to effectively control and/or avoid these crises. Academic leaders are encouraged to "shift the focus of their attention and energy gradually to the long-term interests of their institutions and their increasingly competitive and difficult environments" (p. 165). In other words, "the era of laissez-faire campus administration is over. The era of academic strategy has begun... Leadership is imperative." However, the operative distinction would be: to administer an institution is to make certain that things are done correctly; to manage one is to see that the right things are done.

Leadership is perhaps the most complex of elements in the administrative process. There are probably as many definitions of leadership in the literature as there are authors who write on the subject. Perhaps the most that one can say about leadership is that it involves a thorough understanding of the concept of motivation, the ability to function within a complex communication network, and the selection of a leadership style that produces an effective interaction of the situation, the leader, and the follower. The age old question of whether the administrator is a manager or a leader is explored by Zaleznik (1977). Leaders, according to Zaleznik, are active instead of reactive; they shape ideas instead of responding to them. The net result of a leader's influence in altering moods, evoking images and expectation, and in establishing specific desires and objectives is to change the way people think about what is desirable, possible, and necessary. Leaders work to develop fresh approaches to longstanding problems and to open issues for new options.

"Every organization needs to have a forcible champion of good management and planning," according to Keller (1983, p. 165); who advocates for an assertive form of "top down" executive direction that acknowledges, nonetheless, the need that "knowledge workers" have for "softer," more "open" styles of leadership and management. Moreover, Keller goes on to state that "more efforts at improvement and better planning collapse because of the lack of consistent 
advocacy by the top leadership and persistent monitoring of divisional plans than for any other reason." (p. 166)

Conceivably, as a result of the above brief exposition on strategic planning and management in academe, it can be argued that managerial strategies and techniques tend to be evolutionary. They should be continually adapted to meet current problems and to take advantage of perceived opportunities facing the institution. Unfortunately, that which was successful in managing the affairs of a growing or economically secure institution tend not to serve as well when the institution enters a period of decline. Poor resource allocation decisions during a period of growth tend to be more easily concealed or corrected than in a period of decline.

In spite of the increasing uncertainty that has accompanied higher education through the eighties and into the nineties, the pace of change in the management in higher education has been measured for a variety of reasons. Many higher education administrators initially, and some for perhaps too long, have viewed the demographics and economic adversities confronting their institutions as aberrations in the long-term health of their institutions. Moreover, many institutions had sufficient slack resources to accommodate lower funding and enrollment levels.

Who knows but that the process was further slowed down by the fact that the gloom and doom forecast by many simply did not arrive on schedule or with the projected impact. Perhaps, another contributing factor was higher education's traditional deemphasis of academic administrative training. Adequate preparation for managerial responsibility has hinged more on scholarship within one's own discipline and appropriate political acumen. Managerial skills were more appropriately developed on the job. Consequently, higher education managers continued to concentrate on acquiring new resources rather than enhance their efforts at analysis and identifying better ways of using existing resources. Finally, it takes some amount of time for those institutions and 
administrators who are willing to experiment and try new approaches to identify what will work and to modify or discard that which does not work.

Conclusively, because much of higher education in the next decade will face declines in resources and the number of potential students, it will be increasingly important that those in planning seek a common way of thinking about these problems which leaves out no essential constituency. In addition to declining enrollments, changing demographics, deteriorating facilities, smaller governmental appropriations and more competition for private dollars imply a different approach to the recruitment and retention of students and faculty, fund raising, and to the overall administration and governance of the academy. Conceivably, the need for strategic planning and data-based decision making is crucial if American higher education is to survive, compete, and progress in educating its students, contribute to the generation and transmission of new knowledge, and provide services to society. Moreover, the academic leader's inventory should include a firm grounding in administrative theory, academic leadership, governance, fiscal management, public relations, and strategies for fund raising. In an era of cost control and limited resources, academe is faced with balancing the need to cut costs and, therefore, programs on the one hand, and the need to generate more income on the other. The ability to prioritize and reallocate resources becomes significant, and this ability, arguably, depends for the most part on the quantity and quality of relevant data available for decision making. For as Rowe, et al (1985) noted succinctly:

Strategic planning is a process used to determine and evaluate alternatives for an organization to achieve its objectives and mission. It is a decision process that relates an organization's objectives, mission, and capabilities to the opportunities and threats in the environment. (p. 3)

Moreover, the need, inherent in the private higher education environment, to continually diversify the revenue base place special burdens on the institution's central administration. Hence, the institution should recognize a clear need to restructure itself to provide a sounder financial base that would allow greater 
flexibility in decision making to bring about the changes envisioned in the strategic plan.

However, strategic planning is never accomplished. Long before a plan is concluded: the plan is on its way to obsolescence. A changing environment ensures as much. Planning is a process that does not end. A strategic plan is not a document that can be prepared every three, four, or five years: it is a continuing task. And the process of planning is more valuable than the resulting plan because the process encourages the decision maker to consider environmental change and to debate the strategic options open to the institution, given the school's strengths and weaknesses. Thus, the ability to plan, think, and manage strategically including the ability to prioritize and reallocate resources, becomes pivotal in an era of cost control and limited resources. Arguably, strategic decisions are based on the best evidence available about the unforeseeable future.

In sum, Peter Drucker (1975) defines strategic planning as "a continuous process of making decisions in a systematic manner with the greatest knowledge of their future" (p. 3). In addition, strategic planning involves "organizing the efforts needed to carry out these decisions and measuring results through organized, systematic feedback" (p. 3). Ostensibly, a crucial goal for American higher education would be the establishment of a permanent strategic planning process that would permit universities and colleges to remain continuously adaptive within a changing environment. A university or college with no strategic plan, means that no one has given much thought to where the institution needs to head in the future. Furthermore, productive strategic planning will focus to a much greater degree on effectiveness than on efficiency. Obviously, it is more important to do the right things than to do things right.

As the case may be, strategic planning, however imperfect, is a rapidly improving art form and management tool for higher education. Academe should look at the alternative ways of meeting future needs and plan the most effective 
way to begin. It must attempt to estimate the future development of the institution and of society's requirements. The planning process should involve enough of the academic community and society's leaders, as well as members of the governing board, so that adequate consensus and clarity are achieved and should remain sufficiently flexible so that new directions that don't succeed can be phased out smoothly.

\section{ADVANCEMENT ACTIVITIES IN AMERICAN HIGHER EDUCATION}

In order to supplement the basic and often insufficient funds from tuition, present-day university and college leaders increasingly have been seeking support from governmental agencies (Trow, 1988). In 1985-1986, expenditures of all kinds on American colleges and universities were estimated to be over $\$ 102$ billion, an increase in current dollars of $32 \%$, and in constant dollars of $17 \%$ over $1981-1982$. This represents roughly $2.5 \%$ of the Gross National Product ("Higher Education is a U. S. Industry," 1986). Moreover, the spiraling cost of higher education, an economy encumbered with unbridled inflations, and the financial constraints which are placed on America's colleges and universities when governmental agencies diminish the amount of educational allotment can be clearly documented: Keller (1983), Leslie (1971), Bowen (1969), and Trow (1988).

Leslie (1971), suggested that the leveling off and consolidation of federal and state financial support may be accentuating the financial difficulty. As Howard R. Bowen (1969), former Claremont Graduate School President and Claremont University Center Chancellor noted:

Legislators do not look with favor on the extras that will make the difference between adequacy and excellence. The public institutions, which wish to strive for exceptional performances, are therefore forced to look to private sources for the funds needed to lift them above the common place or the mediocre. ( $p$. 1) 
Trow (1988, pp.13-23) comments upon the financial condition and trends in higher education finance. He writes:

One important and distinctive characteristic of American higher education is the diversity of its sources of support. This diversity of funding sources has large consequences for the autonomy of American colleges and universities and for their traditions of service to other institutions, both public and private, as well as for their finances. Taken in the aggregate, American colleges and universities get support from federal, state, and local governments, from private sources such as churches, business firms, foundations, and individuals, from students, in the form of tuition and fees, living expenses in halls of residences, food services, health services, and the like; and from their own endowments, as well as from the sales of their services to others.

\section{In terms of governmental support to higher education, Trow (1988) states clearly:}

Government at all levels together provide nearly half of all current revenues for American higher education, and that excludes federal aid given directly to students, which shows up, for the most part, as tuition and fees from the students. The federal government provides only about $13 \%$ of the support for higher education overall, and that includes its support for research and development in the universities, but excludes the aid it provides directly to students. State and local governments (mostly states) provide a third of all support for higher education. Students themselves provide another third, including federal aid they have received. The institutions themselves contribute about $15 \%$ from their own endowments and other sources. If we count federal aid to students as federal support to higher education, it increases the federal proportion to about $23 \%$ of total support and reduces the student contribution to about the same proportion. Another $6 \%$ is provided by individuals, foundations, and private business firms, in the form of gifts, grants, and contracts. 
These proportions, of course, differ between public and private colleges and universities, though it must be stressed that all American colleges and universities are supported by a mixture of public and private funds. For example, whereas in 1981-1982, public four-year colleges and universities got over $44 \%$ of their operating budgets from their state governments, the private institutions got less than $2 \%$ from state sources. (But note, private colleges received a slightly larger proportion of their support funds from the federal government than did the public institutions.) The other big difference lies in the importance of student's fees and payments directly to the institution for services: these account for less than a quarter of the revenues to public institutions, but about a half of the support for private institutions (Plisko, 1985, p. 114, Table 2.14). These proportions differ sharply among even finer categories of colleges and universities; for example, as between public research universities and public four-year colleges.

However, with governmental support of higher education, colleges and universities have faced unusual problems. Perhaps the greatest difficulty created by the government has been the encouragement and support of individual research projects. In effect, this has amounted to the government's funding individual scientific projects rather than investing in an educational process.

Trow concluded:

...the federal government has become a major source of support, both for university-based research and through student aid. Yet it still supplies less than a quarter of all support for American higher education. Moreover, the government's influence on the system has been further muted, precisely because that support has gone to individual scientists and students rather than directly to the institutions.

As pressure mounts upon American colleges and universities to improve their quality, schools of dentistry find themselves having to retrench in the name of quality and/or fiscal responsibility. It becomes important, therefore, for 
schools of dentistry to establish academic excellence, which arguably would include meaningful research, supported by a constant source of funding.

A successful fund raising program for American schools of dentistry requires time, effort, and effective planning and marketing. Arguably, the institution is looking for a sustainable contributions program that is achievable and rewarding.

This study will explore, however briefly, the assumption that school of dentistry deans are the central decision makers and strategists in fund raising. The dean has to establish specific goals and then make sure those goals are met by taking advantage of available marketing tools to turn strategic plans into action. A fundamental and incontrovertible responsibility of the dean is to assure the integrity of financial management and lead in raising the funds needed to fulfill the school's mission. To those ends, the dean should reassure the recruitment of competent development staff, encourage university involvement, and enlist and rally the active participation and support of alumni.

Furthermore, an additional primary assumption is that school of dentistry officials are increasingly involved in external affairs and much of a dean's time and effort is spent on interacting with various constituencies and other interested parties, such as governmental agencies, legislative bodies, and the public. Conceivably, good public relations is helpful if the institution is to realize its potential in student enrollment, student quality, and fund raising. However, even a prestigious institution is not immune by any means to the problems and issues that confront most professional health care schools. These notable institutions may not have to compete vigorously for enough enrollment, but they do have to compete for the very best students, the premier faculty, and certainly for contributions. Moreover, they may not have to worry about enrollment numbers, but they must be concerned with seeking merit scholars, quality faculty, and research grants that might go elsewhere. In these regards, they have a very definite marketing task and as with marketing, the relevance and value of strategic planning in schools of dentistry should be recognized. 
Marketing has been simply defined as providing customers with the goods and services they want or as Peter Drucker has said: "Marketing is the central dimension of business... there is only one valid definition of business purpose: to create a customer" (Drucker, 1975, p. 13).

Strategic planning is fundamentally a process for determining resource allocation and institutional emphasis and/or de-emphasis. The dental deans make decisions about economic resources - they allocate scarce resources among competing uses. Moreover, the schools of dentistry are affected by a changing environment: the nation's economic misfortunes, government policy, changing demand, increasingly vocal students, faculty and alumni wishing to be consulted, and society knocking at its door. Perhaps, a hedge for the uncertainties of the years ahead for schools of dentistry would be creative, strategic planning for changes in the fund raising environment. Peter Drucker correctly points out that "Strategic planning of the most successful companies - an IBM, a Xerox, a GE, for instance - starts with the assumption that the most successful products of today are the ones which are likely to obsolete the fastest tomorrow" (Drucker, 1979 , p. 26).

In addition, few dental deans can be proficient in academics, public relations, marketing, strategic planning and fund raising. Although, a dean may hire capable people for these functions, he or she must at least have a working knowledge of all these activities since the dean should be, after all, the chief strategic planner, the head public relations official and the key-person in fund raising. Hence, a basic knowledge is required in order for the academic leader to be conversant with the executives in charge of various areas.

To the same extent, Sprunger and Berquist $(1978$, p. 4) succinctly stated:

Administrators and managers are responsible for:

Assuring that the mission and goals of the organization are current, viable, and operational; 
- Maintaining a flexible organization that can respond to changing needs;

- Obtaining, maintaining, utilizing, and controlling resources;

. Providing an equitable flow and distribution of services; and

. Meeting both the internal and external expectations of the supporting constituents.

However, any development effort should be coordinated through the development office as the development officers are professionals trained in preparing proposals as well as in identifying and securing financial support. Consequently, it is essential that academic leaders consider it their responsibility to work in conjunction with the development office in a joint effort to raise funds.

Most institutions of higher education have published policies and procedures that coordinate fund raising activities through a development office. Moreover, according to Broce (1979, pp. 17-24), there are nine principles of fund raising that form the basis of any sound development program:

1. Institutional or Organizational Objectives Must Be Established Schools or colleges must have current objectives that are consistent with those of their respective university.

There are many methods for establishing a long-range plan and a process for allocating resources according to Corneske and Bolte (1986).

2. Development Objectives Must Be Established to Meet Institutional Objectives

Academic leaders and development officer must be able to communicate to potential donors the objectives and needs of the institution as well as to demonstrate how the potential funds will be allocated to meet these objectives. 
3. The Kinds of Support Needed Determine The Kinds of Fund Raising Programs Implemented

Each objective should be matched with the most appropriate source of funds, i.e., a capital campaign, endowment programs, etc.

4. The Institution Must Start With Natural Prospects

The most natural and best prospects are those that have given in the past.

5. The Case For The Program Must Reflect The Importance of The Institution

A brief and clear statement must be prepared and used in all promotional material.

6. Involvement Is The Key To Leadership And Support

An effective fund raising effort occurs when all of those involved participate in every aspect, from planning to solicitation.

7. Prospect Research Must Be Thorough And Realistic

The identification of potential donors and evaluating the potential giving power of a donor are ongoing processes.

8. Cultivation Is the Key To Successful Solicitation

Cultivation is constant and varied.

Three groups of prospects:

- Those ready to be solicited;

- Those who are interested, but not quite ready for solicitation; and

- Those who have a potential for giving, but have not been approached. 


\section{Solicitation Is Likely To Be Successful Only If Principles One Through Eight Have Been Followed}

Successful solicitation of a donor depends on the motivation of others in the solicitation process.

The solicitation should be coordinated through the development office.

Working with the university development office, the office of development of a school or college can help the dean identify and cultivate potential donors.

As Kunec (1982) noted:

One of the most time-consuming tasks for any fund-raiser is identifying and cultivating donors. Research, whether that be searching through directories of foundations, meeting with influential friends or the power block in the community, or any other form, is the secret to finding those individuals, foundations, corporations, and community organizations that would be interested in helping you achieve your mission. (p. 26)

A school or college mission statement should support the university mission statement.

According to Guardo (1982):

A university mission statement sums up the academic identity of the institution. It covers the type of educational institution the university is, the kind of educational philosophy it espouses, and the specific educational aims and purposes it seeks to fill. (p. 24)

A school or college case statement should be supportive of and consistent with the university case statement. 
According to Kunec (1982, pp. 26-31):

The case statement is a document that states the well-researched arguments that express an internal consensus on your organization's rationale for existence.

Kunec suggests that the case statement contain six elements:

1. A section on history and tradition that should define why the school was founded, its philosophy, and heritage. This section should also include information on the school's mission and why it was established;

2. A description of the school's services should be provided along with how the school serves the community;

3. How the school intends to improve its current capabilities, its long range plans, and how this will impact the community;

4. A description of the students, faculty, administration, and alumni and friends of the school;

5. An invitation to others asking them to participate in determining the future of the school; and

6. Outline opportunities for giving, which includes time, resources, and money.

Pray (1981) suggests that the case statement is "the sales tool for development" (p. 19) and according to Frantzreb (1979): "The case statement of the institution is assumed as the thread linking all parts of the solicitation process together" (p. 4). Hence, a case statement should be brief and clearly state the objectives, need, and value in meeting that need. It should be specific to the 
school, while at the same time, speak to larger entities of the university; and it should have the approval of the university's administration as well as the dean of the school.

According to Shea (Rowland (ed.), 1978, p. 476), traditional fund raising programs in a comprehensive development platform include:

- Annual Giving

- Capital Campaigns

- Major Gift Solicitation

- Deferred or Planned Giving

- Foundation Giving

- Corporate Giving

- Athletic Fund Raising

Shea noted that the fund raising sources and constituencies include:

- Alumni

- Non-Alumni Friends

- Corporations

- Foundations

- Governing Boards

- Clubs and Organizations

- Parents

- Students

- Faculty and Staff

In the maintenance of an effective donor record system:

Broce (1979) suggests that donor prospect evaluation and identification should be an interminable development activity. (pp. 23-24) 
According to Pray (1981):

The effective program identifies significant potential donors, develops information about each one to provide a sound base for action, suggests and guides prospect cultivation, and gives staff assistance to those making direct donor contact. Such a program is supported by an effective record system and adequate staff... it is a system to identify and provide in-depth information on the 20,50 , or 200 individuals or organizations capable of making a major impact on the institution if motivated to help. (pp. 81-82)

Bergfeld (Pray (ed.), 1981) clearly states:

Somehow, every institution must be able to record items of categorized information in some form of master record for qualified selection of prospects... Before calling on a prospect, the executive needs up-to-date prospect information in as concise a format as practicable. This is the work of the prospect researcher - - work made infinitely easier and more valuable if a good prospect file exists. (pp. 270-271)

Conceivably, a successful fund raising program requires time, effort, effective marketing, and skillful strategic planning. Moreover, if fund raising is to be productive, it should be under the ultimate responsibility and authority of the dean and the school's senior development officer, who in turn, coordinates the efforts of the people involved in fund raising activities. Arguably, the school is looking for a sustainable contributions program that is achievable; however, it is essential that the school and university speak with one coordinated voice regarding the school's fund raising policies as well as the university's overarching policies.

According to Howe (1983, pp. 19-23):

Not by chance is the fund raising activity referred to as "development." Nor is development simply a sugar coated euphemism. The concept of development involves the formulation and articulation of a clear sense of mission for an institution and taking the necessary steps - including communication with 
constituents, and raising essential revenues - - to make possible the fulfillment of that mission. Accordingly, the first and critical step is to have a clear statement of mission and institutional plan: to know what the organization is doing, how it differs from others, how it fits into the community around it, and where it expects to go.

Howe continues by pointing out:

The culmination of all fund raising is solicitation, asking for contributions - - in raising money from individuals, corporations, or foundations, the tasks of planning, research, and cultivation will dictate who should do the asking, when they should do it, and how much they should ask for. - - People who give money, particularly in major accounts, do not want to deal with development staff; they want to talk to a trustee, a volunteer, or the chief executive.

\section{SUMMARY}

Philanthropy was recorded as early as the 21 st century B.C., and has had an enormous impact on the development of a unique system of higher education in the United States. Moreover, the literature suggests that philanthropy has always been a fundamental element in the viability of higher education in America. From the earliest private colonial colleges to the modern research universities, philanthropic support has been sought from a variety of private sources.

However, as colleges and universities approach the 21st century A.D., there will continue to be an escalating competition for both students and other financial support from private sources as well as from the states and the federal government in a time when criticism of the costs and benefits of higher education is increasing.

Academic leaders generally have borne the burden of fund raising for 350 years since the founding of Harvard College. But with the concentration of wealth engendered by the Industrial Revolution and with the proliferation and 
willingness of wealthy individuals to financially support American higher education, colleges and universities began to utilize professional fund raisers to search out and use modern fund raising methods to uncover new funding sources. As a result, colleges and universities began developing their own fund raising staffs and a number of interdependent support organizations developed which are now merged into the Council for Advancement and Support of Education. Hence, with the prospect of declining enrollments, increased competition for and dependency upon state and federal dollars, and an unstable economy, it is imperative that American higher education, working with the Council for Advancement and Support of Education, aggressively pursue philanthropy from all sectors of society.

In sum, notwithstanding that schools of dentistry comprise a large segment of American higher education and its health science schools, there is a paucity of research about fund raising in schools of dentistry. Given this plight, this study is concerned with assessing the institutional advancement processes at selected American schools of dentistry. It addresses the need to improve the process of institutional advancement as one means of strengthening the prospect for future survival of schools of dentistry.

In the following chapter, this thesis approached the research of this problem by using the following as a guide:

- What are the institutional characteristics of American schools of dentistry with successful fund raising programs?

- How are the offices organized in American schools of dentistry with successful fund raising programs?

- What are the sources from which these American schools of dentistry received financial support? 


\section{POSTSCRIPT}

The preceding review of the literature presented an aspect of fund raising that may well provide a fertile field for additional scholarly investigation: in the area of fund raising in American higher education, there appears to be a recognizable community of thought, a growing body of literature, a dynamic research quest, and an application of the knowledge in practical affairs. These developments suggest that the study of fund raising may well be on the threshold of becoming a field of specialized inquiry in the discipline of academic administration. However, the methods, knowledge, and theory in fund raising have not yet evolved into an articulate, defined, and well-integrated course of study. Despite the existence of an abundant and wide-ranging literature, the area has no comprehensive statement of its concepts, theory, and knowledge. One of the central tasks facing the fund raising area is that of achieving some coalescence of its effort so as to crystallize its identity as a prospective specialization in the art and science of academic administration. 


\section{RESEARCH METHODOLOGY AND PROCEDURES}

\section{METHODOLOGY}

The prime purpose of this study was to identify and analyze advancement activities of selected American schools of dentistry. An attempt was made to identify the most effective procedure in soliciting philanthropic support for these institutions by an in-depth analysis of the organization, management, and methods and techniques that were associated with a successful course of action.

The study was designed to acquire significant descriptive information on programmed advancement activities at American schools of dentistry for comparative purposes. This was accomplished through the implementation and analysis of a survey of each of the schools of dentistry in the United States including Puerto Rico and personal interviews with each of the deans and senior development officers at the five schools of dentistry in California.

The data for this study was collected from three sources and by three methods:

- The mailing of a questionnaire survey to the deans and senior development officers at all the schools of dentistry in the United States and Puerto Rico;

- Interviews with the deans and development officers at the five schools of dentistry in the state of California (two public and three private):

University of California, Los Angeles, School of Dentistry

Center for the Health Sciences

Los Angeles, California 90024-1668 
University of California, San Francisco, School of Dentistry

Third and Parnassus Avenues

San Francisco, California 94143

Loma Linda University School of Dentistry

Loma Linda, California 92350

University of the Pacific School of Dentistry

2155 Webster Street

San Francisco, California 94115

University of Southern California School of Dentistry

University Park - MC-0641

Los Angeles, CA 90089-0641

- Comparative analysis of the results of advancement activities from all the schools of dentistry in the United States and Puerto Rico.

\section{POPULATION AND SAMPLE}

The population of the study consisted of the 55 private and public schools of dentistry in the United States and Puerto Rico. The sample selected was the entire population - a census.

The population is geographically distributed throughout the United States, with the majority of the institutions (thirty-seven) located in 24 states east of the Mississippi. Twenty-six institutions are located on the eastern seaboard (seventeen in Middle Atlantic and New England states, eight in southern states and one in Puerto Rico). Seventeen are located in the upper midwestern states of lowa, Wisconsin, Kentucky, Missouri, Nebraska, Minnesota, Illinois, Indiana, Michigan and Ohio. Twelve institutions are located west of the Mississippi, with the majority (five institutions) located in the state of California. 
The population of the study is listed below alphabetically with general descriptive information about each institution:

Alabama, University of

School of Dentistry

Birmingham, AL

The school of dentistry is located on the campus of the University of Alabama at Birmingham. It is an integral unit of the large complex of medical facilities. The school was created in 1945 by an act of the state legislature and the first class matriculated in 1948.

Baylor College of Dentistry

Dallas, TX

Baylor College of Dentistry evolved as a dental educational institution first chartered by the state of Texas in 1905 . It was known as the State Dental College and continued in operation from 1905 until 1918, when it was accepted in the university system of Baylor University. Baylor University College of Dentistry continued under this system until 1971, when it became a private, non-profit corporation under the name of Baylor College of Dentistry. In this changed status, it is affiliated with the Texas Higher Education Coordinating Board, as a state-assisted institution. The College of Dentistry is located in the Dallas metropolitan area and is situated within the Baylor Medical Center complex, although it is a distinct corporate entity.

\section{Boston University Medical Center}

Henry M. Goldman School of Graduate Dentistry

Boston, MA

The Boston University School of Graduate Dentistry is located on the campus of Boston University. It is an integral unit of the large complex of
medical facilities.

California, Los Angeles, University of

School of Dentistry

Los Angeles, CA

The UCLA School of Dentistry was established in 1960 by the Regents of the University of California. The school is located in the Center for Health Science on the UCLA campus providing facilities for four classes of 88 dental students each. UCLA is a state-supported institution. 
California, San Francisco, University of

School of Dentistry

San Francisco, CA

UCSF School of Dentistry has been part of the University of California since 1881. The San Francisco campus consists of four professional schools in Dentistry, Medicine, Pharmacy, and Nursing. It is the only one of the nine University of California campuses devoted solely to the health sciences. UCSF is a state-supported institution.

\section{Case Western Reserve University}

School of Dentistry

Cleveland, $\mathrm{OH}$

Case Western Reserve University was created in 1967 by the formal alliance of Western Reserve University and Case Institute of Technology. The origins of the university date back to 1826 and the school of dentistry was organized in 1892 . Since 1969, the school has been located in the Health Science Center on the main campus.

Colorado, University of

School of Dentistry

Denver, CO

The Colorado legislature authorized the establishment of the School of Dentistry in 1967 and the first class of 25 students was admitted in 1973. It is an integral part of the large complex of medical facilities of the University of Colorado.

\section{Columbia University}

School of Dental and Oral Surgery

New York, NY

The school of Dental and Oral Surgery of Columbia University is a private dental school in the city of New York. The dental school is an integral part of the Columbia Presbyterian Medical Center. It traces its origin to the year 1852, when the New York State Legislature chartered the New York College of Dental and Oral Surgery. The college became the School of Dental and Oral Surgery of Columbia University in 1916.

Connecticut, University of

School of Dental Medicine

Farmington, CT

The University of Connecticut School of Dental Medicine is located at the Health Center in Farmington which includes the School of Medicine and the
John Dempsey Hospital. 
Creighton University

School of Dentistry

Omaha, NE

Creighton University, a private institution, was founded in 1878 . The school of dentistry was established in 1905, and the present dental facility was completed in 1973. It is an integral part of the large complex of health science facilities of Creighton University.

Detroit-Mercy, University of

School of Dentistry

Detroit, MI

The University of Detroit was incorporated in 1881 under the name of Detroit College. The institution was reorganized in 1911 and renamed the University of Detroit. The school of dentistry was established in 1932 and is a private, partially state-supported school. The University of Detroit merged with Mercy College of Detroit in 1990 to become the University of Detroit-Mercy. The dental school is located in downtown Detroit.

Florida, University of

College of Dentistry

Gainesville, FL

The College of Dentistry is a state-supported college located on the campus of the University of Florida at Gainesville. It is an integral part of the J. Hillis Miller Health Science Center and the first class of 24 students was admitted in 1972.

Georgia, Medical College of

School of Dentistry

Augusta, GA

The Medical College of Georgia is an autonomous institution within the university system of Georgia. The School of Dentistry was authorized by the Board of Regents in 1965. The first class enrolled in 1969.

Harvard University

School of Dental Medicine

Boston, MA

The Harvard School of Dental Medicine, established in 1867, was the first university-affiliated dental school in America. The school provides a comprehensive education in dentistry as a specialty of medicine with a
five-year program that was inaugurated in September, 1979 . 
Howard University

College of Dentistry

Washington, D.C.

The College of Dentistry is a major component of the Howard University Center for the Health Sciences. The college originated as a department within the School of Medicine in 1881. Howard University College of Dentistry has graduated more Afro-American dentists than all other American dental schools combined.

Illinois at Chicago, University of

College of Dentistry

Chicago, IL

The College of Dentistry was founded in 1898 as the Columbian Dental College. It became an integral part of the University of Illinois in 1913. The College is located in the University of Illinois at Chicago Health Sciences Center.

Indiana University

School of Dentistry

Indianapolis, IN

The School of Dentistry is an integral part of Indiana University's Medical Center in Indianapolis. The school was established as a private school in 1879 and has been a part of Indiana University since 1925.

lowa, University of

College of Dentistry

lowa City, IA

The University of lowa is a state-supported institution. The College of Dentistry, founded in 1882 , is part of the University Health Center
Complex.

Kentucky, University of

College of Dentistry

Lexington, $\mathrm{KY}$

The University of Kentucky College of Dentistry is a public institution located on the main campus of the University. The College of Dentistry, which admitted its first class in 1962, is an integral part of the
University's Chandler Medical Center. 
Loma Linda University

School of Dentistry

Loma Linda, CA

Loma Linda University School of Dentistry is a private institution located on the main campus of the University. The School of Dentistry, which admitted its first class in 1954, is affiliated with the Loma Linda University Medical Center.

Louisiana State University

School of Dentistry

New Orleans, LA

The Louisiana State University School of Dentistry admitted its first class in September 1968. The School of Dentistry is a public, state-supported institution and is an integral part of the Louisiana State University Medical Center.

Louisville, University of

School of Dentistry

Louisville, KY

The University of Louisville School of Dentistry is a state-supported institution located on the health sciences campus.

Loyola University

School of Dentistry

Maywood, IL

Loyola University School of Dentistry is a private dental school that receives capitation funds from the State of Illinois. The School of Dentistry is an integral part of Loyola University's Medical Center. It traces its origin to the year 1883 , when it was known as the Chicago College of Dental Surgery.

Marquette University

School of Dentistry

Milwaukee, WI

Marquette University School of Dentistry is an independent institution founded in 1907 when the Milwaukee Medical College affiliated with Marquette College to become Marquette University. The School of Dentistry has an in-state agreement with Wisconsin whereby state residents receive a subsidy toward their tuition. 
Maryland Dental School, University of

Baltimore College of Dental Surgery

Baltimore, MD

The Baltimore College of Dental Surgery, Dental School, University of Maryland at Baltimore, is a public institution and represents the first institution in history to offer a course in dental education. Founded in 1840 , the college was later consolidated with the Maryland Dental College and in 1923 merged with the Dental Department of the University of Maryland.

Meharry Medical College

School of Dentistry

Nashville, TN

The School of Dentistry, Meharry Medical College, is a private institution. The School originated as a department within the Medical College in 1886.

Michigan, University of

School of Dentistry

Ann Arbor, MI

The University of Michigan School of Dentistry, organized in 1875, was the first dental school established as an integral part of a state university and the second to become a part of any university.

Minnesota, University of

School of Dentistry

Minneapolis, MN

The School of Dentistry, organized in 1888 , is a state institution and is an integral part of the University of Minnesota Health Sciences Center.

Mississippi, University of

School of Dentistry

Jackson, MS

The Mississippi state legislature authorized the establishment of the

School of Dentistry at the University of Mississippi Medical Center in 1973. A first class of 25 students was admitted in the fall of 1975. The University of Mississippi Medical Center, a state-supported institution, is the state's only academic health sciences center. 
Missouri-Kansas City, University of

School of Dentistry

Kansas City, MO

The School of Dentistry is a publicly supported institution. The Kansas City Dental College (founded in 1881) and the Western Dental College (founded in 1890) merged in 1919 to form the Kansas City-Western Dental College. In 1941, this school joined the University of Kansas City, a private institution. In 1963, the University of Kansas City became part of the University of Missouri, a public institution.

Nebraska Medical Center, University of

College of Dentistry

Lincoln, NE

The College of Dentistry, University of Nebraska Medical Center at Lincoln, is a public institution. The Lincoln Dental College was founded in 1898 and was operated as a private school until 1917, when it became affiliated with the University of Nebraska. The College of Dentistry became part of the university's Medical Center in 1979.

New Jersey, University of Medicine and Dentistry of New Jersey Dental School

Newark, NJ

The University of Medicine and Dentistry of New Jersey was organized in 1970 under an act of the state legislature. It is a multi-campus institution of the health sciences and professions. The original institution from which it was developed was incorporated in 1954. The first class for the D.D.S. degree was admitted in 1956 and graduated in 1960. The class of 1965 was the first to receive the D.M.D. degree.

New York University

College of Dentistry

New York, NY

New York University College of Dentistry, a private institution, is the third oldest dental school in the United States. The College of Dentistry, located in the David B. Kriser Dental Center, is housed in two contiguous
11 -story buildings in New York City. 
New York at Buffalo, State University of

School of Dentistry

Buffalo, NY

The School of Dentistry was founded in 1892 as the fourth unit of the University of Buffalo. In 1962, the university was incorporated into the State University of New York. The school is located on the Main Street campus which has been transformed into a health science center.

New York at Stony Brook, State University of

School of Dental Medicine

Long Island, NY

The School of Dental Medicine, State University of New York at Stony Brook, was established in 1968 and admitted its first class in 1973. It is a public institution and a component of the health sciences center.

North Carolina at Chapel Hill, University of

School of Dentistry

Chapel Hill, NC

The University of North Carolina at Chapel Hill is a state-supported institution. It is the first state university in America. The School of Dentistry accepted its first class in 1950 and is a component of the health sciences center.

Northwestern University

Dental School

Chicago, IL

Northwestern University is a private university established in 1851 . The Dental School became an integral part of the University in 1891 . It is located on the Chicago campus.

Ohio State University

College of Dentistry

Columbus, $\mathrm{OH}$

The College of Dentistry, Ohio State University, is state-supported and is located in the Medical Center on the main campus of the university. The dental school was originally organized in 1890 as a department of the Ohio Medical University and was merged with Starling Medical College in 1906. In 1914, the Dental Department of Starling Ohio Medical College became the College of Dentistry of the Ohio State University and in 1925 was moved to the main campus. 
Oklahoma, University of

College of Dentistry

Oklahoma City, OK

The College of Dentistry is a state-supported institution located in the university's Health Sciences Center. The College of Dentistry graduated the first class of 24 students in 1976.

Oregon Health Sciences University

School of Dentistry

Portland, OR

The Oregon Health Sciences University School of Dentistry is a publicly supported institution. The University of Oregon Dental School was established through an act of the 1945 Oregon legislature which accepted the facilities of the North Pacific College of Oregon and incorporated them into the Oregon State System of Higher Education. In 1974, the University of Oregon Schools of Dentistry, Medicine, and Nursing were unified as the Oregon Health Sciences University.

Pacific, University of the

School of Dentistry

San Francisco, CA

The School of Dentistry of the University of the Pacific is located in metropolitan San Francisco. The school was incorporated in 1896 as the College of Physicians and Surgeons and in 1962, the College amalgamated with the University of the Pacific.

Pennsylvania, University of

School of Dental Medicine

Philadelphia, PA

The University of Pennsylvania School of Dental Medicine, founded in 1878 , is a private institution. It is located on the university campus.

Pittsburgh, University of

School of Dental Medicine

Pittsburgh, PA

The University of Pittsburgh is a state-related institution. The School of Dental Medicine, founded in 1896, is one of the schools in the university
health complex. 
Puerto Rico, University of

School of Dentistry

San Juan, Puerto Rico

On June 21, 1956, the legislature of Puerto Rico approved legislation establishing the School of Dentistry and the first class was admitted in August 1957. The school is housed with other health sciences in the Medical Sciences Building located at the Medical Center, Rio Piedras, Puerto Rico. It is fully accredited by the Council on Dental Education of the American Dental Association.

South Carolina, Medical University of

College of Dental Medicine

Charleston, SC

The College of Dental Medicine was founded in 1967 and graduated its first class in June 1971. It is a state-supported institution located in the Basic Science Building of the Medical University complex.

Southern California, University of

School of Dentistry

Los Angeles, CA

The School of Dentistry of the University of Southern California is a private institution founded in 1897 . It became a school of the university in 1947 and is located on the main campus.

Southern Illinois University

School of Dental Medicine

Alton, IL

Southern Illinois University, a state-supported institution, established the School of Dental Medicine in 1969. The dental school is located on the campus of the former Shurtleff College in Alton, Illinois.

Temple University

School of Dentistry

Philadelphia, PA

Temple University School of Dentistry, a private state-related institution, is the second oldest dental school in continuous existence in the United States. The school has close affiliations with other teaching 
Tennessee, University of

College of Dentistry

Memphis, TN

The University of Tennessee College of Dentistry is a state-supported institution, the oldest in the South, located in Memphis. The University of Tennessee, Memphis, is the state's Health Sciences campus.

Texas Health Science Center at Houston, University of Dental Branch

Houston, TX

The University of Texas Health Science Center at Houston, Dental Branch, is a state-supported institution located in the Texas Medical Center. The school was founded as the Texas Dental College in 1905, became a part of the University of Texas in 1943, and in 1972 was placed under the administration of the University of Texas Health Science Center at Houston.

Texas Health Science Center at San Antonio, University of

Dental School

San Antonio, TX

The University of Texas Health Science Center at San Antonio Dental School is a public institution created by the Texas state legislature on May 23, 1969. The first class of 16 students was accepted in September 1970 .

Tufts University

School of Dental Medicine

Boston, MA

Tufts University School of Dental Medicine, a private institution, originated 122 years ago (1870) as the Boston Dental College. It was incorporated in 1899 as a component of Tufts College. The School of Dental Medicine is located in downtown Boston in the Tufts-New England
Medical Center.

Virginia Commonwealth University

Medical College of Virginia School of Dentistry
Richmond, VA

The Medical College of Virginia School of Dentistry is a state-supported school that was created in 1893 when the University College of Medicine was opened, the Dental Department being one of its original divisions. Commonwealth health sciences complex in Richmond Virgivision and is located in a 
Washington, University of

School of Dentistry

Seattle, WA

The School of Dentistry, a state-supported institution, is located on the University of Washington's main campus. Established in 1945, the school is an integral component of the Warren G. Magnuson Health Sciences Center.

West Virginia University

School of Dentistry

Morgantown, WV

The School of Dentistry was established by an act of the West Virginia legislature on March 9, 1951, and the first class matriculated in September, 1957. The school is located in Morgantown, West Virginia, and is a component of the West Virginia University Medical Center. 
TABLE 3.1

POPULATION OF THE STUDY

\begin{tabular}{|c|c|c|c|c|}
\hline Institutions & $\begin{array}{l}\text { Degree } \\
\text { Awarded } \\
\end{array}$ & $\begin{array}{l}\text { Size of } \\
\text { Entering } \\
\text { Class } \\
\end{array}$ & $\begin{array}{l}\text { Institutional } \\
\text { Control } \\
\end{array}$ & $\begin{array}{l}\text { Devel. } \\
\text { Organ. } \\
\text { Control } \\
\end{array}$ \\
\hline $\begin{array}{l}\text { Alabama, University of } \\
\text { School of Dentistry }\end{array}$ & D.M.D. & 55 & Public & UD \\
\hline Baylor College of Dentistry & D.D.S. & 90 & $\begin{array}{l}\text { Private } \\
\text { (State-Assisted) }\end{array}$ & SD \\
\hline $\begin{array}{l}\text { Boston University Medical } \\
\text { Center, Henry M. Goldman } \\
\text { School of Graduate Dentistry }\end{array}$ & D.M.D. & 70 & Private & SD \\
\hline $\begin{array}{l}\text { California, Los Angeles, Univ. of } \\
\text { School of Dentistry }\end{array}$ & D.D.S. & 88 & Public & SD/HSD \\
\hline $\begin{array}{l}\text { California, San Francisco, Univ. of } \\
\text { School of Dentistry }\end{array}$ & D.D.S. & 80 & Public & SD/UD \\
\hline $\begin{array}{l}\text { Case Western Reserve Univ. } \\
\text { School of Dentistry }\end{array}$ & D.D.S. & 53 & Private & SD/UD \\
\hline $\begin{array}{l}\text { Colorado, University of } \\
\text { School of Dentistry }\end{array}$ & D.D.S. & 35 & Public & HSD \\
\hline $\begin{array}{l}\text { Columbia University } \\
\text { School of Dental and Oral } \\
\text { Surgery }\end{array}$ & D.D.S. & 70 & Private & HSD \\
\hline $\begin{array}{l}\text { Connecticut, University of } \\
\text { School of Dental Medicine }\end{array}$ & D.M.D. & 40 & Public & HSD \\
\hline $\begin{array}{l}\text { Creighton University } \\
\text { School of Dentistry }\end{array}$ & D.D.S. & 75 & Private & UD \\
\hline $\begin{array}{l}\text { Detroit-Mercy, University of } \\
\text { School of Dentistry }\end{array}$ & D.D.S. & 63 & $\begin{array}{l}\text { Private } \\
\text { (State-Assisted) }\end{array}$ & UD \\
\hline $\begin{array}{l}\text { Florida, University of } \\
\text { College of Dentistry }\end{array}$ & D.M.D. & 78 & Public & SD/HSD \\
\hline $\begin{array}{l}\text { Georgia, Medical College of } \\
\text { School of Dentistry }\end{array}$ & D.M.D. & 50 & Public & UD \\
\hline $\begin{array}{l}\text { Harvard University } \\
\text { School of Dental Medicine }\end{array}$ & D.M.D. & 24 & Private & SD \\
\hline $\begin{array}{l}\text { Howard University } \\
\text { College of Dentistry }\end{array}$ & D.D.S. & 80 & Private & SD \\
\hline
\end{tabular}


(cont'd.)

\begin{tabular}{|c|c|c|c|c|}
\hline Institutions & $\begin{array}{l}\text { Degree } \\
\text { Awarded } \\
\end{array}$ & $\begin{array}{l}\text { Size of } \\
\text { Entering } \\
\text { Class }\end{array}$ & $\begin{array}{l}\text { Institutional } \\
\text { Control }\end{array}$ & $\begin{array}{l}\text { Devel. } \\
\text { Organ. } \\
\text { Control }\end{array}$ \\
\hline $\begin{array}{l}\text { Illinois at Chicago, University of } \\
\text { College of Dentistry }\end{array}$ & D.D.S. & 68 & Public & UD \\
\hline $\begin{array}{l}\text { Indiana University } \\
\text { School of Dentistry }\end{array}$ & D.D.S. & 85 & Private & SD \\
\hline $\begin{array}{l}\text { lowa, University of } \\
\text { College of Dentistry }\end{array}$ & D.D.S. & 72 & Public & UF \\
\hline $\begin{array}{l}\text { Kentucky, University of } \\
\text { College of Dentistry }\end{array}$ & D.M.D. & 40 & Public & HSD \\
\hline $\begin{array}{l}\text { Loma Linda University } \\
\text { School of Dentistry }\end{array}$ & D.D.S. & 70 & Private & SD/UD \\
\hline $\begin{array}{l}\text { Louisiana State University } \\
\text { School of Dentistry }\end{array}$ & D.D.S. & Unavailable & Public & UF \\
\hline $\begin{array}{l}\text { Louisville, University of } \\
\text { School of Dentistry }\end{array}$ & D.M.D. & 50 & Public & HSD/UD \\
\hline $\begin{array}{l}\text { Loyola at Chicago, University } \\
\text { School of Dentistry }\end{array}$ & D.D.S. & 80 & $\begin{array}{l}\text { Private } \\
\text { (State-Assisted) }\end{array}$ & HSD \\
\hline $\begin{array}{l}\text { Marquette University } \\
\text { School of Dentistry }\end{array}$ & D.D.S. & $60-70$ & $\begin{array}{l}\text { Private } \\
\text { (State-Assisted) }\end{array}$ & UD \\
\hline $\begin{array}{l}\text { Maryland Dental School, } \\
\text { University of } \\
\text { Baltimore College of Dental Surgery }\end{array}$ & D.D.S. & 96 & Public & SD \\
\hline $\begin{array}{l}\text { Meharry Medical College } \\
\text { School of Dentistry }\end{array}$ & D.D.S. & 46 & Private & SD \\
\hline $\begin{array}{l}\text { Michigan, University of } \\
\text { School of Dentistry }\end{array}$ & D.D.S. & 90 & Public & SD \\
\hline $\begin{array}{l}\text { Minnesota, University of } \\
\text { School of Dentistry }\end{array}$ & D.D.S. & 75 & Public & SD/UD \\
\hline $\begin{array}{l}\text { Mississippi, University of } \\
\text { School of Dentistry }\end{array}$ & D.M.D. & 25 & Public & UD \\
\hline $\begin{array}{l}\text { Missouri-Kansas City, University of } \\
\text { School of Dentistry }\end{array}$ & D.D.S. & 75 & Public & SD/UD \\
\hline $\begin{array}{l}\text { Nebraska Medical Center, Univ. of } \\
\text { College of Dentistry }\end{array}$ & D.D.S. & 40 & Public & SD \\
\hline
\end{tabular}


(cont'd.)

\begin{tabular}{|c|c|c|c|c|}
\hline Institutions & $\begin{array}{l}\text { Degree } \\
\text { Awarded } \\
\end{array}$ & $\begin{array}{l}\text { Size of } \\
\text { Entering } \\
\text { Class } \\
\end{array}$ & $\begin{array}{l}\text { Institutional } \\
\text { Control } \\
\end{array}$ & $\begin{array}{l}\text { Devel. } \\
\text { Organ. } \\
\text { Control } \\
\end{array}$ \\
\hline $\begin{array}{l}\text { New Jersey, Univ. of Medicine and } \\
\text { Dentistry of } \\
\text { New Jersey Dental School }\end{array}$ & D.M.D. & 75 & Public & UF \\
\hline $\begin{array}{l}\text { New York University } \\
\text { College of Dentistry }\end{array}$ & D.D.S. & 156 & Private & SD \\
\hline $\begin{array}{l}\text { New York at Buffalo, } \\
\text { State University of } \\
\text { School of Dentistry }\end{array}$ & D.D.S. & 80 & Public & UF \\
\hline $\begin{array}{l}\text { New York at Stony Brook, } \\
\text { State University of } \\
\text { School of Dental Medicine }\end{array}$ & D.D.S. & 36 & Public & UD \\
\hline $\begin{array}{l}\text { North Carolina at Chapel Hill, } \\
\text { University of } \\
\text { School of Dentistry }\end{array}$ & D.D.S. & 75 & Public & SD \\
\hline Northwestern Univ. Dental School & D.D.S. & 65 & Private & UD \\
\hline $\begin{array}{l}\text { Ohio State University } \\
\text { College of Dentistry }\end{array}$ & D.D.S. & 90 & Public & UD \\
\hline $\begin{array}{l}\text { Oklahoma, University of } \\
\text { College of Dentistry }\end{array}$ & D.D.S. & 50 & Public & UD \\
\hline $\begin{array}{l}\text { Oregon Health Sciences University } \\
\text { School of Dentistry }\end{array}$ & D.M.D. & 65 & Public & SD \\
\hline $\begin{array}{l}\text { Pacific, University of the } \\
\text { School of Dentistry }\end{array}$ & D.D.S. & 125 & Private & SD \\
\hline $\begin{array}{l}\text { Pennsylvania, University of } \\
\text { School of Dental Medicine }\end{array}$ & D.M.D. & 80 & Private & SD/UD \\
\hline $\begin{array}{l}\text { Pittsburgh, University of } \\
\text { School of Dental Medicine }\end{array}$ & D.M.D. & 76 & $\begin{array}{l}\text { Private } \\
\text { (State-Related) }\end{array}$ & SD/UD \\
\hline $\begin{array}{l}\text { Puerto Rico, University of } \\
\text { School of Dentistry }\end{array}$ & D.M.D. & 40 & Public & SD \\
\hline $\begin{array}{l}\text { South Carolina, Medical Univ. of } \\
\text { College of Dental Medicine }\end{array}$ & D.M.D. & $45-50$ & Public & UD \\
\hline $\begin{array}{l}\text { Southern California, University of } \\
\text { School of Dentistry }\end{array}$ & D.D.S. & 120 & Private & SD \\
\hline $\begin{array}{l}\text { Southern Illinois University } \\
\text { School of Dental Medicine }\end{array}$ & D.M.D. & 48 & Public & UD \\
\hline
\end{tabular}


(cont'd.)

\begin{tabular}{lllll} 
Institutions & $\begin{array}{l}\text { Degree } \\
\text { Awarded }\end{array}$ & $\begin{array}{l}\text { Size of } \\
\text { Entering } \\
\text { Class }\end{array}$ & $\begin{array}{l}\text { Institutional } \\
\text { Control }\end{array}$ & $\begin{array}{c}\text { Devel. } \\
\text { Organ. } \\
\text { Control }\end{array}$ \\
\hline $\begin{array}{l}\text { Temple University } \\
\text { School of Dentistry }\end{array}$ & D.M.D. & 110 & $\begin{array}{l}\text { Private } \\
\text { (State-Related) }\end{array}$ & SD \\
$\begin{array}{l}\text { Tennessee, University of } \\
\text { College of Dentistry }\end{array}$ & D.D.S. & 90 & Public & UD \\
$\begin{array}{l}\text { Texas Health Science Center at } \\
\text { Houston, University of } \\
\text { Dental Branch }\end{array}$ & D.D.S. & 96 & Public & HSD \\
$\begin{array}{l}\text { Texas Health Science Center at } \\
\text { San Antonio, University of } \\
\text { Dental School }\end{array}$ & D.D.S. & 90 & Public & HSD \\
$\begin{array}{l}\text { Tufts University } \\
\text { School of Dental Medicine }\end{array}$ & D.M.D. & 125 & Private & UD \\
$\begin{array}{l}\text { Virginia Commonwealth Univ. } \\
\text { Medical College of Virginia } \\
\text { School of Dentistry }\end{array}$ & D.D.S. & 72 & Public & SD/UD \\
$\begin{array}{l}\text { Washington, University of } \\
\text { School of Dentistry }\end{array}$ & D.D.S. & 50 & & \\
$\begin{array}{l}\text { West Virginia University } \\
\text { School of Dentistry }\end{array}$ & D.D.S. & 40 & Public & SD/HSD \\
\hline
\end{tabular}

Key: $\quad$ D.D.S. $=$ Doctor of Dental Surgery

D.M.D. $=$ Doctor of Dental Medicine

$\mathrm{SD}=\mathrm{School}$ Development

UD = University Development

HSD $=$ Health Sciences Development

UF = University Foundation

Note: Institutions are listed in alphabetical order and are not identified by number in any manner.

The term state-related is synonymous with state-assisted.

In terms of organizational control of the school's fund raising program, four basic organizational control patterns are identified (see table 3.1, Population of the Study). The four organizational patterns for fund raising are recognized in the fifty-five American schools of dentistry, with variations evidenced in individual institutions. Seventeen of the schools of dentistry use a centralized organizational approach in which the school development office has direct control 
over its fund raising programs and reports directly to and works with the school dean. Seven schools have the development officer responsible for fund raising programs reporting directly to the health sciences development office while fifteen schools have the development officer report directly to the university development office.

Other schools of dentistry have dual organizational control over their fund raising programs where the school development officer is responsible to the school dean and to the health sciences development office $(n=3)$; where the school development officer is responsible to the school dean and to the university development office $(n=8)$; and where the school development officer is responsible to the health sciences development office and to the university development office $(n=1)$.

The fourth organizational arrangement is where the school's fund raising efforts are controlled by a foundation. Four of the schools of dentistry report the existence of a legally separate/independent university foundation which is responsible for the school's fund raising programs and serves in a supportive function for the school. However, in every case the development officer has direct access and reporting responsibilities to the school dean.

The following (Table 3.2) shows the results of the responses to a survey of American schools of dentistry deans (see footnote, p. 90 and appendices $F$ and L). Table 3.2 provides a skelton outline of institutional information for the academic years $1989-90$ and $1990-91$.

Pre-doctoral enrollment is the first variable observed in this category. Predoctoral enrollment refers to the number of students enrolled in first professional degree programs requiring four or more years of study and culminating in the first professional dental degree (i.e., D.D.S. - Doctor of Dental Surgery or D.M.D. - Doctor of Dental Medicine), awarded by a particular American college or school of dentistry. In contrast, post-doctoral enrollment 
corresponds with the number of students who have graduated from a professional school (i.e., dentistry) and who are pursuing post-graduate professional studies in a college or school of dentistry.

The variable Budget shows a comparison of the change in operating budgets for the fiscal years 1989-90 and 1990-91. The operating costs represented in the table are listed in millions of dollars and therefore, do not fully reflect the cost of running these institutions.

Tuition-Fees/Revenues compare the school revenues generated by tuition and fees for the academic years 1989-90 and 1990-91. The proceeds from tuition and fees, albeit they are a large part of the school's income, do not completely reflect the total school income. The revenues engendered by the dental and surgical treatment of patients in school clinics and hospital settings comprise a significant portion of the total revenue necessary for the operation and maintenance of American schools of dentistry.

TABLE 3.2

\section{A SURVEY OF AMERICAN SCHOOLS OF DENTISTRY DEANS}

\section{INSTITUTIONAL INFORMATION}

PRE-DOCTOBAL ENROLLLMENI

1989-90

1990-91

\begin{tabular}{lcccc} 
& Erequency & Percent & Erequency & Percent \\
$80-149$ & 3 & 9.4 & 4 & 12.5 \\
$150-219$ & 9 & 28.1 & 6 & 18.8 \\
$220-289$ & 5 & 15.6 & 2 & 6.3 \\
$290-359$ & 9 & 28.1 & 11 & 34.4 \\
$360-429$ & 2 & 6.3 & 2 & 6.3 \\
$430-499$ & 0 & 00.0 & 0 & 00.0 \\
$500-750$ & 1 & 3.1 & 1 & 3.1 \\
(Missing) & 3 & 9.4 & 6 & 18.8 \\
\multicolumn{1}{c}{ Total } & 32 & 100.0 & 32 & 100.0
\end{tabular}


$1989-90$

1990-91

6-24

25-39

40-54

55-69

70-84

85-99

$100+$

(Missing)

Total

Erequency Percent

6

18.8

21.9

18.8

6.3

9.4

6.3

00.0

18.8

Erequency

Percent

6

18.8

18.8

6.3

15.6

9.4

3.1

00.0

$\underline{6}$

100.0

28.1

32

100.0

EACULTY / FTE

$1989-90$

1990-91

$\begin{array}{ccccc} & \text { Erequency } & \text { Percent } & \text { Frequency } & \text { Percent } \\ 25-54 & 10 & 31.3 & 8 & 25.0 \\ 55-74 & 7 & 21.9 & 4 & 12.5 \\ 75-94 & 6 & 18.8 & 10 & 31.3 \\ 95-114 & 3 & 9.4 & 1 & 3.1 \\ 115-134 & 2 & 6.3 & 3 & 9.4 \\ 135-185 & 1 & 3.1 & 0 & 00.0 \\ \text { (Missing) } & \underline{3} & \underline{9.4} & \underline{6} & 18.8 \\ \text { Total } & 32 & 100.0 & 32 & 100.0\end{array}$


$1989-90$

3-44

45-79

80-114

115-149

150-184

185-219

220-250

(Missing)

Total
Frequency

13

5

1

4

3

2

1

$\underline{3}$

32
Percent

40.6

15.6

3.1

12.5

9.4

6.3

3.1

9.4

100.0
1990-91

\begin{tabular}{crr} 
Frequency & & Percent \\
\cline { 1 - 1 } 3 & & 28.1 \\
3 & 9.4 \\
3 & 9.4 \\
4 & 12.5 \\
3 & 9.4 \\
3 & 9.4 \\
1 & 3.1 \\
6 & 18.8 \\
32 & 100.0
\end{tabular}

\section{BUDGET}

\section{EY 1989-90}

Millions $\$$
$4-11$
$12-14$
$15-17$
$18-20$
$21-23$
$24-26$
$27-37$
(Missing)
Total

\section{Erequency}

10

5

3

3

2

0

1

8

32
Percent

31.3

15.6

9.4

9.4

8.3

00.0

3.1

25.0

100.0
EY 1990-91

\begin{tabular}{|c|c|}
\hline Erequency & Percent \\
\hline 10 & 31.1 \\
\hline 2 & 8.3 \\
\hline 2 & 8.3 \\
\hline 2 & 8.3 \\
\hline 2 & 8.3 \\
\hline 2 & 8.3 \\
\hline 0 & 00.0 \\
\hline 12 & $\underline{37.5}$ \\
\hline 32 & 100.0 \\
\hline
\end{tabular}




\begin{tabular}{ccccc} 
& \multicolumn{2}{c}{ EY 1989-90 } & \multicolumn{2}{c}{ EY 1990-91 } \\
Thousands $\$$ & Erequency & Percent & Erequency & Percent \\
$300-3999$ & 17 & 53.1 & 15 & 46.9 \\
$4000-6999$ & 4 & 12.5 & 1 & 3.1 \\
$7000-9999$ & 1 & 3.1 & 2 & 8.3 \\
$10000-12999$ & 2 & 8.3 & 2 & 6.3 \\
$13000-15999$ & 0 & 00.0 & 0 & 00.0 \\
$16000-19999$ & 1 & 3.1 & 0 & 00.0 \\
$20000-24000$ & 0 & 00.0 & 1 & 3.1 \\
(Missing) & 7 & 21.9 & 11 & 34.4 \\
Total & 32 & 100.0 & 32 & 100.0
\end{tabular}

\section{PATIENT CARE / REVENUES}

EY 1989-90

Thousands $\$$

400-1999

2000-2999

3000-3999

4000-4999

5000-5999

$6000-7000$

(Missing)

Total

\section{Erequency}

13

5

4

4

2

0

4

32
Percent

40.6

15.6

12.5

12.5

6.3

00.0

12.5

100.0

\section{EY 1990-91}

\section{Erequency}

Percent

10

31.3

15.6

9.4

6.3

3.1

3.1

$\underline{31.3}$

100.0

Note: For the data in the above section, Population and Sample, this researcher has relied chiefly on the following sources: "Directory of Institutional Members and Association Officers, 1991-92" (Washington, DC: American Association of Dental Schools, 1991) and "A Survey of Advancement Activities in American Schools of Dentistry" (Claremont, CA: An Unpublished Survey by Frank C. Flores, Jr., 1991). 


\section{SURVEY INSTRUMENTATION}

Notwithstanding endeavors which on their face appear to be successful to raise private philanthropic support at American schools of dentistry, the methodical study of advancement activities, utilizing social science and management based research methodologies, has not been exploited to ascertain which aspects essentially influence and enhance the potential for schools of dentistry to effectively raise private philanthropic support.

Survey research methodology was used to collect the data for this study. The data were obtained through the use of a questionnaire and through structured personal interviews with each of the deans and development officers at the five California schools of dentistry. The interviews were designed to elicit information elaborative of data provided in the returned, completed questionnaires.

Interviews, along with questionnaires, are survey techniques frequently used to collect data for descriptive studies. Survey techniques generally focus on the reconstruction of processes occuring prior to the investigation, rather than on experimental effects; hence, researchers can cover a wide range of phenomena and are not limited by a few experimental variables. Survey data can provide a great deal of information about individuals and group values, expectations and social relationships. Good and Scates (1954) observed that certain types of information, such as opinions and beliefs, can be obtained only by direct contact with people. While questionnaires can be used to obtain measures of attitudes, the interview has special value in comparison with the questionnaires.

The questionnaire was designed to collect descriptive data from deans and school development officers concerning organizational structure, management practices, and methods and techniques used by the institution in their fund raising programs, as well as their perceptions of the effectiveness of certain practices. Also, these deans and school development officers were asked for their perceptions on the most outstanding features of their fund raising programs. 
Individual persons are not quoted by name, as they were assured confidentiality in return for openess and frankness in their responses, both in the questionnaires and in the personal interviews.

As a means of determining the validity of the questionnaire content, a panel of three independent judges was selected. The panel selected was composed of senior development officers who were asked to comment on experiences relevant to the objectives of the research (See appendices B and C). The panel included the following:

John W. Crowe

Assistant Vice President for University Development

University of Southern California

Laurie A. Macaulay

Director of Development

Claremont University Center and Graduate School

Anita Comptois Reed

Director of Development

Pomona College

After the panel reviewed the general survey instrument, their suggested modifications were incorporated into the second draft which produced two separated survey instruments. One of the resulting survey instruments was directed to the school dean and the other instrument was directed to the school senior development officer. Both resulting survey instruments were derived from the general survey instrument. These prospective forms of the two resulting questionnaires were then reviewed by the researcher's dissertation committee chairperson, together with the dissertation prospectus, and were revised as a result of his recommendations (see appendices $F$ and $G$ ). 
Copies of the questionnaires and the abstract of the study were presented to the following:

\author{
Dr. Jay A. Gershen \\ President \\ American Association of Dental Schools \\ Dr. Preston A. Littleton, Jr. \\ Executive Director \\ American Association of Dental Schools
}

Thomas C. Burke, Jr.

Chairperson, Section on Communications, Development, and Public Affairs

American Association of Dental Schools

They confirmed that the Association's name could be used in the collection of data by the researcher.

\title{
DATACOLIECTIONAND RECORDING
}

The questionnaires were mailed to the deans and senior development officers in all fifty-five American schools of dentistry located in 33 states and in Puerto Rico (see appendix N). One questionnaire was submitted to the school dean and another was submitted to the senior development officer. The same institutions were used for the deans and the development officers. Respondents were asked to return the data in three weeks. The initial mailing was sent to the entire group on August 1, 1991.

A follow-up letter was subsequently mailed out on September 10, 1991 to all of the non-respondents. The follow-up letter resulted in the return of seven questionnaires from the dean group and six from the development officer group. 
Forty-five institutions (45/55) in thirty states including Puerto Rico (30/34) participated in the survey. A rate of return of 35 questionnaires $(35 / 55)$ was noted for the development officers, of which 25 (45\%) were usable. A rate of return of 35 questionnaires (35/55) from all of the deans in the census was also noted, of which $32(58 \%)$ were usable. The questionnaires that were disqualified were due to the fact that the responses were not appropriate to the analysis. Samples of the initial cover letter and follow-up letter for the two mailings can be found as appendix item $D$.

\section{Population of the Study / Institutions}

Fifty-five Institutions

- Public Institutions: 35

- Private (State-Assisted) Institutions: 5

. Private Institutions: 15

\section{Participants in the Survey / Institutions}

Forty-five Institutions

- Public Institutions: 28

- Private (State-Assisted) Institutions: 5

- Private Institutions: 12

\section{Participants Utilized in the Analysis}

Forty-one Institutions

- Public Institutions: 27

- Private (State-Assisted) Institutions: 3

- Private Institutions: 11

\section{Respondents to the Survey}

- Deans: 35

- Development Officers: 35 


\section{Responses Utilized in the Analysis}

- Deans: 32

. Development Officers: 25

A structured personal interview was conducted with the deans and senior development officers of the five California schools of dentistry. The deans and development officers were sent a letter describing the study and requesting their assistance. Subsequently, they were contacted by telephone to schedule an appointment for the interview and a follow-up letter was later mailed to confirm their appointment.

Eight interviews were conducted: Four deans and four senior development officers. An interview would last from thirty minutes to one hour in length and was tape recorded. The tape recording was made to insure accuracy of the information collected. It should be noted that one dean was unable to keep his scheduled appointment due to a conflict in schedule and one development officer was unavailable for the interview. Hence, of the ten interviews planned, only eight were available for the data analysis. However, the eight interviews were conducted at the five California schools of dentistry.

An interview guide was designed to elicit information elaborative of data provided in the returned completed questionnaires. Specimens of the interview letters, dean's interview guide, development officer's interview guide, and follow-up letters for interviews can be found as appendix items $\mathrm{H}, \mathrm{I}, \mathrm{J}$, and $\mathrm{K}$. As data were received, the quantitative information was coded and prepared for analysis. This completed the data collection phase of the study.

\section{DATA PROCESSING AND ANALYSIS}

The data obtained from the survey were manually coded and recorded by the researcher. The responses of the deans and development officers were coded and the information was entered into a data file. The data were analyzed using the 
Statistical Package for the Social Sciences (SPSS-X) on a VAX computer system at the Claremont Graduate School Computing Center. Descriptive statistics were calculated for each quantitative item on the questionnaire and where appropriate tabulations, frequency counts, and percentages were used. Each quantitative item on the questionnaire was coded for direction and magnitude of item meaning. To code importance, effectiveness, or involvement for particular items, four-point Likert scales were used:

$\begin{array}{ll}\text { Very unimportant/ineffective/uninvolved } & 1 \\ \text { Generally unimportant/ineffective/uninvolved } & 2 \\ \text { Generally important/effective/involved } & 3 \\ \text { Very important/effective/involved } & 4\end{array}$ All quantitative questionnaire items were written in the positive and thus designed to reflect the criteria of the ideal development program. Hence, the closer respondents came to scale values of 4 , theoretically, the more ideal that program as perceived by each institution's dean and/or development officer.

Not every respondent answered every question contained in the survey instrument. As a result, the number of respondents for a given question may vary. All precentages reported are adjusted for these missing data. Unreliable or unusable data were so coded and not analyzed.

Certain assumptions were made during the course of data analysis about the representativeness of the respondents. Specifically, albeit the participants may not exactly reflect the complete portrait of the population, the findings, based on a respectable number of responses including the personal interviews, should be regarded as approaching factual representation of the population. Hence, a prime assumption of this study is that the respondents are representative of the population of the study and thus support the generalizability of the findings.

Moreover, the study has been guided by the following questions:

- What are the main criteria or characteristics of an ideal development program? 
- How can individual schools of dentistry or other institutions of higher education best take advantage of the findings of this study for their development program?

The descriptive analysis enabled the researcher to draw conclusions upon which recommendations for a more effective solicitation of voluntary funding by American schools of dentistry were based. The analysis also allowed the researcher to identify patterns of organization, techniques, and management practices of the responding institutions in dentistry.

\section{DEFINITIONS}

Advancement Activities: This broad term, as used in this study, denotes the planned efforts of development, public relations, and alumni affairs working in consort to advance the interests of the institution.

Annual Giving: Generally, it is an annual unrestricted gift that helps in meeting the ongoing needs of the institution. A good annual-giving program usually leads to future major endowment, deferred, and capital gifts.

Capital Gifts: Includes gifts for new construction, renovation, and equipment. This includes gifts for the purchase of land or a gift of land itself. In-kind gifts of equipment and other non-cash items can also be included in this category.

Deferred Giving: Also referred to as Planning Giving, usually involves wills and estate planning. Deferred gifts can be made through trusts, life insurance annuities, securities, and real personal property.

Designated Giving: Includes all of those donations that people give for a specific objective, goal, or cause. It can be an endowment, capital or deferred gift. 
Development: The term, as used in this study, denotes the planned promotion of an institution, including fund raising. The term development is interchangeable with the term advancement activities unless otherwise noted.

Endowment: Includes all gifts in which the donor designates that only the income (interest) from the corpus of the donation can be used for the purpose intended. Endowments are generally used for student scholarships, academic chairs, professorships, and research programs.

Foundation: This term, as used in this study, refers to an organization established by an institution of higher education for the purpose of raising and allocating private funds for use by those same institutions. This organization, free from governmental fiscal controls, is a corporate entity related to, but legally independent of, the institution.

Fund Raising: This term, as used in this study, denotes the raising of funds from private, nongovernmental sources for the support of nonprofit institutions of higher education. For purposes of this study, the term fund raising is interchangeable with the term voluntary support unless otherwise noted.

Special Giving: Includes donations for one-time, special activities, such as seminars, social functions or special events. It can also be for one time appeals, such as buildings and improvements.

Unrestricted Giving: Includes donations that are given without designation.

Voluntary Support: The revenue obtained from all gifts, contributions, bequests, grants, and other forms of private financial support and excludes funds plus all support received from federal, state, and local governments and their local agencies (Smith, 1979), 


\section{CHAPTER FOUR}

\section{ANALYSIS AND INTERPRETATION OF DATA}

\section{INTRODUCTION}

The purpose of this chapter is to present the results of data analysis described in chapter three. The contextual framework for this analysis evolved as the data was obtained from completed questionnaires returned by the deans and senior development officers of the responding schools of dentistry, as well as the structured personal interviews with the deans and development officers of the five California schools of dentistry. The results of the analysis of the current status of advancement activities as perceived by the responding deans and development officers are described, interpreted, and summarized in this chapter.

The field of inquiry is academic leadership and management of advancement activities in American higher education with emphasis placed upon the generation and administration of programs related to fund raising in schools of dentistry. This endeavor is an acquisition of knowledge about schools of dentistry fund raising programs so as to be able to translate data retrieved into meaning derived (meaning can only be derived from a judicious interpretation of data). In other words, what is being attempted is to reach a point where, after recording the questionnaires responses and conducting the interviews, the study can address two basic questions:

What is the significance of the data?

- What are the implications for American schools of dentistry?

This chapter is divided into two major sections, each dealing with a different source of data. The first major section is organized into two divisions 
corresponding to the dean's questionnaire and to the development officer's questionnaire (see appendices F and G). Additionally, the dean division is organized into three subdivisions corresponding to the three sections of the dean's questionnaire and the development officer division is organized into four subdivisions corresponding to the four sections of the development officer's questionnaire:

. Organizational structure and management practices are presented, analyzed and interpreted.

- A treatment of fund raising sources, constituencies, and record keeping follows (for development officers only).

. Methods and techniques of fund raising are considered.

- Finally, demographic information for both dean and development officer is introduced and appended.

To balance these subdivisions, institutional information is summarized and reported in Table 3.2, A Survey of American Schools of Dentistry Deans, pp. 87 90. For additional information, see Population and Sample, pp. 69-87, which briefly describes the institutions of the study.

The second major section provides an analysis of data based upon the personal interviews conducted with the deans and development officers of the five California schools of dentistry. The purpose of the personal interviews was to ask pertinent questions in an effort to provide further clarity to the research findings (see appendices I and J). An attempt is made to give a distinct analytical treatment to fund raising data relative to an approach utilized by these deans and development officers. 


\section{DEANSURVEY}

\section{ORGANIZATIONAL STRUCTURE AND MANAGEMENT PRACTICES}

The specific problem addressed by this study is how American schools of dentistry can best organize and manage their advancement activities to maximize voluntary support. Schools of dentistry have long sought to increase available resources through the solicitation of private gifts. However, productive management activities rarely just happen. They are the harvest of thoughtful planning and guidance, and their degrees of success are often dependent on the involvement and leadership of those directing the advancement activities.

School of dentistry deans were asked to rate the involvement of various groups or individuals in establishing the overall administrative policy for the school's advancement activities and in setting institutional priorities. The following provides a comparison of their perceptions of the involvement of those individuals or groups.

The deans were asked to indicate the degree of involvement using the following scale:

$\begin{array}{ll}\text { Very Uninvolved } & 1 \\ \text { Generally Uninvolved } & 2 \\ \text { Generally Involved } & 3 \\ \text { Very Involved } & 4\end{array}$

Each quantitative item was coded for direction and magnitude of item meaning and was written in the positive; thus, designed to reflect the criteria of the model development program. Hence the closer respondents came to scale value of 4 , theoretically, the more involved was that group or individual as perceived by each dental dean. 
Table 4.1 presents the questionnaire data concerning the involvement of the dean and development officer in establishing the overall administration policy for the school's advancement activities. The involvement of the dean is perceived to rate the highest, with only one of the respondents rating that individual in the 'very uninvolved' category. However, even though most deans perceive their involvement in policy determination as high with a mean of 3.6, this was slightly less involved than the development officers who were rated with a mean of 3.7 by the dean respondents. It seems clear, then, that there is no significant difference between the involvement of the dean and the involvement of the development officer in establishing advancement activities policy.

TABLE 4.1

INVOLVEMENT IN ADMINISTRATION POLICY FOR ADVANCEMENT ACTIVITIES

\begin{tabular}{|c|c|c|c|c|c|}
\hline & VALUE & $F$ & $\%$ & $M$ & SD \\
\hline \multirow[t]{6}{*}{ Dean } & Very Uninvol (1) & 1 & 3.1 & & \\
\hline & Gen Uninvol (2) & 0 & 00.0 & & \\
\hline & Gen Invol (3) & 9 & 28.1 & & \\
\hline & Very Invol (4) & 22 & 68.8 & & \\
\hline & Missing (9) & 2 & $\underline{00.0}$ & & 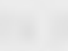 \\
\hline & & 32 & 100.0 & 3.6 & 0.7 \\
\hline Development & Very Uninvol (1) & 1 & 3.1 & & \\
\hline \multirow[t]{5}{*}{ Officer } & Gen Uninvol (2) & 0 & 00.0 & 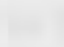 & \\
\hline & Gen Invol (3) & 3 & 9.4 & & \\
\hline & Very Invol (4) & 18 & 56.3 & & \\
\hline & Missing (9) & 10 & $\underline{31.3}$ & & \\
\hline & & 32 & 100.0 & 3.7 & 0.7 \\
\hline
\end{tabular}


Nevertheless, as noted in Table 4.2, only ten deans or 31.3 percent of the respondents stated that the development officer is 'very involved' in providing effective leadership for the school's advancement activities and nine deans or 28.1 percent stated that the development officer is 'very involved' in establishing fund raising policy. While on the contrary, twenty deans or 62.5 percent of the respondents rated themselves as most involved in establishing fund raising policy.

The dean, who is normally charged with policy decisions, is generally thought of by the dental school community as much less involved in establishing overall advancement activities policy than the development officer. However, coupled with the above perceived heavy involvement of the dean in advancement activities policy, this suggests that the scope of involvement of the development officer in policy decisions for advancement activities is very narrow.

In responding to the question concerning the dean's involvement in seeking financial support, nineteen deans or 59.4 percent of the respondents indicated that the dean was 'very involved' and seventeen deans or 53.1 percent rated the development officer as 'very involved' in seeking funds. Whereas, in response to the question about soliciting potential major donors, twenty deans or 62.5 percent of the respondents rated themselves as 'very involved' while twelve deans or 37.5 percent classified the development officer as 'very involved.' In regard to soliciting potential major donors, it appears that extensive involvement of the school development officer is lacking.

In evaluating the school's advancement activities, sixteen deans or 50.0 percent of the respondents (mean 3.3) rated themselves as 'very involved' while fourteen deans or 43.8 percent of the respondents (mean 3.4) rated the development officer as 'very involved.'

It is interesting to note that a consistent number $(n=9)$ of dean respondents did not complete all of the above questions regarding the development officer's 
involvement in the school's advancement activities. The dean respondent left blank the items on which they did not have data available, preferred not to answer, or which did not apply, while all thirty-two dean respondents answered all of the above questions regarding the dean's involvement. Consequently, the number of respondents used to calculate comparisons varied.

\section{TABLE 4.2}

INVOLVEMENT IN ADVANCEMENT ACTIVITIES

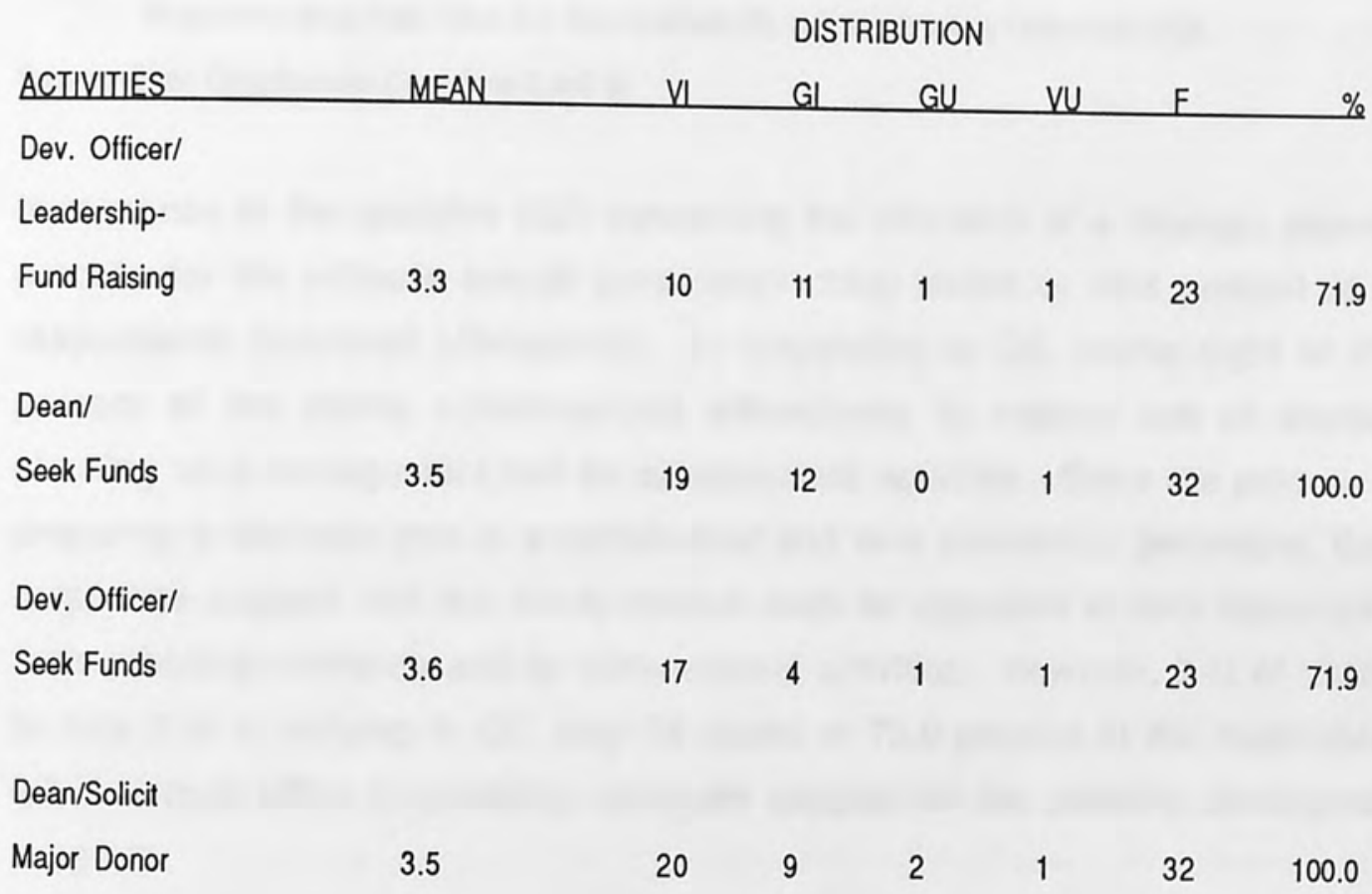

Dev. Officer/Solicit

Major Donor

12

2

7

2

2

23

71.9

Dean/Evaluate

Fund Raising

3.3

$16 \quad 11 \quad 3$

2

$32 \quad 100.0$

Dev. Officer/Evaluate

Fund Raising

3.4

14

6

1

2

23

71.9 
(cont'd.)

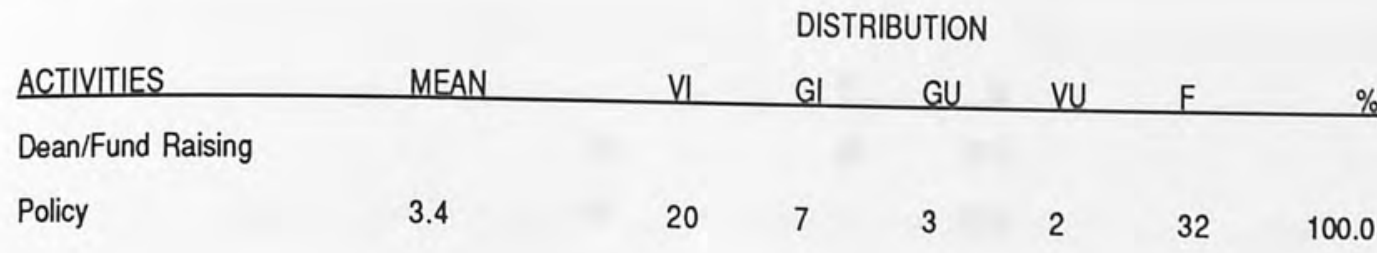

Dev. Officer/Fund

Raising Policy

910

22

23

71.9

Responses range from Value $4=$ Very Involved (VI) to Value $1=$ Very Uninvolved (VU).

Source: Dean Questionnaire (Questions 5 and 6)

In response to the question (Q2) concerning the utilization of a strategic planning process for the school's overall governance, thirty deans or 93.8 percent of the respondents answered affirmatively. In responding to Q3, twenty-eight or $\mathbf{8 7 . 5}$ percent of the deans acknowledged affirmatively to making use of strategic planning as a management tool for advancement activities. Since the process for preparing a strategic plan is a complicated and time consuming procedure, these responses suggest that the deans believe such an approach is very important to their school governance and its advancement activities. However, it is of interest to note that in replying to $Q 7$, only 24 deans or 75.0 percent of the respondents felt that their office is providing adequate support for the school's development program.

Q2 Does the school have a strategic planning process for its overall governance?

$\begin{array}{lrr} & \text { F } & \% \\ \text { Yes } & 30 & 93.8 \\ \text { No } & 2 & 6.2 \\ \text { Missing } & \underline{0} & \underline{00.0} \\ & 32 & 100.0\end{array}$




$\begin{array}{lcr} & \text { E } & \% \\ \text { Yes } & 28 & 87.5 \\ \text { No } & 4 & 12.5 \\ \text { Missing } & \underline{0} & \underline{00.0} \\ & 32 & 100.0\end{array}$

Q7 Do you as dean feel that your office is providing adequate support for the school's development program based on your view of what is achieveable?

$\begin{array}{lcc} & \text { F } & \% \\ \text { Yes } & 24 & 75.0 \\ \text { No } & 6 & 18.8 \\ \text { Missing } & \underline{2} & \underline{6.2} \\ & 32 & 100.0\end{array}$

In reference to Q7, the following quotes provide a general overview of what is most and least effectively done:

- The school is beginning a fund raising effort. I'm not sure we are far enough along to comment on the most and least effective methodologies. The school is committed to a major continuous fund raising effort as a consequence of its strategic planning process.

- There is no development officer for the school. All fund-raising efforts are handled by the University Foundation.... It would be much better, although more costly, to have a development officer assigned to the school. 
- At the university... development activities are centralized in the Vice President's office.... It would be nice to have our own full-time development officer.

- Most - Annual Fund. Least - Major Gifts and Corporate Donations.

- Development director and his staff are most effective... we could always use additional help.

- Most Effective: Preparation, research on donors, overall strategy. Least Effective: Publicity.

- Development is largely centralized at (the) university level. I believe there needs to be greater participation and input at (the) school level.

- Annual Phone-a-thon is virtually our entire effort (and is) very effective for us. Other methods need to be developed.

- Only recently (last 5 years) has the alumni been involved, but is most effective now. Have not yet had an effective development officer (3 attempts).

- Development very embryonic at present.

- In the college's development operation, the largest gifts are usually secured through individual cultivation of major prospects by the dean. This cultivation process is deliberately construed by the director of development to provide prospect names, gifting opportunities, research, meetings and the like. Identification of non-alumni prospects is particularly challenging to us. 


\section{DEVELOPMENT OFFICER SURVEY}

ORGANIZATIONAL STRUCTURE AND MANAGEMENT PRACTICES

School of dentistry development officers were asked to rate the involvement of various groups or individuals in establishing the overall administrative policy for the school's advancement activities and in setting institutional priorities. As with the deans, the development officers were asked to indicate the degree of involvement using the following scale:

$\begin{array}{ll}\text { Very Uninvolved } & 1 \\ \text { Generally Univolved } & 2 \\ \text { Generally Involved } & 3 \\ \text { Very Involved } & 4\end{array}$

Of the twenty-five development officers responding to Question 1 concerning the existence of a separate development office, seventeen development officers or 68.0 percent of the respondents indicated that they have such an entity. Those respondents, that replied in the negative $(n=8)$, volunteered comments on their negative response to the query. The following quotes provide a general overview of why their school does not have a separate development office:

- Development is a shared medical center activity - schools of public health, nursing, medicine, dentistry all participate.

- Development support activities of separate colleges, schools, and programs of the university are centralized in a separate development office of university relations. Development officers serve as development liaisons for each entity, providing coordination and communication between the dean and the centralized development staff, which is available to provide full service support for fund raising and constituent relations. 
- Development support activities are centralized... since director of development is responsible for development and alumni programs for five schools, it is impossible to spend much time with any one school.

- Currently, the development office is combined with alumni relations.

- University development is directed by the Foundation office. The Foundation directs the dental school alumni campaign.... The Alumni Association pays the Foundation a fee for this service. At this point, all funds raised go to the Alumni Association, but in the future some may go to the Foundation for university-wide projects.

Q1 Does your school have a separate development office?

$\begin{array}{llr} & \text { E } & \% \\ \text { Yes } & 17 & 68.0 \\ \text { No } & 8 & 32.0 \\ \text { Missing } & 2 & 00.0 \\ & 25 & 100.0\end{array}$

In response to Question 2 regarding the year the development office was organized, Table 4.3 shows that only one development officer or 4.0 percent of the respondents claimed that it was organized between the years 1965 to 1969 while four development officers or 16.0 percent reported a 1970 to 1974 category and eight development officers or 32.0 percent reported a 1975 to 1979 category. Just one development officer or 4.0 percent of the respondents posted an entry to the 1980 to 1984 category and six development officers or 24.0 percent posted their entries to the 1985 to 1990 category. There were no entries in the 1960 to 1964 category and five development officers or 20.0 percent did not respond. Furthermore, the responding development officers (twenty development officers or 80.0 percent) suggest that the average school development office has been in operation approximately thirteen years. 


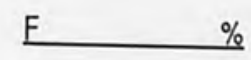

$\begin{array}{rrr}1960-64 & 0 & 00.0 \\ 1965-69 & 1 & 4.0 \\ 1970-74 & 4 & 16.0 \\ 1975-79 & 8 & 32.0 \\ 1980-84 & 1 & 4.0 \\ 1985-90 & 6 & 24.0 \\ \text { Missing } & \underline{5} & \underline{20.0} \\ & 25 & 100.0\end{array}$

Source: Development Officer Questionnaire (Question 2)

In response to Question 3, 'what is the title of the school development officer?', the majority of the respondents (fifteen development officers or 60.0 percent) carried the title of Director of Development. However, nine development officers or 36.0 percent of the respondents indicated that they carried titles other than Director of Development and one development officer or 4.0 percent did not respond to the query.

The following titles other than director of development were listed by those respondents:

- Vice Dean

- Development Liaison

- Associate Director of Health Sciences Development

- Associate Director of the Medical/Dental Fund

- Assistant Dean and Director of Development

- Associate Director of Alumni Affairs and Director of Development 
- Director of Alumni Relations and Continuing Education

- Vice President/University Advancement

- Director/Health Sciences Development

The non-respondent to the query was an official of a university foundation with the title of Director/Alumni Giving and who represents the dental school in alumni giving matters.

As noted in Table 4.4, close to one-half of the development officers (eleven development officers or 44.0 percent), in responding to this query, indicated that they report directly to the dean while five development officers or 20.0 percent stated that they report jointly to the dean of the school and to the university development officer. Four school development officers or 16.0 percent of the respondents pointed-out that they report directly to the university development officer while two school development officers or 8.0 percent disclosed that they report directly to university administration and three development officers or 12.0 percent of the respondents revealed that they report to superiors at other levels.

TABLE 4.4

DEVELOPMENT OFFICER'S REPORTING RESPONSIBILITY

$\begin{array}{llr} & \text { E } & \% \\ \text { Dean } & 11 & 44.0 \\ \text { Dean/Univ } & 5 & 20.0 \\ \text { Univ Dev. } & 4 & 16.0 \\ \text { Univ Adm } & 2 & 8.0 \\ \text { Other } & 3 & 12.0 \\ \text { Missing } & 0 & 00.0 \\ & 25 & 100.0\end{array}$

Source: Development Officer Questionnaire (Question 4) 
In terms of reporting responsibility, some of the development officer respondents in the present study provided the researcher with an organizational diagram for their institution's administrative component as outined below in Figures 1 through 5 :

FIGURE 1

ORGANIZATIONAL DIAGRAM OF RESPONDING SCHOOLS OF DENTISTRY:

DEVELOPMENT OFFICER'S REPORTING STRUCTURE A

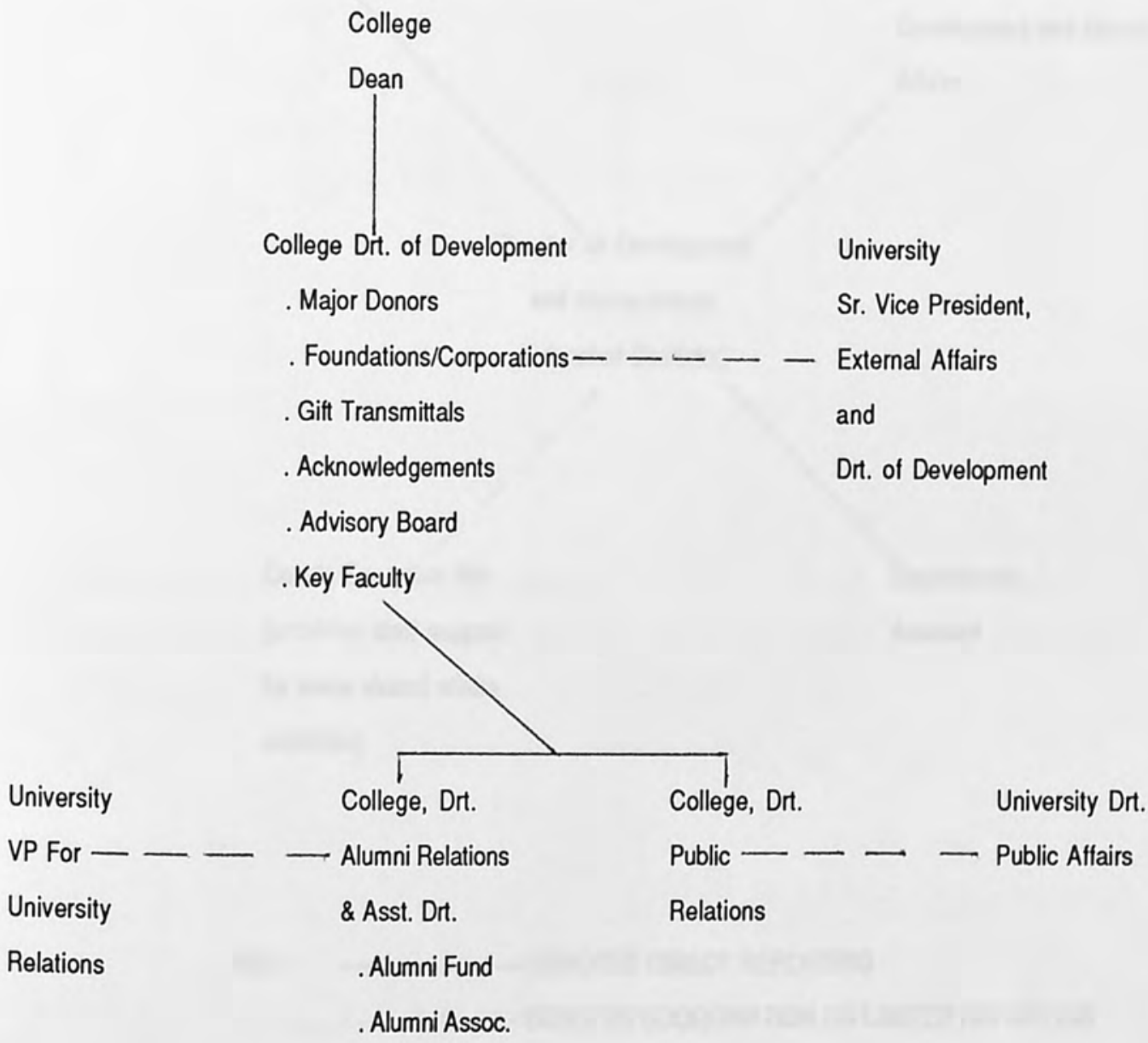

KEY: 
FIGURE 2

ORGANIZATIONAL DIAGRAM OF RESPONDING SCHOOLS OF DENTISTRY: DEVELOPMENT OFFICER'S REPORTING STRUCTURE B

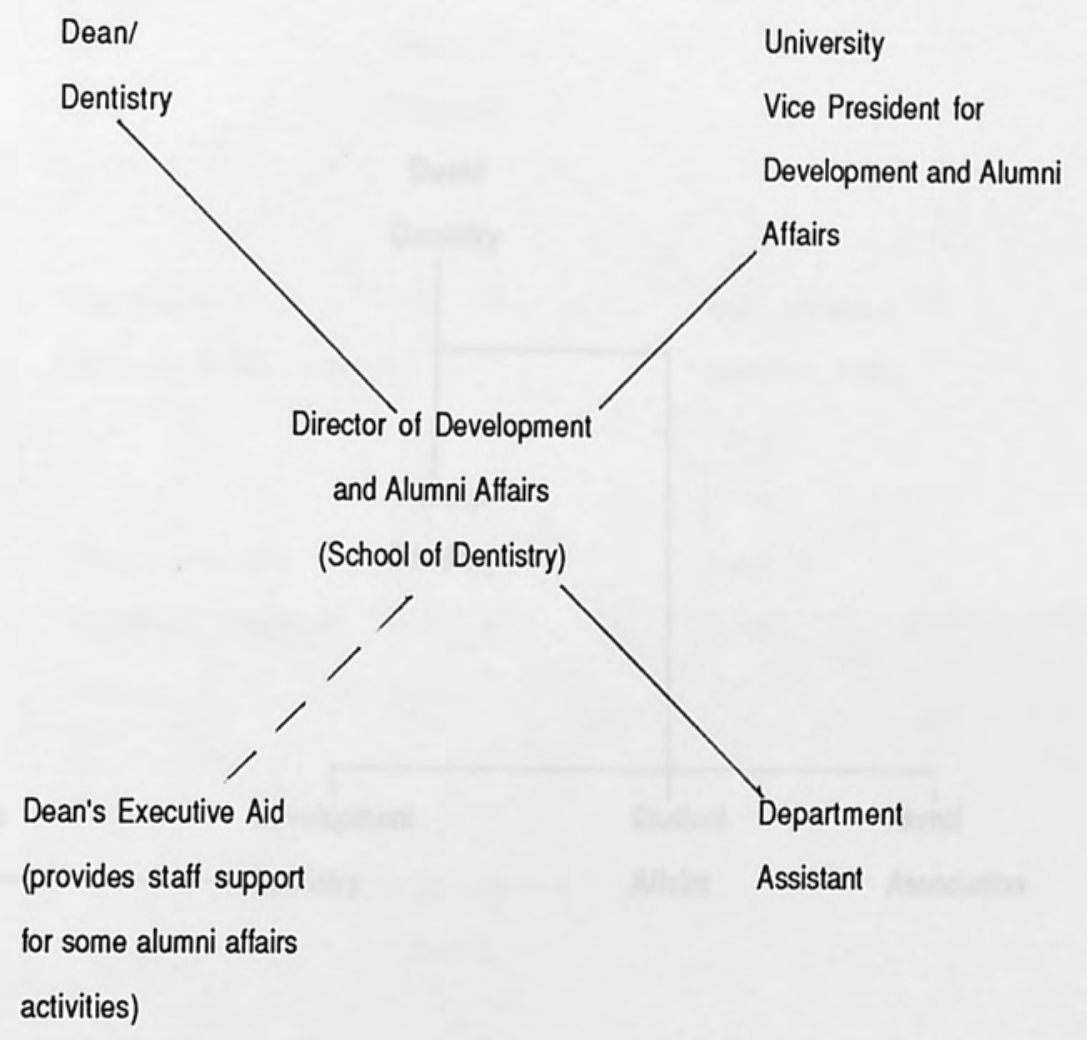

KEY: DENOTES DIRECT REPORTING - DENOTES COORDINATION OR LIMITED REPORTING 
FIGURE 3

ORGANIZATIONAL DIAGRAM OF RESPONDING SCHOOLS OF DENTISTRY:

DEVELOPMENT OFFICER'S REPORTING STRUCTURE C

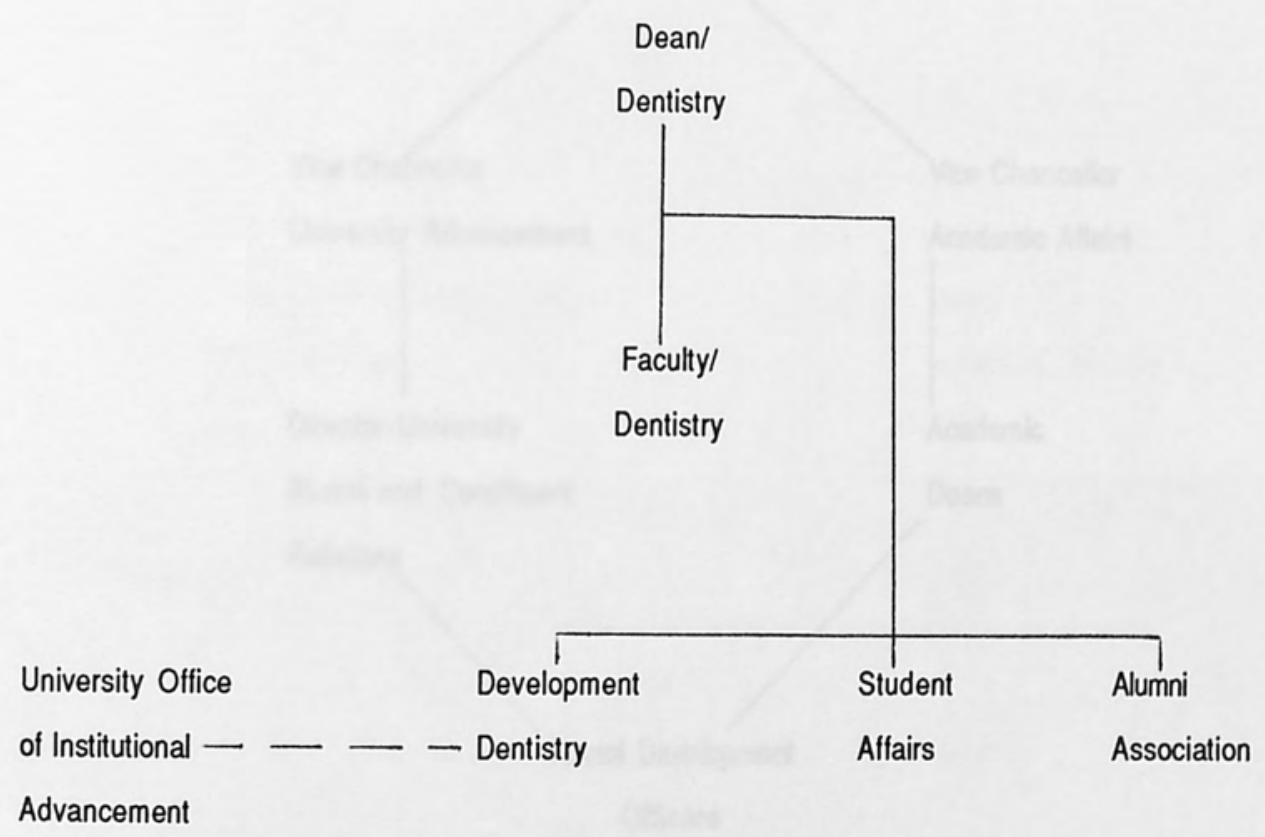

KEY: DENOTES DIRECT REPORTING - DENOTES COORDINATION OR LIMITED REPORTING 
FIGURE 4

ORGANIZATIONAL DIAGRAM OF RESPONDING SCHOOLS OF DENTISTRY: DEVELOPMENT OFFICER'S REPORTING STRUCTURE D

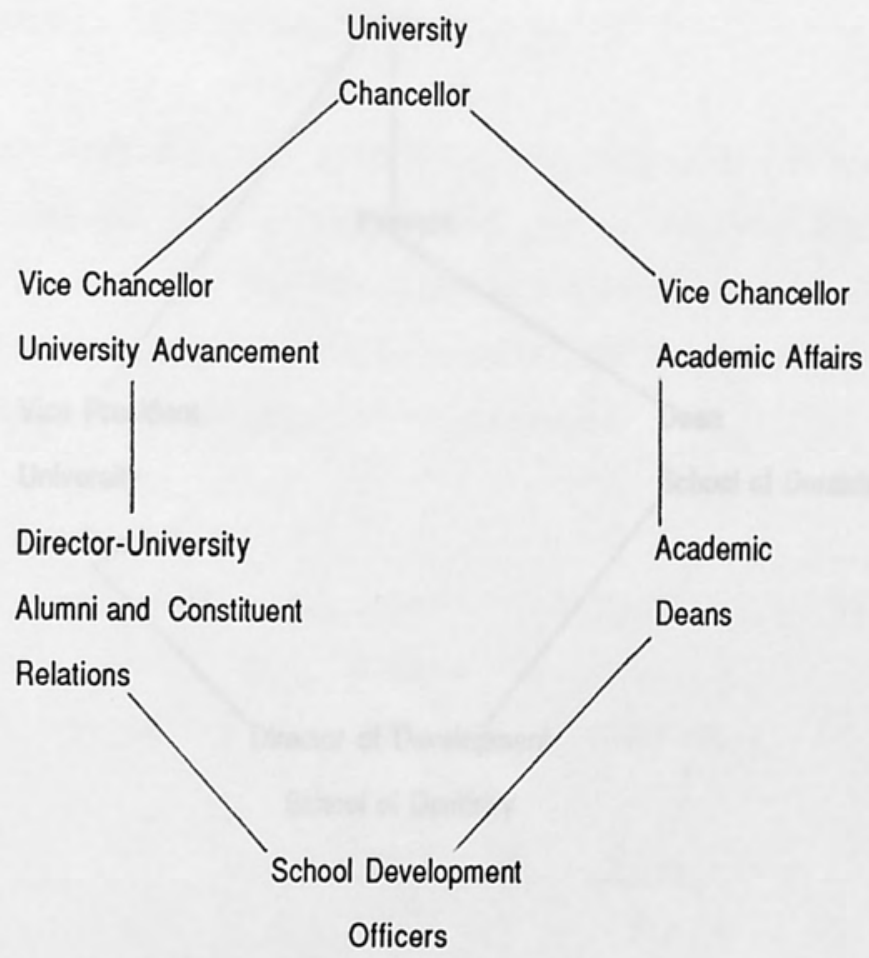

KEY: DENOTES DIRECT REPORTING 
FIGURE 5

ORGANIZATIONAL DIAGRAM OF RESPONDING SCHOOLS OF DENTISTRY: DEVELOPMENT OFFICER'S REPORTING STRUCTURE E

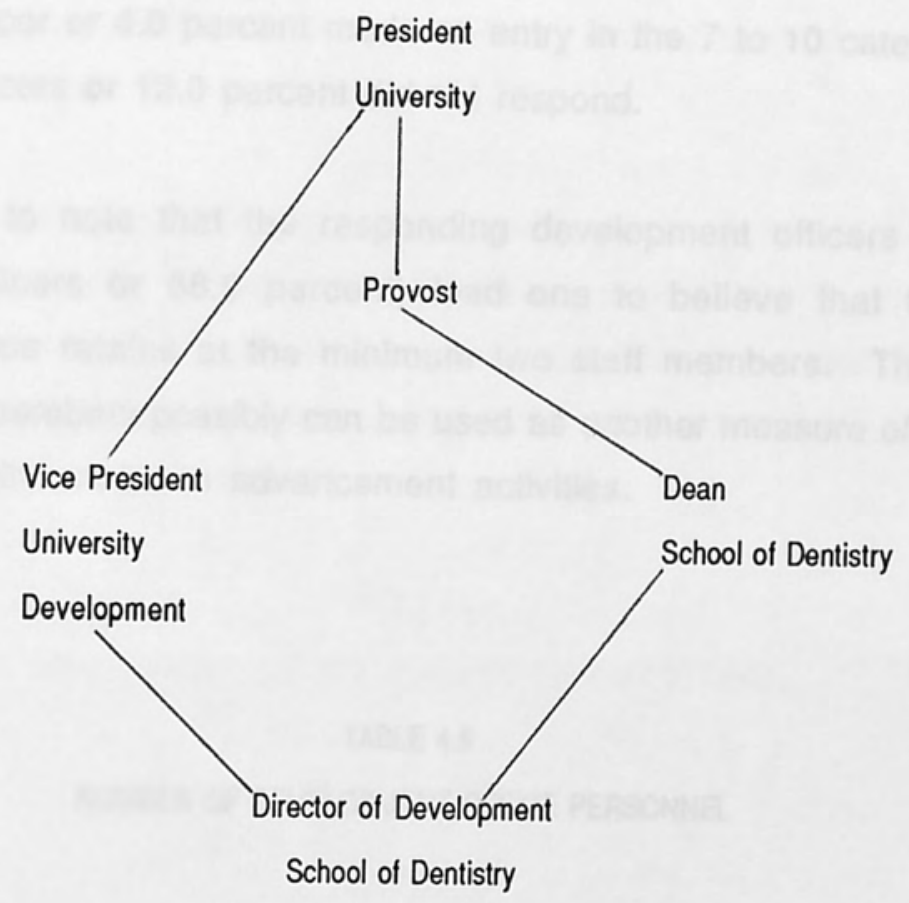

KEY: DENOTES DIRECT REPORTING 
Table 4.5 presents the questionnaire data regarding the number of development office professional and support staff. The number of development office personnel ranges from one to two individuals to seven to ten individuals with slightly more than three-quarters of the respondents (nineteen development officers or 76.0 percent) posting their entries to the 1 to 2 category. Only one development officer or 4.0 percent of the respondents replied to the 3 to 4 category; one development officer or 4.0 percent reported a 5 to 6 ; and one development officer or 4.0 percent made an entry in the 7 to 10 category. Three development officers or 12.0 percent did not respond.

It is interesting to note that the responding development officers (twenty-two development officers or 88.0 percent) lead one to believe that their school development office retains at the minimum two staff members. This minimum number of staff members possibly can be used as another measure of a school of dentistry's commitment to its advancement activities.

TABLE 4.5

NUMBER OF DEVELOPMENT OFFICE PERSONNEL

$\begin{array}{lcr} & \text { E } & \% \\ 1-2 & 19 & 76.0 \\ 3-4 & 1 & 4.0 \\ 5-6 & 1 & 4.0 \\ 7-10 & 1 & 4.0 \\ \text { Missing } & 3 & 12.0 \\ & 25 & 100.0\end{array}$

Source: Development Officer Questionnaire (Question 6) 
In response to Question 7, 'How many years experience does the school development officer have as a development professional?', Table 4.6 manifests that 24.0 percent of the respondents or six development officers reported having from 1 to 4 years of experience in the field of development. Moreover, approximately one-third of the respondents (eight development officers or 32.0 percent) claimed to have experienced 5 to 9 years in development while seven development officers or 28.0 percent acknowledged 10 to 14 years experience and three development officers or 12.0 percent enumerated 15 to 20 years of professional experience in development.

The majority of respondents (twenty-one development officers or 84.0 percent) to this query had one to fourteen years of experience in development. Furthermore, the responding development officers scored a mean of 8.6 which suggests the average development professional has experienced approximately nine years in advancement activities.

\section{TABLE 4.6}

YEARS EXPERIENCE AS A DEVELOPMENT PROFESSIONAL

$\begin{array}{llr}\text { YEARS } & \text { E } & \% \\ 1-4 & 6 & 24.0 \\ 5-9 & 8 & 32.0 \\ 10-14 & 7 & 28.0 \\ 15-20 & 3 & 12.0 \\ \text { Missing } & 1 & 4.0 \\ & 25 & 100.0\end{array}$

Mean 8.6

Source: Development Officer Questionnaire (Question 7)

Of the twenty-five development officers responding to Question 8, 'How long has the school development officer been in his/her current post?', four fifths (twenty development officers or 80.0 percent) stated that they have from 1 to 4 
years experience at their present institutions. Four development officers or 16.0 percent of the respondents reported 5 to 9 years in their current post at their school and one development officer or 4.0 percent reported 15 to 20 years. There were no entries in the 10 to 14 year category. The responding development officers registered a mean of 3.8 which suggests approximately 4 years job experience at their present institution.

TABLE 4.7

INCUMBENCY OF THE SCHOOL DEVELOPMENT OFFICER

$\begin{array}{ccc}\text { YEARS } & F & \% \\ 1-4 & 20 & 80.0 \\ 5-9 & 4 & 16.0 \\ 10-14 & 0 & 00.0 \\ 15-20 & 1 & 4.0 \\ \text { Missing } & 0 & 00.0 \\ & 25 & 100.0\end{array}$

Mean 3.8

Source: Development Officer Questionnaire (Question 8)

Interestingly, in response to Question 11 concerning the existence of a formal case statement (a published development document which outlines the goals of the school, the purpose of raising private voluntary support, and describes how private support will be utilized by the school), only ten development officers or 40.0 percent of the respondents reported that they have such an entity. Additionally, it also is of interest to note that well over one-half of the respondents (fifteen development officers or 60.0 percent) failed to acknowledge that such an entity as a formal case statement existed. The presence of such a document published by the school, which articulates the goals and objectives of the school and includes a description of how private voluntary support will be used, possibly can be utilized as one measure of the school's commitment to providing accurate and persuasive information to prospective donors. 
Table 4.8 introduces the survey data regarding the involvement of the deans, development officers and university in the development of the school's case statement. The involvement of the development officer is perceived to rate the highest, with only one of the respondents rating that individual in the 'very uninvolved' category. Additionally, in spite of the fact that most development officers perceive their involvement in the development of the school's case statement as high with a mean of 3.7 , this was slightly more involved than the deans who were rated with a mean of 3.6 by the development officer respondents. It seems clear, then, that there is no noteworthy difference between the involvement of the development officer and the involvement of the dean in the development of the school's case statement.

Nevertheless, it is interesting to note that the development officer respondents in rating the university's involvement in the development of the school's case statement, only four development officers or 16.0 percent of the respondents rated the university as being 'very involved'; notwithstanding that the university is generally thought of by the university community as being 'very involved' in the development of a case statement for its schools. Moreover, coupled with the extensive involvement of the development officers (mean 3.7) and the deans (mean 3.6) in the development of the case statement, the university scored a mean of 2.9 which suggests that the scope of the university's involvement in the development of the school's case statement is very limited. 


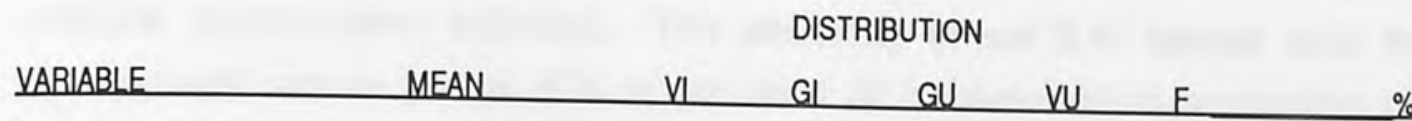

Dean/

Case Statement

3.6

13

4

0

18

72.0

Dev. Officer/

Case Statement

15

2

0

1

18

72.0

University

Case Statement

2.9

49

5

0

18

72.0

Responses range from Value $4=$ Very Involved (VI) to Value $1=$ Very Uninvolved (VU).

Source: Development Officer Questionnaire (Question 12)

In response to Question 13 concerning whether a written annual development plan, with projected goals, is prepared and presented for approval, slightly more than three-quarters of the development officers (nineteen development officers or 76.0 percent of the respondents) acknowledged affirmatively to making use of an annual development plan, while on the contrary, six development officers or 24.0 percent responded negatively. Since the process for preparing an annual development plan is a complicated and time consuming procedure, these affirmative responses suggest that the development officers believe such an approach is very important to their school and its advancement activities. 
Table 4.9 exhibits the survey data pertaining to the involvement of the dean, development officer, and university in evaluating the school's advancement activities. The development officers rated themselves as most involved (mean 3.7) in evaluating the school's advancement activities. However, a special note of interest concerning the involvement of these individuals in evaluating the school's advancement activities. The university (mean 3.4) comes after the development officer (mean 3.7) in the level of involvement in evaluating the school's advancement activities, followed closely by the dean (mean 3.3). Also of note, every development official who rated themselves as the most predominant official involved in the development of the school's case statement also rated themselves as most involved in evaluating the school's advancement activities. Of the twenty-five participating development officers, twenty-five or 100.0 percent responded to the inquiry.

TABLE 4.9

INVOLVEMENT IN THE EVALUATION OF THE SCHOOL'S FUND RAISING PROGRAM

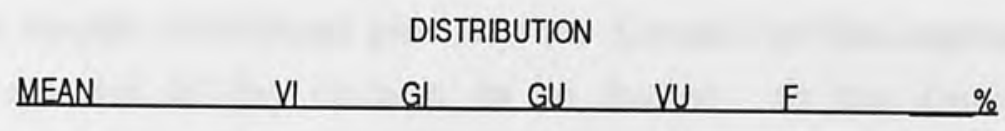

Dean/Evaluate

Fund Raising

$13 \quad 8$

3

25

100.0

Dev. Officer/Evaluate

Fund Raising

20

$4 \quad 0$

1

$25 \quad 100.0$

University/Evaluate

Fund Raising

3.4

$11 \quad 13$

1

0

25

100.0

Responses range from Value $4=$ Very Involved (VI) to Value $1=$ Very Uninvolved (VU).

Source: Development Officer Questionnaire (Question 21) 
Interestingly and in reference to the above Table 4.9, one senior development officer, in describing the management technique employed in the development program at her school, suggests that the increasing importance of the development function has made the policy-making aspects of her role more critical:

The Development function is highly appreciated by and responsive to the Dean. The Director of Development meets with the Dean formally once a week, for an hour; and, when advisable, at other times as well. All major individual cultivation and solicitation is implemented as a result of this dialogue and by the Dean and the Director of Development with additional research, prospect clearances, advice, expertise, and active solicitation from the University's development staff as requested by the Dean and the Director of Development. Foundation and corporate fund-raising is similarly implemented.

As a reflection of the Dean's commitment to Development and its importance in overall institutional planning, the Director of Development is the only director in the College to be invited to the Dean's Administrative Board which is otherwise composed of deans and meets once a week to deliberate on the College's chief administrative issues. The Director is also a member of the Executive Board which is composed of all the College's administration and also meets regularly to discuss relevant issues.

Besides actively supporting the Dean in his major donor cultivation and solicitation, the Development Director manages the Dean's Advisory Board (non-dentists with giving potential) and the "Key Faculty" (faculty who have patients with major potential and who share such names with the Development Office and participate in the cultivation process). 
The Director of Development also reports every two weeks to the University Senior Vice President for Exterior Relations in a full Development staff meeting for fund-raising directors of virtually all the schools of the University. The Director of Development of the College of Dentistry is, however, the only Director of Development to oversee the Alumni Relations and Public Affairs functions of the school in addition to being responsible for the entire Development function.

The above format has been used successfully for almost five years. It is effective because the level and constancy of the intercommunication among the Dean, the Director of Development, and the University is high, allowing the best talents of each of these sources to be used collaboratively and to the utmost.

In reference to the various criteria for evaluating advancement activities, the development officer participants were asked to rate the importance of four criteria. Table 4.10 compares the relative importance of these criteria as perceived by the development officers. The criterion, 'total funds raised', is given the highest score (mean 3.5), followed very closely and with virtually no difference by the 'number of contributors' which scored a mean 3.5. Fifteen of the twenty-five participants rated the former as 'very important' and fourteen gave the latter this high rating of importance. The criterion, 'percent of increase in funds', is rated third with a score of mean 3.4 when thirteen development officers or 52.0 percent of the respondents registered this criterion as 'very important'. The 'number of volunteer workers' placed a distant fourth with only four development officers or 16.0 percent of the respondents rating this criterion as 'very important'. 
TABLE 4.10

IMPORTANCE OF CRITERIA USED IN THE EVALUATION

OF THE SCHOOL'S FUND RAISING PROGRAM

\begin{tabular}{lllllllll} 
& \multicolumn{7}{c}{ DISTRIBUTION } \\
CRITERIA & MEAN & VI & GI & GU & VU & F & $\%$ \\
$\begin{array}{l}\text { Total Funds } \\
\text { Raised }\end{array}$ & 3.5 & 15 & 8 & 0 & 1 & 24 & 96.0
\end{tabular}

Number of

Contributors

3.5

14

8

2

0

$24 \quad 96.0$

Percent Increase

In Funds

3.4

13

9

11

$24 \quad 96.0$

Number of Volunteer

Workers

2.7

$\begin{array}{llll}4 & 9 & 11 & 0\end{array}$

$24 \quad 96.0$

Responses range from Value 4 = Very Important (VI) to Value 1 = Very Unimportant (VU).

Source: Development Officer Questionnaire (Question 22)

In response to Question 23, 'Is an annual report prepared?', seventeen development officers or 68.0 percent of the respondents answered affirmatively while eight development officers or 32.0 percent replied in the negative. 


\section{DEVELOPMENT OFFICER SURVEY}

FUND RAISING SOURCES, CONSTITUENCIES AND RECORD KEEPING

Table 4.11 presents a comparison of development officers' perceptions of the importance of various constituencies in providing supporting funds for their schools. Alumni scored a higher rating (mean 3.2) than non-alumni (mean 2.6), which is slightly higher than private foundations (mean 2.3) and business/industry (mean 2.2). Clubs/organizations received the lowest rating in importance (mean 2.0) as funding sources, perhaps reflecting the limited attention given clubs/organizations by schools of dentistry.

It is interesting to note that only eight development officers or 32.0 percent of the responding development officers rated the alumni constituency as 'very effective' (value 4) while over half (thirteen development officers or 52.0 percent) ranked alumni as 'generally effective' (value 3). Furthermore, the degree of importance in providing supporting funds for schools of dentistry is relatively low for non-alumni, private foundations, business/industry, and clubs/organizations. These remaining constituencies were, for the most part, evaluated as 'generally ineffective' (value 2) by at least 40.0 percent or more of the responding development officers. Their relatively low degree of importance may indicate either a record of little success with these constituencies or little attention given to them during the active solicitation process. 
TABLE 4.11

EFFECTIVENESS OF CONSTITUENCIES IN PROVIDING SUPPORTING FUNDS

\begin{tabular}{lllllllr} 
& \multicolumn{7}{c}{ DISTRIBUTION } \\
CONSTITUENCY & MEAN & VE & GE & GI & VI & F & $\%$ \\
\hline Alumni & 3.2 & 8 & 13 & 4 & 0 & 25 & 100.0 \\
Non-Alumni & 2.6 & 3 & 10 & 11 & 1 & 25 & 100.0 \\
Pvt./Foundations & 2.3 & 2 & 7 & 10 & 5 & 24 & 96.0 \\
Bus./Industry & 2.2 & 1 & 8 & 12 & 4 & 25 & 100.0 \\
Clubs/Orgns. & 2.0 & 1 & 4 & 11 & 7 & 23 & 92.0
\end{tabular}

Responses range from Value 4 = Very Effective (VE) to Value $1=$ Very Ineffective (VI).

Source: Development Officer Questionnaire (Question 24)

Furthermore, development officers were asked to evaluate the importance of various funding sources by the amount of development time and/or money (emphasis) expended by the school in seeking financial support from these sources. Table 4.12 shows that more than two-thirds of the development officer respondents (seventeen development officers or 68.0 percent) placed a 'heavy emphasis' (value 4) on the investment of development office time and money on the annual fund campaign while somewhat less than one-half of the development officer respondents (eleven development officers or 44.0 percent) reported a value 4 ('heavy emphasis') of time and money placed on major gift programs. However, the majority of the development officer respondents (twenty-two development officers or 88.0 percent) indicated that the prime focus of their consideration is the alumni. Consequently, they recorded a value 4 ('heavy emphasis') for the alumni category.

Alumni, annual fund, and major gift programs are rated first, second, and third, respectively. The alumni category receives the highest rating (mean 3.8 ) while annual fund receives a higher rating (mean 3.6) than major gift programs (mean 3.2), which is appreciably higher than non-alumni (mean 2.8 ), business 
and industry (mean 2.5) deferred (planned) gifts (mean 2.5), and capital projects (mean 2.5). Clubs and organizations are last in the rating of importance with a substantially lower rating of mean 2.0.

It is of interest to note that a majority of the development officer respondents (twenty-three development officer respondents or 92.0 percent) placed a moderate to heavy emphasis (value 3 and value 4 ) on the alumni and annual fund categories while nineteen development officers or 76.0 percent placed a moderate to heavy emphasis (value 3 and value 4 ) on major gift programs. Furthermore, more than one-half of the development officer respondents (fifteen development officers or 60.0 percent) placed a moderate to heavy emphasis (value 3 to value 4) on non-alumni friends while slightly more than one-half of the development officer respondents (thirteen development officers or 52.0 percent) placed a moderate to heavy emphasis (value 3 and value 4 ) on business and industry and deferred (planned) gifts categories. Finally, slightly less than one-half of the development officer respondents (ten development officers or 40.0 percent) placed a moderate to heavy emphasis (value 3 to value 4 ) on capital projects and slightly less than one-quarter of the development officer respondents (six development officers or 24.0 percent) placed a moderate to heavy emphasis (value 3 and value 4) on clubs and organizations.

The fact that the majority of development officer respondents give the alumni, annual fund and major gift programs a slightly higher rating in importance suggests some success with these funding strategies and sources. The lower rate of importance placed on non-alumni, private foundations, deferred gifts, capital projects, business and industry and the lowest rate placed on clubs and organizations perhaps suggest more time and attention should be devoted to these potential funding sources. For all one knows, an underlying reason why so little success is obtained and/or attention given to schools of dentistry advancement activities by those potential funding sources may be the relative position of these institutions within the university community compared with other health science institutions (i.e., schools of medicine). 
TABLE 4.12

EMPHASIS ON FUNDING SOURCES

\begin{tabular}{llllllllr} 
& \multicolumn{7}{c}{ DISTRIBUTION } \\
SOURCE & MEAN & HE & MODE & MINE & NOE & F & $\%$ \\
\hline Alumni & 3.8 & 22 & 1 & 1 & 1 & 25 & 100.0 \\
Annual Fund & 3.6 & 17 & 6 & 1 & 1 & 25 & 100.0 \\
Major Gift & 3.2 & 11 & 8 & 4 & 1 & 24 & 96.0 \\
Non-Alumni & 2.8 & 4 & 1 & 10 & 0 & 25 & 100.0 \\
Bus./Industry & 2.5 & 4 & 9 & 8 & 4 & 25 & 100.0 \\
Deferred Gifts & 2.5 & 3 & 10 & 9 & 3 & 25 & 100.0 \\
Capitol Project & 2.5 & 6 & 4 & 10 & 4 & 24 & 96.0 \\
Clubs/Orgns. & 2.0 & 2 & 4 & 9 & 9 & 24 & 96.0
\end{tabular}

Responses range from Value $4=$ Heavy Emphasis $(\mathrm{HE}$ ) to Value $1=$ No Emphasis (NOE)

Source: Development Officer Questionnaire (Question 25)

Moreover, development officer respondents were asked to give an account of the total number of all records stored of all potential and actual donors to their school. Table 4.13 indicates that eight development officers or 32.0 percent of the respondents reported between 1 to 4999 records and twelve development officers or 48.0 percent reported between 5000 to 9999 records while two development officers or 8.0 percent noted between 10000 to 19999 records. Three development officers or 12.0 percent of the respondents claimed between 20000 to 50000 records and the mean was 9900 records. 
TABLE 4.13

TOTAL NUMBER OF STORED RECORDS

\begin{tabular}{lrr} 
BECORDS & $F$ & $\%$ \\
\hline $1-4999$ & 8 & 32.0 \\
$5000-9999$ & 12 & 48.0 \\
$10000-19999$ & 2 & 8.0 \\
$20000-50000$ & 3 & 12.0 \\
Missing & 0 & $\underline{00.0}$ \\
& 25 & 100.0
\end{tabular}

Mean 9900

Source: Development Officer Questionnaire (Question 29)

The development officer has primary responsibility for records management with nineteen development officers or 76.0 percent of the development officer respondents performing an analysis of prior giving on an as needed basis while two development officers or 8.0 percent conduct a monthly review and four development officers or 16.0 percent execute an annual inquiry.

TABLE 4.14

FREQUENCY OF ANALYSIS OF PRIOR GIVING

$\begin{array}{lcr} & \text { E } & \% \\ \text { Monthly } & 2 & 8.0 \\ \text { Bi-Monthly } & 0 & 00.0 \\ \text { Quarterly } & 0 & 00.0 \\ \text { Semi-Annually } & 0 & 00.0 \\ \text { Annually } & 4 & 16.0 \\ \text { As Needed } & 19 & 76.0 \\ \text { Missing } & 0 & \underline{00.0} \\ & 25 & 100.0\end{array}$

Source: Development Officer Questionnaire (Question 34) 


\section{DEANSURVEY}

\section{FUND RAISING METHODS AND TECHNIQUES}

Respondents were asked to indicate the degree of effectiveness and to evaluate the importance of various fund raising methods and techniques.

Table 4.15 compares the relative effectiveness of the development office in communicating its role to the school community and fund raising constituencies. Four of the deans or 12.5 percent of the respondents gave their development office the highest rating 'very effective' and twenty-one deans or 65.6 percent of the respondents assigned it the second highest rating 'generally effective.' Evidently, the greater number of the dean respondents felt that their development office had been generally effective in identifying and publicizing its role in substantive advancement activities that may be identified as important by the community or prospective contributors.

TABLE 4.15

EFFECTIVENESS OF THE DEVELOPMENT OFFICE IN COMMUNICATING ITS ROLE

$\begin{array}{lrrrr}\text { VALUE } & F & \% & M & \text { SD } \\ & & & & \\ \text { Very Ineffct (1) } & 1 & 3.1 & & \\ \text { Gen Ineffct (2) } & 5 & 15.6 & & \\ \text { Gen Effct (3) } & 21 & 65.5 & & \\ \text { Very Effct (4) } & 4 & 12.5 & & \\ \text { Missing (9) } & 1 & 3.1 & & \\ & 32 & 100.0 & 2.9 & 0.7\end{array}$

Source: Dean Questionnaire (Question 9)

Of the thirty-two deans responding to Question 11 concerning the motivation of faculty members by the school development office to develop projects and to write proposals, twenty deans or 62.5 percent of the respondents replied in the negative while nine deans or 28.1 percent responded affirmatively. In response 
to Question 12 about the involvement of the development office in the writing of a proposal for funds, only twelve deans or 37.5 percent of the respondents answered affirmatively and seventeen deans or 53.1 percent answered negatively. Moreover, there were three non-respondents ( 9.4 percent) to both questions. Since the guidelines for writing and processing funding proposals is a complicated procedure, their responses suggest the deans believe that contract and grant opportunities are more effectively handled by another office.

Q11 Does the development office motivate faculty members to develop projects and to write proposals?

$\begin{array}{llr} & \text { E } & \% \\ \text { Yes } & 9 & 28.1 \\ \text { No } & 20 & 62.5 \\ \text { Missing } & 3 & 9.4 \\ & 32 & 100.0\end{array}$

Q 12 Does the development officer become involved in the actual writing of the proposal?

$\begin{array}{llr} & \text { E } & \% \\ \text { Yes } & 12 & 37.5 \\ \text { No } & 17 & 53.1 \\ \text { Missing } & 3 & 9.4 \\ & 32 & 100.0\end{array}$

In responding to Question 13 concerning the importance to development for the dean's office to identify and publicize substantive institutional activities that may be identified as important by the community or prospective contributors, Table 4.16 makes known that twenty deans or 62.5 percent of the respondents indicated that it is 'very important' while ten of those responding or 31.3 percent considered it as being 'generally important.' It can be said that a very large majority of the dean respondents felt that it is important to development for the dean's office to identify and publicize substantive institutional activities that may 
be identified as important by the community or prospective contributors. As one would expect, this suggests that public relations plays a vital role in the attainment of an effective development program.

TABLE 4.16

IMPORTANCE TO DEVELOPMENT FOR THE DEAN'S OFFICE TO PUBLICIZE SCHOOL ACTIVITIES

\begin{tabular}{lrrrr} 
VALUE & F & $\%$ & M & SD \\
\hline Very Unimpt (1) & 1 & 3.1 & & \\
Gen Unimpt (2) & 0 & 00.0 & & \\
Gen Impt (3) & 10 & 31.3 & & \\
Very Impt (4) & 20 & 62.5 & & \\
Missing (9) & 1 & $\underline{3.1}$ & & \\
& 32 & 100.0 & 3.6 & 0.7
\end{tabular}

Source: Dean Questionnaire (Question 13)

However, in regards to Question 14, 'How effectively does your entire school communicate its case for philanthropic support?', Table 4.17 discloses that seventeen deans or 53.1 percent of the respondents indicated that their schools were 'generally effective' while ten deans or 31.3 percent of the respondents replied that the school was 'generally ineffective' in communicating its case for philanthropic support. This indicates a lack of an effective public relations program. Moreover, the following Table 4.18 deals with the effectiveness of the university development office in aiding the school of dentistry advancement activities. Table 4.18 shows that thirteen deans or 40.6 percent of the respondents ranked the university development office as being 'generally effective' while nine deans or 28.1 percent designated the university development office as 'generally ineffective.' Additionally, with respect to Table 4.18 , the university development office received a low effectiveness score (mean 2.9) tending to confirm the assumption that this most important resource is not being sufficiently involved with the school of dentistry advancement activities to allow them to make a meaningful contribution to this vital activity. Schools of 
dentistry are also rated low in effectiveness (mean 2.7) in Table 4.17, indicating a lack of internal communication and effective utilization of its public relations program.

\section{TABLE 4.17}

EFFECTIVENESS OF THE SCHOOL COMMUNICATING ITS CASE FOR PHILANTHROPIC SUPPORT

$\begin{array}{lrrrr}\text { VALUE } & F & \% & M & \text { SD } \\ \text { Very Ineffct (1) } & 1 & 3.1 & & \\ \text { Gen Ineffct (2) } & 10 & 31.3 & & \\ \text { Gen. Effct (3) } & 17 & 53.1 & & \\ \text { Very Effct (4) } & 3 & 9.4 & & \\ \text { Missing (9) } & 1 & 3.1 & & \\ & 32 & 100.0 & 2.7 & 0.7\end{array}$

Source: Dean Questionnaire (Question 14)

TABLE 4.18

EFFECTIVENESS OF THE UNIVERSITY DEVELOPMENT OFFICE AIDING SCHOOL DEVELOPMENT

$\begin{array}{lrrrr}\text { VALUE } & \text { F } & \% & \text { M } & \text { SD } \\ \text { Very Ineffct (1) } & 1 & 3.1 & & \\ \text { Gen Ineffct (2) } & 9 & 28.1 & & \\ \text { Gen Effct (3) } & 13 & 40.6 & & \\ \text { Very Effct (4) } & 7 & 21.9 & & \\ \text { Missing (9) } & 2 & \underline{6.3} & & \\ & 32 & 100.0 & 2.9 & 0.8\end{array}$

Source: Dean Questionnaire (Question 16) 
Of the thirty-two deans responding to Question 17 concerning the importance of the school's public image, Table 4.19 shows that twenty-three deans or 71.9 percent of the respondents rated their school's public image as being 'very important' and six deans or 18.8 percent gave it a 'generally important' mark. Understandably, the public image of their institution is held in high regard by the dean respondents and the data imply that these deans perceive the school's public relations as consequential.

\section{TABLE 4.19}

IMPORTANCE OF THE SCHOOL'S PUBLIC IMAGE TO DEVELOPMENT

\begin{tabular}{lrrrr} 
VALUE & $F$ & $\%$ & M & SD \\
\hline Very Unimpt (1) & 1 & 3.1 & & \\
Gen Unimpt (2) & 1 & 3.1 & & \\
Gen Impt (3) & 6 & 18.8 & & \\
Very Impt (4) & 23 & 71.9 & & \\
Missing (9) & 1 & $\underline{3.1}$ & & \\
& 32 & 100.0 & 3.6 & 0.7 \\
Dean Questionnaire (Question 17) & & &
\end{tabular}

Nevertheless, in response to Question 18 regarding the emphasis placed on the amount of school time or money spent on improving their school's public image, Table 4.20 shows that only seven deans or 21.9 percent of the respondents placed 'heavy emphasis' while eighteen deans or 56.3 percent placed 'moderate emphasis' on the amount of school time or money expended. Furthermore, the deans' reply to Question 19 concerning the emphasis placed on the amount of time or money spent on personal visits by the dean to the school's fund raising efforts, Table 4.21 exhibits that fourteen deans or 43.8 percent placed 'moderate emphasis' and ten deans or 31.3 percent placed 'heavy emphasis' on the amount of time or money spent on personal visit by the school dean to 'fund raisers.' 
TABLE 4.20

EMPHASIS ON IMPROVING THE SCHOOL'S PUBLIC IMAGE

$\begin{array}{lcccc}\text { VALUE } & F & \% & \text { M } & \text { SD } \\ \text { No Emphasis (1) } & 0 & 00.0 & & \\ \text { Min. Emphasis (2) } & 6 & 18.8 & & \\ \text { Mod. Emphasis (3) } & 18 & 56.3 & & \\ \text { Hvy Emphasis (4) } & 7 & 21.9 & & \\ \text { Missing (9) } & 1 & \underline{3.1} & & \\ & 32 & 100.0 & 3.0 & 0.7\end{array}$

Source: Dean Questionnaire (Question 18)

TABLE 4.21

EMPHASIS ON THE DEAN'S VISITS TO FUND RAISING EFFORTS

\begin{tabular}{lrrrr} 
VALUE & $F$ & $\%$ & M & SD \\
\hline No Emphasis (1) & 0 & 18.8 & & \\
Min Emphasis (2) & 6 & 18.8 & & \\
Mod. Emphasis (3) & 14 & 43.8 & & \\
Hvy Emphasis (4) & 10 & 31.3 & & \\
Missing (9) & $\underline{2}$ & $\underline{6.3}$ & & \\
& 32 & 100.0 & 3.1 & 0.7
\end{tabular}

Source: Dean Questionnaire (Question 19)

In contrast to the data revealed in Table 4.19, the allocation of time or money to enhance the school's public image and on personal visits by the deans to their school's fund raising events does not correlate with the dean respondents' perception of the importance of the public's impression of their school. These data imply that there is a lack of internal communication within the school's community and a lack of strong leadership in strengthening and promoting the school's public relations program. 
The dean respondents were asked to comment on their perceptions of the major strengths and weaknesses of fund raising efforts in American schools of dentistry:

- With a few notable exceptions, the fund raising efforts in American schools of dentistry have been poorly developed.... We are in the process of examining these very same questions and issues.

- Strengths - None that are readily available to me.

Weaknesses - Dental schools are unable to make a significant impact on philanthropy. To my knowledge, few major gifts have been made since the days of George Eastman...

- I have no idea. The major strengths and weaknesses vary among private vs. public schools...

- Lack of financial support for the effort itself - constrained resources inhibit ability of many to support development. Many deans do not value, understand, or know how to market effectively. Many colleges are still too young to have (a) significant number of alumni who have reached an age where they can give...

- Strengths: A tradition and structure in private schools.

Weaknesses: Lack of training of dean. Lack of committed and qualified support staff. University priority to other fund raising schools especially law and medicine. Faculty disinterest and poor attitude towards students who are future alumni/contributors.

- Strengths: Private schools are doing much better than state schools. 
Weaknesses: Not well organized enough - other disciplines are much more organized. Not much corporate support - dental schools think too small in this area.

- Strengths: Alumni are very committed and dedicated...

Weaknesses: Lack of experience in fund raising. Most of us do not set our goals high enough...

- Major Weakness - Failure to convince the public of (the) value of schools of dentistry.

- I know so little about fund raising it is difficult to answer.

- Schools (of dentistry) seem to be competing too much, to the point sometimes of putting some schools down in the process.

- Most private schools have a very sophisticated program while most public schools have no program or a very rudimentary one.... I really don't think I can comment on the "strengths and weaknesses" of "the American schools of dentistry" - I simply don't know enough about the specifics of what other schools are doing.

- Some private schools have developed very effective programs. Most state schools have not.

Not knowledgable enough to respond as to strengths and weaknesses. 
- A reunion program which incorporates a class gift is a strength not only for the donation but because the reunion reignites school loyalty which may have laid dormant for many years. It also allows us to identify major donor potential.

If we are dedicated and successful in our community service, foundations are more inclined to help support those programs. We (must) allow foundations an association with a successful "work-in-progress" thereby assuring them a wise investment of funds.

Some dentists tend to be solitary individuals. If the tools of effective communication are not sharpened, then fewer of their (schools of dentistry) contacts will be motivated to support this excellent profession and service.

Dentistry can evoke painful memories in some people, including major prospects. So long as we associate support for dentistry in a purely abstract form, we may inhibit the philanthropic initiatives of those who love people! We need to make clear that dentistry helps people: the homeless, the elderly, the handicapped and the like. 
DEVELOPMENT OFFICER SURVEY

FUND RAISING METHODS AND TECHNIQUES

School of dentistry development officers were asked to appraise the involvement of the dean, alumni support groups, and the university development office in the school's advancement activities. The following Table 4.22 provides a comparison of their preceptions of the involvement of those individuals or groups as reflected by the mean scores:

\section{TABLE 4.22}

INVOLVEMENT OF THE DEAN, ALUMNI SUPPORT GROUPS (ASG)

AND UNIVERSITY DEVELOPMENT OFFICE (UDO)

IN THE SCHOOL'S ADVANCEMENT ACTIVITIES

ACTIVITIES

Leadership

3.5

2.9

Seeking

Financial Support

3.0

2.7

3.1

Soliciting

Major Donor

2.8

2.3

3.1

Soliciting

Donor

2.8

2.4

3.1

Evaluating

Dev. Programs

2.8

2.1

3.4

Establishing

Dev. Policy

2.4

2.0

3.3

Responses range from Value 4 = Very Involved to Value 1 = Very uninvolved.

Source: Development Officer Questionnaire (Questions 36, 39 and 40) 
In providing leadership for the school's advancement activities, the involvement of the dean is perceived by the majority (fifteen development officers or 60.0 percent of the respondents) to rate the highest, as being 'very involved' (value 4), while seven development officers or 28.0 percent appraise the dean as being 'generally involved' (value 3). The mean value for the dean's involvement was calculated to be 3.5 (value 4 being highest).

It is interesting to note that in parallel to the evaluation of the dean's involvement, the university development office is rated by ten school development officers or 40.0 percent of the respondents as being 'very involved' (value 4) as well as being 'generally involved' (value 3) in providing leadership for the school's advancement activities by eleven school development officers or 44.0 percent of the respondents. The mean value for the university development office involvement was calculated to be 3.3. In addition, the mean value for the alumni support groups' involvement in providing leadership for the school's advancement activities was calculated to be 2.9 .

Also of interest, the involvement of the university development office, in seeking financial support for the school, is perceived to rate the highest by the development officer respondents with a mean value calculated at 3.1 while the school's dean involvement in seeking financial support for the school is appraised by the respondents as being slightly less involved with a mean of 3.0 which is followed by the alumni support groups with a mean of 2.7 .

In responding to the questions concerning involvement in soliciting major donors and involvement in soliciting donors, the university development office, once again, is rated the highest by the school development officer respondents with a mean value of 3.1 for soliciting major donors and a mean of 3.1 for soliciting donors; while the dean's involvement is appraised as being slightly less involved with a mean of 2.8 for soliciting major donors and a mean of 2.8 for soliciting donors. Interestingly, the one constituency traditionally thought of as important 
in fund raising efforts, the alumni support groups, is rated as being generally uninvolved in soliciting major donors and soliciting donors by the development officer respondents with a low mean of 2.3 for soliciting major donors and a mean of 2.4 for soliciting donors.

With respect to the survey data concerning the involvement of various individuals/groups in evaluating the school's development programs, the university development office is rated as being very involved in evaluating the school's development programs by the development officer respondents with the highest mean value of 3.4. The dean's involvement in the evaluation of the school's development programs is rated with a low mean of 2.8 while the alumni support groups are classified as being generally uninvolved in the evaluation process with the lowest mean value of 2.1.

In response to the question concerning the establishment of the school's development policy, development officer respondents were asked to rate the involvement of various groups or individuals in establishing the overall administrative policy for the school's advancement activities.

Responsibility for the determination of overall administrative policy for the school's fund raising programs is generally thought to be primarily shared by the dean and the school development officer. The dean, who is normally charged with the school's policy decisions, also is generally thought of as much more involved in establishing the school's overall development policy than the university development office. However, the university development office is perceived to rate the highest rating in establishing the school's development policy by the school development officer respondents, with a mean score of 3.3; obviously more important than the dean who was rated at 2.4 .

Interestingly, as before, the one constituency traditionally thought of as important in the school's fund raising efforts, the alumni support groups, is generally uninvolved in establishing the school's development policy. Their 
involvement is rated low by the development officer respondents, with a mean score of 2.0

The following Tables $(4.23,4.24,4.25)$ provide a detailed appraisal of the involvement of the dean, alumni support groups, and the university development office in the school's advancement activities:

TABLE 4.23

INVOLVEMENT OF THE DEAN IN THE SCHOOL'S ADVANCEMENT ACTIVITIES

DISTRIBUTION

DEAN

MEAN

G] GU

VU $\quad F \quad \%$

Providing

Leadership

3.5

$15 \quad 7$

30

$25 \quad 100.0$

Seeking Financial

Support

3.0

$\begin{array}{llll}6 & 11 & 7 & 0\end{array}$

$24 \quad 96.0$

Soliciting Major

Donor

2.8

86

8

3

$25 \quad 100.0$

Soliciting

Donor

2.8

5

11

5

3

$24 \quad 96.0$

Evaluating

Dev. Programs

2.8

$7 \quad 8$

$9 \quad 1$

$25 \quad 100.0$

Establishing

Dev. Policy

2.4

6

6

6

7

25

100.0

Responses range from Value $4=$ Very Involved (VI) to Value $1=$ Very Uninvolved (VU).

Source: Development Officer Questionnaire (Question 36) 
TABLE 4.24

INVOLVEMENT OF ALUMNI SUPPORT GROUPS IN THE SCHOOL'S ADVANCEMENT ACTIVITIES

\begin{tabular}{llllllll} 
& \multicolumn{7}{c}{ DISTRIBUTION } \\
ALUMNI & MEAN & $V I$ & GI & GU & VU & $F$ & $\%$ \\
$\begin{array}{l}\text { Providing } \\
\text { Leadership }\end{array}$ & 2.9 & 7 & 11 & 5 & 2 & 25 & 100.0
\end{tabular}

Seeking Financial

Support

2.7

$2 \quad 15 \quad 7$

$25 \quad 100.0$

Soliciting Major

Donor

2.3

$\begin{array}{llll}1 & 8 & 13 & 3\end{array}$

$25 \quad 100.0$

Soliciting

Donor

2.4

$2 \quad 10 \quad 10 \quad 3$

$25 \quad 100.0$

Evaluating

Dev. Programs

2.1

3

3

$12 \quad 7$

$25 \quad 100.0$

Establishing

Dev. Policy

2.0

15

$12 \quad 7$

$25 \quad 100.0$

Responses range from Value $4=$ Very Involved (VI) to Value $1=$ Very Uninvolved (VU).

Source: Development Officer Questionnaire (Question 39) 


\section{TABLE 4.25}

INVOLVEMENT OF THE UNIVERSITY DEVELOPMENT OFFICE

IN THE SCHOOL'S ADVANCEMENT ACTVITIES

\begin{tabular}{llllllll} 
& \multicolumn{7}{c}{ DISTRIBUTION } \\
UNIVERSITY & MEAN & $V I$ & GI & GU & VU & $F$ & $\%$ \\
\hline $\begin{array}{l}\text { Providing } \\
\text { Leadership }\end{array}$ & 3.3 & 10 & 11 & 3 & 0 & 24 & 96.0
\end{tabular}

Seeking Financial

Support

3.1

$9 \quad 10$

4

$24 \quad 96.0$

Soliciting Major

Donor

3.1

9

9

$5 \quad 1$

$24 \quad 96.0$

SolicitingDonor

10

8

4

2

24

96.0

Evaluating

Dev. Programs

3.4

14

7

2

1

2496.0

\section{Establishing}

Dev. Policy

12

9

21

24

96.0

Responses range from Value $4=$ Very Involved (VI) to Value $1=$ Very Uninvolved (VU).

Source: Development Offiicer Questionnaire (Question 40)

In responding to Question 41 concerning the importance of coordinating the organizational relationship between the school development office and the university development office to enchance the school's fund raising, Table 4.26 shows that the majority, fifteen development officers or 60.0 percent of the respondents, indicate that the coordination of the relationship is 'very important' 
(value 4) while five development officers or 20.0 percent denote that it is 'generally important' (value 3). However, as reflected in Table 4.27, slightly more than one half of the development officer respondents, thirteen development officers or 52.0 percent, in response to the question concerning the effectiveness of the coordination, point out that the coordination of the relationship is 'generally effective' (value 3) in enhancing the school's fund raising efforts while only six development officers or 24.0 percent of the respondents state that it is 'very effective' (value 4).

\section{TABLE 4.26}

IMPORTANCE OF COORDINATING THE RELATIONSHIP BETWEEN SCHOOL AND UNIVERSITY DEVELOPMENT

$\begin{array}{lcccc}\text { VALUE } & F & \% & M & \text { SD } \\ \text { Very Unimpt(1) } & 0 & 00.0 & & \\ \text { Gen Unimpt (2) } & 3 & 12.0 & & \\ \text { Gen Impt (3) } & 5 & 20.0 & & \\ \text { Very Impt(4) } & 15 & 60.0 & & \\ \text { Missing (9) } & 2 & \underline{8.0} & & \\ & 25 & 100.0 & 3.5 & 0.7\end{array}$

Source: Development Officer Questionnaire (Question 41)

TABLE 4.27

EFFECTIVENESS OF THE COORDINATION MENTIONED IN TABLE 4.26

\begin{tabular}{lcrrr} 
VALUE & F & $\%$ & M & SD \\
\hline Very Ineffct (1) & 0 & 00.0 & & \\
Gen Ineffct (2) & 3 & 12.0 & & \\
Gen Effct (3) & 13 & 52.0 & & \\
Very Effct (4) & 6 & 24.0 & & \\
Missing (9) & 3 & 12.0 & & \\
& 25 & 100.0 & 3.1 & 0.6
\end{tabular}

Source: Development Officer Questionnaire (Question 42) 
It is of interest to note that a number of development officer respondents volunteered their perspectives on the strengths and weaknesses of their school's organizational relationship to central university development:

- Excellent Strengths: We derive expertise in specific areas (e.g., planned giving; research; trustee access; donor recognition; donor solicitation "clearance").

Major Weakness: Rare bureaucratic delays.

- Strengths: Coordination of programs; sharing of information/techniques creating (a) unified image to community and constituents.

Weaknesses: Lack of communication; difference (of) philosophy; unique donor situations (which are) unrecognized.

- Support/assistance from the central staff is not consistent; about half of the central offices are of no help and half are a great deal of help.

- The development office is equally responsible to the school and university. This is an excellent working relationship except when the dean and vice president do not agree - then the director is naturally between two bosses with different expectations...

- Historically, there has been great mistrust between (the) dental school and central administration. The Foundation, though separate, is perceived as part of central administration and therefore, the relationship has been tense at times. Cooperation is not always forthcoming.

Their strengths are their commitment to the school and their profession. Their weakness is their lack of faith in their own ability to give. 
This relationship will take many years to develop (comment volunteered by a foundation official).

Table 4.28 compares the relative effectiveness of the dean's office in communicating the role of the school development office to the school community and fund raising constituencies. Nine of the development officers or 36.0 percent of the respondents rate the dean's office as being 'very effective' (value 4) and eight development officers or 32.0 percent evaluate the dean's office in communicating the role of the school development office as being 'generally effective' (value 3). Interesting to note that slightly more than one quarter, seven development officers or 28.0 percent of the respondents, indicate that the dean's office has been 'generally ineffective' (value 2) in communicating the role of the school development office to the school community and fund raising constituencies.

TABLE 4.28

EFFECTIVENESS OF THE DEAN'S OFFICE IN COMMUNICATING

ROLE OF DEVELOPMENT OFFICE

$\begin{array}{lrrrr}\text { VALUE } & \text { F } & \% & \text { M } & \text { SD } \\ \text { Very Ineffct (1) } & 1 & 4.0 & & \\ \text { Gen Ineffct (2) } & 7 & 28.0 & & \\ \text { Gen Effct (3) } & 8 & 32.0 & & \\ \text { Very Effct( (4) } & 9 & 36.0 & & \\ \text { Missing (9) } & \text { Q } & 00.0 & & \\ & 25 & 100.0 & 3.0 & 0.9\end{array}$

Source: Development Officer Questionnaire (Question 44)

In responding to Question 45 concerning the importance of the dean's office in helping to plan and coordinate the school's fund raising campaigns, Table 4.29 shows that fourteen development officers or 56.0 percent of the respondents indicate that it is 'very important' (value 4) and ten development officers of 
40.0 percent denote it as being 'generally important' (value 3). Clearly, a large majority of the development officer respondents feel that it is important for the school's advancement activities to have the dean's office help plan and coordinate the school's fund raising campaigns.

\section{TABLE 4.29}

IMPORTANCE TO SCHOOL DEVELOPMENT FOR THE DEAN'S OFFICE TO ASSIST IN FUNDRAISING EFFORTS

$\begin{array}{lrrrr}\text { VALUE } & \text { F } & \% & \text { M } & \text { SD } \\ \text { Very Unimpt (1) } & 0 & 00.0 & & \\ \text { Gen Unimpt (2) } & 1 & 4.0 & & \\ \text { Gen Impt (3) } & 10 & 40.0 & & \\ \text { Very Impt (4) } & 14 & 56.0 & & \\ \text { Missing (9) } & 0 & \underline{00.0} & & \\ & 25 & 100.0 & 3.5 & 0.6\end{array}$

Source: Development Officer Questionnaire (Question 45)

Moreover, in regards to Question 46 concerning how active the dean's office has been in identifying and publicizing substantive institutional activities that may be considered important by the community or prospective contributors, Table 4.30 shows that ten development officers or 40.0 percent of the respondents indicate that the dean's office has been 'very active' (value 4) while nine development officers or 36.0 percent state that it has been 'generally active' (value 3). However, four development officers or 16.0 percent acknowledge that the dean's office has been 'generally inactive' (value 2) in identifying and publicizing substantive institutional activities that may be considered important by the community or prospective contributors. 
TABLE 4.30

DILIGENCE (ACTIVENESS) OF THE DEAN'S OFFICE

IN PUBLIZING SCHOOL ACTIVITIES

\begin{tabular}{lrrrr} 
VALUE & F & $\%$ & M & SD \\
\hline Very inactive (1) & 1 & 4.0 & & \\
Gen Inactive (2) & 4 & 16.0 & & \\
Gen Active (3) & 9 & 36.0 & & \\
Very Active (4) & 10 & 40.0 & & \\
Missing (9) & 1 & 4.0 & & \\
& 25 & 100.0 & 3.2 & 0.9
\end{tabular}

Source: Development Officer Questionnaire (Question 46)

Be that as it may, in response to Question 48 regarding the emphasis placed on the amount of school development office time or money expended on improving the school's public image, Table 4.31 shows that only five development officers or 20.0 percent of the respondents place 'heavy emphasis' (value 4 ) on development time or money spent on improving their school's image. Interestingly, slightly less than one-half, twelve development officers or 48.0 percent of the respondents, place 'moderate emphasis' (value 3) and seven development officers or 28.0 percent place 'minimum emphasis' (value 2) on the amount of school development time or money expended. 
TABLE 4.31

EMPHASIS ON THE IMPROVEMENT

OF THE SCHOOL'S PUBLIC IMAGE

\begin{tabular}{lrrrr} 
VALUE & F & $\%$ & M & SD \\
\hline No Emphasis (1) & 1 & 4.0 & & \\
Min Emphasis (2) & 7 & 28.0 & & \\
Mod Emphasis (3) & 12 & 48.0 & & \\
Hvy Emphasis (4) & 5 & 20.0 & & \\
Missing (9) & $\underline{0}$ & $\underline{00.0}$ & & \\
& 25 & 100.0 & 2.8 & 0.8
\end{tabular}

Source: Development Officer Questionnaire (Question 48)

Furthermore, the development officers' reply to Question 54 concerning the emphasis placed on the amount of time or money spent on personal visits by the development officer to the school's fund raising efforts, Table 4.32 displays that ten development officers or 40.0 percent of the respondents place 'heavy emphasis' (value 4) and ten development officers or 40.0 percent place 'moderate emphasis' (value 3 ) on the amount of time or money spent on personal visits by the school development officer to fund raising activities. 
TABLE 4.32

EMPHASIS ON PERSONAL VISITS BY THE SCHOOL DEVELOPMENT OFFICER

\begin{tabular}{lrrrr} 
VALUE & F & $\%$ & M & SD \\
\hline & & & & \\
No Emphasis (1) & 0 & 00.0 & & \\
Min Emphasis (2) & 5 & 20.0 & & \\
Mod Emphasis (3) & 10 & 40.0 & & \\
Hvy Emphasis (4) & 10 & 40.0 & & \\
Missing (9) & $\ell$ & $\underline{00.0}$ & & \\
& 25 & 100.0 & 3.2 & 0.8
\end{tabular}

Source: Development Officer Questionnaire (Question 54)

Also, it is of interest to note that of the twenty-five development officers responding to Question 53 concerning the importance of personal visits to the school's fund raising efforts, Table 4.33 shows that twenty-one development officers or 84.0 percent of the respondents rate personal visits as being 'very important' (value 4) and three development officers or 12.0 percent give it a 'generally important' (value 3) mark. Conceivably, personal visits are held in high regard by the development officer respondents and the data imply that these development officers perceive the school's public relations as noteworthy and personal visits to be the most effective technique in facilitating fund raising. 
TABLE 4.33

IMPORTANCE OF PERSONAL VISITS TO THE SCHOOL'S

FUNDRAISING EFFORTS

$\begin{array}{lrrrr}\text { VALUE } & \text { F } & \% & \text { M } & \text { SD } \\ \text { Very Unimpt (1) } & 0 & 00.0 & & \\ \text { Gen Unimpt (2) } & 1 & 4.0 & & \\ \text { Gen Impt (3) } & 3 & 12.0 & & \\ \text { Very Impt (4) } & 21 & 84.0 & & \\ \text { Missing (9) } & \underline{0} & \underline{000} & & \\ & 25 & 100.0 & 3.8 & 0.5\end{array}$

Source: Development Officer Questionnaire (Question 53)

Concerning the emphasis placed on the amount of time or money expended by the school development office on prospect research, Table 4.34 displays that virtually one-half, twelve development officers or 48.0 percent of the respondents, acknowledge that only a 'minimum emphasis' (value 2) is placed on prospect research; while seven development officers or 28.0 percent state their schools place a 'moderate emphasis' (value 3) and six development officers or 24.0 percent of the respondents claim a 'heavy emphasis' (value 4) is placed on the amount of time or money expended by the school on prospect research. Evidently, the greater number of schools of dentistry commit a minimal amount of time or money on prospect research and potential donor identification. 
TABLE 4.34

EMPHASIS ON PROSPECT RESEARCH

\begin{tabular}{lrrrr} 
VALUE & F & $\%$ & M & SD \\
\hline No Emphasis (1) & 0 & 00.0 & & \\
Min Emphasis (2) & 12 & 48.0 & & \\
Mod Emphasis (3) & 7 & 28.0 & & \\
Hvy Emphasis (4) & 6 & 24.0 & & \\
Missing (9) & $\underline{0}$ & $\underline{0.0}$ & & \\
& 25 & 100.0 & 2.8 & 0.8
\end{tabular}

Source: Development Officer Questionnaire (Question 51)

Interestingly and possibly a consequence of the apparent lack of emphasis placed on the amount of time or money expended by the school on prospect research, the effectiveness of prospect research, as exhibited in Table 4.35, is conceded to be 'generally ineffective' (value 2) by eight development officers or 32.0 percent of the respondents; while just twelve development officers or 48.0 percent rate it as being 'generally effective' (value 3 ) and only four development officers or 16.0 percent of the respondents recognize the effectiveness of prospect research as being 'very effective' (value 4).

TABLE 4.35

EFFECTIVENESS OF PROSPECT RESEARCH

\begin{tabular}{lrrrr} 
VALUE & F & $\%$ & M & SD \\
\hline Very Ineffct (1) & 1 & 4.0 & & \\
Gen Ineffct (2) & 8 & 32.0 & & \\
Gen Effct (3) & 12 & 48.0 & & \\
Very Effct (4) & 4 & 16.0 & & \\
Missing (9) & 0 & $\underline{00.0}$ & & \\
& 25 & 100.0 & 2.8 & 0.8
\end{tabular}

Source: Development Officer Questionnaire (Question 49) 
The development officer respondents were asked to rate the importance of five criteria in establishing fund raising goals. Table 4.36 compares the relative importance of these criteria as perceived by the school development officer. 'Higher than previous years goal' is given the highest mean score of 3.6, followed closely by 'realistic expectations' with a mean score of 3.6. Sixteen development officers or 64.0 percent of the respondents rate the former as 'very important' (value 4) and thirteen development officers or 52.0 percent give the latter this same high rating of importance. 'Major effort based on an anniversary' is rated third with a mean score of 3.4. Eleven development officers or 44.0 percent of the respondents judge this criterion as 'very important' (value 4) and six development officers or 24.0 percent gauge it as being 'generally important' (value 3). 'Significantly higher than previous years goals' is ranked as fourth with a low mean score of 2.5 while 'inflation plus $5-10 \%$ ' is a distant fifth with the lowest mean score of 2.2. 
TABLE 4.36

IMPORTANCE OF FUND RAISING CRITERIA

DISTRIBUTION

CRITERIA

MEAN

VI G

GU

VU

$\%$

Higher Than Previous

Years Goal

3.6

16

8

1

0

$25 \quad 100.0$

Significantly Higher Than

Previous Years Goals

2.5

$\begin{array}{lll}9 & 9 & 1\end{array}$

20

80.0

Inflation Plus

5-10\%

0

7

8

3

18

72.0

Major Effort Based On

An Anniversary

(or the like)

3.4

11

6

3

0

20

80.0

Realistic

Expectation

3.6

13

7

1

0

21

84.0

Responses range from Value $4=$ Very Important (VI) to Value $1=$ Very Unimportant (VU)

Source: Development officer Questionnaire (Question 55)

The use of volunteer workers by the school's development office to solicit funds is perceived as a positive method of fund raising by a preponderance of development officer respondents. While only two development officers or 8.0 percent of the respondents replied negatively to the question, twenty-three development officers or 92.0 percent of the respondents acknowledge affirmatively that volunteers are very much involved in the school's fund raising efforts. 
Q 57 Does the school development office use volunteers to solicit funds?

\begin{tabular}{llr} 
& F & $\%$ \\
\cline { 2 - 3 } Yes & 23 & 92.0 \\
No & 2 & 8.0 \\
Missing & $\underline{0}$ & $\underline{0.0}$ \\
& 25 & 100.0
\end{tabular}

Table 4.37 compares the relative effectiveness of certain methods and techniques in optimizing the school's fund raising efforts as perceived by the development officer respondents. The category, 'personal visits', is discerned to be the most effective method of enhancing the school's fund raising programs. Eighteen development officers or 72.0 percent of the respondents assign 'personal visits' the highest rating (value 4) and four development officers or 16.0 percent give it the second highest rating (value 3 ) with a mean score of 3.7.

Another category, 'phoning by alumni', succeeds to the second most effective method with a mean score of 3.6, followed closely by 'personalized letters' with a mean score of 3.5 as another effective fund raising method. Interestingly, twenty-two development officers or 88.0 percent of the respondents classify 'personalized letters' as an effective fund raising method with only two development officers or 8.0 percent not responding to the query. Additionally, seventeen development officers or 68.0 percent of the respondents categorize 'phoning by alumni' as being effective along with seven development officers or 28.0 percent who did not respond to the question.

The following methods and techniques, which are closely rated as to their effectiveness in optimizing fund raising are listed in order of their effectiveness with their mean score noted:

Personal Visits

- Phoning By Alumni

- Personalized Letters
3.7

3.6

3.5 
- Special Gift Program

- Suggested Gift Amount

- Designated Gifts

. Phoning By Students

. Class Reunion Giving

- Prospect Research

- Printed Brochures

- Organized Groups of Friends

The other remaining categories receiving a rating under the mean score of 3.0 are listed in descending order of effectiveness:

- Class Agent System

- Case Statement

- Annual Themes

- Computerized Letters

- Outside Professional Counsel

. Humor in Printed Material
2.9

2.9

2.7

2.5

2.4

2.1

It is of interest to note that a majority of development officer respondents (eighteen development officers or 72.0 percent) did not respond to the query regarding the use of outside professional fund raising counsel. Perhaps the relatively low number of respondents (two development officers or 8.0 percent) using outside fund raising counsel may reflect a school's inability to afford the cost of outside counsel or perhaps it may be a reflection of the marginal emphasis placed on the importance of advancement activities by some schools of dentistry.

Also of note is the limited use of the computerized letters as a fund raising technique which suggest that the development officer respondents perceive this method of fund raising as the least effective, corroborating the impressive consequences of personalized solicitation through personal visits as witnessed by a majority of the respondents. 
TABLE 4.37

EFFECTIVENESS OF FUND RAISING METHODS AND TECHNIQUES

DISTRIBUTION

$\begin{array}{lccccccr}\text { METHODS } & \text { MEAN } & \text { VE } & \text { GE } & \text { GI } & \text { VI } & \text { F } & \% \\ \begin{array}{l}\text { Printed } \\ \text { Brochures }\end{array} & 3.0 & 4 & 13 & 4 & 0 & 21 & 84.0\end{array}$

Computerized

Letters

2.5

2

$7 \quad 8$

$2 \quad 19$

76.0

Personalized

Letters

3.5

12

101

23

92.0

Humor in

Printed Material

2.1

3

$\begin{array}{lll}2 & 2 & 7\end{array}$

28.0

Annual

Themes

2.7

2

6

4

13

52.0

Suggested

Gitt Amounts

3.4

$10 \quad 11 \quad 1$

$22 \quad 88.0$

Designated

Gifts

3.3

$8 \quad 10 \quad 2$

0

$20 \quad 80.0$

Class Agent

System

2.9

4

3

14

56.0

Class Reunion

Giving

3.1

7

3

5

0

$15 \quad 60.0$ 
(cont'd.)

\begin{tabular}{llllllll} 
& \multicolumn{7}{c}{ DISTRIBUTION } \\
METHODS & MEAN & VE & GE & GI & VI & F & $\%$ \\
$\begin{array}{l}\text { Phoning By } \\
\text { Students }\end{array}$ & 3.2 & 7 & 10 & 1 & 1 & 19 & 76.0
\end{tabular}

Phoning By

Alumni

3.6

12

$\begin{array}{lll}5 & 0 & 1\end{array}$

$18 \quad 72.0$

Personal

Visits

3.7

$4 \quad 1$

0

$23 \quad 92.0$

Special Gift

Program

3.5

$\begin{array}{lll}9 & 10 & 0\end{array}$

0

$19 \quad 76.0$

Outside Professional

Counsel

2.4

$2 \quad 0 \quad 4$

1

7

28.0

Prospect

Research

3.1

61

103

1

$20 \quad 80.0$

Case

Statements

2.9

2

9

2

1

$14 \quad 56.0$

Organized

Groups of Friends

3.0

310

$\begin{array}{lll}10 & 1 & 1\end{array}$

$15 \quad 60.0$

Responses range from Value $4=$ Very Effective (VE) to Value $1=$ Very Ineffective (VI).

Source: Development Officer Questionnaire (Question 58) 
As reflected in Table 4.38, funds raised from private sources can be designated for many uses. In response to Question 59, the school development officers evaluated the attractiveness of various gift-uses in positively influencing donors to contribute. The attractiveness of scholarships as a gift-use in inspiriting potential donors to contribute is perceived by the development officer respondents to rate the highest with a mean score of 3.5 of a maximum possible value of 4.0 .

The following gift-use categories, which are closely evaluated as to their attractiveness in favorably influencing donors to contribute, are listed in order of their attractiveness with their mean score noted:

- Scholarships

- Specific Academic Areas

- Special Programs

. Gift-In-Kind

- Endowment

- Capital Projects

The remaining gift-use categories receiving a rating under the mean score of 3.0 are listed in descending order of attractiveness with their mean score noted:

- Endowed Chairs

- Faculty Projects

. Research

- Library Acquisitions
2.9

2.7

2.4

1.8

Research is rated as one of the least attractive gift-use category, with a low mean score of 2.4. In addition, no more than two development officers or 8.0 percent of the respondents evaluate research, as a gift-use, to be 'very attractive' to potential donors. 
TABLE 4.38

ATTRACTIVENESS OF VARIOUS GIFT-USES TO DONORS

\begin{tabular}{|c|c|c|c|c|c|c|c|}
\hline & \multicolumn{7}{|c|}{ DISTRIBUTION } \\
\hline & MEAN & VA & GA & GU & ve & $\mathrm{F}$ & $\%$ \\
\hline Scholarships & 3.5 & 8 & 14 & 2 & 0 & 24 & 96.0 \\
\hline Endowments & 3.1 & 4 & 17 & 0 & 1 & 22 & 88.0 \\
\hline
\end{tabular}

Specific

Academic Areas

3.4

$12 \quad 1 \quad 0$

$22 \quad 88.0$

Library

Acquisitions

1.8

$3 \quad 8$

$17 \quad 68.0$

Endowed

Chairs

2.9

5

$\begin{array}{lllll}8 & 6 & 1 & 20 & 80.0\end{array}$

Faculty

Projects

2.7

2

9

7

0

$18 \quad 72.0$

Special

Programs

3.2

$21 \quad 84.0$

Capital

Projects

3.0

$7 \quad 10$

2

3

$22 \quad 88.0$

Gitt-in-Kind

3.1

$\begin{array}{llll}4 & 14 & 2 & 0\end{array}$

$20 \quad 80.0$

Research

2.4

2

$7 \quad 8$

3

$20 \quad 80.0$

Responses range from Value $4=$ Very Attractive (VA) to Value $1=$ Very Unattractive (VU).

Source: Development Officer Questionnaire (Question 59) 
The following comments made by the development officer respondents regarding their perception of their school's advancement activities provide insight into the type of fund raising strategy they consider the school's most successful and the most outstanding features of the school's total fund raising program:

- Successful Strategy - The dean's innate ability to relate to individuals and to earn their respect and trust has resulted in several major unrestricted gifts, usually deferred and coupled with a binding pledge agreement. This type of fund raising has resulted in the highest totals. For broad based participation, college administered and university implemented phonathons and direct mail programs do very well.

\section{Outstanding Feature:}

- Dean's ability to participate in fund raising;

- Dean's support of development function;

- University support: resources, direction, cooperation;

- Confidence in management by dean;

- Staff are well acquainted with many facets of college's operation, not just development; and

- College enjoys high morale which is reflected in faculty who support development initiatives.

- Successful Strategy - Endowment campaigns seem to have the most success... organized by a volunteer structure (i.e., committee with various sub-committees as needed). The reasons these are more successful than capital projects is - as a state (public) school donors/alumni believe that "bricks \& mortar" should be paid by state dollars, and it is the alumni's role to endow the school with funds for chairs, professorships, scholarships (i.e., named funds). Deferred gifts are becoming more active and we will continue to promote this vehicle for gift giving. 
Outstanding Feature - Involvement of alumni in the development program. This has generated excitement as well as dollars for the school. We are also doing a better job of planning and recruiting volunteer leadership as well as faculty.

- Successful Strategy - Annual giving seems to be the most popular with donor, and therefore the most successful. Annual giving becomes a routine that the donor expects and is conditioned to giving a specified amount at the same time each year. It is easiest on the donor - therefore, it works.

Outstanding Feature - The love for the dental profession, and the chance to "give something back" appear to be the most effective words in encouraging dentists to make donations. Therefore, our personal solicitations are the most-outstanding feature, because they create lasting good will and good feelings for both the donor and the fund raiser.

- Successful Strategy - Deferred gift strategy is the most successful because it has the potential for raising greater sums of money for the endowment than any other source. The deferred gifts instruments (i.e., trusts, life insurance, bequests, et al.) have added features that you are able to "hook" the donor's interests with.

Outstanding Feature - Involvement of the alumni in the school's programs. An active alumni association combined with annual social events (i.e., reunions every five years and donor recognition society gatherings) help to build and sustain loyalty and gift support. 
- Successful Strategy - The Phonathon has been most effective. It doubles the alumni dollars and donor base. This year we'll move on to major gifts and personal soliciations.

Outstanding Feature - Nothing yet, but we're getting there

- Successful Strategy - We focus on a new donor giving club which is also a membership organization.

Outstanding Feature - There are none. The school has existed for over $(100+)$ years yet nothing has been done to involve alumni in the life of the school. There is not even an alumni newsletter or magazine that supports the efforts. This program has a long way to go before it will be competitive.

Finally, the data seem to suggest that certain academic activities of schools of dentistry are the most influential stimuli to gift-giving in schools which are academically attuned as well as student oriented. Furthermore, the indispensability of research for schools of dentistry may be misunderstood by the donor constituencies or perhaps may not be an area of emphasis by the development office. Who knows but that the need for research may reflect more the bias of the school's CEO and faculty rather than its position of attractiveness among potential donors. 


\section{DEANSURVEY}

DEMOGRAPHIC INFORMATION

The following tables display demographic data regarding the dean respondents. The source of the data was the dean questionnaire, Questions 22a through 22e. Of the thirty-two dean respondents, thirty or 93.8 percent identified themselves as males and nineteen or 59.4 percent regarded themselves as Caucasian. Two deans or 6.3 percent did not respond to the gender category and thirteen or 40.6 percent did not respond to the ethnicity listing.

The variable, age, produced the following configuration. The youngest deans, those below the age of forty-five, comprised 3.1 percent $(n=1)$ while those between the ages of forty-six to forty-nine were 24.8 percent $(n=8)$ of the respondents. Another 18.8 percent $(n=6)$ of the dean respondents were made up of the group between the ages of fifty to fifty-three and 31.4 percent $(n=10)$ reported ages from fifty-five to fifty-nine. Lastly, 9.4 percent $(n=3)$ were between sixty-five to sixty-six. 12.5 percent $(n=4)$ did not respond. The ungrouped data regarding age showed that deans had a mean age of 53.6 years.

TABLE 4.39

ETHNICITY: DEANS
TABLE 4.40

GENDER: DEANS

$\begin{array}{lrrlrrr} & \text { E } & \% & & \text { E } & \% \\ \text { Caucasian } & 19 & 59.4 & \text { Male } & 30 & 93.8 \\ \text { Hispanic } & 0 & 00.0 & \text { Female } & 0 & 00.0 \\ \text { African-Am } & 0 & 00.0 & \text { Missing } & 2 & 6.3 \\ \text { Asian-Pac } & 0 & 00.0 & & 32 & 100.0 \\ \text { Others } & 0 & 00.0 & & & \\ \text { Missing } & 13 & 40.6 & & & \\ & 32 & 100.0 & & & \end{array}$


TABLE 4.41

AGE: DEANS

$\begin{array}{lrr}\text { YEARS } & F & \% \\ 43 & 1 & 3.1 \\ 46-49 & 8 & 24.8 \\ 50-53 & 6 & 18.8 \\ 55-59 & 10 & 31.4 \\ 65-66 & 3 & 9.4 \\ \text { Missing } & 4 & 12.5 \\ & 32 & 100.0\end{array}$

Mean 53.6

In response to Question 22d, 'How long have you been dean at this school?', Table 4.42 shows that sixteen deans or 50.0 percent of the respondents stated to have served less than four years while ten deans or 31.3 percent acknowledged to have experienced five to nine years as dean. Three dean respondents or 9.4 percent claimed ten to fourteen years and three deans or 9.4 percent of the respondents declared to have completed twenty to twenty-four years as dean at their school. The responding deans registered a mean of 6.6 which suggests they have experienced approximately seven years as dean at their school. 
TABLE 4.42

TENURE OF THE DEANS AT THEIR CURRENT SCHOOL

\begin{tabular}{crr} 
YEARS & $F$ & $\%$ \\
\hline $1-4$ & 16 & 50.0 \\
$5-9$ & 10 & 31.3 \\
$10-14$ & 3 & 9.4 \\
$15-19$ & 0 & 00.0 \\
$20-24$ & 3 & 9.4 \\
Missing & $\ell$ & 00.0 \\
& 32 & 100.0
\end{tabular}

Mean 6.6

When identifying their previous administrative experience in a school of dentistry, in response to Question 22e, Table 4.43 shows that of the thirty-two respondents reporting their experiences as dean, fourteen or 43.8 percent of the respondents served less than four years while seven or 21.9 percent experienced five to nine years as dean. Four deans or 12.5 percent of the respondents reported serving ten to fourteen years while two deans or 6.3 percent acknowledged fifteen to nineteen years and two deans or 6.3 percent of the respondents reported to have experienced twenty to twenty-four years as dean. Three deans or 9.4 percent did not respond. Moreover, the responding deans scored a mean of 7.2 which suggests the average dean has experienced approximately seven years in administrative experience in a school of dentistry. 
TABLE 4.43

YEARS OF PRIOR ADMINISTRATIVE EXPERIENCE AS DEAN

$\begin{array}{crr}\text { YEARS } & F & \% \\ 1-4 & 14 & 43.8 \\ 5-9 & 7 & 21.9 \\ 10-14 & 4 & 12.5 \\ 15-19 & 2 & 6.3 \\ 20-24 & 2 & 6.3 \\ \text { Missing } & 3 & 9.4 \\ & 32 & 100.0\end{array}$

Mean 7.2

In relating their previous administrative experience as assistant or associate deans, Table 4.44 shows that eleven deans or 34.4 percent of the respondents said they had served less than four years while five deans or 15.6 percent reported five to nine years. Three deans or 9.4 percent of the respondents reported to have experienced ten to fourteen years and one dean or 3.1 percent acknowledged twenty to twenty-four years. Twelve deans or 37.5 percent did not respond. The mean of 5.8 suggests approximately six years of prior administrative experience as an assistant or associate dean. 
TABLE 4.44

YEARS OF PRIOR ADMINISTRATIVE EXPERIENCE AS ASSISTANT/ASSOCIATE DEAN

$\begin{array}{ccc}\text { YEARS } & F & \% \\ 1-4 & 11 & 34.4 \\ 5-9 & 5 & 15.6 \\ 10-14 & 3 & 9.4 \\ 15-19 & 1 & 3.1 \\ 20-24 & 0 & 00.0 \\ \text { Missing } & 12 & 37.5 \\ & 32 & 100.0\end{array}$

Mean 5.8

In responding to the question concerning their previous administrative experience as head of a department or department chairperson, seven deans or 21.9 percent of the respondents reported less than four years exposure and seven deans or 21.9 percent encountered five to nine years. Six deans or 18.8 percent of the respondents experience ten to fourteen years while three deans or 9.4 percent professed to have served fifteen to nineteen years as head of a department. Nine deans or 28.1 percent did not respond and the mean was 8.2 which suggests eight years of prior administrative experience as department chairperson. 
TABLE 4.45

YEARS OF PRIOR ADMINISTRATIVE EXPERIENCE AS DEPARTMENT CHAIRPERSON

$\begin{array}{ccr}\text { YEARS } & F & \% \\ 1-4 & 7 & 21.9 \\ 5-9 & 7 & 21.9 \\ 10-14 & 6 & 18.8 \\ 15-19 & 3 & 9.4 \\ 20-24 & 0 & 00.0 \\ \text { Missing } & 9 & 28.1 \\ & 32 & 100.0\end{array}$

Mean 8.2 


\section{DEVELOPMENT OFFICERS SURVEY}

DEMOGRAPHIC INFORMATION

The following tables evince demographic data pertaining to the development officer respondents. The source of the data was the Development Officer Questionnaire, Questions 63a through 63e. Of the twenty-five development officer respondents, fourteen or 56.0 percent identify themselves as females and eight or 32.0 percent name themselves as males. Additionally, sixteen development officers or 64.0 percent of the respondents regard themselves as Caucasian. However, three development officers or 12.0 percent did not respond to the gender category and nine development officers or 36.0 percent did not respond to the ethnicity listing.

The variable, age, produced the following configuration. The youngest development officers, those below the age of thirty, comprise 4.0 percent $(n=1)$ while those between the ages of thirty to thirty-eight are 36.0 percent $(n=9)$ of the respondents. Another 32.0 percent $(n=8)$ of the development officer respondents are made up of the group between the ages of forty to forty-nine and 12 percent $(n=3)$ report ages from fifty and fifty-eight years. Interestingly, the oldest development officer (one development officer or 4.0 percent of the respondents) acknowledges to be 70 years old. Three development officers or 12.0 percent did not respond to the query. The ungrouped data regarding age showed that the development officer respondents have a mean age of 41.5 years. 
TABLE 4.46

ETHNICITY: DEVELOPMENT OFFICERS

$\begin{array}{lrrlrr} & \text { F } & \% & & \underline{F} & \% \\ \text { Caucasian } & 16 & 64.0 & \text { Male } & 8 & 32.0 \\ \text { Hispanic } & 0 & 00.0 & \text { Female } & 14 & 6.0 \\ \text { African-Am } & 0 & 0.0 & \text { Missing } & \underline{3} & \underline{12.0} \\ \text { Asian-Pac } & 0 & 00.0 & & 25 & 100.0 \\ \text { Others } & 0 & 00.0 & & & \\ \text { Missing } & \underline{9} & \underline{36.0} & & & \\ & & 100.0 & & & \end{array}$

TABLE 4.48

AGE: DEVELOPMENT OFFICERS

$\begin{array}{lrr}\text { AGE } & F & \% \\ 27 & 1 & 4.0 \\ 30-38 & 9 & 36.0 \\ 40-49 & 8 & 32.0 \\ 50-58 & 3 & 12.0 \\ 70 & 1 & 4.0 \\ \text { Missing } & 3 & 12.0 \\ & 25 & 100.0\end{array}$

Mean 41.5
T ABLE 4.47

GENDER: DEVELOPMENT OFFICERS

$\%$
0
0
0


nine years as the school development officer. The longest serving respondent (one development officer or 4.0 percent) claims more than ten but less than fourteen years as the school development officer. One development officer or 4.0 percent did not respond. The responding development officer registered a mean of 3.7 which suggests that they have experienced approximately four years as development officer at their school.

TABLE 4.49

TENURE OF THE DEVELOPMENT OFFICERS AT THEIR CURRENT SCHOOL

\begin{tabular}{ccr} 
YEARS & $F$ & $\%$ \\
\hline $1-4$ & 19 & 76.0 \\
$5-9$ & 4 & 16.0 \\
$10-14$ & 1 & 4.0 \\
$15-19$ & 0 & 00.0 \\
$20-24$ & 0 & 00.0 \\
Missing & 1 & 40 \\
& 25 & 100.0
\end{tabular}

Mean 3.7

Additionally, Table 4.50 shows that of the twenty-five respondents reporting their previous administrative experience as a development officer in a school of dentisrty, seventeen development officers or 68.0 percent of the respondents served less than four years while two development officers or 8.0 percent experienced five to nine years. Two development officers or 8.0 percent of the respondents that held the longest administrative term claim to have experienced up to fourteen years as a development officer in a school of dentistry. One development officer or 4.0 percent did not respond to the question. Furthermore, the mean of 3.4 suggests approximately three years of prior administrative experience as a development officer in a school of dentistry. 
TABLE 4.50

YEARS OF PRIOR ADMINISTRATIVE EXPERIENCE AS A DEVELOPMENT OFFICER

\begin{tabular}{ccr} 
YEARS & $F$ & $\%$ \\
\hline $1-4$ & 17 & 8.0 \\
$5-9$ & 2 & 8.0 \\
$10-14$ & 2 & 8.0 \\
$15-19$ & 0 & 00.0 \\
$20-24$ & 0 & 00.0 \\
Missing & 1 & 4.0 \\
& 25 & 100.0
\end{tabular}

Mean 3.4 


\section{DEAN INTERVIEW}

\section{DEVELOPMENT OFFICER INTERVIEW}

This aspect of the investigation identified specific factors perceived to be helpful in enhancing the school's fund raising efforts. The contextual framework for this analysis is guided by the data obtained from the personal interviews as well as the data collected from the follow-up interview guide (see Appendices I and J). Since this phase of the research was designed to collect detailed and complimentary information to provide further clarity to the questionnaire responses, the samples were limited to the deans and development officers of the five California schools of dentistry. Consequently, the analysis yields suggestive rather than statistically significant findings and it is tempered by those limitations.

California school of dentistry deans and development officers were asked to rate the industriousness of their school in the performance of various tasks to facilitate the school's fund raising efforts. The following provides a comparison of their perceptions of the diligence of those institutions. Each quantitative item on the interview guide was coded for direction and magnitude of item meaning. To code activeness, successfulness, or helpfulness, for particular items, four-point Likert scales were used:

$\begin{array}{ll}\text { Very inactive/unsuccessful/unhelpful } & 1 \\ \text { Generally inactive/unsuccessful/unhelpful } & 2 \\ \text { Generally active/successful/helpful } & 3 \\ \text { Very active/successful/helpful } & 4\end{array}$

Of the five California deans, four deans responded to the interview guide and of the five development officers, four development officers responded. Not every respondent answered every question contained in the interview guide. As a result, the number of respondents for a given question may vary. All percentages 
reported are adjusted for these missing data. Unreliable or unusable data were so coded and not analyzed.

Q1 How active has the school been in performing each of the following tasks?

- Having the development officer visit major funding prospects?

. Having the dean visit major funding prospects?

- Submitting proposals to major funding prospects?

- Making follow-up contacts with a major funding prospect after submitting a proposal?

- Doing follow-up work on proposals rejected by major funding prospects?

In response to $\mathrm{Q1}$, two of the dean respondents rate the school development officer as being 'very active' (value 4) in visiting major funding prospects and as the individual most likely to be responsible for the first approach to a major funding prospect. Moreover, the data indicate that no respondent to this query identified the dean as the individual selected by their institution to make the first contact with a prospective donor. A majority of the dean respondents (three deans) acknowledge that the dean is 'generally inactive' (value 2) in visiting major funding prospects.

The written 'comments' revealed that on a 'formal' basis, deans are not requested to represent their school in a fund raising capacity. They will, however, on an 'informal' basis make positive inroads into establishing favorable contacts with major funding prospects and thereby opening the door for the school development officer. Overall, the data imply that the individual responsible for the initial contact with a major funding prospect will be the school development officer.

California schools of dentistry development officers rank visiting major funding prospects as the activity they are most active in performing. The development officers were solicited to comment on their responses. The following quote provides an insight into an important fund raising process: 
A major solicitation requires the proper preparation and follow-up work in order to satisfy the donor. The leading academician is necessary to espouse the institutional support for a project; and the development officer is necessary to move the meeting along in the right direction, ask and respond to specific donor financial questions, and in some cases - make the ask - if the dean doesn't do it.

It is of interest to note that in general, the dean respondents evaluate submitting proposals to a major funding prospect as the funding activity their school is generally inactive in performing. The respondents were asked to comment on their responses. The following quote provides a general overview of why the school is or is not active in submitting proposals to major funding prospects:

Personal contact has resulted in most of our major gifts. We have submitted very few written proposals to major donors. Most of our solicitations are verbal mainly because we know our major donors well.

As a rule, the data imply an agreement among the respondents concerning the extent of the different activities in seeking financial support for their institutions. The dean and development officer respondents perceived their schools to be most active in two activities:

. Having development officers visit major funding prospects; and

- Making follow-up contact with major funding prospects on submitted proposals.

Q2 How successful has the school been in each of the following:

- Obtaining grants for the proposals submitted to funding prospects?

- Finding out why a proposal was not funded by funding prospect?

- Obtaining grants for the amount requested in the proposal? 
In response to $\mathrm{Q} 2$, the dean respondents were invited to evaluate their school's successfulness in obtaining grants. The data reveal that for the overall results, the greater number of dean respondents evaluate their school fund raising efforts in obtaining grants and in acquiring grants for the amount requested as 'generally successful' (value 3). 'Obtaining grants' is closely followed by 'obtaining grants/amount requested' and finding out 'why proposal was not funded.' Of note, one of the dean respondents reported his school's effort in obtaining grants as 'very successful' (value 4) and one dean claimed obtaining grants for the amount requested also as 'very successful' (value 4). Moreover, no dean respondent considered their school's effort in obtaining grants as 'very unsuccessful' (value $1)$.

Q2 also examines the issue of how development officer respondents perceive the success of their fund raising efforts in obtaining grants for the proposals submitted to funding prospects. The following quote provides a succinct overview of a development officer respondent's caveat on foundation, corporation and individual fund raising:

- From foundations, very successful if we have volunteer connection.

- From corporations, not very successful even with a volunteer.

- From individuals, very successful whether by staff, volunteer, or dean/faculty.

. We always ask for what we need. Due to foundation guidelines, we sometimes receive less than requested.

As a whole, the data suggest that the dean and development officer respondents perceived their schools to be successful in obtaining grants for the proposals submitted to funding prospects. However, the respondents did not single out an activity as indicative of success in obtaining the grants. 
Q3 How helpful would you say the following institutional features have been to the school in its attempt to obtain philanthropic support from 1987-88 to 1990-91?

- School's geographic location?

- School's university affiliation?

- School's historical background/development?

- School having a balanced budget?

- Level of school's indebtedness?

- School's strategic plan?

. Size of school's enrollment?

Q3 identifies the institutional characteristics and/or attributes that may be considered most important in the marketing of an institution to prospective donors. The following examines the issue of how the dean and development officer respondents perceive the success of their fund raising efforts during the academic years $1987-88$ to $1990-91$.

The respondents acknowledge certain institutional features have been helpful in securing philanthropic support and agree that the two most helpful institutional features were 'university affiliation' and 'historical background/development' of their schools. According to one of the respondents, "our alumni who are our major donors feel a great deal of pride in and gratitude for their education and their school."

However, it is interesting to note that the dean and development officer respondents differed as to the importance or helpfulness of 'geographic location' and 'strategic planning' in securing philanthropic support for their schools. Analysis indicates that two of the dean respondents recognized that the geographic location of their schools has been 'very helpful' (value 4) and the other half of the dean respondents acknowledged that their school location has been 'generally helpful' (value 3) in securing support. Nevertheless, only one of the development officer respondents felt that the geographic location has been 'very 
helpful' (value 4) and one has found the school location to be 'generally helpful' (value 3 ) in the school's fund raising efforts.

In reporting the institutional features the dean and development officer respondents considered to be most helpful in obtaining philanthropic support for their schools, one of the development officer respondents conceded that strategic planning is 'generally helpful' (value 3 ) in this regard. However, the majority (three) of the dean respondents declared that strategic planning is 'generally helpful' (value 3 ) in enhancing the school's advancement activities.

In the main, the data suggest that both the dean and development officer respondents perceived four institutional features to be most helpful in securing philanthropic support:

- Geographic location;

- University affiliation;

- Balanced budget; and

- Indebtedness.

Q4 How helpful have the following development office features been to the school in its attempt to obtain philanthropic support from 1987-88 to 1990-91?

- Tenure of the senior development officer?

- Professional background of the senior development officer?

- Number of full-time staff employed by the development office?

- Amount of time the development staff spends researching funding prospects?

- Strategic planning done by the development office?

- Number of proposals submitted to funding prospects?

- Quality of proposals submitted to funding prospects? 
The dean and development officers responding to $Q 4$ give evidence that the tenure and professional background of the school development officer has been most helpful in securing philanthropic support for their schools. According to one of the respondents, "our development officer has been here long enough to become personally involved and acquainted with our major donors. Her knowledge of them and their knowledge of her has been very helpful."

The analysis indicates that strategic planning has become an adopted procedure in the administration of their school's advancement activities. It is of interest to note that the majority of the respondents appear to be aware of the benefits accrued from utilizing strategic planning for the school's fund raising efforts. According to a respondent, "strategic planning provides focus and goal-settting objectives. The more direction we have, the sooner we raise money. ..."

Other development office features dean and development officer respondents felt were generally helpful in their school's advancement activities were full-time development staff and the number and quality of proposals submitted to potential funding prospects. The responses of the development officers make clear that the measure of the school's commitment to development staff is made through the allocation of financial and physical resources for the school's development office as well as personal support for the development officer.

The respondents were asked why they did or did not consider the amount of time the development staff spends researching potential funding prospects and the number and quality of proposals submitted to funding prospects as helpful. The following quote provides a general overview of why a development officer respondent did not feel that the time spent researching potential funding prospects and the number and quality of proposals submitted were helpful features in the school's fund raising efforts, ". . . it has been difficult to match institutional priorities with donor and volunteer interests (dentistry is generally not a sexy-sell)." 
In general, the data imply an accordance among the respondents regarding the following four development office features that were helpful in obtaining philanthropic support for their school:

- Tenure and professional background of the senior development officer;

- Number of full-time development staff;

. Strategic planning; and

. Quality of proposals.

Q5 How often did you, as dean (or as development officer), participate in the following activities in the last academic year?

- Meeting with the development officer (or dean) to discuss a possible grant application by the school?

- Visiting a major funding prospect to make a request for funds?

- Discussing potential sources of philanthropic support with the school's development officer (or dean)?

- Meeting with volunteers to discuss assisting the school with its advancement activities?

The dean and development officer respondents to Q5 were asked to explain why they did or did not consider frequencies and types of activities that they participated in were important for their school's fund raising efforts. The following quotes provide a general overview of why the responses to the query indicate that increased frequencies of meetings were sought:

. Hopefully, we are doing this more than once every 1-3 months.

. I meet with the dean bi-weekly. . . . More meeting time with (the) dean would be more desirable.

. Meet with development official at least weekly. 
Q6 through Q10 (see Appendices I and J) examine key areas of institutional fund raising efforts which required written commentaries by the dean and development officer respondents. The following illustrative comments made by the respondents regarding their perceptions of the school's advancement activities provide insight into their current solicitation efforts:

Q6 What has been your primary role, as dean (or development officer), with the school's fund raising efforts?

\section{Q6/ Dean}

(primary role)

- My primary role has been many face to face meetings (with) and solicitations of donors. I have also made great efforts to become well acquainted with our past donors to keep them closely tied to me as dean and the school.

\section{Q6 / Development Officer}

(primary role)

- My role is to chart the course for fund raising activities for the school; work with the dean to set priorities; involve the dean; visit personally with alumni and major gift prospects.

Q7 What has been your main frustration with the school's fund raising efforts?

\section{Q7 / Dean}

(main frustration)

Support groups; the university not allowing us to solicit major foundations and some major donors. 
Q7 / Development Officer

(main frustration)

- No track record in terms of educating alumni about the needs of the school; school of medicine receives priority attention.

Q8 What have been the outstanding features of fundraising efforts of your school?

Q8 / Dean

(outstanding features)

Close ties with major donors; an active board of counselors; increased interest (in) and number of trusts.

Q8 / Development Officer

(outstanding features)

Annual giving has been a constant though I wouldn't say it has been outstanding.

Q9 What should the school do to improve its ability to obtain philanthropic support?

Q9 / Dean

(improve ability)

More focus on corporations; ... spending more time on fund raising... 
Q9 / Development Officer

(improve ability)

- Better educate alumni and involve them in the process; get the dean out in front of alumni to relay the goals of the school.

Q10 Succinctly describe the role gifts from philanthropic support have played in the life of the school?

Q10 / Dean

(role of gifts)

Our school was built with money from gifts. No facility or department has not benefited from gifts. Our fund raising success is well respected within the university. Our alumni are avidly interested and involved in the school.

Q10 / Development Officer

(role of gifts)

Purchase equipment, teaching tools and materials, scholarships, some faculty development, renovation. There has not been a formal process of setting priorities and going about raising funds for those priorities. We are doing that now! 


\section{SUMMARY OF THE DATA ANALYSIS}

An analysis of the information collected is an integral part of the research process. It should be reviewed in relationship to the needs and characteristics of the institutions as well as the competency of those in charge. The analysis should allow schools of dentistry to determine their institutional strengths. Perhaps, this determination may help those schools assess their relationship with potential donors enabling schools of dentistry to understand what their position is within the arena of fund raising in American higher education. Additionally, the analysis permitted the researcher to address the five main research questions listed in the first chapter of this study.

Five main research questions and additional subquestions were specifically developed to guide the research. The research questions all relate to the advancement activities at selected American schools of dentistry and are addressed by specific questions in the survey instruments. The principal findings based on the data collected and keyed to the research questions are briefly summarized below.

\section{RESEARCHQUESTIONONE}

1. How is fund raising organized for American schools of dentistry? What specific organizational fund raising structures exist within schools of dentistry?

a. Do these schools of dentistry typically have a separate development office?

b. What is the title of the school development officer?

c. What is the reporting relationship? Who has the lead responsibility and to whom do they report?

d. How does this reporting relationship fit into the organization? 
PRINCIPAL FINDINGS

The findings indicate that the majority (sixty-eight percent) of the development officer respondents reported that their schools have a separate development office. Moreover, thirty-two percent of the respondents reported that their development office has been in operation 12 to 16 years and twenty-four percent of the respondents claimed 1 to 6 years of development office operation. Additionally, more than one-half (sixty percent) of the development officer respondents carry the title of Director of Development with the primary responsibility for the school advancement activities and, in most cases, they also carry the functional responsibility for other duties such as alumni affairs and public relations. The twenty-five development officer respondents in the present study indicate that they report to superiors at five different levels. As indicated in the analysis, almost one-half (eleven development officers or 44.0 percent) of the respondents reported directly to the school dean. However, in every case the development officer had direct access and reporting responsibilities to the school dean.

\section{RESEARCHQUESTIONTWO}

2. Within schools of dentistry, what are the major development-related functions (such as annual giving, deferred giving, and capital gifts)?

\section{PRINCIPAL FINDINGS}

Despite the fact that most alumni fund raising programs changed in method and technique over the years, while remaining a year-round endeavor, it was apparent that the annual fund was the core fund raising effort for the majority of American schools of dentistry. Although the alumni were the main thrust in this effort, they were not the only constituency involved. Nearly all the institutions had an annual fund drive, but varied in the manner in which solicitations took place. Moreover, fund raising efforts in annual giving have resulted in the most 
significant dollar increases, and according to one development officer respondent "The annual fund has been our most successful. . . the annual fund is the life line to all other fund raising approaches".

\section{RESEARCHQUESTION THREE}

3. What are the specific management practices relative to planning, policy formulation, evaluation, and records management in the sphere of fund raising?

a. What is the role of the dean relative to planning, policy determination, and solicitation of funds?

b. How does the role of the dean fit into the organization?

c. Is strategic planning or some other identifiable management technique utilized to facilitate fund raising?

\section{PRINCIPAL FINDINGS}

The schools of dentistry contributing to this study offer evidence that strategic planning has become an adopted procedure in the administration of the school as well as a management tool for the school's advancement activities. The majority of the dean respondents (93.8 percent) report that an institution-wide system of strategic planning is utilized at their institution. Moreover, 87.5 percent of the deans acknowledge affirmatively to making use of strategic planning as a management tool for the school's advancement activities. The commitment of personnel and financial resources to the strategic planning process attests to the importance of strategic planning by those charged with the responsibility for the future of American schools of dentistry.

The majority of the development office respondents ( 76.0 pecent) acknowledge affirmatively to making use of an annual development plan while 68.0 percent of the respondents prepare an annual development report. Since the processes for preparing an annual development plan and an annual development report are 
complicated and time consuming procedures, these affirmative responses suggest that the development officers believe such approaches are very important to their school and its advancement activities.

Responsibility for the determination of overall administrative policy for the school's advancement activities is primarily shared by the dean and development officer. The research data concerning the involvement of the dean and the development officer in establishing the overall administration policy for the school's advancement activities revealed that the involvement of the dean, as perceived by the dean respondents, is rated high. However, even though most deans perceive their involvement in policy determination as high with a mean of 3.6 (value of 4.0 being highest), this self-perceived level of involvement was slightly less--for practical purposes no different from--the level of involvement of the development officers whom the deans rated with a mean score of 3.7. Evidently, there is no significant difference between the involvement of the dean and the involvement of the development officer in establishing administrative policies for the school's advancement activities.

The greater number of development officer respondents ( 80.0 percent) regard themselves as very involved in evaluating their school's advancement activities. The development officer respondents who indicated that they prepare the annual development plan and the annual development report also rated themselves as most involved in evaluating the results of their efforts. They are followed in involvement by the dean. In reference to the various criteria for evaluating advancement activities, the development officer respondents were asked to rate the importance of four criteria. The criterion, 'total funds raised', is rated the highest, followed closely by the 'number of contributors', and the 'percent increase in funds', respectively. The 'number of volunteer workers' placed a distant fourth.

The development officer has primary responsibility for records management with nineteen development officers or 76.0 percent of the development officer 
respondents performing an analysis of prior giving on an as needed basis while two development officers or 8.0 percent conduct a monthly review and four development officers or 16.0 percent execute an annual inquiry.

\section{RESEARCHQUESTIONFOUR}

4. What are the major sources (for instance, alumni, corporations, foundations) from which American schools of dentistry realize their financial support?

\section{PRINCIPAL FINDINGS}

The survey data offer a comparison of the development officer respondents' perceptions of the importance of various constituencies in providing supporting funds for their schools. Alumni scored a higher rating (mean 3.2) than nonalumni (mean 2.6), which is slightly higher than private foundations (mean 2.3) and business/industry (mean 2.2). Clubs/organizations received the lowest rating in importance (mean 2.0) as funding sources, perhaps reflecting the limited attention given non-alumni, private foundations, business/industry, and clubs/organizations by American schools of dentistry.

It is interesting to note that the degree of importance in providing supporting funds for schools of dentistry is relatively low for non-alumni, private foundations, business/industry, and clubs/organizations. These consitutencies were, for the most part, evaluated as 'generally ineffective' (value 2) by at least 40.0 percent or more of the responding development officers. Their relatively low degree of importance may indicate either a record of little success with these consitutencies or little attention given to them during the active solicitation process. 
Furthermore, development officers were asked to evaluate the importance of various funding sources by the amount of development time and/or money expended by the school in seeking financial support from these sources. The majority of the development officer respondents (twenty-two development officers or 88.0 percent) indicated that the prime focus of their consideration is the alumni. Consequently, the alumni category scored the highest rating with a mean 3.8 (value 4 being highest). In sum, alumni, annual fund, and major gift programs are rated first, second, and third, respectively. The alumni category received the highest rating (mean 3.8 ) while annual funds received a higher rating (mean 3.6) than major gift programs (mean 3.2), which is appreciably higher than non-alumni (mean 2.8), business and industry (mean 2.5), deferred (planned) gifts (mean 2.5), and capital projects (mean 2.5). Clubs and organizations are last in the rating of importance with a substantially lower rating of mean 2.0.

\section{RESEARCHQUESTION FIVE}

5. What are the most effective fund raising techniques used in American schools of dentistry?

a. What types of strategies attract the largest gifts?

b. How are these effective operations planned, organized, and managed?

c. What did the deans characterize as the successful elements?

d. What did the school development officers characterize as the successful elements?

\section{PRINCIPAL FINDINGS}

The majority of American schools of dentistry fund raising programs change in technique over the years, while remaining a year-round endeavor. Nevertheless, it is apparent that the annual fund is the core fund raising effort and although the alumni are the main driving force in this effort, they are not the only 
constituency involved. Additionally, most of the participating institutions have an annual fund drive, however, they vary in the manner in which solicitations take place. Ostensibly, there exists a common pattern of advancment activities among schools of dentistry and notwithstanding that differences exist, it can be seen that there are more common elements.

As one would anticipate, public relations plays a vital role in the success of a productive fund raising program. Both the dean respondents and the development officer respondents appear to be very conscious of the importance of the public's impression of their institution albeit that only 40.0 percent of the development officer respondents reported that the dean's office has been 'very active' (value 4) in identifying and publicizing substantive institutional activities that may be considered important by the community or prospective contributors and 36.0 percent reported that the dean's office has been 'generally active' (value 3 ). Furthermore, a majority of the dean respondents $(71.9$ percent) regard the public image of their institution as being 'very important' (value 4) and 18.8 percent consider it as being 'generally important' (value 3 ) despite the fact that only 21.9 percent of the dean respondents placed a 'heavy emphasis' (value 4 ) on school time or money that is expended in improving their school's public image while more than half ( 56.3 percent) placed a 'moderate emphasis' (value 3 ) in improving their institution's public image.

The guiding outlines of a model development program for American schools of dentistry appear to emerge from this study. Of the organizational methods used by the respondents, most prefer the one which has the school development officer reporting directly to and working closely with the dean and responsible for all fund raising and alumni functions, together with other functional areas. Moreover, the dean and the development officer perceive themselves as the principal participants in strategic planning, policy determination, and program evaluation of the school's advancement activities. 
As one would expect, alumni are rated the most important giving constituencies with non-alumni, private foundations, and business/industry a distant second, third, and fourth, respectively. Clubs and organizations received the lowest rating in importance as funding sources. Almost all of the participating schools of dentistry use special contributor organizations and have experienced increases in their membership in recent years. Alumni are the most effective members of these organizations in cultivating prospective contributors and in making the annual fund a productive fund raising event for schools of dentistry.

Personal visits are regarded by the respondents as the most effective fund raising technique. Additional techniques seen as successful in facilitating fund raising include, in order of effectiveness, phoning by alumni, personalized letters, suggested gift amounts, special gift program, designated gifts, and class reunion giving. Furthermore, scholarships are cited as the gift-use most attractive in positively influencing donors to contribute. Specific academic areas and capital projects are the only other gift-uses considered more than 'generally attractive'. Interestingly, responses also suggest that donors have little interest in providing funds for research.

Despite the fact that most deans did not become involved in the mechanics and specific techniques of fund raising for their institutions, all dean respondents developed and communicated a philosophy and a perspective of institutional direction. The greater number of the dean respondents perceive themselves as the leading member of the school's advancement activities and hence, are involved in the cultivation and solicitation of major donors. They believe the development of relationships are important and strive for effective and productive advancement activities. In sum, notwithstanding that most deans are not totally aware of specific mechanics the development officer employs, nonetheless, they are responsible for developing the overall goals, organization, and philosophies of their school's advancement activities. 
At length, the dean respondents characterized the alumni as the most important giving constituency and the annual fund as the principal funding source. They also regard personal visits as the most effective method of soliciting funds for their institutions.

The development officer respondents emphasized ideas, goals and directions of their school's advancement program while being most aware of the specific mechanics of fund raising. They communicated each institution's reputation and their own philosophy and style in identifying, cultivating, soliciting and acknowledging funding sources. The programs, methods and techniques seen as effective by the development officer respondents in facilitating fund raising include:

. The dean's involvement in and providing effective leadership for the school's advancement activities;

- The annual fund as the leading fund raising program:

The annual fund is the principal source of gift income;

. Strategic planning:

Anticipating the future and attempting to mold it;

- Exemplary organization of school development resources and planning an appropriate course of action:

Anticipating future problems and opportunities and designing strategies to cope with and take advantage of them;

- Identifying and cultivating potential funding sources with emphasis on the cultivation of major donors:

Development officers should be viewed as strategic managers searching for opportunities in the environment; 
- Personal contacts especially at higher giving levels:

The school must establish relationships or 'interface' with potential funding sources in the environment in order to survive;

- Social and solicitation events

The development officers are responsible for coordinating all fund raising activities, expecially the efforts of the dean in the solicitation of gift income;

. Phonathons:

Very effective, especially those conducted by alumni.

Finally, based upon the design of and responses to the dean and development officer survey instruments, the following comparative analysis of a common survey question is intended to provide the reader with an insight into the perceptions of the respondents regarding the dean's involvement in the school's advancement activities.

School of dentistry deans and development officers were asked to appraise the involvement of the dean in the school's advancement activities. The following Tables 4.51 through 4.55 describe how the respondents rated the five activities and the extent of the dean's involvement in those activities as well as providing a comparison of their perceptions. Respondents rated each activity on a four-point scale from "Very Involved" (4) to "Very Uninvolved" (1) and a t-test was used to compare the means of the ratings. 
TABLE 4.51

DEAN'S INVOLVEMENT IN ADVANCEMENT ACTIVITIES:

COMPARING PERCEPTIONS OF DEANS AND DEVELOPMENT OFFICERS

T-TEST FOR: SEEKING FINANCIAL SUPPORT

Groups

$\mathrm{N}$

Mean

SD

Deans

32

3.53

.67

Dev. Officers

25

3.20

1.41

$t=1.08$

$\mathrm{p} \leq=.288$

Seeing that $p \geq .05$, it was concluded that there was no significant difference between the means of the two groups comparing the dean's involvement in seeking financial support.

Table 4.52

DEAN'S INVOLVEMENT IN ADVANCEMENT ACTIVITIES:

COMPARING PERCEPTIONS OF DEANS AND DEVELOPMENT OFFICERS

T-TEST FOR: SOLICITING MAJOR DONOR

Groups

Deans

Dev. Officers

$$
t=2.96
$$

N

32

3.50

.76

25

2.76

1.05

Mean

SD

$\mathrm{p} \leq=.005$

Here we see that there is a significant difference in the respondents' perceptions of the dean's involvement in soliciting major donors since $p \leq .05$. 
Table 4.53

DEAN'S INVOLVEMENT IN ADVANCEMENT ACTIVITIES:

COMPARING PERCEPTIONS OF DEANS AND DEVELOPMENT OFFICERS

T-TEST FOR: SOLICITING POTENTIAL DONOR

\begin{tabular}{lccc} 
Groups & $\mathrm{N}$ & Mean & SD \\
\hline & & & \\
Deans & 32 & 3.47 & 1.24 \\
Dev. Officers & 25 & 3.00 & 1.56 \\
$\quad \mathrm{t}=1.23$ & $\mathrm{p} \leq=.225$ & &
\end{tabular}

There is no significant difference between the means of the ratings because $p \geq$ .05

Table 4.54

DEAN'S INVOLVEMENT IN ADVANCEMENT ACTIVITIES:

COMPARING PERCEPTIONS OF DEANS AND DEVELOPMENT OFFICERS

T-TEST FOR: EVALUATING FUND RAISING PROGRAMS

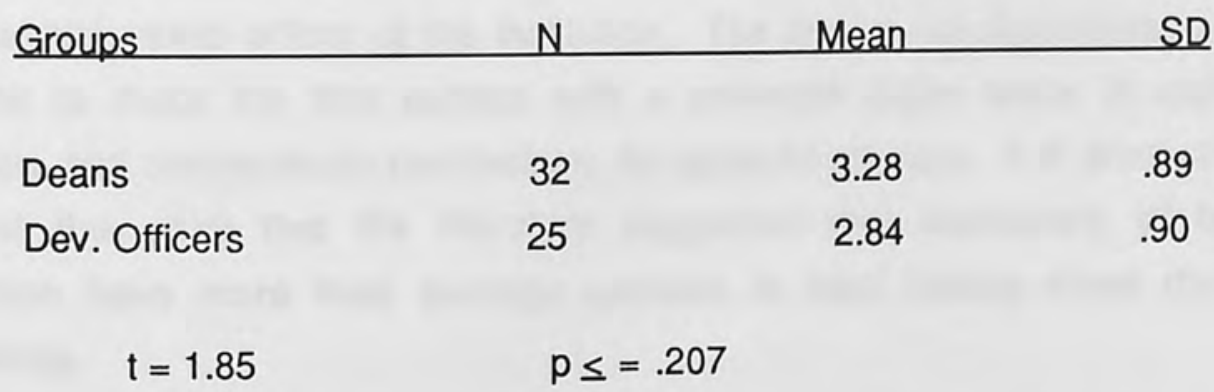

Inasmuch as $p \geq .05$, it can be inferred that there is no significant difference between the means of the respondent groups by their rating of the dean's involvement in evaluating fund raising programs. 
Table 4.55

DEAN'S INVOLVEMENT IN ADVANCEMENT ACTIVITIES:

COMPARING PERCEPTIONS OF DEANS AND DEVELOPMENT OFFICERS

T-TEST FOR: ESTABLISHING FUND RAISING POLICY

Groups

$N$

Mean

SD

Deans

Dev. Officers

25

2.44

1.16

$t=3.43$

$\mathrm{p} \leq=.001$

In view of the fact that $p \leq .05$, it can be said that there is a significant difference in the respondents' perceptions of the dean's involvement in establishing fund raising policy for the school's advancement activities.

Overall, the analysis indicates that the deans see themselves significantly more involved than do the development officers in the school's advancement activities. The results imply that the person responsible for the initial contact with a major donor or in establishing the school's fundraising policy ultimately will be the chief administrative officer of the institution. The deans see themselves as the persons to make the first contact with a potential major donor in order to articulate and communicate convincingly the school's mission. It is interesting to note at this point that the literature suggested that institutions of higher education have more than average success in fund raising when there is leadership.

Nonetheless, the development officers indicated in the follow-up interviews that, professionally, the development officer is in the best position to be successful, since he/she has the experience and expertise to make an appropriate approach. This finding seems to collaborate and reinforce the development officers' 
perceptions of the dean's involvement in the school advancement activities. Be that as it may, the follow-up interviews also revealed that on a "formal" basis, deans are not requested to represent their school in a fund raising capacity. They will, however, on an "informal" basis make positive inroads and are responsible for opening the door for the school's development officer.

In conclusion, an important aspect of the data analysis indicate that schools of dentistry are falling short of showing their value to the American business community. Too often, there is a lack of understanding of the direct benefits to American corporations of research and professional education in dentistry. American schools of dentistry should seek out innovative ways to show their value to the American public as well as to the corporate community to effect productive fund raising programs. Perhaps, schools of dentistry should focus their corporate fund raising activities on developing a case statement which communicates the philosophy and goals of the school as well as engaging in an evaluative program which measures the effectiveness of their advancement activities relative to achievement of stated goals.

Nevertheless, the institutions participating in this study give evidence that business-oriented management techniques are becoming increasingly operative at American schools of dentistry. Although, the educational enterprise is nonprofit and was formerly considered unaffected from intrusions of the market place, the present-day financial and demographic realities have required the utilization of appropriate business management tools and techniques. 


\section{CHAPTER FIVE}

\section{SUMMARY, CONCLUSIONS, AND RECOMMENDATIONS}

\section{INTRODUCTION}

American higher education has long sought to increase available resources through the solicitation of private gifts. American schools of dentistry have recently begun to utilize professional development officers to search out and use modern fund raising methods to uncover new funding sources as one very important means of strengthening the prospect for future survival of schools of dentistry. Effective fund raising programs rarely just happen. They are the result of careful planning and guidance, and their effectiveness is often dependent on the experiences and leadership of those in charge.

The problem identified for purposes of this study was how American schools of dentistry may organize and manage their fund raising programs to maximize voluntary financial support. The study attempted to address this problem by exploring:

The predominant organizational structure and management practices in the area of fund raising that have evolved at selected schools of dentistry;

The perceptions held by the deans and development officers in these same institution as to the effectiveness of certain practices relating to fund raising sources and constituencies, and methods and techniques used in their fund raising activities. These methods and techniques represent what may be considered the results of effective and successful plans; and 
The emerging pattern which might serve as a guide for development programs at other American institutions of higher education.

The research method selected for this exploratory study was a descriptive survey. According to Best (1970):

Descriptive research describes and interprets what is. It is concerned with conditions or relationships that exist; practices that prevail; beliefs; points of view; or attitudes that are held; processes that are going on; effects that are felt; or trends that are developing ....

In sum, this descriptive study was concerned with fact finding, describing, and analysis and interpretation of resulting data. However, because the study is descriptive research, the findings can not be used to establish cause-effect relationships.

\section{RESEARCHPROCEDURES}

The survey questionnaire method and structured personal interviews were used for the collection of data in this study. The questionnaire was the principal means of data collection and is designed to approach the problem by examining existing organizational structure and management of advancement activities at American schools of dentistry. The questionnaire also identified the perceptions of the deans and development officers and these perceptions served as the point of comparison for establishing the relative effectiveness of their advancement activities. Furthermore, to complement the data retrieved from the questionnaires, indepth personal interviews were conducted with the deans and development officers of the five California schools of dentistry. Hence, a combination of questionnaire and interview data serves as the basis for this study. 


\section{RESEARCH LIMITATIONS}

The purpose of survey research is to obtain information that describes existing phenomena by asking the individuals their perceptions, attitudes, or values. However, even though systematic methods were used to prepare, mail, and follow-up, the survey research method always has the possibility that different questions were interpreted in different ways without the researcher present to assure consistent delivery of instructions and questions.

An attempt was made to construct an investigation about which valid statements could be made regarding fund raising in American schools of dentistry as well as in other institutions of higher education. This investigation dealt with the total population of 55 schools of dentistry located in 34 states and in Puerto Rico. All institutions included in this investigation are accredited by their respective regional associations.

Forty-five institutions (82\%) in thirty states including Puerto Rico (88\%) participated in the survey and thirty-five deans (64\%) and thirty-five development officers $(64 \%)$ responded to the survey. Of those responses, thirty-two were usable for the dean group and twenty-five for the development officer group while forty-one institutions contributed to the analysis. Hence, conclusions drawn were tempered by these limitations in determining representativeness of the respondents.

\section{SUMMARY}

The deans and development officers cooperating in this study give evidence that their major development-related functions are consistent with trends toward greater specialization in fund raising. Historically, fund raising in American higher education was divided into the traditional categories of alumni funds and capital campaigns; development practitioneers looked to the basic constituency, the alumni, for both kinds of support. However, at the present time, gift income 
arises not only from different kinds of support, but from different kinds of constituencies. Alumni and capital funds have been complemented by special gifts, deferred giving, estate planning, government funds, and corporate/ foundation support.

In terms of organizational control of the school's fund-raising program, four basic organizational control patterns were identified (see Iable 3.1. p. 82 . Population of the Study). The four organizational patterns for fund raising are recognized in the fifty-five American schools of dentistry, with variations evidenced in individual institutions. The first organizational pattern includes those schools of dentistry that use a centralized organizational approach in which the school development officer has direct control over its fund-raising programs and reports directly to and works with the school dean. The second organizational pattern comprises those schools that have the development officer responsible for fund-raising programs reporting directly to the health sciences development office, while other schools have the development officer report directly to the university development office. The third organizational pattern encompasses those schools of dentistry that have dual organizational control over their fundraising programs where the school development officer is responsible to the school dean and to the health sciences development office; where the school development officer is responsible to the school dean and to the university development office; and where the school development officer is responsible to the health sciences development office and to the university development office. The fourth organizational arrangement is where the school's fund-raising efforts are controlled by a university foundation. Here the schools of dentistry report the existence of a legally separate and private foundation which is responsible for the school's fund-raising program and serves in a supportive function for the school.

The literature of American higher education fund raising generally concedes that there is no ideal organizational pattern for institutional advancement activities. However, it is the perception of the researcher, based on analysis of the 
organizational patterns of the individual institutions in this study, that a centralized organizational approach to the coordination of advancement activities, in which the school development office has direct control over its fund raising programs and reports directly to and works closely with the school dean, appears to work well for those institutions now having such an approach, and could be conducive to increased efficiency of the advancement effort in those not having it. The fact that approximately one-half of the development officer respondents to the survey reported that their schools have assumed a centralized advancement approach, with a separate coordinating development office, is indicative of these institutions' agreement with the researcher's perception.

Notwithstanding that most deans did not become involved in the mechanics and specific techniques of advancement activities, all dean respondents developed and communicated a philosophy and a perspective of institutional direction. The majority of the dean respondents perceive themselves as the major fund raising officer and become involved in the cultivation and solicitation of major donors. They believe the development of relationships is important and strive for effective and productive advancement activities.

The fact that the majority of development officer respondents give the alumni, annual fund and major gift programs a significantly higher rating in importance implies some success with these funding strategies and sources. The lower rating of importance placed on non-alumni, business and industry, private foundations, deferred (planned) gifts, and capital projects, and the lowest rating placed on clubs and organizations perhaps suggest more time and attention should be devoted to these potential funding sources. For all one knows, an underlying reason why so little success is obtained and/or attention given to schools of dentistry advancement activities by these potential funding sources may be the relative position of these institutions within the university community compared with other health science institutions (i.e., schools of medicine). In other words, who knows but that the major weakness of fund raising efforts in American 
schools of dentistry may be the perceived position and importance of dental health to total health care.

\section{CONCLUSIONS}

This inquiry led to conclusions related to the specific purpose of the study as stated in the first chapter and the conclusions are based on the findings of the investigation which are presented in chapter four. Specific conclusions reached in this study relative to the role of the dean and development officer as principal administrators in the school's advancement activities and to the implications for American schools of dentistry are set forth:

1. American schools of dentistry strive to gain the reputation of quality institutions. They utilize many indices to measure success. However, a most important index of success is the school's commitment to the growth and improvement of its advancement activities measured in terms of the allocation of physical and financial resources. Those schools of dentistry which can not or will not make such a commitment may place the continuance of their school at risk.

2. Strategic planning has become an adopted procedure in the administration of American schools of dentistry and fund raising has become a crucial element in the overall planning process. Although practices vary, the dean and development officer appear to have a sufficiently direct and important role in the establishment of fund raising policy, strategic planning, and program evaluation for their school's advancement activities. 
3. The involvement of other key personnel in the school's advancement activities is limited; faculty and staff are under-utilized as volunteer workers. Hence, special emphasis should be directed to expanding the involvement of these groups in soliciting donations.

4. The alumni constituency is recognized and utilized as traditional supporters of their alma mater. However, at the present time, gift income derives not only from different kinds of support, but from different kinds of constituencies such as special contributor organizations which include various levels to encourage specific amount donations. Hence, an ongoing investigation should be conducted which would identify the services and benefits desired by, and appropriate for, members of these organizations and other contributors.

5. A surprisingly large number of schools of dentistry have failed to develop a case statement which communicates the philosophy and goals of the institution. Succinctly, American schools of dentistry case statements should contain a clear expression of the philosophy and goals of the institution as well as a sensitivity to current market and economic trends as they affect attendance at and support of schools of dentistry. Additionally, the case statement should contain an awareness of the degree of credibility presently possessed by schools of dentistry in terms of fiscal management and social responsibility.

6. The fund raising efforts of schools of dentistry are inadequate in the corporate and foundation arena. A large number of respondents reported their business community fund raising efforts as unsuccessful. Foundation and corporate support appear to be more ambiguous in nature and not quite as capable of being influenced in the same manner as alumni support. Schools of dentistry should consider 
the employment of a fund raising consultant to assist in their corporate and foundation fund raising activities.

7. Gift income flows from different kinds of support and different kinds of constituencies. Among the various categories of gift income, schools of dentistry recognize the importance of and emphasis on the annual fund as a continuous and main and stable source of income. Sustained emphasis should be placed on the importance of the annual fund, but an enhanced emphasis on corporate, foundation and deferred (planned) giving may give rise to consequential results.

8. The guiding outlines of a model development program for American schools of dentistry appear to emerge from this exploratory study. However, no golden organizational structure, applicable to all schools of dentistry, will evolve from this investigation since each institution's structure depends, to a large extent, on individual characteristics, needs, and approaches.

\section{RECOMMENDATIONS}

This exploratory study examined the role of the dean and development officer as principal administrators of advancement activities and sought to identify the implications for American schools of dentistry. This study is among the first of its kind in the field of development for schools of dentistry. While some interesting and important information was gathered, more study of development practices and giving patterns to schools of dentistry is needed. Suggestions for further research are as follows:

1. Further research is needed to determine, on the basis of cost-benefit analysis, the amount of money expended on fund raising programs and the amount of money raised by fund raising programs. In other 
words, what is the optimum amount of dollar return for each additional dollar invested in fund raising efforts by schools of dentistry?

2. Further research is needed to determine what factors may promote or hinder philanthropic motivations among potential and actual constituencies, with special emphasis on the corporate and foundation funding sources. If more empirical data were available on what motivates potential donors, then fund raising for schools of dentistry would become more precise and effective.

3. Further research should be conducted to analyze the dean's office involvement and activity relative to fund raising in terms of solicitation calls made and gift dollars contributed to schools of dentistry.

4. Further research should be carried out to compare the advancement activities of development officers at private and public schools of dentistry. The similarities and differences of their operations could be analyzed and implications for the school's administration could be discerned.

5. Further research is needed to resolve how to organize and develop a comprehensive fund raising program for American schools of dentistry with special emphasis on annual, deferred (planned), capital and major giving.

Moreover, it is the researcher's perspective on advancement activities in American schools of dentistry that little information is being shared by the school development officers about specific fund raising programs. While the American Association of Dental Schools (AADS) has a large membership and offers a variety of informational services, there is little information concerning 
successful fund raising strategies among schools of dentistry. Further study is recommended to determine the most effective means for developing communications networks among American schools of dentistry development officers to further enhance their school's advancement activities.

Finally, in an atmosphere of declining enrollments, rising costs, and an increasing emphasis on quality education, the need for effective fund raising is important to American dental education. During the past decade, schools of dentistry, both public and private, faced difficult financial problems with no apparent end in sight. A growing number of institutions have been threatened by the unstable economy and shrinking applicant pools and are faltering under this threat. Private dental education seems to be especially vulnerable to financial difficulty and has been historically dependent upon philanthropic support to complement traditional revenues in an effort to remain financially viable. As a result of this changing environment, the identification and development of enhanced and more diversified fund raising strategies has emerged as one of the most significant and far-reaching needs presently confronting American dental education.

\section{POSTSCRIPT}

After an extensive review of the pertinent literature, some additional perspectives on fund raising in American higher education are in order. The turbulent environment in American higher education calls for new strategies, new kinds of leaders, and in many instances, amelioration of its institutional and administrative cultures. For instance, sustainable competitive strategies will have to be built not only around academic offerings and reputation, but also around consumer research, public relations, strategic planning and fund raising. To realize its potential, academe will have to tell its story, adapt to market needs and preferences, plan for the long-term view, and gain the financial and other support of alumni, friends, business and government. Today, academic leaders are selected on the basis of managerial, leadership and interpersonal skills, as 
well as political adeptness and academic credentials. To be an effective leader/manager, a president or dean should assume the roles of the chief strategic planner, the head public relations official, and the linchpin in fund raising. Even though few college or university officials can be first-rate simultaneously in academics, public relations, strategic planning, and fund raising, a basic knowledge is required in order for the chief academic officer to be conversant with the executives in charge of these various areas and thus to be successful in moving the institution upward and onward toward the 21 st century. 


\section{REFERENCES}




\section{REFERENCES}

Albers, H. (1974). Principles of Management: A Modern Approach (4th Ed.). New York, NY: John Wiley and Sons.

Appelbaum, R.L. (1974). The Process of Group Communication. Chicago, IL: Science Research.

Badin, I.J. (1974). "Some Moderator Influences on Relationships Between Consideration, Initiating Structure, and Organizational Criteria." Journal of Applied Psychology, 59: 380-382.

Baldridge, J.V., Curtis, D.V., Ecker, G., and Riley, G.L. (1978). Policy Making and Effective Leadership: A National Study of Academic Management San Francisco, CA: Jossey-Bass.

Bales, R. (1958). "Task Roles and Problem Groups." In E. Machoby, T. Newcomb, and E. Hartley (Eds.). Readings in Social Psychology. New York, NY: Holt, Rinehart and Winston.

Barrett, E. (1974). "The Art and Science of Being a Dean." NVRS Outlook. 22: 748750 , December.

Bass, B.M. (1960). Leadership. Psychology, and Organizational Behavior. New York, NY: Harper and Row.

Bennis, W. and Nanus, B. (1985). Leaders: The Strategies for Taking Charge. New York, NY: Harper and Row.

Best, J. W. (1970). Research in Education. Englewood Cliff, NJ: Prentice Hall. 
Birnbaum, R. (1989). "The Implicit Leadership Theories of College and University Presidents." The Review of Higher Education. 12, No. 2 (Winter 1989): 125-136.

Boorstin, D. J. (1973). The Americans: The Democratic Experience, New York, NY: Random House.

Boulding, K. (1975). "The Management of Decline." Change, 64, 8-9.

Bowen, H.R. (1969). Margin for Excellence and Opportunity. Washington, DC: National Association of State Universities and Land-Grant Colleges.

Bowen, H.R. (1980). The Costs of Higher Education. San Francisco, CA: Jossey-Bass.

Bowen, H.R. (1983). "The Art of Retrenchment." Academe. January - February.

Bowen, H.R. and Schuster, J. H. (1986). American Professors: A National Resource Imperiled. New York, NY: Oxford University Press.

Broce, T. R. (1979). Fund Raising: The Guide to Raising Money From Private Sources, Norman, OK: University of Oklahoma Press.

Buchen, T. (1974). "The Swinging Monk, or the Dean of the Future." Intellect 102: 497-500, May.

Burns,, J.M. (1978). Leadership. New York, NY: Harper and Row.

Chandler, J. and Cockle, P. (1982). Techniques of Scenario Planning. New York, NY: McGraw-Hill Book Co.

Charters, W.W. (1964). Teacher Perceptions of Administrator Behavior. St. Louis, MO: Washington University. 
Chater, S. (1983). "Women Administrators in Higher Education." In M. Conway and O. Andreuskin Administrative Theory and Practice Norwalk, CT: Appleton-Century-Crofts.

Clark, B.R. (1987). The Academic Life: Small Worlds. Different Worlds. The Carnegie Foundation for the Advancement of Teaching. Princeton, NJ: Princeton University Press.

Cornesky, R. A. and Bolte, J.R. (1986). Practical Long-Range Planning and Resources Allocation Procedures for Colleges and Universities. Lubbock, TX: Texas Tech Press.

Corson, J. (1975). The Governance of Colleges and Universities. New York, NY: McGraw-Hill Book Co.

Council for Financial Aid to Education (CFAE). Voluntary Support of Education. 198586, New York, NY: June 1987.

Culbert, C.J., and Conrad, R. (1970). How to Communicate And Succeed. New York, NY: Vantage.

Dawson, J. E. (1970). Consideration and ICS: Instructor Leadership Influencing Student Performance. East Lansing, Ml: Michigan State University, Human Learning Research Institute.

Dawson, J. E., Meese, L.A., and Phillips, J. L. (1972). "Effect of Instructor-Leader Behavior in Student Performance." Journal of Applied Psychology. 56: 369-376.

Dibden, A.J. (1968). The Academic Deanship in American Colleges and Universities. Illinois: Southern Illinois University Press.

Dill, W. (1980). "The Deanship: An Unstable Craft." In D. McCarty and D. Griffiths (Eds.): The Dilemma of the Deanship. Danville, IL: Interstate Printers and Publishers, Inc. 
Dressler, G. (1980). Organizational Theory: Integrating Structure and Behavior. Englewood Cliffs, NJ: Prentice-Hall, Inc.

Drucker, P. (1975). Management: Tasks. Responsibilities. Practices. New York, NY: Harper and Row Publishers, Inc.

Drucker, P. F. (1979). "Good Growth and Bad Growth." The Wall Street Journal. April 10: 26 .

Ebenstein, M. (1981). "Strategic Planning for Information Resources Management." Management Review. 70 (June 1981), 21-26.

Fact Book on Higher Education. (1968). Washington, DC: American Council on Education.

Federal Support to Universities and Colleges, FY 1963-1966 (1967), Washington, DC: National Science Foundation, 67-17.

Federal Support to Universities and Colleges. FY 1967, (1969). Washington, DC: National Science Foundation, 69-7.

Fiedler, F., Chemers, M., and Mahar, L. (1977). Improving Leadership Effectiveness. New York, NY: John Wiley and Sons, Inc.

Fiedler, F. (1971). "Validation and Extension of the Contingency Model of Leadership Effectiveness: A Review of Empirical Findings." Psychological Bulletin. 76: 128-148.

Fleishman, E. (1953). "Leadership Climate, Human Relations Training, and Supervisory Behavior." Personnel Psychology, 6: 205-255, 
Flocco, E.C. (1969). "An Examination of the Leader Behavior of School Business Administrators." (Unpublished Doctoral Dissertation). Ann Arbor, MI.: University Microfilms International.

Frantzreb, A. C. (1979). Setting Fund Raising Priorities. Washington, DC: Council for the Advancement of Small Colleges.

French, M. (1985). Beyond Power. New York, NY: Ballantyne Books.

Good, C. V. and Scates, D.E. (1954). Methods of Research: Educational. Psychological. Sociological. New York, NY: Appleton-Century-Crofts, Inc.

Green, J. and Monical, D. (1985). "Resource Allocation in a Decentralized Environment." In D.J. Berg and G. Skogley (Eds.), Making the Budget Process Work. New Dimensions for Higher Education, No. 52. San Francisco, CA: Jossey-Bass, Inc.

Greenfield, T.B., and Andrews, J.H.M. (1961). "Teacher Leader Behavior." Alberta Journal of Education Research. 7:92-102.

Griffith, D.E., and McCarty, D.J. (Eds.) (1980). The Dilemma of the Deanship. Danville, IL: Interstate Printers and Publishers, Inc.

Guardo, C.G. (1982). "Defining the Mission of a University." Case Currents, 7: 24-27.

Halpin, A.W., and Weiner, B.J (1973). "A Factorial Study of the Leader Behavior Descriptions." In R.M. Stogdill and A.E. Coons (Eds.) Leader Behavior: Its Description and Measurement. Columbus, $\mathrm{OH}$ : Ohio State University.

Halpin, A. (1958). Administrative Theory in Education. Midwest Administrative Center, University of Chicago. 
Halpin, A. W. (1957). Manual for the Leader Behavior Description Questionnaire. Columbus, $\mathrm{OH}$ : Ohio State University.

Halpin, A. W. (1966). Theory and Research in Administration. New York, NY: MacMillan.

Hemphill, J.K. (1950). Leader Behavior Description. Columbus, OH: Ohio State University, Personnel Research Board.

Hemphill, J. K. (1955). "Leadership Behavior Associated with the Administrative Reputations of College Departments." Journal of Educational Psychology. 46:385-401.

Hemphill, J. K. and Coons, A. E. (1957). "Development of the Leader Behavior Description Questionnaire." In R. M. Stogdill and A. E. Coons (Eds.) Leader Behavior: Its Description and Measurement. Columbus, $\mathrm{OH}$ : Ohio State University.

Hersey, P., and Blanchard, K.H. (1982). Management of Organizational Behavior: Utilizing Human Resources. Englewood Cliffs, NJ: Prentice-Hall.

"Higher Education is a U. S. Industry." Higher Education and National Affairs, July 28, 1986, p. 3.

Hipps, G. M. (1982). "Summary and Conclusions." In G. Melvin Hipps (Ed.), Effective Planned Change Strategies. New Directions for Institutional Research Series. San Francisco, CA: Jossey-Bass, Inc.

Hodges, R., and Hodges, L. (1975). "The Role of Academic Dean." Educ. Rec. 56 (1): 39-41, Winter.

Hofstadter, R. and Metzger, W.P. (1955). Development of Academic Freedom in the United States. New York, NY: Columbia University Press. 
Hood, P.D. (1963). Leadership Climate for Trainee Leaders: The Army AIT Platoon. Washington, DC: Human Resources Research Office.

Howe, F. (1983). "Trustees and the Fund Raising Role: Facing the Hard Truth." AGB Reports 25 (September-October 1983), 19-23.

Hoy, W., and Miskel, C. (1982). Educational Administration: Theory, Research and Practice. New York, NY: Random House.

Hunt, J. (1967). "Fielder's Leadership Contingency Model: An Empirical Test in Three Organizations." Organizational Behavior and Human Performance. 2: 290-308.

Hunter, F. (1959). Iop Leadership. U.S.A. Chapel Hill, NC: University of North Carolina Press.

Jacobsen, W. (1972). Power and Interpersonal Relations. Belmont, CA: Wadsworth Publishing, Inc.

Keller, G. (1983). Academic Strategy. Baltimore, MD: The Johns Hopkins University Press.

Keller, B.T., and Andrews, J.H.M. (1963). "Leader Behavior of Principals, Staff Morale, and Productivity." Alberta Journal of Education Research. 9: 179-191.

Kerr, S., Schriesheim, C.A., Murphy, C.J., and Stogdill, R.M. (1974). "Toward a Contingency Theory of Leadership Based Upon The Consideration and Initiating Structure Literature." Organizational Behavior and Human Performance. 12: 62-82.

Knezevich, S. (1975). Administration of Public Education. New York, NY: Harper and Row. 
Kotler, P. (1982). Marketing for Non-Profit Organizations. Englewood Cliffs, NJ: Prentice-Hall, Inc.

Kunec, J. L. (1982). "Market Your Mission By Stating Your Case." Fund Raising Management. 3: 26-31.

Kuntz, D., and Hoy, W. (1974). "Leadership Styles of Principals and the Professional Zone of Acceptance of Teachers." Educational Administration Quarterly. 12: (3): 4964.

Langford, T. (1981). Managed and Being Manager. Englewood Cliffs, NJ: PrenticeHall, Inc.

Lee, C.G. (1969). The Struggle for Federal Aid. New York, NY: Columbia University Bureau of Publications.

Leslie, J.W. (1971). Seeking the Competitive Dollar: College Management in the Seventies. Washington, DC. American College Public Relations Association.

Lindemuth, M.H. (1969). "An Analysis of the Leader Behavior of Academic Deans as Related to the Campus Climate in Selected Colleges." (Unpublished Doctoral Dissertation). Ann Arbor, Ml: University Microfilms International.

Linnell, J. (1974). "The Academic Deans Enabler." Lib. Educ. 60: 368-376, October.

Luckie, W. R. (1963). "Leader Behavior of Director of Instruction." (Unpublished Doctoral Dissertation). Ann Arbor, Ml: University Microfilms International.

March, J. G. (1982). "Emerging Developments in the Study of Organizations." The Review of Higher Education. 6: 1-18. 
Marts, A. C. (1953). Philanthropy's Role in Civilization: Its Contribution to Human Ereedom. New York, NY: Harper and Brothers.

Mayhew, L. B. (1977). Legacy of the Seventies. San Francisco, CA: Jossey-Bass Publications.

McCorkel, C.O., and Archibald, S. D. (1982). Management and Leadership in Hiaher Education. San Francisco, CA: Jossey-Bass.

McGannon, J. B. (1973). "Academic Dean: Dimensions of Leadership." Lib. Educ. 59: 277-291, October.

McGregor, D. (1976). "An Analysis of Leadership." In W. Lassey and R. Fernandez (Eds.). Leadership and Social Change. La Jolla, CA: University Associates; Reprinted from McGregor, D., The Human Side of Enterprise. New York, NY: McGraw-Hill, 1960.

McMahon, C.P. (1949). "College Drives - Five Hundred Years Old." School and Society. $70,423$.

Miles, R. E. (1975). Theories of Management: Implications for Organizational Behavior and Development. New York, NY: McGraw-Hill.

Millett, J. D. (1984). Conflict in Higher Education. San Francisco, CA: Jossey-Bass, Inc.

Morrison, J. and Cope, R. (1985). "Future Research Techniques in Strategic Planning: A Simulation." Planning for Higher Education. 13 (2), 5-9.

Muller, H. (1977). Handbook for Institutional Advancement. Rowland, W.A. (Ed.). San Francisco, CA: Jossey-Bass. 
Myran, G. A. (Ed.), (1983). Strategic Management in the Community College. New Directions for Community Colleges. No. 44, San Francisco, CA: Jossey-Bass, Inc.

Nealy, B., and Shiflett, K. (1969). "Validation and Extension of Leadership Effectiveness: A Review of Empirical Findings." In F. Fielder (Ed.), Psychological Bulletin. 76: 137.

Pray, F. C. (Ed.), (1981). Handbook for Educational Fund Raising. San Francisco, CA: Jossey-Bass.

Rowe, A., Mason, R., and Dickel, K. (1985). Strategic Management and Business Policy. Reading, MA: Addison-Wesley.

Rudolph, F. A. (1962). The American College and University: A History. New York, NY: Knopf.

Rowland, A. W., (Ed.), (1978). Handbook of Institutional Advancement. San Francisco, CA: Jossey-Bass.

Schriesheim, C.A., House, R.J. and Kerr, S. (1976). "Leader Initiating Structure: A Reconciliation of Discrepant Research Results and Some Empirical Tests." Organizational Behavior and Human Performance. 15:297-321.

Scott, W. R. (1974). "Organizational Theory: A Reassessment." Academy of Management Journal. 17, 242-54.

Smith, H. W. (1979). "Voluntary Support: The End Product of Fund Raising." In W. Heeman (ed.), Analyzing The Cost Effectiveness of Fund Raising, New Directions for Institutional Advancement. No. 3. San Francisco, CA: Jossey-Bass, Inc.

Socolow, D. J. (1978). "How Administrators Get Their Jobs." Change, 10 (May): $42-$ $43,54$. 
Somboon, O. (1984). "The Ideal Behavior of Nursing Deans" (Unpublished Doctoral Dissertation). Ann Arbor, MI: University Microfilms International.

Spotts, J. V. (1974). "The Problem of Leadership: A Look at Some Recent Findings of Behavioral Science Research." In J. A. Sarthory (Ed.), Educational Leadership. Renewal and Planning. New York, NY: MSS Information.

Sprunger, B. E., and Berquist, W. (1978). Handbook for College Administration. Washington, DC: Council for the Advancement of Small Colleges.

Stogdill, R. (1963). Manual for the Leader. Behavior Description Questionnaire Form XII. Columbus, OH: Bureau of Business Research, Ohio State University.

Stogdill, R. M. (1974). Handbook of Leadership: A Survey of Theory and Research. New York, NY: Free Press.

Tiedt, S. W. (1966). The Role of the Federal Government in Education. New York, NY: Oxford University Press.

Trow, M. (1988). "American Higher Education: Past, Present, and Future." Educational Researcher. April: 13-23.

Tucker, A. (1984). Chairing the Academic Department. Leadership Among Peers. New York, NY: American Council on Education, MacMillan.

Turner, J. H. (1978). The Structure of Sociological Theory. Homewood, IL: The Dorsey Press.

Vroom, V. H. (1983). "Leaders and Leadership in Academe." The Review of Higher Education. 6 (Summer 1983): 367-386. 
Whetten, D. A., and Cameron, K. S. (1985). "Administrative Effectiveness in Higher Education." Rev. Higher Educ. 9: 35-49.

Also See:

Whetten, D. A. (1984). "Effective Administration: Management on the College Campus." Change. 16 (8): 35-43.

Webster's New Collegiate Dictionary. Springfield, MA: G and C Merriam Company, 1981: 1141.

Whitehead, J. (1975). The Separation of College and State: Columbia. Dartmouth. Harvard. and Yale. 1776-1876. New Haven, CT: Yale University Press.

Williamson, J. P. (1975). Funds for the Future. New York, NY: McGraw-Hill.

Wolk, R. A. (1968). Alternative Methods of Federal Funding for Higher Education. Berkeley, CA: Carnegie Commission on Higher Education.

Yukl, G. A. (1981). Leadership in Organizations. Englewood Cliffs, NJ: Prentice-Hall.

Yukl, G. A. (1970). "Leader LPC Scores: Attitude Dimensions and Behavioral Correlates." The Journal of Social Psychology. 80: 207-212.

Zaleznik, A. (1977). "Managers and Leaders: Are They Different?" Harvard Business Review. May-June: 67-78. 


\section{APPENDICES}




\section{APPENDIX}

A

226 
April 16, 1991

Jay A. Gershen, D.D.S., Ph.D.

President

American Association of Dental Schools

c/o UCLA School of Dentistry

10833 Le Conte Avenue

Los Angeles, CA 90024-1668

Dear Jay:

This letter is to request your support and the support of the American Association of Dental Schools for a survey of fund raising programs at American schools of dentistry. This study will complete my requirements for the doctor of philosophy degree in Administration and Higher Education at The Claremont Graduate School.

The purpose of the survey is to establish a set of criteria for a model development program by an in-depth analysis of the organization, management, methods, and effectiveness of fund raising at American schools of dentistry.

I believe that this study will make a significant contribution to American schools of dentistry; hence, in cooperation with the A.A.D.S., I plan to disseminate the results of the study through the Association. I also believe that your support and that of the A.A.D.S. will make this contribution a reality.

If you have any questions regarding this matter, I would be most happy to meet with you at your convenience.

Thank you for your assistance and for taking time from your very full schedule to consider my request. I trust your work continues well.

Please find enclosed the survey instrument, cover letter, and abstract of the study. Time is of the essence, and I truly appreciate your kind regard in this endeavor.

Sincerely,

FRANK C. FLORES, JR., D.D.S., M.S. 
April 16, 1991

Jay A. Gershen, D.D.S., Ph.D.

President

American Association of Dental Schools

c/o UCLA School of Dentistry

10833 Le Conte Avenue

Los Angeles, CA 90024-1668

Dear Jay:

To substantiate my background in scholarly research of fund raising in higher education, I would like to share a project with you that I developed for the Council For International Exchange of Scholars. The project, Academic Strategic Planning in Advancement Activities at Institutes of Higher Education which I later translated into Spanish, has the support of Professor Jack H. Schuster of the Claremont Graduate School and Senior Jose Marie Anton, Attache for Education of the Spanish consulate. Also, please find enclosed an updated curriculum vitae.

Looking forward to hearing from you soon, regarding my request for your support and that of the American Association of Dental Schools of my survey of fund raising programs at American schools of dentistry.

Regards,

Frank C. Flores, Jr., D.D.S., M.S. 


\section{APPENDIX}

B 
April 16, 1991

John W. Crowe

Assistant Vice President

University Development

University Of Southern California

Administration 258, University Park

Los Angeles, CA 90089-0015

Dear John:

Thank you for agreeing to review the enclosed questionnaire that I will be using in my dissertation for the Ph.D. in Higher Education at The Claremont Graduate School. Your assistance is requested in rating the level of clarity/ambiguity of each of the questions, as well as the instructions to the respondents. Your suggestions as to terminology, question procedures, etc. will also be appreciated.

You are one of four senior development officers in higher education that are being asked to examine and critically evaluate the questionnaire.

It is essential to the study that experienced professional development officers review this instrument and comment on its clarity. Your experience and abilities in the area of development will certainly contribute to the quality of the instrument and the findings of my investigation.

Thank you again for your cooperation and for taking time from your very full schedule to participate in this vital review. I look forward to meeting with you when I pick up your evaluation. Also, if you would like a copy of the summary of my findings, please let me know.

Please complete your review by April 26, 1991. Time is of the essence, and I truly appreciate your assistance.

Sincerely,

Frank C. Flores, Jr. 


\section{The Claremont Graduate School}

April 16, 1991

Anita Comptois Reed

Director of Development

Pomona College

333 N. College Way

Claremont, CA 91711

\section{Dear Anita:}

Thank you for agreeing to review the enclosed questionnaire that I will be using in my dissertation for the Ph.D. in Higher Education at The Claremont Graduate School. Your assistance is requested in rating the level of clarity/ambiguity of each of the questions, as well as the instructions to the respondents. Your suggestions as to terminology, question procedures, etc. will also be appreciated.

You are one of four senior development officers in higher education that are being asked to examine and critically evaluate the questionnaire.

It is essential to the study that experienced professional development officers review this instrument and comment on its clarity. Your experience and abilities in the area of development will certainly contribute to the quality of the instrument and the findings of my investigation.

Thank you again for your cooperation and for taking time from your very full schedule to participate in this vital review. I look forward to meeting with you when I pick up your evaluation. Also, if you would like a copy of the summary of my findings, please let me know.

Please complete your review by April 26, 1991. Time is of the essence, and I truly appreciate your assistance.

Sincerely,

Frank C. Flores, Jr. 
April 16, 1991

Laurie A. Macaulay

Director of Development

Claremont University Center and Graduate School

Harper Hall 112

150 E. Tenth Street Claremont, CA 91711-6160

Dear Ms. Macaulay:

Thank you for agreeing to review the enclosed questionnaire that I will be using in my dissertation for the Ph.D. in Higher Education at The Claremont Graduate School. Your assistance is requested in rating the level of clarity/ambiguity of each of the questions, as well as the instructions to the respondents. Your suggestions as to terminology, question procedures, etc. will also be appreciated.

You are one of four senior development officers in higher education that are being asked to examine and critically evaluate the questionnaire.

It is essential to the study that experienced professional development officers review this instrument and comment on its clarity. Your experience and abilities in the area of development will certainly contribute to the quality of the instrument and the findings of my investigation.

Thank you again for your cooperation and for taking time from your very full schedule to participate in this vital review. I look forward to meeting with you when I pick up your evaluation. Also, if you would like a copy of the summary of my findings, please let me know.

Please complete your review by April 26, 1991 . Time is of the essence, and I truly appreciate your assistance.

Sincerely,

Frank C. Flores, Jr. 
APPENDIX

C 


\section{AMERICAN SCHOOLS OF DENTISTRY ADVANCEMENT ACTIVITIES QUESTIONNAIRE \\ Instructions and Form for Evaluating Questionnaire}

The attached questionnaire will be used to gather information on development programs from deans and senior development officers. Hence, clarity is of the essence. Your response will serve as a basis for final revision of this instrument.

Please rate the clarity/ambiguity level of the instructions and each question using the following scale:
1: CLEAR
2: UNDECIDED
3: AMBIGUOUS

On a separate sheet of paper, please comment on any item you consider to be ambiguous and indicate said item.

Question

\begin{tabular}{|c|c|c|c|c|c|}
\hline 1 & 14 & 27 & 40 & 53 & 66 \\
\hline 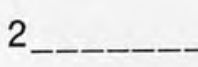 & 15 & 28 & 41 & 54 & 67 \\
\hline 3 & 16 & 29 & 42 & 55 & 68 \\
\hline $4_{---}$ & 17 & 30 & 43 & 56 & 69 \\
\hline 5 & 18 & 31 & 44 & 57 & 70 \\
\hline 6 & 19 & 32 & 45 & 58 & 71 \\
\hline 7 & 20 & 33 & 46 & 59 & 72 \\
\hline 8 & 21 & 34 & 47 & 60 & 73 \\
\hline 9 & 22 & 35 & 48 & 61 & \\
\hline 10 & 23 & 36 & 49 & 62 & \\
\hline 11 & 24 & 37 & 50 & 63 & \\
\hline 12 & 25 & 38 & 51 & 64 & \\
\hline 13 & 26 & 39 & 52 & 65 & \\
\hline
\end{tabular}

EVALUATOR POSITION INSTITUTION DATE

\section{EVALUATION}




\section{APPENDIX}

D

235 


\section{The Claremont Graduate School}

IEW FACULTY RESEARCH PROJECT

August 1, 1991

Dean John C. Green

School of Dentistry

University of California, San Francisco

Third and Parnassus Avenue

San Francisco, CA 94143

\section{Dear Dean Green:}

Thank you for participating in this research project. In cooperation with the American Association of Dental Schools, I am conducting a survey of advancement activities among American schools of dentistry and your assistance will contribute significantly to the quality of the findings. This study will complete my requirements for the Doctor of Philosophy degree in Administration and Higher Education at The Claremont Graduate School.

The purpose of the survey is to establish a set of criteria for a model development program by an indepth analysis of the organization, management, methods, and effectiveness of fund raising at American schools of dentistry.

I believe that this study will make a significant contribution to American schools of dentistry; hence, in cooperation with the A.A.D.S., I plan to disseminate the results of the study through the association. I also believe that your participation and that of your school will make this contribution a reality.

Please read the enclosed instructions, complete your review/evaluation, and return the completed questionnaire in the self-addressed, stamped envelope by August 23, 1991 . Time is of the essence, and I truly appreciate your efforts.

All responses will be kept confidential and the name of your institution will remain anonymous. Upon the completion of the study, all questionnaires will be destroyed. If you desire a summary of the findings after the completion of the study, please indicate so on the completed questionnaire.

Thank you for investing your valuable time in this much needed survey and mutually beneficial endeavor.

Sincerely,

Frank C. Flores, D.D.S., M.S.

Director, Project on Advancement Activities in American Schools of Dentistry 
August 1, 1991

Suzanne Ryer

Director of Development

College of Dentistry

New York University

345 East 24th Street

New York, NY 10010-4099

Dear Ms. Ryer:

Thank you for participating in this research project. In cooperation with the American Association of Dental Schools, I am conducting a survey of advancement activities among American schools of dentistry and your assistance will contribute significantly to the quality of the findings. This study will complete my requirements for the Doctor of Philosophy degree in Administration and Higher Education at The Claremont Graduate School.

The purpose of the survey is to establish a set of criteria for a model development program by an indepth analysis of the organization, management, methods, and effectiveness of fund raising at American schools of dentistry.

I believe that this study will make a significant contribution to American schools of dentistry; hence, in cooperation with the A.A.D.S., I plan to disseminate the results of the study through the association. I also believe that your participation and that of your school will make this contribution a reality.

Please read the enclosed instructions, complete your review/evaluation, and return the completed questionnaire in the self-addressed, stamped envelope by August 23, 1991 . Time is of the essence, and I truly appreciate your efforts.

All responses will be kept confidential and the name of your institution will remain anonymous. Upon the completion of the study, all questionnaires will be destroyed. If you desire a summary of the findings after the completion of the study, please indicate so on the completed questionnaire.

Thank you for investing your valuable time in this much needed survey and mutually beneficial endeavor.

Sincerely,

Frank C. Flores, D.D.S., M.S.

Director, Project on Advancement Activities in American Schools of Dentistry 


\section{The Claremont Graduate School}

September 10, 1991

\section{Dear}

Approximately one month ago, a survey packet was sent to you requesting your participation in a research project on advancement activities in American schools of dentistry. Unfortunately, as of this date, we have not received a completed questionnaire from you.

We are writing to you again because of the significance each questionnaire has to the usefulness of this study. In order for the results of this survey to be truly representative of all American schools of dentistry, it is essential that each institution return the completed questionnaire.

I am sure that you are burdened by many requests for information concerning your school's activities. However, I believe an analysis of factors which influence an educational institution's ability to raise financial support will be beneficial for your school as well as to other American schools of dentistry.

In the event that your questionnaire has been misplaced, please call (714) 621-8075 and a replacement will be sent to you without delay.

Thank you. Your cooperation is greatly appreciated.

Sincerely,

Frank C. Flores, Jr., D.D.S. , M.S.

Director, Project on Advancement Activities in American Schools of Dentistry 


\section{APPENDIX}

E 


\section{U N I V E R S I T Y O F T H E PAC I F I C}

School of Dentistry

Arthur A. Dugoni, D.D.S., M.S.D., Dean

August 1, 1991

Dear Colleague:

Institutional advancement is essential to the future of dental education. It can be the difference between success or failure for institutions committed to excellence in community service, education and research.

The enclosed survey, prepared by Dr. Frank Flores of the University of Southern California, will be an essential vehicle for assessing the developmental activities of American dental schools.

I would urge you to complete the enclosed survey. It is my understanding that the information compiled by Dr. Flores will be forwarded to the American Association of Dental Schools for distribution to the deans.

Sincerely,

Arthur A. Dugoni, D.D.S., M.S.D.

Dean and Professor of Orthodontics

$\mathrm{AAD} / \mathrm{ao}$ 


\section{Medical College of Virginia \\ Virginia Commonwealth University}

August 1, 1991

Tom Dunworth

Director of Development

School of Dentistry

University of the Pacific

2115 Webster Street

San Francisco, CA 94115

Dear Mr. Dunworth:

The enclosed survey prepared by Dr. Frank Flores of the University of Southern California offers us a useful tool for accessing our development operations. After reviewing the survey and discussing it with Dr. Preston Littleton, Jr. and several of you, I have offered my endorsement of this project in my official capacity as Chairman of the AADS section on Communications, Development, and Public Affairs. I hope you will take the time to complete this thorough document and encourage your dean to also complete such portions of the survey as you deem appropriate.

The information compiled by Dr. Flores will be used to complete his doctoral requirements and will be forward to us for our review. It is my hope that this information will be available to us in time for the ADA Meeting in seattle. (If we are able to organize a meeting during this time, if not then we will discuss this material in the spring during our section meeting in Boston). If you are not a member of the AADS, please complete the survey and the results will be mailed to you.

In my opinion, as development professional, surveys like this enhance our professional status while providing us with valuable information. Please call me at (804) 225-4695 if you have any questions concerning this survey and again thanks for all your support.

Sincerely,

Thomas C. Burke, Jr.

AADS Chair, section on Communications, Development, and Public Affairs. 


\section{APPENDIX}

\section{F}

242 


\section{AMERICAN SCHOOLS OF DENTISTRY \\ ADVANCEMENT ACTIVITIES QUESTIONNAIRE FOR SCHOOLDEANS}

Thank you for participating in this research project. In cooperation with the American Association of Dental Schools, I am conducting a survey of advancement activities among American schools of dentistry. It is my intention to identify successful fund raising methods and techniques, synthesize, and disseminate this information through the association. All responses will be kept confidential and the name of your institution will remain anonymous.

Please complete the following questionnaire and return by August 23, 1991 in the envelope provided. Do not leave any item blank. If a question does not pertain to your institution, please signify by marking it NA.

If you wish to elaborate any answer, please do not hesitate to do so on the back of the page and mark the particular question accordingly. If you desire a summary of the findings after the completion of the study, please indicate:

Yes__ No

Thank you for your cooperation.

Questionnaire Completed By:

Name:

Title:

Institution:

Location: Date

\section{ADVANCEMENT ACTIVITIES QUESTIONNAIRE}

This questionnaire is composed of three sections:

. Institutional Information

- Organizational structure and management practices; and

- Fund raising methods and techniques.

Most items can be completed with check marks. 
INSTITUTIONAL INFORMATION

Name

Location

Enrollment (Academic 1989-90):

Pre-Doctoral

Post-Doctoral

Other

Faculty:

Full-Time

Part-Time

Volunteers

Other

Budget (FY 1989-90):

Revenues (FY 1989-90):

Tuition/Fees

Patient Care

Gifts

Endowments

Grants/Contracts

Other 
INSTITUTIONAL INFORMATION

Name

Location

Enrollment (Academic 1990-91):

Pre-Doctoral

Post-Doctoral

Other

Faculty:

Full-Time

Part-Time

Volunteers

Other

Budget (FY 1990-91):

Revenues (FY 1990-91):

Tuition/Fees

Patient Care

Gifts

Endowments

Grants/Contracts

Other 


\section{ORGANIZATIONALSTRUCTURE AND MANAGEMENT PRACTICES}

1. How involved in the school's fund raising program is each of the following persons in establishing the overall administration policy and in setting institutional priorities?

$\begin{array}{llll}\text { Very } & \text { Generally } & \text { Generally } & \text { Very } \\ \text { Uninvolved } & \text { Uninvolved } & \text { Involved } & \text { Involved }\end{array}$

\section{Dean}

School Development

Officer

Associate/Assistant

Deans

Dept. Chairs/

Faculty

Alumni Support

Groups

University Adm./

Development

Other (Please Specify)

2. Does the school have a strategic planning process for its overall governance?

Yes

No

3. Does the school utilize strategic planning as a management tool for advancement activities?

Yes No

4. How involved is the school development officer in overall school planning apart from fund raising?

Very

Uninvolved
Generally

Uninvolved
Generally

Involved
Very

Involved 
5. How involved is the school development officer in the following advancement activities?

$\begin{array}{llll}\text { Very } & \text { Generally } & \text { Generally } & \text { Very } \\ \text { Uninvolved } & \text { Uninvolved } & \text { Involved } & \text { Involved }\end{array}$

Providing Effective

Leadership

Seeking Financial

Support

Recruiting

Volunteers for

Solicitation

Identifying and

Involving Volunteer

Leadership

Soliciting Potential

Major Donor

Soliciting Potential

Donor

Evaluating Fund

Raising Programs

Establishing Fund

Raising Policy

6. How involved are you as dean in the following advancement activities?

Seeking Financial

Uninvolved Uninvolved Involved

Very

Involved

Support

Recruiting

Volunteers for

Solicitation

Identifying and

Involving Volunteer

Leadership

Soliciting Potential

Major Donor 
cont'd.

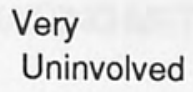

Soliciting Potential

Donor

Evaluating Fund

Raising Programs

Establishing Fund

Raising Policy

7. Do you as dean feel that your office is providing adequate support for the school's development program based on your view of what is achievable?

Yes

No

Please comment about what is most and least effectively done. 


\section{FUND RAISING METHODS AND TECHNIQUES}

8. How important is it that the entire school community and all constituencies clearly understand the role of the development office in support of institutional objectives?

$\begin{array}{llll}\text { Very } & \text { Generally } & \text { Generally } & \text { Very } \\ \text { Unimportant } & \text { Unimportant } & \text { Important } & \text { Important }\end{array}$

9. How effective has the development office been in clearly communicating its role to the school community and fund raising constituencies?

\begin{tabular}{llll}
$\begin{array}{l}\text { Very } \\
\text { Ineffective }\end{array}$ & $\begin{array}{l}\text { Generally } \\
\text { Ineffective }\end{array}$ & $\begin{array}{l}\text { Generally } \\
\text { Effective }\end{array}$ & $\begin{array}{l}\text { Very } \\
\text { Effective }\end{array}$ \\
\hline
\end{tabular}

10. Does the development office make an effort to notify specific faculty members of contract and grant opportunities?

Yes

No

11. Does the development office motivate faculty members to develop projects and to write proposals?

Yes

No

12. Does the development office become involved in the actual writing of the proposal?

Yes

No

13. How important to development is it for the dean's office to identify and publicize substantive institutional activities that may be identified as important by the community or prospective contributors?

$\begin{array}{llll}\text { Very } & \text { Generally } & \text { Generally } & \text { Very } \\ \text { Unimportant } & \text { Unimportant } & \text { Important } & \text { Important }\end{array}$


14. How effectively does your entire school communicate its case for philanthropic support?

$$
\begin{array}{llll}
\text { Very } & \text { Generally } & \text { Generally } & \text { Very } \\
\text { Ineffectively } & \text { Ineffectively } & \text { Effectively } & \text { Effectively }
\end{array}
$$

15. How effectively does the development office, in conjunction with the dean's office, highlight the accomplishments of alumni, faculty, students and staff?

$\begin{array}{llll}\text { Very } & \text { Generally } & \text { Generally } & \text { Very } \\ \text { Ineffectively } & \text { Ineffectively } & \text { Effectively } & \text { Effectively }\end{array}$

16. How effective is the university's development office in aiding your school's advancement activities?

$\begin{array}{llll}\text { Very } & \text { Generally } & \text { Generally } & \text { Very } \\ \text { Ineffective } & \text { Ineffective } & \text { Effective } & \text { Effective }\end{array}$

17. How important is the public's impression of your school (i.e., the image your institution has in the public's eye) to the development program?

$\begin{array}{llll}\text { Very } & \text { Generally } & \text { Generally } & \text { Very } \\ \text { Unimportant } & \text { Unimportant } & \text { Important } & \text { Important }\end{array}$

18. How much school time or money (emphasis) is spent on improving your school's public image?

$\begin{array}{llll}\text { No } & \text { Minimal } & \text { Moderate } & \text { Heavy } \\ \text { Emphasis } & \text { Emphasis } & \text { Emphasis } & \text { Emphasis }\end{array}$

19. How much time or money (emphasis) is spent on personal visits by the dean to the school's fund raising efforts?

\begin{tabular}{llll} 
No & Minimal & Moderate & Heavy \\
Emphasis & Emphasis & Emphasis & Emphasis \\
\hline
\end{tabular}


20. What do you believe are the major strengths and weaknesses of fund raising efforts in the American schools of dentistry? 
21. Succinctly, what are your perceptions of each of the following:

a. Why do people (e.g., individuals, foundations, etc.) give to schools of dentistry?

b. How do people (e.g., individuals, foundations, etc.) usually give to schools of dentistry?

c. When do people (e.g., special occasion, end of year, etc.) usually give to schools of dentistry? 
22. Demographic Information:
a. Age
b. Male
Female
c. Ethnicity

d. How long have you been dean at this school?

e. How many years have you had significant administrative experience (e.g., dean, associate/assistant dean, department head) in a school of dentistry?

Dean

Associate/

Assistant Dean

Dept. Head

Other

f. What kinds of fund raising experiences (if any) have you had prior to becoming dean (including fund raising activities apart from schools of dentistry?

g. Is there other information about yourself that you believe would be useful to share that is relevant to the topic of advancement activities at your school or at American schools of dentistry generally?

I sincerely appreciate your efforts. Thank you ! 
APPENDIX

G 


\section{AMERICAN SCHOOLS OF DENTISTRY \\ ADVANCEMENT ACTIVITIES QUESTIONNAIRE \\ FOR SCHOOL DEVELOPMENT OFFICERS}

Thank you for participating in this research project. In cooperation with the American Association of Dental Schools, I am conducting a survey of advancement activities among American schools of dentistry. It is my intention to identify successful fund raising methods and techniques, synthesize, and disseminate this information through the association. All responses will be kept confidential and the name of your institution will remain anonymous.

Please complete the following questionnaire and return by August 23, 1991 in the envelope provided. Do not leave any item blank. If a question does not pertain to your institution, please signify by marking it NA.

If you wish to elaborate any answer, please do not hesitate to do so on the back of the page and mark the particular question accordingly. If you desire a summary of the findings after the completion of the study, please indicate:

Yes__ No

Thank you for your cooperation.

Questionnaire Completed By:

Name:

Title:

Institution:

Location: Date:

ADVANCEMENT ACTIVITIES QUESTIONNAIRE

This questionnaire is composed of four sections:

Institutional information;

Organizational structure and management practices;

Fund raising sources, constituencies, and record keeping; and

Fund raising methods and techniques.

Most items can be completed with check marks. 
INSTITUTIONAL INFORMATION

Name

Location

Enrollment (Academic 1989-90):

Number/Pre-Doctoral

Number/Post-Doctoral

Other

Faculty:

Number/Full-Time (FTE)

Number/Part-Time

Number/Volunteers

Other

Budget (FY 1989-90):

Revenues (FY 1989-90):

Tuition/Fees

Patient Care

Gifts

Endowments

Grants/Contracts

Other 
INSTITUTIONAL INFORMATION

Name

Location

Enrollment (Academic 1990-91):

Number/Pre-Doctoral

Number/Post-Doctoral

Other

Faculty:

Number/Full-Time (FTE)

Number/Part-Time

Number/Volunteers

Other

Budget (FY 1990-91):

Revenues (FY 1990-91):

Tuition/Fees

Patient Care

Gifts

Endowments

Grants/Contracts

Other 


\section{ORGANIZATIONAL STRUCTURE AND MANAGEMENT PRACTICES}

1. Does your school have a separate development office?

Yes No

If not, on the backside of this page or on a separate sheet, please describe where school advancement activities are centralized and answer other portions of the survey as applicable.

2. In what year was the development office organized?

Year

On the backside of this page or on a separate sheet, please indicate the school's organizational chart. Show as appropriate, the relationship of the school administration/development office, the alumni, and the university administration/development office. (Please enclose a printed organizational chart if available.)

3. What is the title of the school development officer?

Title:

4. To what administrative officer does he or she report?

Reports to:

5. How often does the school development officer report directly to the administrative officer mentioned in Item 4 (please check one answer)?

Daily

Weekly

Monthly

Bi-Monthly

Quarterly

Semi-Annually

Annually 
6. How many professional and support staff does the school's development office have?

Professional

Staff

7. How many years experience does the school development officer have as a development professional?

Years

8. How long has the school development officer been in his/her current post at this school?

Years

9. Duties which are also the responsibility of the school development office include:

Alumni Relations

Donor Advisory Committee

Special Events

Publications/Periodicals

Publicity/Public

Information

Other

10. Approximately what percentage of the staff's time is devoted to fund raising activities?

$\%$

11. Does the school have a formal case statement (published development document) which outlines the goals of the school, the purpose of raising private voluntary support and describes how private support will be utilized by the school?
Yes
No

(Please enclose a printed case statement if available.) 
12. How involved is each of the following in the development of the school's case statement?

$\begin{array}{llll}\text { Very } & \text { Generally } & \text { Generally } & \text { Very } \\ \text { Uninvolved } & \text { Uninvolved } & \text { Involved } & \text { Involved }\end{array}$

Dean

School Development

Officer

Associate/Assistant

Deans

Dept. Chairs/

Faculty

Alumni Support

Groups

University Adm./

Development

Other (Please Specify)

13. Is a written annual development plan, with projected goals, prepared and presented for approval?

Yes__ No

To Whom?

By Whom?

14. Are school needs and fund raising goals projected for several years?

Yes

No

By Whom? 
15. Please succinctly describe the management technique employed in the development program at your school, how long it has been used, and briefly evaluate its effectiveness.

16. Approximately how much money is budgeted, spent, or in other ways provided in support of fund raising for the school on an annual basis by the school and/or university? (Total should roughly include professional and staff costs, supplies, etc.)

Estimated Total Costs

For Development Program:

$(1988-89)$

$(1989-90)$

$(1990-91)$ 
17. How effective is the school in providing an adequate operating budget for the development office?

$\begin{array}{llll}\text { Very } & \text { Generally } & \text { Generally } & \text { Very } \\ \text { Ineffective } & \text { Ineffective } & \text { Effective } & \text { Effective }\end{array}$

18. Is the school development officer responsible for budget preparation in advancement activities?

$$
\text { Yes_ No }
$$

19. Do you think the advancement budget is at or above average for schools of your size and type (private/public)?

Yes_ No

20. Does the school's information system provide a monthly expenditure report?

Yes

No

21. How involved is each of the following in evaluating the school's fund raising program?

$\begin{array}{llll}\text { Very } & \text { Generally } & \text { Generally } & \text { Very } \\ \text { Uninvolved } & \text { Uninvolved } & \text { Involved } & \text { Involved }\end{array}$

Dean

School Development

Officer

Associate/Assistant

Deans

Department Chairs/

Faculty

Alumni Support

Groups

University Adm.I

Development

Other (Please Specify) 
22. Please identify the importance of the following criteria in evaluating the school's fund raising program.

$\begin{array}{llll}\text { Very } & \text { Generally } & \text { Generally } & \text { Very } \\ \text { Unimportant } & \text { Unimportant } & \text { Important } & \text { Important }\end{array}$

Total Funds Raised

Percent Increase in Funds

Number of Contributors

Number of Volunteer

Workers

Other (Please Specify)

23. Is an annual report prepared?

Yes__ No

To Whom Is It Made?

\section{FUND RAISING SOURCES, CONSTITUENCIES, AND RECORD KEEPING}

24. How effective are the following constituencies in providing funds to support your school?

$\begin{array}{llll}\text { Very } & \text { Generally } & \text { Generally } & \text { Very } \\ \text { Ineffective } & \text { Ineffective } & \text { Effective } & \text { Effective }\end{array}$

Alumni
Non-Alumni Friends
Faculty and Staff
Parents
Business and Industry
Private Foundations
Clubs and Organizations
Other (Please Specify)


25. How much development time or money (emphasis) is spent by the development office in seeking funds from the following sources?

$\begin{array}{llll}\text { No } & \text { Minimal } & \text { Moderate } & \text { Heavy } \\ \text { Emphasis } & \text { Emphasis } & \text { Emphasis } & \text { Emphasis }\end{array}$

Major Gift Programs

Annual Fund

Deferred (Planned) Gifts

Capital Projects

Alumni

Non-Alumni Friends

Faculty and Staff

Parents

Business and Industry

Clubs and Organizations

Other (Please Specify)

26. Is there an organized system in place to identify individuals, corporations or foundations interested in your school?

Yes

No

General Examples

27. What office is responsible for the maintenance of development records (donor and prospect files)?

Dean

Development

Other (Please Specify) 
28. How are development records stored?

Development Computer

School Computer

University Computer

Other (Please Specify)

29. How many records (total number of all names on mailing lists) are stored? $1-5,000$

$5,001-10,000$

$10,001-20,000$

Over 20,000

30. Does the school's records reflect occupational information, history of giving, or other pertinent facts concerning prospective contributors?

Yes__ No

31. Are prospects rated and evaluated as to giving-potential?

Yes

No

32. Which of the following prospective contributors are presently in the school's donor research file?

Alumni

Non-Alumni Friends

Faculty and Staff

Parents

Business and Industry

Private Foundations

Clubs and Organizations

"Alumni" of Special Programs

(e.g., A Graduate Orthodontic Program) 
33. How often are records updated?

Monthly

Bi-Monthly

Quarterly

Semi-Annually

Annually

As Needed Only

34. How often is an analysis of prior giving by individual and/or other constituencies done?

Monthly

Bi-Monthly

Quarterly

Semi-Annually

Annually

As Needed

35. How effective (or efficient) is the school's system in recording and acknowledging all gifts received?

$\begin{array}{llll}\text { Very } & \text { Generally } & \text { Generally } & \text { Very } \\ \text { Ineffective } & \text { Ineffective } & \text { Effective } & \text { Effective }\end{array}$




\section{FUND RAISING METHODS AND TECHNIQUES}

36. How involved is the dean in the following advancement activities?

$\begin{array}{lllll} & \text { Very } & \text { Generally } & \text { Generally } & \text { Very } \\ & \text { Uninvolved } & \text { Uninvolved } & \text { Involved } & \text { Involved }\end{array}$

Providing Effective

Leadership

Seeking Financial

Support

Identifying, Recruiting, and Involving Volunteer

Leadership

Soliticting Potential

Major Donor

Soliciting Potential

Donor

Evaluating Fund

Raising Programs

Establishing Fund

Raising Policy

37. How involved are all or most of the Assistant/Associate Deans in the following advancement activities?

$\begin{array}{lllll}\begin{array}{l}\text { Pery } \\ \text { Providing Effective } \\ \text { Leadership }\end{array} & \begin{array}{l}\text { Generally } \\ \text { Uninvolved }\end{array} & \begin{array}{l}\text { Generally } \\ \text { Involved }\end{array} & \begin{array}{l}\text { Very } \\ \text { Involved }\end{array} \\ \text { Seeking Financial } \\ \text { Support }\end{array}$


cont'd.

Evaluating Fund

Raising Programs

Establishing Fund

Raising Policy

38. How involved are all or most members of the department chairs/faculty in the following advancement activities?

\begin{tabular}{|c|}
\hline $\begin{array}{l}\text { Very } \\
\text { Uninvolved }\end{array}$ \\
\hline
\end{tabular}

\section{Providing Effective \\ Leadership \\ Seeking Financial \\ Support}

Identifying, Recruiting

and Involving Volunteer

Leadership

Soliciting Potential

Major Donor

Soliciting Potential

Donor

Evaluating Fund

Raising Programs

Establishing Fund

Raising Policy

39. How involved are all or most members of the alumni support groups in the following advancement activities?

$\begin{array}{llll}\text { Very } & \text { Generally } & \text { Generally } & \text { Very } \\ \text { Uninvolved } & \text { Uninvolved } & \text { Involved } & \text { Involved }\end{array}$

Providing Effective

Leadership

Seeking Financial

Support 
cont'd.

Very

Uninvolved

\section{Generally}

Uninvolved
Generally

Involved
Very

Involved

Identifying, Recruiting

and Involving Volunteer

Leadership

Soliciting Potential

Major Donor

Soliciting Potential

Donor

Evaluating Fund Raising

Programs

Establishing Fund

Raising Policy

40. How involved in the following school advancement activities is the university development office?

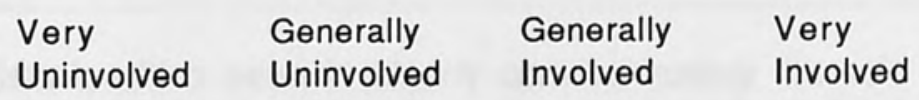

Providing Effective

Leadership

Seeking Financial

Support

Identifying, Recruiting and Involving Volunteer

Leadership

Soliciting Potential

Major Donor

Soliciting Potential

Donor

Evaluating Fund

Raising Programs

Establishing Fund

Raising Policy 
41. How important is it that the relationship between the school's development office and the university's development office be coordinated organizationally in order to enhance fund raising potential?

$\begin{array}{llll}\text { Very } & \text { Generally } & \text { Generally } & \text { Very } \\ \text { Unimportant } & \text { Unimportant } & \text { Important } & \text { Important }\end{array}$

42 At your school, how effective is the coordination mentioned above in Item 41 ?

$\begin{array}{llll}\text { Very } & \text { Generally } & \text { Generally } & \text { Very } \\ \text { Ineffective } & \text { Ineffective } & \text { Effective } & \text { Effective }\end{array}$

43. Succinctly, describe the school's organizational relationship to central university development. What are the strengths and weaknesses of the relationship?

44. How effective has the dean's office been in clearly communicating the role of the development office to the entire school community and, most important, fund raising constituencies?

$\begin{array}{llll}\text { Very } & \text { Generally } & \text { Generally } & \text { Very } \\ \text { Ineffective } & \text { Ineffective } & \text { Effective } & \text { Effective }\end{array}$

45. How important to development is it for the dean's office to help plan and coordinate fund raising campaigns?

$\begin{array}{llll}\text { Very } & \text { Generally } & \text { Generally } & \text { Very } \\ \text { Unimportant } & \text { Unimportant } & \text { Important } & \text { Important }\end{array}$

46. As an assist to the development office, how active has the dean's office been in identifying and publicizing substantive institutional activities that may be considered important by the community or prospective contributors?

\begin{tabular}{llll}
$\begin{array}{l}\text { Very } \\
\text { Inactive }\end{array}$ & $\begin{array}{l}\text { Generally } \\
\text { Inactive }\end{array}$ & $\begin{array}{l}\text { Generally } \\
\text { Active }\end{array}$ & $\begin{array}{l}\text { Very } \\
\text { Active }\end{array}$ \\
\hline
\end{tabular}


47. How active has the development office been in cultivating or emphasizing corporate/business matching gifts for dollars contributed?

$\begin{array}{llll}\text { Very } & \text { Generally } & \text { Generally } & \text { Very } \\ \text { Inactive } & \text { Inactive } & \text { Active } & \text { Active }\end{array}$

48 How much development program time or money (emphasis) is spent on improving your school's public image?

$\begin{array}{llll}\text { No } & \text { Minimal } & \text { Moderate } & \text { Heavy } \\ \text { Emphasis } & \text { Emphasis } & \text { Emphasis } & \text { Emphasis }\end{array}$

49. How effective is the school's on-going potential donor identification (i.e., prospect research) process or system?

\begin{tabular}{llll}
$\begin{array}{l}\text { Very } \\
\text { Ineffective }\end{array}$ & $\begin{array}{l}\text { Generally } \\
\text { Ineffective }\end{array}$ & $\begin{array}{l}\text { Generally } \\
\text { Effective }\end{array}$ & $\begin{array}{l}\text { Very } \\
\text { Effective }\end{array}$ \\
\hline
\end{tabular}

50. How involved are alumni in the school's on-going potential donor identification (i.e., prospect research) practices?

$\begin{array}{llll}\text { Very } & \text { Generally } & \text { Generally } & \text { Very } \\ \text { Uninvolved } & \text { Uninvolved } & \text { Involved } & \text { Involved }\end{array}$

51. How much time or money (emphasis) is spent on prospect research and potential donor identification?

$\begin{array}{llll}\text { No } & \text { Minimal } & \text { Moderate } & \text { Heavy } \\ \text { Emphasis } & \text { Emphasis } & \text { Emphasis } & \text { Emphasis }\end{array}$


52. Is the school development officer responsible for the market research of potential donors?

$$
\text { Yes___ No }
$$

53. How important are personal visits to the school's fund raising efforts?

$\begin{array}{llll}\text { Very } & \text { Generally } & \text { Generally } & \text { Very } \\ \text { Unimportant } & \text { Unimportant } & \text { Important } & \text { Important }\end{array}$

54. How much time or money (emphasisis) spent on personal visits by development officers?

$$
\begin{array}{llll}
\text { No } & \text { Minimal } & \text { Moderate } & \text { Heavy } \\
\text { Emphasis } & \text { Emphasis } & \text { Emphasis } & \text { Emphasis }
\end{array}
$$

55. How important is it that the development office establish the following types of fund raising goals?

$\begin{array}{llll}\text { Very } & \text { Generally } & \text { Generally } & \text { Very } \\ \text { Unimportant } & \text { Unimportant } & \text { Important } & \text { Important }\end{array}$

Higher than

Previous

Years Goals

Significantly

Higher Than

Previous Years

Goals

Inflation plus

$5-10 \%$

Major Effort Based

On an Anniversary

(Or the Like)

Realistic

Expectations 
56. How important is it that major gifts (i.e., $\$ 25,000$ or more annually) be actively solicited on a personal basis?

$\begin{array}{llll}\text { Very } & \text { Generally } & \text { Generally } & \text { Very } \\ \text { Unimportant } & \text { Unimportant } & \text { Important } & \text { Important }\end{array}$

57. Does the school's development office use volunteers to solicit funds?

Yes

No

If so, how does the school's development office recruit them?

58. How effective are the following methods and techniques in optimizing the school's fund raising effort? (Only respond for methods and techniques currently being used.)

$\begin{array}{llll}\text { Very } & \text { Generally } & \text { Generally } & \text { Very } \\ \text { Ineffective } & \text { Ineffective } & \text { Effective } & \text { Effective }\end{array}$

Printed Brochures

Computerized Letters

Personalized Letters

Humor in Printed

Material

Annual Themes

Suggested Gift Amounts

Designated Gifts

Class Agent System

Class Reunion Giving

Phoning By Students

Phoning By Alumni 
cont'd.

Personal Visits

Special Gift Program

Outside Professional

Counsel

Prospect Research

Case Statements

Organized Groups

Of Friends

Other (Please Specify)

59. Funds raised from private sources can be designated for many uses. How attractive to the donor is each of the following in positively influencing them to contribute?

$\begin{array}{llll}\text { Very } & \text { Generally } & \text { Generally } & \text { Very } \\ \text { Unattractive } & \text { Unattractive } & \text { Attractive } & \text { Attractive }\end{array}$

Scholarships

Endowment

Specific Academic

Areas

Library Acquisitions

Endowed Chairs

Faculty Projects

Special Programs

Capital Projects

Gift-In-Kind

Research
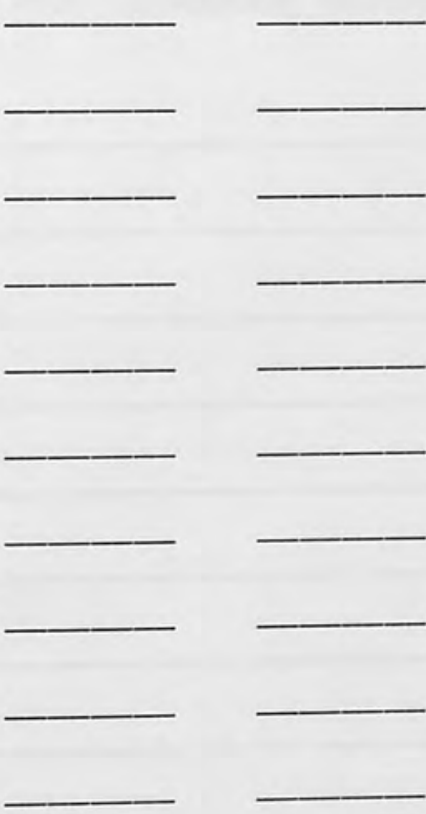

Other (Please Describe) 
60. What type of fund raising strategy do you consider the school's most successful and why? (i.e., annual, capital, deferred, etc.).

61. What do you feel are the most outstanding features of the school's total fund raising program? 
62. Succinctly, what are your perceptions of each of the following:

a. Why do people (e.g., individuals, foundations, etc.) give to schools of dentistry?

b. How do people (e.g., individuals, foundations, etc.) usually give to schools of dentistry?

c. When do people (e.g., special occasion, end of year, etc.) usually give to schools of dentistry? 
63. Demographic Information:

a. Age

b. Male

Female

c. Ethnicity

d. How long have you been the development officer at this school?

e. How many years have you had significant administrative experience as a development officer in a school of dentistry?

f. What kinds of fund raising experiences have you had prior to assuming your current position as the school's development officer (including fund raising activities apart from schools of dentistry)?

g. Is there other information about yourself that you believe would be useful to share that is relevant to the topic of advancement activities at your school or at American schools of dentistry generally?

I sincerely appreciate your efforts. Thank you 
APPENDIX

H

278 
September 10, 1991

Dean Henry M. Cherrick

School of Dentistry

University of California, Los Angeles

Center for Health Sciences

Los Angeles, CA 90024-1668

\section{Dear Dean Cherrick:}

I am writing in regards to a research project I am conducting at the Claremont Graduate School dealing with the subject of advancement activities in American schools of dentistry.

The purpose of the study is to establish a set of criteria for a model development program by an in-depth analysis of the organization, management, methods, and effectiveness of fund raising at American schools of dentistry. Since adequate financial support is a major concern facing American schools of dentistry, I believe the study will provide constructive information on effective fund raising methods for schools of dentistry.

Your school was among a select group of institutions chosen to participate in the personal interview portion of the study. The interviews are designed to elicit information elaborative of data provided in the returned, completed questionnaires. Hence, I would like to make a half-day visit to your school to talk with you and the school's development officer, Catherine Cosgrove.

All information provided by participants in the interview/study will be strictly confidential and not identified with the school to which it was related. Once the study is completed, I shall send you a summary of the findings.

Sometime within the next week, I shall telephone your office to arrange an appointment which is convenient for you and Catherine Cosgrove. If you have any questions before I call, please feel free to contact me at (714) 621-8075.

Thank you. Your cooperation is greatly appreciated.

Sincerely,

Frank C. Flores, Jr., D.D.S., M.S.

Director, Project on Advancement Activities in American Schools of Dentistry 
September 10, 1991

Catherine Cosgrove

Director of Development

School of Dentistry

University of California, Los Angeles

Center for Health Sciences 53-038

Los Angeles, CA 90024-1668

Dear Cathy:

I am writing in regards to a research project I am conducting at the Claremont Graduate School dealing with the subject of advancement activities in American schools of dentistry.

The purpose of the study is to establish a set of criteria for a model development program by an in-depth analysis of the organization, management, methods, and effectiveness of fund raising at American schools of dentistry. Since adequate financial support is a major concern facing American schools of dentistry, I believe the study will provide constructive information on effective fund raising methods for schools of dentistry.

Your school was among a select group of institutions chosen to participate in the personal interview portion of the study. The interviews are designed to elicit information elaborative of data provided in the returned, completed questionnaires. Hence, I would like to make a half-day visit to your school to talk with you and Dean Henry Cherrick.

All information provided by participants in the interview/study will be strictly confidential and not identified with the school to which it was related. Once the study is completed, I shall send you a summary of the findings.

Sometime within the next week, I shall telephone your office to arrange an appointment which is convenient for you and Dean Cherrick. If you have any questions before I call, please feel free to contact me at (714) 621-8075.

Thank you. Your cooperation is greatly appreciated.

Sincerely,

Frank C. Flores, Jr., D.D.S., M.S.

Director, Project on Advancement Activities in American Schools of Dentistry 
APPENDIX

I

281 
INTERVIEW GUIDE FOR DENTAL DEANS

Name:

Title:

Institution:

Location:

Date: 
1. How active has the school been in performing each of the following tasks?

$\begin{array}{lllll}\text { Very } & \text { Generally } & \text { Generally } & \text { Very } & \text { Not } \\ \text { Inactive } & \text { Inactive } & \text { Active } & \text { Active } & \text { Applicable }\end{array}$

a. Having the development officer visit major funding prospects?

b. Having the dean visit major funding prospects?

c. Submitting proposals to major funding prospects?

d. Making follow-up contacts with a major funding prospect after submitting a proposal?

e. Doing follow-up work on proposals rejected by major funding prospects?

Comments: 
2. How successful has the school been in each of the following:

$\begin{array}{lllll}\text { Very } & \text { Generally } & \text { Generally } & \text { Very } & \text { Not } \\ \text { Unsuccessful } & \text { Unsuccessful } & \text { Successful } & \text { Successful } & \text { Apolicable }\end{array}$

a. Obtaining grants for the

Proposals submitted to funding prospects

b. Finding out why a proposal was not funded by a funding prospect

c. Obtaining grants for the amount requested in the proposal

Comments: 
3. How helpful would you say the following institutional features have been to the school in its attempt to obtain philanthropic support from 1987-88 to 1990-91?

$\begin{array}{lllll}\text { Very } & \text { Generally } & \text { Generally } & \text { Very } & \text { Not } \\ \text { Unhelpful } & \underline{\text { Unhelpful }} & \text { Helpful } & \text { Helpful } & \text { Applicable }\end{array}$

a. School's geographic location

b. School's university affiliation

c. School's historical background/development

d. School having a balanced budget

e. Level of school's indebtedness

f. School's strategic plan

g. Size of school's enrollment

\section{Comments:}


4. How helpful have the following development office features been to the school in its attempt to obtain philanthropic support from 1987-88 to 1990-91?

\begin{tabular}{lllll} 
Very & Generally & Generally & Very & Not \\
Unhelpful & Unhelpful & Helpful & Helpful & Applicable \\
\hline
\end{tabular}

a. Tenure of the chief development officer

b. Professional background of the senior development officer

c. Number of full-time staff employed by the development office

d. Amount of time the development staff spends researching funding prospects

e. Strategic planning done by the development office

f. Number of proposals submitted to funding prospects

g. Quality of proposals submitted to funding prospects
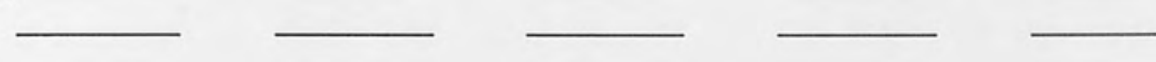

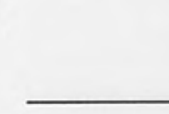


5. How often did you, as dean, participate in the following activities in the last academic year?

$\begin{array}{lllll}\text { Within } & \text { Within } & \text { Within } & \text { Within } & \text { Not } \\ 1-3 & 4-6 & 7-9 & 10-12 & \text { Applic- } \\ \text { Months } & \text { Months } & \text { Months } & \text { Months } & \text { able }\end{array}$

a. Meeting with the development officer to discuss a possible grant application by the school

b. Visiting a major funding prospect to make a request for funds

c. Discussing potential sources of philantropic support with the school's development officer

d. Meeting with volunteers to discuss assisting the school with its advancement activities

Comments: 
Finally, I would like to conclude our interview by asking you the following general questions regarding your perceptions of the school's advancement activities from 1987-88 to 1990-91?

6. What has been your primary role, as dean, with the school's fund raising efforts?

7. What has been your main frustration with the school's fund raising efforts?

8. What have been the outstanding features of fund raising efforts of your school? 
9. What should the school do to improve its ability to obtain philanthropic support?

10. Succinctly describe the role gifts from philanthropic support have played in the life of the school?

Thank you for sharing your valuable time and your perceptions on advancement activities at your school. 
APPENDIX

J

290 
INTERVIEW GUIDE FOR DENTAL DEVELOPMENT OFFICERS

Name:

Title:

Institution:

Location:

Date: 
1. How active has the school been in performing each of the following tasks?

$\begin{array}{lllll}\text { Very } & \text { Generally } & \text { Generally } & \text { Very } & \text { Not } \\ \text { Inactive } & \text { Inactive } & \text { Active } & \text { Active } & \text { Applicable }\end{array}$

a. Having the development officer visit major funding prospects?

b. Having the dean visit major funding prospects?

c. Submitting proposals to major funding prospects?

d. Making follow-up contacts with a major funding prospect after submitting a proposal?

e. Doing follow-up work on proposals rejected by major funding prospects?

Comments: 
2. How successful has the school been in each of the following:

$\begin{array}{lllll}\text { Very } & \text { Generally } & \text { Generally } & \text { Very } & \text { Not } \\ \text { Unsuccessful: } & \text { Unsuccessful } & \text { Successful } & \text { Successful } & \text { Applicable }\end{array}$

a. Obtaining grants for the proposals submitted to funding prospects

b. Finding out why a proposal was not funded by a funding prospect

c. Obtaining grants for the amount requested in the proposal

Comments: 
3. How helpful would you say the following institutional features have been to the school in its attempt to obtain philanthropic support from 1987-88 to $1990-91$ ?

\begin{tabular}{lllll} 
Very & Generally & Generally & Very & Not \\
Unhelpful & $\underline{\text { Unhelpful }}$ & Helpful & Helpful & Applicable \\
\hline
\end{tabular}

a. School's geographic location

b. School's university affiliation

c. School's historical background/development

d. School having a balanced budget

e. Level of school's indebtedness

f. School's strategic plan

g. Size of school's enrollment

\section{Comments:}


4. How helpful have the following development office features been to the school in its attempt to obtain philanthropic support from 1987-88 to 1990-91?

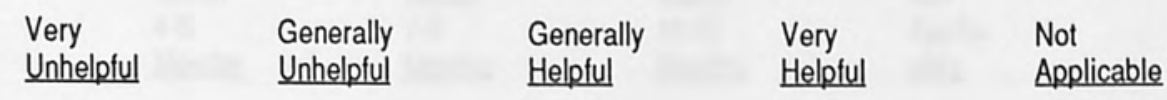

a. Tenure of the senior development officer

b. Professional background of the senior development officer

c. Number of full-time staff employed by the development office

d. Amount of time the development staff spends researching funding prospects

e. Strategic planning done by the development office

f. Number of proposals submitted to funding prospects

g. Quality of proposals submitted to funding prospects

Comments: 
5. How often did you, as development officer, participate in the following activities in the last academic year?

$\begin{array}{lllll}\text { Within } & \text { Within } & \text { Within } & \text { Within } & \text { Not } \\ 1-3 & 4-6 & 7-9 & 10-12 & \text { Applic- } \\ \text { Months } & \text { Months } & \text { Months } & \text { Months } & \text { able }\end{array}$

a. Meeting with the dean to discuss a possible grant application by the school

b. Visiting a major funding prospect to make a request for funds

c. Discussing potential sources of philanthropic support with the school's dean

d. Talking with volunteers about helping the school with its advancement activities

Comments: 
Finally, I would like to conclude our interview by asking you the following general questions regarding your perceptions of the school's advancement activities from $1987-88$ to $1990-91$ ?

6. What has been your primary role, as development officer, with the school's fund-raising efforts?

7. What has been your main frustration with the school's fund raising efforts?

8. What have been the outstanding features of fund raising efforts of your school? 
9. What should the school do to improve its ability to obtain philanthropic support?

10. Succinctly describe the role gifts from philanthropic support have played in the life of the school?

Thank you for sharing your valuable time and your perceptions on advancement activities at your school. 
APPENDIX K 
September 19, 1991

Dean Henry M. Cherrick

School of Dentistry

University of California, Los Angeles

Center for Health Sciences

Los Angeles, CA 90024-1668

\section{Dean Dean Cherrick:}

I want to thank you for the opportunity to talk with you concerning my research on advancement activities in American schools of dentistry. Also, I want to confirm my appointment with you on Wednesday, October 16th at 9:00 a.m.

As I indicated in my initial letter, the purpose of the study is to gather information on factors which have helped American schools of dentistry obtain philanthropic support. Most of my questions will be concerned with your perception on advancement activities at your school.

If agreeable with you, I would like to tape record our discussion. This will allow me to listen to our conversation several times and accurately report what was discussed. Also, I shall not have to devote so much time to writing and, therefore, will be able to listen more attentatively to what you have to say about advancement activities at your school.

I would like to point out, I shall use a recorder only if you grant me permission. You can be assured that I shall be the only person listening to the recording, and it will be destroyed once I have completed the study.

Again, thank you for the opportunity to talk with you regarding a very important issue confronting American schools of dentistry. If you have any questions before my visit, please contact me at (714) 621-8075.

Regards,

Frank C. Flores, Jr., D.D.S., M.S.

Director, Project on Advancement Activities in American Schools of Dentistry 


\section{The Claremont Graduate School}

September 20, 1991

Catherine Cosgrove

Director of Development

School of Dentistry

University of California, Los Angeles

CHS 53-038

Los Angeles, CA 90024-1668

Dean Ms. Cosgrove:

I want to thank you for the opportunity to talk with you concerning my research on advancement activities in American schools of dentistry. Also, I want to confirm my appointment with you on Wednesday, October 16th at 10:00 a.m.

As I indicated in my initial letter, the purpose of the study is to gather information on factors which have helped American schools of dentistry obtain philanthropic support. Most of my questions will be concerned with your perception on advancement activities at your school.

If agreeable with you, I would like to tape record our discussion. This will allow me to listen to our conversation several times and accurately report what was discussed. Also, I shall not have to devote so much time to writing and, therefore, will be able to listen more attentatively to what you have to say about advancement activities at your school.

I would like to point out, I shall use a recorder only if you grant me permission. You can be assured that I shall be the only person listening to the recording, and it will be destroyed once I have completed the study.

Again, thank you for the opportunity to talk with you regarding a very important issue confronting American schools of dentistry. If you have any questions before my visit, please contact me at (714) 621-8075.

Regards,

Frank C. Flores, Jr., D.D.S., M.S.

Director, Project on Advancement Activities in American Schools of Dentistry 
APPENDIX

L

302 
DEAN SURVEY

INSTITUTIONAL INFORMATION

VARIABLE: PRE-DOCTORAL ENROLLMENT (1989-90)

\begin{tabular}{|c|c|c|c|}
\hline Value Label & Value & Erequency & Percent \\
\hline $80-149$ & 1 & 3 & 09.4 \\
\hline $150-219$ & 2 & 9 & 28.1 \\
\hline $220-289$ & 3 & 5 & 15.6 \\
\hline $290-359$ & 4 & 9 & 28.1 \\
\hline $360-429$ & 5 & 2 & 06.3 \\
\hline $430-499$ & 6 & 0 & 00.0 \\
\hline $500-950$ & 7 & 1 & 03.1 \\
\hline (Missing) & 9 & 3 & 09.4 \\
\hline & & 32 & 100.0 \\
\hline
\end{tabular}

MEAN: 3.069

STD DEV: 1.387

VARIABLE: POST-DOCTORAL ENROLLMENT (1989-90)

\begin{tabular}{|c|c|c|c|}
\hline Value Label & Value & Erequency & Percent \\
\hline $6-24$ & 1 & 6 & 18.8 \\
\hline $25-39$ & 2 & 7 & 21.9 \\
\hline $40-54$ & 3 & 6 & 18.8 \\
\hline $55-69$ & 4 & 2 & 06.3 \\
\hline $70-84$ & 5 & 3 & 09.4 \\
\hline $85-99$ & 6 & 2 & 06.3 \\
\hline $100-195$ & 7 & 0 & 00.0 \\
\hline (Missing) & 9 & $\underline{6}$ & 18.8 \\
\hline & & 32 & 100.0 \\
\hline
\end{tabular}

MEAN: 2.808

STD DEV: 1.575 
VARIABLE: FACULTY / FTE (1989-90)

Value Label

25-54

$55-74$

$75-94$

95-114

$115-134$

$135-185$

(Missing)

Total

MEAN: 2.414

\section{VARIABLE: FACULTY / PART-TIME (1989-90)}

Value Label

$3-44$

45-79

80-114

115-149

150-184

$185-219$

$220-250$

(Missing)

Total

MEAN: 2.621

\begin{tabular}{|c|c|c|c|}
\hline & Value & Erequency & Percent \\
\hline & 1 & 10 & 31.3 \\
\hline & 2 & 7 & 21.9 \\
\hline & 3 & 6 & 18.8 \\
\hline & 4 & 3 & 09.4 \\
\hline & 5 & 2 & 06.3 \\
\hline & 6 & 1 & 03.1 \\
\hline & 9 & $\underline{3}$ & 09.4 \\
\hline Total & & 32 & 100.0 \\
\hline
\end{tabular}

STDDEV: 1.427

$\begin{array}{ccc}\text { Value } & \text { Erequency } & \text { Percent } \\ 1 & 13 & 40.6 \\ 2 & 5 & 15.6 \\ 3 & 1 & 03.1 \\ 4 & 4 & 12.5 \\ 5 & 3 & 09.4 \\ 6 & 2 & 06.3 \\ 7 & 1 & 03.1 \\ 9 & 3 & 09.4 \\ & 32 & 100.0\end{array}$

STDDEV: 1.916 
Value Label

(Millions)
$4-11$
$12-14$
$15-17$
$18-20$
$21-23$
$24-26$
$27-37$
(Missing) Total

MEAN: 2.417

$\begin{array}{ccc}\text { Value } & \text { Erequency } & \text { Percent } \\ 1 & 10 & 31.3 \\ 2 & 5 & 15.6 \\ 3 & 3 & 09.4 \\ 4 & 3 & 09.4 \\ 5 & 2 & 06.3 \\ 6 & 0 & 00.0 \\ 7 & 1 & 03.1 \\ 9 & 8 & 25.0 \\ & 32 & 100.0\end{array}$

STD DEV: 1.666

VARIABLE: TUITION-FEES / REVENUES (FY 1989-90)

\begin{tabular}{|c|c|c|c|}
\hline (Thousands) & Value & Erequency & Percent \\
\hline 300-3999 & 1 & 17 & 53.1 \\
\hline $4000-6999$ & 2 & 4 & 12.5 \\
\hline $7000-9999$ & 3 & 1 & 03.1 \\
\hline $10000-12999$ & 4 & 2 & 06.3 \\
\hline $13000-15999$ & 5 & 0 & 00.0 \\
\hline $16000-19999$ & 6 & 1 & 03.1 \\
\hline $20000-24000$ & 7 & 0 & 00.0 \\
\hline \multirow[t]{2}{*}{ (Missing) } & 9 & I & 21.9 \\
\hline & & 32 & 100.0 \\
\hline
\end{tabular}

MEAN: 1.680

STD DEV: 1.282 
Value Label

Thousands)

400-1999

$\begin{array}{cccc} & \text { Value } & \text { Erequency } & \text { Percent } \\ 1 & 13 & 40.6 \\ 2 & 5 & 15.6 \\ 3 & 4 & 12.5 \\ 4 & 4 & 12.5 \\ & 5 & 2 & 06.3 \\ & 6 & 0 & 00.0 \\ \text { Total } & 9 & 4 & 12.5 \\ & & 32 & 100.0\end{array}$

MEAN: 2.179

STD DEV: 1.362

VARIABLE: PRE-DOCTORAL ENROLLMENT (1990-91)

\begin{tabular}{|c|c|c|c|}
\hline Value Label & Value & Erequency & Percent \\
\hline $80-149$ & 1 & 4 & 12.5 \\
\hline $150-219$ & 2 & 6 & 18.8 \\
\hline $220-289$ & 3 & 2 & 06.3 \\
\hline $290-359$ & 4 & 11 & 34.4 \\
\hline $360-429$ & 5 & 2 & 06.3 \\
\hline $430-499$ & 6 & 0 & 00.0 \\
\hline $500-950$ & 7 & 1 & 03.1 \\
\hline (Missing) & 9 & 6 & 18.8 \\
\hline & & 32 & 100.0 \\
\hline
\end{tabular}




\begin{tabular}{|c|c|c|c|}
\hline Value Label & $\underline{\text { Value }}$ & Erequency & Percent \\
\hline $6-24$ & 1 & 6 & 18.8 \\
\hline $25-39$ & 2 & 6 & 18.8 \\
\hline $40-54$ & 3 & 2 & 06.3 \\
\hline $55-69$ & 4 & 5 & 15.6 \\
\hline $70-84$ & 5 & 3 & 09.4 \\
\hline $85-99$ & 6 & 1 & 03.1 \\
\hline $100-195$ & 7 & 0 & 00.0 \\
\hline (Missing) & 9 & $\underline{9}$ & 28.1 \\
\hline & & 32 & 100.0 \\
\hline
\end{tabular}

Value Label
$25-54$
$55-74$
$75-94$
$95-114$
$115-134$
$135-185$
(Missing) Total

MEAN: 2.500

$\begin{array}{ccc}\text { Value } & \text { Erequency } & \text { Percent } \\ 1 & 8 & 25.0 \\ 2 & 4 & 12.5 \\ 3 & 10 & 31.3 \\ 4 & 1 & 03.1 \\ 5 & 3 & 09.4 \\ 6 & 0 & 00.0 \\ 9 & 6 & 18.8 \\ & 32 & 100.0\end{array}$

STD DEV: 1.304 
Value Label

3-44

45-79

80-114

115-149

150-184

185-219

$220-250$

(Missing)

MEAN: 3.077

\begin{tabular}{|c|c|c|}
\hline Value & Erequency & Percent \\
\hline 1 & 9 & 28.1 \\
\hline 2 & 3 & 09.4 \\
\hline 3 & 3 & 09.4 \\
\hline 4 & 4 & 12.5 \\
\hline 5 & 3 & 09.4 \\
\hline 6 & 3 & 09.4 \\
\hline 7 & 1 & 03.1 \\
\hline 9 & 6 & 18.8 \\
\hline & 32 & 100.0 \\
\hline
\end{tabular}

STD DEV: 1.978

VARIABLE: BUDGET (FY 1990-91)

Value Label

(Millions)

4-11

12-14

15-17

$18-20$

21-23

24-26

27-37

(Missing)

$\begin{array}{cccc} & \text { Value } & \text { Erequency } & \text { Percent } \\ 1 & 10 & 31.3 \\ 2 & 2 & 06.3 \\ 3 & 2 & 06.3 \\ 4 & 2 & 06.3 \\ & 5 & 2 & 06.3 \\ & 6 & 2 & 06.3 \\ & 7 & 0 & 00.0 \\ \text { Total } & 9 & 12 & 37.5 \\ & & 32 & 100.0\end{array}$

MEAN: 2.500

STD DEV: 1.850 
Value Label

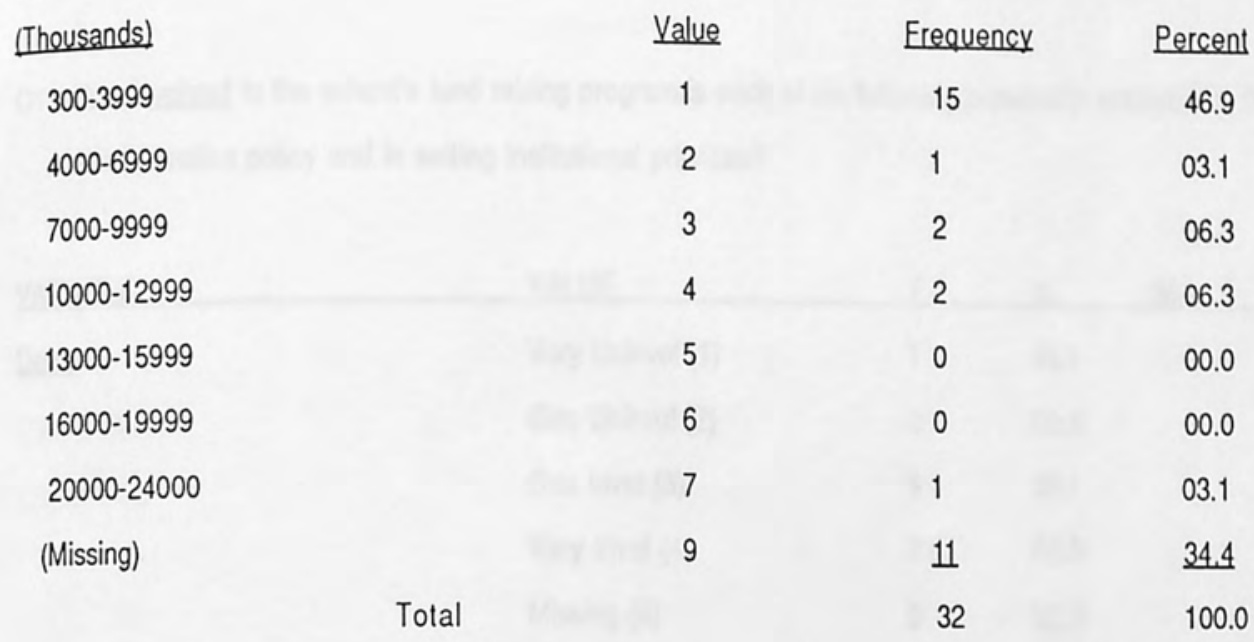

MEAN: 1.810

STD DEV: 1.569

VARIABLE: PATIENT CARE / REVENUES (FY 1990-91)

Value Label

(Thousands)

400-1999

2000-2999

3000-3999

4000-4999

5000-5999

$6000-7000$

(Missing)

$\begin{array}{ccc}\text { Value } & \text { Erequency } & \text { Percent } \\ 1 & 10 & 31.3 \\ 2 & 5 & 15.6 \\ 3 & 3 & 09.4 \\ 4 & 2 & 06.3 \\ 5 & 1 & 03.1 \\ 6 & 1 & 03.1 \\ 9 & 10 & 31.3 \\ & 32 & 100.0\end{array}$




\section{DEAN SURVEY}

\section{ORGANIZATIONAL STRUCTURE AND MANAGEMENT PRACTICES}

Q1 How involved in the school's fund raising program is each of the following persons in establishing the overall administration policy and in setting institutional priorities?

\begin{tabular}{llllll} 
VARIABLE & VALUE & $F$ & $\%$ & $M$ & SD \\
\hline Dean & Very Uninvol (1) & 1 & 03.1 & & \\
Gen Uninvol (2) & 0 & 00.0 & & \\
Gen Invol (3) & 9 & 28.1 & & \\
Very Invol (4) & 22 & 68.8 & & \\
Missing (9) & 0 & $\underline{00.0}$ & & \\
& 32 & 100.0 & 3.625 & 0.660
\end{tabular}

$\begin{array}{llllll}\text { Development } & \text { Very Uninvol (1) } & 1 & 03.1 & & \\ \text { Officer } & \text { Gen Uninvol (2) } & 0 & 00.0 & & \\ & \text { Gen Invol (3) } & 3 & 09.4 & & \\ & \text { Very Invol (4) } & 18 & 56.3 & & \\ \text { Missing (9) } & 10 & \underline{31.3} & & \\ & & 32 & 100.0 & 3.727 & 0.703\end{array}$

Q2 How involved is the development officer and you as dean in the following advancement activities?

$\begin{array}{llllll}\text { VARIABLE } & \text { VALUE } & \text { F } & \% & \text { M } & \text { SD } \\ \text { Dev, Officerl } & \text { Very Uninvol (1) } & 1 & 03.1 & & \\ \text { Leadership- } & \text { Gen Uninvol (2) } & 1 & 03.1 & & \\ \text { Eund Raising } & \text { Gen Invol (3) } & 11 & 34.4 & & \\ & \text { Very Invol (4) } & 10 & 31.3 & & \\ & \text { Missing (9) } & 2 & \underline{28.1} & & \\ & & 32 & 100.0 & 3.304 & 0.765\end{array}$


VARIABLE

Deanl

Seek Funds

Dev. Officerl

Seek Funds

\section{Dev. Officerl}

Solicit

Major Doner
Very Uninvol (1)

Gen Uninvol (2)

Gen Invol (3)

Very Invol (4)

Missing (9)

Very Uninvol (1)

Gen Uninvol (2)

Gen Invol (3)

Very Invol (4)

Missing (9)

VALUE

Very Uninvol (1)

Gen Uninvol (2)

Gen Invol (3)

Missing (9)

Very Uninvol (1)

Gen Uninvol (2)

Gen Invol (3)

Very Invol (4)

Missing (9)

$\begin{array}{cccc}F & \% & M & S D \\ 1 & 03.1 & & \end{array}$

$\begin{array}{ll}0 & 00.0\end{array}$

$12 \quad 37.5$

$\begin{array}{ll}19 & 59.4\end{array}$

$1 \quad 000$

$\begin{array}{llll}32 & 100.0 & 3.531 & 0.671\end{array}$ D

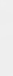




$\begin{array}{llllll}\text { VARIABLE } & \text { VALUE } & \text { F } & \% & \text { M } & \text { SD } \\ \text { Deanl } & \text { Very Uninvol (1) } & 2 & 06.3 & & \\ \text { Evaluate } & \text { Gen Uninvol (2) } & 3 & 09.4 & & \\ \text { Eund Raising } & \text { Gen Invol (3) } & 11 & 34.4 & & \\ & \text { Very Invol (4) } & 16 & 50.0 & & \\ & \text { Missing (9) } & 0 & \underline{00.0} & & \\ & & 32 & 100.0 & 3.281 & 0.888\end{array}$

Dev. Officerl

Evaluate

Eund Raising
Very Uninvol (1)

Gen Uninvol (2)

Gen Invol (3)

Very Invol (4)

Missing (9)

Very Uninvol (1)

Gen Uninvol (2)

Gen Invol (3)

Very Invol (4)

Missing (9)
$2 \quad 06.3$

$1 \quad 03.1$

$\begin{array}{ll}6 & 18.8\end{array}$

$14 \quad 43.8$

$9 \quad 28.1$

$\begin{array}{llll}32 & 100.0 & 3.391 & 0.941\end{array}$

Deanl

Eund Raising

Policy

\section{Dev, Officerl \\ Eund Raising}

Policy

$\begin{array}{llllll}\text { Very Uninvol (1) } & 2 & 06.3 & & \\ \text { Gen Uninvol (2) } & 2 & 06.3 & & \\ \text { Gen Invol (3) } & 10 & 31.3 & & \\ \text { Very Invol (4) } & 9 & 28.1 & & \\ \text { Missing (9) } & 2 & 28.1 & & \\ & 32 & 100.0 & 3.130 & 0.920\end{array}$


Q3 Does the school have a strategic planning process for its overall governance?

\begin{tabular}{llllll} 
VARIABLE & VALUE & F & $\%$ & $M$ & SD \\
\hline Strategic Plan/ & Yes (1) & 30 & 93.8 & & \\
School Gov & No (2) & 2 & 06.3 & & \\
& Missing (9) & 0 & $\underline{00.0}$ & & \\
& & 32 & 100.0 & 1.063 & 0.246
\end{tabular}

Q4 Does the school utilize strategic planning as a management tool for advancement activities?

$\begin{array}{llllll}\text { VARIABLE } & \text { VALUE } & F & \% & M & \text { SD } \\ \text { Strategic Plan/ } & \text { Yes (1) } & 28 & 87.5 & & \\ \text { Fund Raising } & \text { No (2) } & 4 & 12.5 & & \\ & \text { Missing (9) } & 0 & \underline{00.0} & & \\ & & 32 & 100.0 & 1.125 & 0.336\end{array}$

Q5 Do you as dean feel that your office is providing adequate support for the school's development program based on your view of what is achieveable.?

$\begin{array}{llllll}\text { VARIABLE } & \text { VALUE } & \text { F } & \% & \text { M } & \text { SD } \\ \text { Dean / Support } & \text { Yes (1) } & 24 & 75.0 & & \\ \text { Dev. Program } & \text { No (2) } & 6 & 18.8 & & \\ & \text { Missing (9) } & 2 & \underline{06.3} & & \\ & & 32 & 100.0 & 1.200 & 0.407\end{array}$


DEAN SURVEY

\section{FUND RAISING METHODS AND TECHNIQUES}

Q1 How effective has the development office been in clearly communicating its role to the school community and fund raising constituencies?

$\begin{array}{llllll}\text { VARIABLE } & \text { VALUE } & F & \% & M & \text { SD } \\ \text { Dev. Officel } & \text { Very Ineffct (1) } & 1 & 03.1 & & \\ \text { Communicate } & \text { Gen Ineffct (2) } & 5 & 15.6 & \\ \text { Bole } & \text { Gen Effct (3) } & 21 & 65.6 & & \\ & \text { Very Effct (4) } & 4 & 12.5 & & \\ & \text { Missing (9) } & 1 & \underline{03.1} & & \\ & & 32 & 100.0 & 2.903 & 0.651\end{array}$

Q2 Does the development office motivate faculty members to develop projects and to write proposals?

$\begin{array}{llllll}\text { VARIABLE } & \text { VALUE } & \text { F } & \% & \text { M } & \text { SD } \\ \text { Dev. Officel } & \text { Yes (1) } & 9 & 28.1 & & \\ \text { Dev. Proposal } & \text { No (2) } & 20 & 62.5 & & \\ & \text { Missing (9) } & 3 & \underline{09.4} & & \\ & & 32 & 100.0 & 1.690 & 0.471\end{array}$

Q3 Does the development office become involved in the actual writing of the proposal?

$\begin{array}{llllll}\text { YAARIABLE } & \text { VALUE } & \text { F } & \% & M & \text { SD } \\ \text { Dev. Officel } & \text { Yes (1) } & 12 & 37.5 & & \\ \text { Write Proposal } & \text { No (2) } & 17 & 53.1 & & \\ & \text { Missing (9) } & 3 & \underline{09.4} & & \\ & & 32 & 100.0 & 1.586 & 0.501\end{array}$


Q4 How important to development is it for the dean's office to identify and publicize substantive institutional activities that may be identified as important by the community or prospective contributors?

$\begin{array}{llllll}\text { VARIABLE } & \text { VALUE } & \text { F } & \% & M & \text { SD } \\ \text { Deanl } & \text { Very Unimpt (1) } & 1 & 03.1 & & \\ \text { Publicize } & \text { Gen Unimpt (2) } & 0 & 00.0 & & \\ \text { School } & \text { Gen Impt (3) } & 10 & 31.3 & & \\ & \text { Very Impt (4) } & 20 & 62.5 & & \\ & \text { Missing (9) } & 1 & 03.1 & & \\ & & 32 & 100.0 & 3.581 & 0.672\end{array}$

Q5 How effectively does your entire school communicate its case for philanthropic support?

$\begin{array}{llllll}\text { VARIABLE } & \text { VALUE } & \text { F } & \% & \text { M } & \text { SD } \\ \text { Schooll } & \text { Very Ineffct (1) } & 1 & 03.1 & & \\ \text { Communicate } & \text { Gen Ineffct (2) } & 10 & 31.3 & \\ \text { Case St. } & \text { Gen. Effct (3) } & 17 & 53.1 & & \\ & \text { Very Effct (4) } & 3 & 09.4 & & \\ & \text { Missing (9) } & 1 & \underline{03.1} & & \\ & & 32 & 100.0 & 2.710 & 0.693\end{array}$

Q6 How effective is the university's development office in aiding your school's advancement activities?

\begin{tabular}{llllll} 
VARIABLE & VALUE & $F$ & $\%$ & $M$ & SD \\
\hline Univ. Dev.l & Very Ineffct (1) & 1 & 03.1 & & \\
Aid School & Gen Ineffct (2) & 9 & 28.1 & & \\
Dev & Gen Effct (3) & 13 & 40.6 & & \\
& Very Effct (4) & 7 & 21.9 & & \\
& Missing (9) & 2 & $\underline{06.3}$ & & \\
& & 32 & 100.0 & 2.867 & 0.819
\end{tabular}


Q7 How important is the public's impression of your school (i.e., the image your institution has in the public's eye) to the development program?

\begin{tabular}{llllll} 
VAAIABLE & VALUE & F & $\%$ & M & SD \\
\hline Schooll & Very Unimpt (1) & 1 & 03.1 & & \\
Image & Gen Unimpt (2) & 1 & 03.1 & & \\
& Gen Impt (3) & 6 & 18.8 & & \\
& Very Impt (4) & 23 & 71.9 & & \\
& Missing (9) & 1 & $\underline{03.1}$ & & \\
& & 32 & 100.0 & 3.645 & 0.709
\end{tabular}

Q8 How much school time or money (i.e., emphasis) is spent on improving your school's public image?

$\begin{array}{llllll}\text { VARIABLE } & \text { VALUE } & \text { F } & \% & \text { M } & \text { SD } \\ \text { School Imagel } & \text { No Emphasis (1) } & 0 & 00.0 & & \\ \text { Time-Money } & \text { Min. Emphasis (2) } & 6 & 18.8 & & \\ & \text { Mod. Emphasis (3) } & 18 & 56.3 & & \\ & \text { Hvy Emphasis (4) } & 7 & 21.9 & & \\ & \text { Missing (9) } & 1 & 03.1 & & \\ & & 32 & 100.0 & 3.032 & 0.657\end{array}$

Q9 How much time or money (i.e., emphasis) is spent on personal visits by the dean to the school's fund raising efforts?

\begin{tabular}{llllll} 
VARIABLE & VALUE & F & $\%$ & M & SD \\
\hline Dean Visit/ & No Emphasis (1) & 0 & 00.0 & & \\
Iime-Money & Min Emphasis (2) & 6 & 18.8 & \\
& Mod. Emphasis (3) & 14 & 43.8 & & \\
& Hvy Emphasis (4) & 10 & 31.3 & & \\
& Missing (9) & 2 & $\underline{06.3}$ & & \\
& & 32 & 100.0 & 3.133 & 0.730
\end{tabular}


DEAN SURVEY

DEMOGRAPHIC INFORMATION

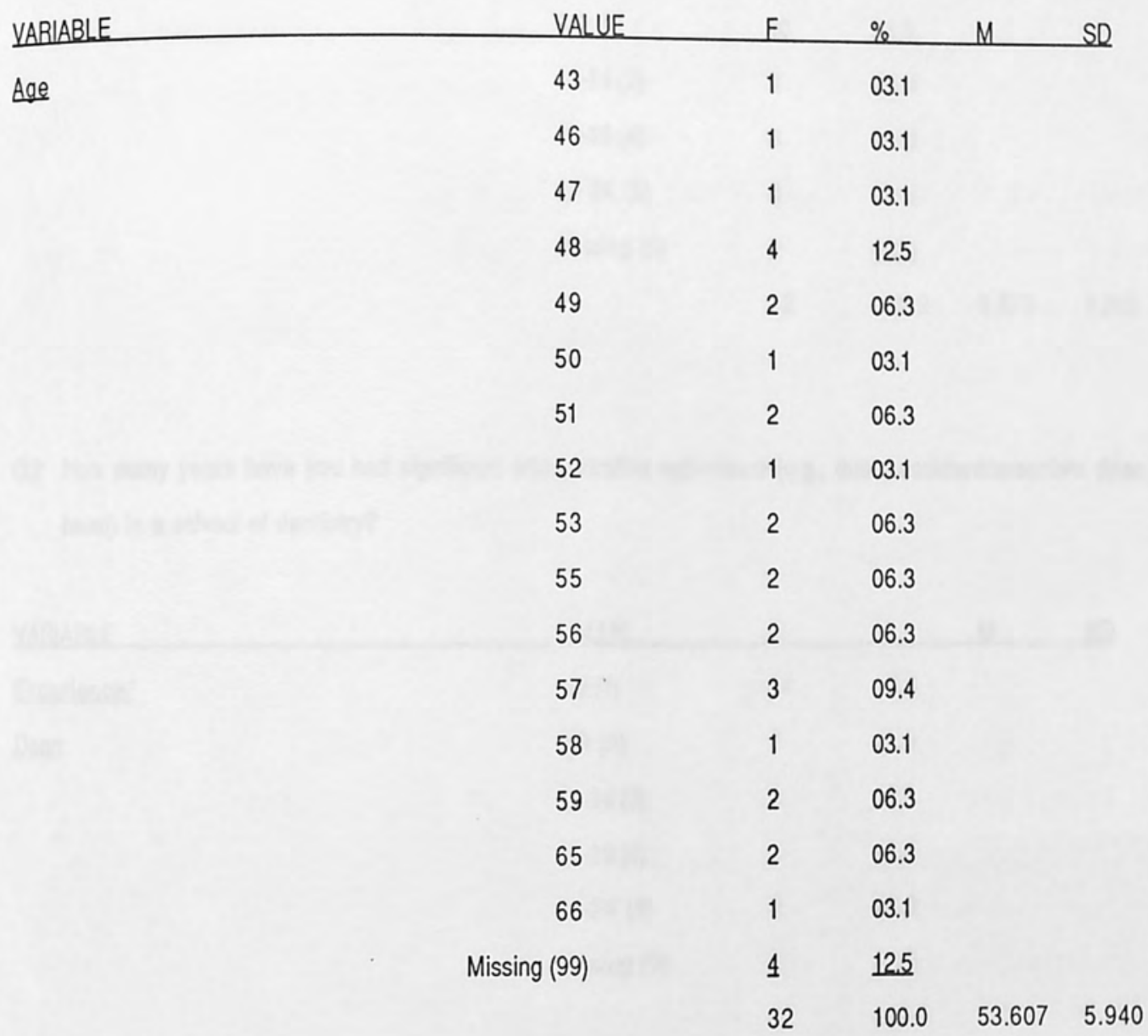

Gender

$\begin{array}{lllll}\text { Male (1) } & 30 & 93.8 & & \\ \text { Female (2) } & 0 & 00.0 & & \\ \text { Missing (9) } & 2 & \underline{06.3} & & \\ & 32 & 100.0 & 1.000 & 0.000\end{array}$

Ethnicity

$\begin{array}{lllll}\text { Caucasian (1) } & 19 & 59.4 & & \\ \text { Hispanic (2) } & 0 & 00.0 & & \\ \text { African-Am (3) } & 0 & 00.0 & & \\ \text { Asian-Pac (4) } & 0 & 00.0 & & \\ \text { Others (5) } & 0 & 00.0 & & \\ \text { Missing (9) } & 13 & 40.6 & & \\ & 32 & 100.0 & 1.000 & 0.000\end{array}$


Q1 How long have you been dean at this school?

$\begin{array}{llllll}\text { VARIABLE } & \text { VALUE } & F & \% & M & \text { SD } \\ \text { Ienure } & 1-4(1) & 16 & 50.0 & & \\ & 5-9(2) & 10 & 31.3 & & \\ 10-14(3) & 3 & 09.4 & & \\ & 15-19(4) & 0 & 00.0 & & \\ & 20-24(5) & 3 & 09.4 & & \\ \text { Missing (9) } & 0 & \underline{00.0} & & \\ & & 32 & 100.0 & 1.875 & 1.212\end{array}$

Q2 How many years have you had significant administrative experience (e.g., dean, assistant/associate dean, department head) in a school of dentistry?

$\begin{array}{llllll}\text { VARIABLE } & \text { VALUE } & F & \% & \text { M } & \text { SD } \\ \text { Experiencel } & 1-4(1) & 14 & 43.8 & & \\ \text { Dean } & 5-9(2) & 7 & 21.9 & & \\ & 10-14(3) & 4 & 12.5 & & \\ & 15-19(4) & 2 & 06.3 & & \\ & 20-24(5) & 2 & 06.3 & & \\ & \text { Missing (9) } & 3 & 09.4 & & \\ & & 32 & 100.0 & 2.000 & 1.254\end{array}$

$\begin{array}{llllll}\text { VARIABLE } & \text { VALUE } & F & \% & M & \text { SD } \\ \text { Experiencel } & 1-4(1) & 11 & 34.4 & & \\ \text { Asst.-Assoc } & 5-9(2) & 5 & 15.6 & & \\ \text { Dean } & 10-14(3) & 3 & 09.4 & & \\ & 15-19(4) & 1 & 03.1 & & \\ & 20-24(5) & 0 & 00.0 & & \\ & \text { Missing (9) } & 12 & \underline{37.5} & & \\ & & 32 & 100.0 & 1.700 & 0.923\end{array}$




$\begin{array}{llllll}\text { VARIABLE } & \text { VALUE } & F & \% & M & \text { SD } \\ \text { Experiencel } & 1-4(1) & 7 & 21.9 & & \\ \text { Dept Head } & 5-9(2) & 7 & 21.9 & & \\ & 10-14(3) & 6 & 18.8 & \\ & 15-19(4) & 3 & 09.4 & & \\ & 20-24(5) & 0 & 00.0 & & \\ & \text { Missing (9) } & 2 & 28.1 & & \\ & & 32 & 100.0 & 2.217 & 1.043\end{array}$


DEVELOPMENT OFFICER SURVEY

INSTITUTIONAL INFORMATION

\section{VARIABLE: PRE-DOCTORAL ENROLLMENT (1989-90)}

\begin{tabular}{|c|c|c|c|}
\hline Value Label & Value & Erequency & Percent \\
\hline $80-149$ & 1 & 2 & 08.0 \\
\hline $150-219$ & 2 & 1 & 04.0 \\
\hline $220-289$ & 3 & 4 & 16.0 \\
\hline $290-359$ & 4 & 8 & 32.0 \\
\hline $360-429$ & 5 & 3 & 12.0 \\
\hline $430-499$ & 6 & 1 & 04.0 \\
\hline $500-950$ & 7 & 1 & 04.0 \\
\hline (Missing) & 9 & 5 & 20.0 \\
\hline & & 25 & 100.0 \\
\hline
\end{tabular}

MEAN: 3.800

STD DEV: 1.473

VARIABLE: POST-DOCTORAL ENROLLMENT (1989-90)

\begin{tabular}{|c|c|c|c|}
\hline Value Label & Value & Erequency & Percent \\
\hline $6-24$ & 1 & 1 & 04.0 \\
\hline $25-39$ & 2 & 4 & 16.0 \\
\hline $40-54$ & 3 & 8 & 32.0 \\
\hline $55-69$ & 4 & 0 & 00.0 \\
\hline $70-84$ & 5 & 3 & 12.0 \\
\hline $85-99$ & 6 & 1 & 04.0 \\
\hline $100-195$ & 7 & 2 & 08.0 \\
\hline (Missing) & 9 & 6 & 24.0 \\
\hline & & 25 & 100.0 \\
\hline
\end{tabular}

MEAN: 3.579

STD DEV: 1.742 
VARIABLE: FACULTY / FTE (1989-90)

Value Label

25-54

$55-74$

75-94

95-114

115-134

135-185

(Missing)

Total

MEAN: 3.000

\begin{tabular}{|c|c|c|c|}
\hline & Value & Erequency & Percent \\
\hline & 1 & 4 & 16.0 \\
\hline & 2 & 5 & 20.0 \\
\hline & 3 & 2 & 08.0 \\
\hline & 4 & 4 & 16.0 \\
\hline & 5 & 0 & 00.0 \\
\hline & 6 & 3 & 12.0 \\
\hline & 9 & 1 & 28.0 \\
\hline Total & & 25 & 100.0 \\
\hline
\end{tabular}

STDDEV: 1.749

VARIABLE: FACULTY / PART-TIME (1989-90)

\begin{tabular}{|c|c|c|c|}
\hline Value Label & Value & Erequency & Percent \\
\hline $3-44$ & 1 & 5 & 20.0 \\
\hline $45-79$ & 2 & 4 & 16.0 \\
\hline $80-114$ & 3 & 2 & 08.0 \\
\hline $115-149$ & 4 & 2 & 08.0 \\
\hline $150-184$ & 5 & 3 & 12.0 \\
\hline $185-219$ & 6 & 2 & 08.0 \\
\hline $220-250$ & 7 & 0 & 00.0 \\
\hline (Missing) & 9 & 1 & 28.0 \\
\hline & & 25 & 100.0 \\
\hline
\end{tabular}


Value Label

\begin{tabular}{|c|c|c|c|}
\hline (Millions) & $\underline{\text { Value }}$ & Erequency & Percent \\
\hline $4-11$ & 1 & 3 & 12.0 \\
\hline $12-14$ & 2 & 3 & 12.0 \\
\hline $15-17$ & 3 & 3 & 12.0 \\
\hline $18-20$ & $A$ & 3 & ic.v \\
\hline $21-23$ & 5 & 1 & 04.0 \\
\hline $24-26$ & 6 & 1 & 04.0 \\
\hline $27-37$ & 7 & 1 & 04.0 \\
\hline (Missing) & 9 & 10 & 40.0 \\
\hline & & 25 & 100.0 \\
\hline
\end{tabular}

MEAN: 3.200

STD DEV: 1.821

VARIABLE: TUITION-FEES / REVENUES (FY 1989-90)

Value Label

\begin{tabular}{|c|c|c|c|}
\hline (Thousands) & Value & Erequency & Percent \\
\hline 300-3999 & 1 & 8 & 32.0 \\
\hline 4000-6999 & 2 & 5 & 20.0 \\
\hline $7000-9999$ & 3 & 1 & 04.0 \\
\hline $10000-12999$ & 4 & 2 & 08.0 \\
\hline $13000-15999$ & 5 & 0 & 00.0 \\
\hline $16000-19999$ & 6 & 1 & 04.0 \\
\hline $20000-24000$ & 7 & 0 & 00.0 \\
\hline (Missing) & 9 & $\underline{8}$ & $\underline{32.0}$ \\
\hline & & 25 & 100.0 \\
\hline
\end{tabular}

MEAN: 2.059

STDDEV: 1.435 
Value Label

Thousands)

400-1999

2000-2999

3000-3999

4000-4999

5000-5999

$6000-7000$

(Missing)

$\begin{array}{cccc} & \text { Value } & \text { Erequency } & \text { Percent } \\ 1 & 6 & 24.0 \\ 2 & 3 & 12.0 \\ 3 & 2 & 08.0 \\ 4 & 3 & 12.0 \\ 5 & 2 & 08.0 \\ \text { Total } & 6 & 1 & 04.0 \\ & 9 & 25 & 32.0 \\ & & 8 & 100.0\end{array}$

MEAN: 2.706

STD DEV: 1.687

VARIABLE: PRE-DOCTORAL ENROLLMENT (1990-91)

Value Label

80-149

150-219

220-289

290-359

$360-429$

430-499

500-950

(Missing)
Value

1

2

3

4

5

6

7

9

Total

\begin{tabular}{|c|c|}
\hline Erequency & Percent \\
\hline 1 & 04.0 \\
\hline 2 & 08.0 \\
\hline 2 & 08.0 \\
\hline 8 & 32.0 \\
\hline 2 & 08.0 \\
\hline 0 & 00.0 \\
\hline 1 & 04.0 \\
\hline 2 & 36.0 \\
\hline 25 & 100.0 \\
\hline
\end{tabular}

MEAN: 3.750

STD DEV: 1.390 
Value Label

$$
\text { 6-24 }
$$

25-39

40-54

55-69

70-84

85-99

100-195

(Missing)

Total

MEAN: 3.786

$\begin{array}{cccc} & \text { Value } & \text { Erequency } & \text { Percent } \\ 1 & 0 & 00.0 \\ 2 & 3 & 12.0 \\ 3 & 4 & 16.0 \\ 4 & 2 & 08.0 \\ & 5 & 4 & 16.0 \\ 6 & 0 & 00.0 \\ & 7 & 1 & 04.0 \\ \text { Total } & 9 & 11 & 44.0 \\ & & 25 & 100.0\end{array}$

STD DEV: 1.477

VARIABLE: FACULTY / FTE (1990-91)

Value Label

25-54

55-74

75-94

95-114

115-134

135-185

(Missing)
Total

$\begin{array}{cccc} & \text { Value } & \text { Erequency } & \text { Percent } \\ 1 & 2 & 08.0 \\ 2 & 4 & 16.0 \\ 3 & 2 & 08.0 \\ 4 & 4 & 16.0 \\ & 5 & 1 & 04.0 \\ & 6 & 2 & 08.0 \\ \text { Total } & 9 & 10 & 40.0 \\ & & 25 & 100.0\end{array}$

MEAN: 3.267

STDDEV: 1.624 


\begin{tabular}{|c|c|c|c|}
\hline Value Label & Value & Erequency & Percent \\
\hline $3-44$ & 1 & 3 & 12.0 \\
\hline $45-79$ & 2 & 4 & 16.0 \\
\hline $80-114$ & 3 & 3 & 12.0 \\
\hline $115-149$ & 4 & 2 & 08.0 \\
\hline $150-184$ & 5 & 1 & 04.0 \\
\hline $185-219$ & 6 & 2 & 08.0 \\
\hline $220-250$ & 7 & 0 & 00.0 \\
\hline (Missing) & 9 & 10 & 40.0 \\
\hline & & 25 & 100.0 \\
\hline
\end{tabular}

MEAN: 3.000

STDDEV: 1.690

VARIABLE: BUDGET (FY 1990-91)

Value Label

(Millions)

4-11

Value

Erequency

Percent

12-14

1

2

08.0

04.0

15-17

2

1

12.0

18-20

3

04.0

21-23

1

24-26

27. 37

(Missing)

4

1

08.0

04.0

04.0

56.0

Total

14

100.0 


\begin{tabular}{|c|c|c|c|}
\hline (Thousands) & Value & Erequency & Percent \\
\hline 300-3999 & 1 & 4 & 16.0 \\
\hline 4000-6999 & 2 & 2 & 08.0 \\
\hline $7000-9999$ & 3 & 2 & 08.0 \\
\hline $10000-12999$ & 4 & 1 & 04.0 \\
\hline $13000-15999$ & 5 & 0 & 00.0 \\
\hline $16000-19999$ & 6 & 0 & 00.0 \\
\hline $20000-24000$ & 7 & 1 & 04.0 \\
\hline (Missing) & 9 & 15 & 600 \\
\hline & & 25 & 100.0 \\
\hline
\end{tabular}

MEAN: 2.500

STD DEV: 1.900

\section{VARIABLE: PATIENT CARE / REVENUES (FY 1990-91)}

\begin{tabular}{|c|c|c|c|}
\hline Thousands) & Value & Erequency & Percent \\
\hline 400-1999 & 1 & 2 & 08.0 \\
\hline $2000-2999$ & 2 & 3 & 12.0 \\
\hline $3000-3999$ & 3 & 1 & 04.0 \\
\hline $4000-4999$ & 4 & 1 & 04.0 \\
\hline $5000-5999$ & 5 & 2 & 08.0 \\
\hline $6000-7000$ & 6 & 1 & 04.0 \\
\hline (Missing) & 9 & 15 & 60.0 \\
\hline & & 25 & 100.0 \\
\hline
\end{tabular}

MEAN: 3.100

STD DEV: 1.792 


\section{DEVELOPMENT OFFICER SURVEY}

\section{ORGANIZATIONAL STRUCTURE AND MANAGEMENT PRACTICES}

Q1 Does your school have a separate development office?

$\begin{array}{llllll}\text { VARIABLE } & \text { VALUE } & F & \% & M & \text { SD } \\ \text { Dev. Officel } & \text { Yes (1) } & 17 & 68.0 & & \\ \text { Separate } & \text { No (2) } & 8 & 32.0 & & \\ & \text { Missing (9) } & 0 & \underline{00.0} & & \\ & & 25 & 100.0 & 1.320 & 0.476\end{array}$

Q2 In what year was the development office organized?

$\begin{array}{llllll}\text { VARIABLE } & \text { VALUE } & F & \% & M & \text { SD } \\ \text { Dev. Officel } & 1960-64(1) & 0 & 00.0 & \\ \text { Yr. Organized } & 1965-69(2) & 1 & 4.0 & \\ & 1970-74(3) & 4 & 16.0 & \\ & 1975-79(4) & 8 & 32.0 & \\ & 1980-84(5) & 1 & 04.0 & \\ & 1985-90(6) & 6 & 24.0 & \\ & \text { Missing (9) } & 5 & 20.0 & & \\ & & 25 & 100.0 & 4.350 & 1.268\end{array}$

Q3 What is the title of the school development officer?

$\begin{array}{llllll}\text { VARIABLE } & \text { VALUE } & F & \% & M & \text { SD } \\ \text { Dev, Officerl } & \text { Dir. Dev. (1) } & 15 & 60.0 & & \\ \text { Iitle } & \text { Other (2) } & 9 & 36.0 & & \\ & \text { Missing (9) } & 1 & \underline{04.0} & & \\ & & 25 & 100.0 & 1.375 & 0.495\end{array}$


Q4 To what administrative officer does he or she report?

$\begin{array}{llllll}\text { VARIABLE } & \text { VALUE } & F & \% & M & \text { SD } \\ \text { Dev. Officerl } & \text { Dean (1) } & 11 & 44.0 & & \\ \text { Reperts to } & \text { Dean/Univ (2) } & 5 & 20.0 & \\ & \text { Univ Dev. (3) } & 4 & 16.0 & \\ & \text { Univ Adm (4) } & 2 & 08.0 & & \\ & \text { Other (5) } & 3 & 12.0 & & \\ & \text { Missing (9) } & 0 & \underline{00.0} & & \\ & & 25 & 100.0 & 2.240 & 1.422\end{array}$

Q5 How many professional and support staff does the school's development office have?

$\begin{array}{llllll}\text { VARIABLE } & \text { VALUE } & F & \% & M & \text { SD } \\ \text { Dev. Officel } & 1-2(1) & 19 & 76.0 & & \\ \text { Staff } & 3-4(2) & 1 & 04.0 & & \\ & 5-6(3) & 1 & 04.0 & & \\ & 7-10(4) & 1 & 04.0 & & \\ & \text { Missing (9) } & 3 & 12.0 & & \\ & & 25 & 100.0 & 1.273 & 0.767\end{array}$

Q 6 How many years experience does the school development officer have as a development professional?

$\begin{array}{llllll}\text { VARIABLE } & \text { VALUE } & F & \% & M & \text { SD } \\ \text { Dev. Officerl } & 1-4(1) & 6 & 24.0 & & \\ \text { Yrs. Experience } & 5-9(2) & 8 & 32.0 & & \\ & 10-14(3) & 7 & 28.0 & & \\ & 15-20(4) & 3 & 12.0 & & \\ & \text { Missing (9) } & 1 & \underline{04.0} & & \\ & & 25 & 100.0 & 2.292 & 0.999\end{array}$


Q7 How long has the school development officer been in his/her current post at the school?

$\begin{array}{llllll}\text { VABIABLE } & \text { VALUE } & F & \% & M & \text { SD } \\ \text { Dev. Officerl } & 1-4(1) & 20 & 80.0 & & \\ \text { Ienure } & 5-9(2) & 4 & 16.0 & & \\ & 10-14(3) & 0 & 00.0 & & \\ & 15-20(4) & 1 & 04.0 & & \\ & \text { Missing (9) } & 0 & \underline{0.0} & & \\ & & 25 & 100.0 & 1.280 & 0.678\end{array}$

Q8 Does the school have a formal case statement (published development document) which outlines the goals of the school, the purpose of raising private voluntary support, and describes how private support will be utilized by the school?

\begin{tabular}{llllll} 
VAAIABLE & VALUE & $F$ & $\%$ & $M$ & SD \\
\hline Schooll & Yes (1) & 10 & 40.0 & & \\
Case S. & No (2) & 15 & 60.0 & & \\
& Missing (9) & 0 & $\underline{00.0}$ & & \\
& & 25 & 100.0 & 1.600 & 0.500
\end{tabular}

Q9 How involved is each of the following in the development of the school's case statement?

$\begin{array}{llllll}\text { VARIABLE } & \text { VALUE } & F & \% & M & \text { SD } \\ \text { Dean/ } & \text { Very Uninvol (1) } & 1 & 04.0 & & \\ \text { Case St. } & \text { Gen Uninvol (2) } & 0 & 00.0 & \\ & \text { Gen Invol (3) } & 4 & 16.0 & & \\ & \text { Very Invol. (4) } & 13 & 52.0 & & \\ & \text { Missing (9) } & Z & \underline{28.0} & & \\ & & 25 & 100.0 & 3.611 & 0.778\end{array}$




$\begin{array}{llllll}\text { VARIABLE } & \text { VALUE } & F & \% & M & \text { SD } \\ \text { Dev. Officerl } & \text { Very Uninvol (1) } & 1 & 04.0 & & \\ \text { Case St. } & \text { Gen Uninvol (2) } & 0 & 00.0 & & \\ & \text { Gen Invol (3) } & 2 & 08.0 & & \\ & \text { Very Invol (4) } & 15 & 60.0 & & \\ & \text { Missing (9) } & I & 28.0 & & \\ & & 25 & 100.0 & 3.722 & 0.752\end{array}$

Univ.l

Case St.

$\begin{array}{lllll}\text { Very Uninvol (1) } & 0 & 00.0 & & \\ \text { Gen Uninvol (2) } & 5 & 20.0 & & \\ \text { Gen Invol (3) } & 9 & 36.0 & & \\ \text { Very Invol (4) } & 4 & 16.0 & & \\ \text { Missing (9) } & \text { I } & \underline{28.0} & & \\ & 25 & 100.0 & 2.944 & 0.725\end{array}$

Q10 Is a written annual development plan, with projected goals, prepared and presented for approval?

$\begin{array}{llllll}\text { VARIABLE } & \text { VALUE } & F & \% & M & \text { SD } \\ \text { Annual } & \text { Yes (1) } & 19 & 76.0 & & \\ \text { Dev.Plan } & \text { No (2) } & 6 & 24.0 & & \\ & \text { Missing (9) } & 0 & \underline{000} & & \\ & & 25 & 100.0 & 1.240 & 0.436\end{array}$

Q11 How involved is each of the following in evaluating the school's fund raising program?

\begin{tabular}{llllll} 
VARIABLE & VALUE & $F$ & $\%$ & $M$ & SD \\
\hline Deanl & Very Uninvol (1) & 1 & 04.0 & & \\
Eval Fund & Gen Uninvol (2) & 3 & 12.0 & & \\
Baising & Gen Invol (3) & 8 & 32.0 & & \\
& Very Invol (4) & 13 & 52.0 & & \\
& Missing (9) & 0 & $\underline{00.0}$ & & \\
& & 25 & 100.0 & 3.320 & 0.852
\end{tabular}




$\begin{array}{llllll}\text { VARIABLE } & \text { VALUE } & F & \% & M & \text { SD } \\ \text { Dev. Officerl } & \text { Very Uninvol (1) } & 1 & 04.0 & & \\ \text { Eval Fund } & \text { Gen Uninvol (2) } & 0 & 00.0 & \\ \text { Baising } & \text { Gen Invol (3) } & 4 & 16.0 & \\ & \text { Very Invol (4) } & 20 & 80.0 & & \\ & \text { Missing (9) } & 0 & \underline{00.0} & & \\ & & 25 & 100.0 & 3.720 & 0.678 \\ & & & & & \\ \text { Univ.l } & \text { Very Uninvol (1) } & 0 & 00.0 & & \\ \text { Eval Fund } & \text { Gen Uninvol (2) } & 1 & 04.0 & & \\ \text { Baising } & \text { Gen Invol (3) } & 13 & 52.0 & & \\ & \text { Very Invol (4) } & 11 & 44.0 & & \\ & \text { Missing (9) } & 0 & \underline{0.0} & & \\ & & 25 & 100.0 & 3.400 & 0.577\end{array}$

Q12 Please identify the importance of the following criteria in evaluating the school's fund raising program.

$\begin{array}{llllll}\text { VARIABLE } & \text { VALUE } & F & \% & M & \text { SD } \\ \text { Iotal Funds } & \text { Very Unimpt (1) } & 1 & 04.0 & & \\ \text { Baised } & \text { Gen Unimpt (2) } & 0 & 00.0 & \\ & \text { Gen Impt (3) } & 8 & 32.0 & \\ & \text { Very Impt (4) } & 15 & 60.0 & & \\ & \text { Missing (9) } & 1 & \underline{04.0} & & \\ & & 25 & 100.0 & 3.542 & 0.721 \\ \text { Percent } & & & & & \\ \text { lncrease in } & \text { Very Unimpt (1) } & 1 & 04.0 & & \\ \text { Eunds } & \text { Gen Unimpt (2) } & 1 & 04.0 & & \\ & \text { Gen Impt (3) } & 9 & 36.0 & & \\ & \text { Very Impt (4) } & 13 & 52.0 & & \\ & \text { Missing (9) } & 1 & \underline{04.0} & & \\ & & 25 & 100.0 & 3.417 & 0.776\end{array}$




$\begin{array}{llllll}\text { VARIABLE } & \text { VALUE } & F & \% & \text { SD } \\ \text { Number of } & \text { Very Unimpt (1) } & 0 & 00.0 & \\ \text { Contributers } & \text { Gen Unimpt (2) } & 2 & 08.0 & \\ & \text { Gen Impt (3) } & 8 & 32.0 & \\ & \text { Very Impt (4) } & 14 & 56.0 & & \\ & \text { Missing (9) } & 1 & \underline{04.0} & & \\ & & 25 & 100.0 & 3.500 & 0.659 \\ \text { Number of } & & & & & \\ \text { Volunteer } & \text { Very Unimpt (1) } & 0 & 00.0 & & \\ \text { Workers } & \text { Gen Unimpt (2) } & 11 & 44.0 & & \\ & \text { Gen Impt (3) } & 9 & 36.0 & & \\ & \text { Very Impt (4) } & 4 & 16.0 & & \\ & \text { Missing (9) } & 1 & \underline{04.0} & & \\ & & 25 & 100.0 & 2.708 & 0.751\end{array}$

Q 13 Is an annual report prepared?

$\begin{array}{llllll}\text { VARIABLE } & \text { VALUE } & F & \% & M & \text { SD } \\ \text { Annual } & \text { Yes (1) } & 17 & 68.0 & & \\ \text { Beport } & \text { No (2) } & 8 & 32.0 & & \\ & \text { Missing (9) } & 0 & \underline{00.0} & & \\ & & 25 & 100.0 & 1.320 & 0.476\end{array}$




\section{DEVELOPMENT OFFICER SURVEY}

\section{FUND RAISING SOURCES, CONSTITUENCIES, AND RECORD KEEPING}

Q1 How effective are the following constituencies in providing funds to support your school?

\section{VARIABLE}

Supporty

Alumni

Supporty

Nen-Alumni

Supporty

Business

Industry

$\begin{array}{lllll}\text { VALUE } & \text { F } & \% & \text { M } & \text { SD } \\ \text { Very Ineffct (1) } & 0 & 00.0 & & \\ \text { Gen Ineffct (2) } & 4 & 16.0 & & \\ \text { Gen Effct (3) } & 13 & 52.0 & & \\ \text { Very Effct (4) } & 8 & 32.0 & & \\ \text { Missing (9) } & \mathbb{Q} & \underline{00.0} & & \\ & 25 & 100.0 & 3.160 & 0.688\end{array}$

$\begin{array}{lllll}\text { Very Ineffct (1) } & 1 & 04.0 & & \\ \text { Gen Ineffct (2) } & 11 & 44.0 & & \\ \text { Gen Effct (3) } & 10 & 40.0 & & \\ \text { Very Effct (4) } & 3 & 12.0 & & \\ \text { Missing (9) } & \ell & \underline{00.0} & & \\ & 25 & 100.0 & 2.600 & 0.764\end{array}$

$\begin{array}{llllll}\text { Very Ineffct (1) } & 4 & 16.0 & & \\ \text { Gen Ineffct (2) } & 12 & 48.0 & & \\ \text { Gen Effct (3) } & 8 & 32.0 & & \\ \text { Very Effct (4) } & 1 & 04.0 & & \\ \text { Missing (9) } & 0 & \underline{00.0} & & \\ & 25 & 100.0 & 2.240 & 0.779\end{array}$

Support/

Very Ineffct (1) $\quad 5 \quad 20.0$

Private

Gen Ineffct (2) $\quad 10 \quad 40.0$

Eoundations

$\begin{array}{lllll}\text { Gen Effct (3) } & 7 & 28.0 & & \\ \text { Very Effct (4) } & 2 & 08.0 & & \\ \text { Missing (9) } & 1 & \underline{04.0} & & \\ & 25 & 100.0 & 2.250 & 0.897\end{array}$




$\begin{array}{llllll}\text { VARIABLE } & \text { VALUE } & F & \% & M & \text { SD } \\ \text { Supportl } & \text { Very Ineffct (1) } & 7 & 28.0 & & \\ \text { Clubs } & \text { Gen Ineffct (2) } & 11 & 44.0 & & \\ \text { Organizations } & \text { Gen Effct (3) } & 4 & 16.0 & & \\ & \text { Very Effct (4) } & 1 & 04.0 & & \\ & \text { Missing (9) } & 2 & \underline{08.0} & & \\ & & 25 & 100.0 & 1.957 & 0.825\end{array}$

Q2 How much development time or money (i.e., emphasis) is spent by the development office in seeking funds from the following sources?

VARIABLE

Major Gift

Programs

Annual

Eund

Deferred

(Planned) Gifts

$\begin{array}{lllll}\text { VALUE } & F & \% & M & \text { SD } \\ \text { No Emphasis (1) } & 1 & 04.0 & & \\ \text { Min Emphasis (2) } & 4 & 16.0 & & \\ \text { Mod Emphasis (3) } & 8 & 32.0 & & \\ \text { Hvy Emphasis (4) } & 11 & 44.0 & & \\ \text { Missing (9) } & 1 & \underline{04.0} & & \\ & 25 & 100.0 & 3.208 & 0.884\end{array}$

$\begin{array}{lllll}\text { No Emphasis (1) } & 1 & 04.0 & & \\ \text { Min Emphasis (2) } & 1 & 04.0 & & \\ \text { Mod Emphasis (3) } & 6 & 24.0 & & \\ \text { Hvy Emphasis (4) } & 17 & 68.0 & & \\ \text { Missing (9) } & \ell & \underline{00.0} & & \\ & 25 & 100.0 & 3.560 & 0.768\end{array}$

No Emphasis (1) $3 \quad 12.0$

Min Emphasis (2) $9 \quad 36.0$

Mod Emphasis (3) $10 \quad 40.0$

Hvy Emphasis (4) $3 \quad 12.0$

Missing (9) $\quad 2 \quad \underline{00.0}$

$\begin{array}{llll}25 & 100.0 & 2.520 & 0.872\end{array}$ 
VARIABLE

Capitel

Projects

Alumni

Nen-Alumni

Friends

Business

and Industry

Clubs and

Organizations

$\begin{array}{lllll}\text { VALUE } & F & \% & M & \text { SD } \\ \text { No Emphasis (1) } & 4 & 16.0 & & \\ \text { Min Emphasis (2) } & 10 & 40.0 & & \\ \text { Mod Emphasis (3) } & 4 & 16.0 & & \\ \text { Hvy Emphasis (4) } & 6 & 24.0 & & \\ \text { Missing (9) } & 1 & \underline{04.0} & & \\ & 25 & 100.0 & 2.500 & 1.063\end{array}$

No Emphasis (1) $1 \quad 04.0$

Min Emphasis (2) $\quad 1 \quad 04.0$

Mod Emphasis (3) $1 \quad 04.0$

Hvy Emphasis (4) $22 \quad 88.0$

Missing (9) $0 \quad \underline{00.0}$

$\begin{array}{llll}25 & 100.0 & 3.760 & 0.723\end{array}$

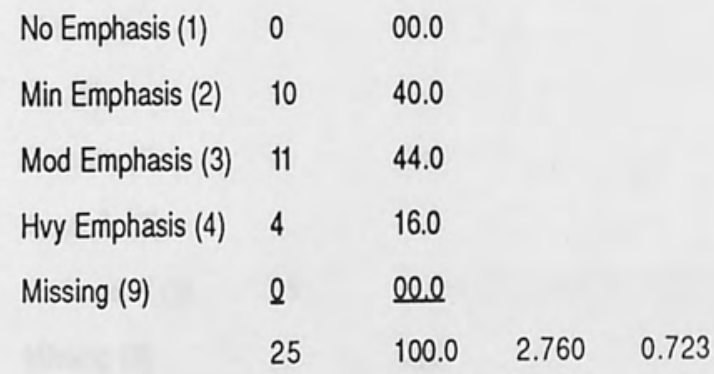

$\begin{array}{lllll}\text { No Emphasis (1) } & 4 & 16.0 \\ \text { Min Emphasis (2) } & 8 & 32.0 & \\ \text { Mod Emphasis (3) } & 9 & 36.0 & \\ \text { Hvy Emphasis (4) } & 4 & 16.0 & & \\ \text { Missing (9) } & \text { Q } & \underline{00.0} & & \\ & 25 & 100.0 & 2.520 & 0.963\end{array}$

$\begin{array}{lllll}\text { No Emphasis (1) } & 9 & 36.0 & \\ \text { Min Emphasis (2) } & 9 & 36.0 & \\ \text { Mod Emphasis (3) } & 4 & 16.0 & & \\ \text { Hvy Emphasis (4) } & 2 & 08.0 & & \\ \text { Missing (9) } & 1 & \underline{04.0} & & \\ & 25 & 100.0 & 1.958 & 0.955\end{array}$


Q3 How many records (i.e., total number of all names on mailing lists) are stored?

$\begin{array}{llllll}\text { VARIABLE } & \text { VALUE } & F & \% & M & \text { SD } \\ \text { Becords/ } & 1-4999(1) & 8 & 32.0 & & \\ \text { Number } & 5000-9999(2) & 12 & 48.0 & & \\ & 10000-19999(3) & 2 & 08.0 & & \\ & 20000-50000(4) & 3 & 12.0 & & \\ & \text { Missing (9) } & \ell & \underline{0.0} & & \\ & & 25 & 100.0 & 2.000 & 0.957\end{array}$

Q4 How often is an analysis of prior giving by individual and/or other constituencies done?

$\begin{array}{llllll}\text { VARIABLE } & \text { VALUE } & F & \% & M & \text { SD } \\ \text { Records/ } & \text { Monthly (1) } & 2 & 08.0 & \\ \text { Updated } & \text { Bi-Mo (2) } & 0 & 00.0 & \\ & \text { Qtr (3) } & 0 & 00.0 & \\ & \text { Semi-An (4) } & 0 & 00.0 & \\ & \text { Annually (5) } & 4 & 16.0 & \\ & \text { As Needed (6) } & 19 & 76.0 & & \\ & \text { Missing (9) } & 0 & \underline{00.0} & & \\ & & 25 & 100.0 & 5.440 & 1.387\end{array}$




\section{DEVELOPMENT OFFICER SURVEY}

\section{EUND RAISING METHODS AND TECHNIQUES}

Q1 How involved is the dean in the following advancement activities?

$\begin{array}{llllll}\text { VARIABLE } & \text { VALUE } & F & \% & M & \text { SD } \\ \text { Providing } & \text { Very Uninvol (1) } & 0 & 00.0 & & \\ \text { Leadership } & \text { Gen Uninvol (2) } & 3 & 12.0 & & \\ & \text { Gen Invol (3) } & 7 & 28.0 & & \\ & \text { Very Invol (4) } & 15 & 60.0 & & \\ & \text { Missing (9) } & 0 & \underline{00.0} & & \\ & & 25 & 100.0 & 3.480 & 0.714\end{array}$

Seeking

$\begin{array}{llllll}\text { Very Uninvol (1) } & 0 & 00.0 & & \\ \text { Gen Uninvol (2) } & 7 & 28.0 & & \\ \text { Gen Invol (3) } & 11 & 44.0 & & \\ \text { Very Invol (4) } & 6 & 24.0 & & \\ \text { Missing (9) } & 1 & \underline{04.0} & & \\ & 25 & 100.0 & 2.958 & 0.751\end{array}$

Soliciting

Very Uninvol (1) $3 \quad 12.0$

Major

Gen Uninvol (2) $\quad 8 \quad 32.0$

Denor

Gen Invol (3) $\quad 6 \quad 24.0$

Very Invol (4) $\quad 8 \quad 32.0$

Missing (9) $\quad 0 \quad \underline{00.0}$

$\begin{array}{llll}25 & 100.0 & 2.760 & 1.052\end{array}$

Soliciting

Very Uninvol (1) $3 \quad 12.0$

Donor

Gen Uninvol (2) $\quad 5 \quad 20.0$

Gen Invol (3) $\quad 11 \quad 44.0$

Very Invol (4) $\quad 5 \quad 20.0$

Missing (9) $1 \quad 04.0$

$\begin{array}{llll}25 & 100.0 & 2.750 & 0.944\end{array}$ 


$\begin{array}{llllll}\text { VAABABLE } & \text { VALUE } & F & \% & M & \text { SD } \\ \text { Evaluating } & \text { Very Uninvol (1) } & 1 & 04.0 & & \\ \text { Dev. Programs } & \text { Gen Uninvol (2) } & 9 & 36.0 & \\ & \text { Gen Invol (3) } & 8 & 32.0 & \\ & \text { Very Invol (4) } & 7 & 28.0 & & \\ & \text { Missing (9) } & 0 & \underline{00.0} & & \\ & & 25 & 100.0 & 2.840 & 0.898 \\ \text { Establishing } & & & & & \\ \text { Dev. Policy } & \text { Very Uninvol (1) } & 7 & 28.0 & & \\ & \text { Gen Uninvol (2) } & 6 & 24.0 & & \\ & \text { Gen Invol (3) } & 6 & 24.0 & & \\ & \text { Very Invol (4) } & 6 & 24.0 & & \\ & \text { Missing (9) } & 0 & \underline{00.0} & & \\ & & 25 & 100.0 & 2.440 & 1.158\end{array}$

Q2 How involved are all or most members of the alumni support groups in the following advancement activities?

$\begin{array}{llllll}\text { VARIABLE } & \text { VALUE } & F & \% & M & \text { SD } \\ \text { Providing } & \text { Very Uninvol (1) } & 2 & 08.0 & & \\ \text { Leadership } & \text { Gen Uninvol (2) } & 5 & 20.0 & \\ & \text { Gen Invol (3) } & 11 & 44.0 & \\ & \text { Very Invol (4) } & 7 & 28.0 & & \\ & \text { Missing (9) } & 0 & \underline{00.0} & & \\ & & 25 & 100.0 & 2.920 & 0.909\end{array}$

$\begin{array}{llllll}\text { Seeking } & \text { Very Uninvol (1) } & 1 & 04.0 & & \\ \text { Einancial } & \text { Gen Uninvol (2) } & 7 & 28.0 & \\ \text { Support } & \text { Gen Invol (3) } & 15 & 60.0 & & \\ & \text { Very Invol (4) } & 2 & 08.0 & & \\ & \text { Missing (9) } & 0 & \underline{00.0} & & \\ & & 25 & 100.0 & 2.720 & 0.678\end{array}$




\begin{tabular}{llllll} 
VARIABLE & VALUE & $F$ & $\%$ & $M$ & SD \\
\hline Soliciting & Very Uninvol (1) & 3 & 12.0 & & \\
Major & Gen Uninvol (2) & 13 & 52.0 & & \\
Denor & Gen Invol (3) & 8 & 32.0 & & \\
& Very Invol (4) & 1 & 04.0 & & \\
& Missing (9) & 0 & $\underline{00.0}$ & & \\
& & 25 & 100.0 & 2.280 & 0.737
\end{tabular}

Soliciting

Denor

$\begin{array}{lllll}\text { Very Uninvol (1) } & 3 & 12.0 & & \\ \text { Gen Uninvol (2) } & 10 & 40.0 & & \\ \text { Gen Invol (3) } & 10 & 40.0 & & \\ \text { Very Invol (4) } & 2 & 08.0 & & \\ \text { Missing (9) } & \text { Q } & \underline{00.0} & & \\ & 25 & 100.0 & 2.440 & 0.821\end{array}$

Evaluating

Dev. Programs

$\begin{array}{lllll}\text { Very Uninvol (1) } & 7 & 28.0 & & \\ \text { Gen Uninvol (2) } & 12 & 48.0 & & \\ \text { Gen Invol (3) } & 3 & 12.0 & & \\ \text { Very Invol (4) } & 3 & 12.0 & & \\ \text { Missing (9) } & 0 & \underline{00.0} & & \\ & 25 & 100.0 & 2.080 & 0.954\end{array}$

Establishing

Very Uninvol (1) $\quad 7 \quad 28.0$

Gen Uninvol (2) $\quad 12 \quad 48.0$

Gen Invol (3) $\quad 5 \quad 20.0$

Very Invol (4) $\quad 1 \quad 04.0$

Missing (9) $\quad 2 \quad 00.0$

$\begin{array}{llll}25 & 100.0 & 2.000 & 0.816\end{array}$ 
Q3 How involved in the following school advancement activities is the university development office?

$\begin{array}{llllll}\text { VARIABLE } & \text { VALUE } & F & \% & M & \text { SD } \\ \text { Providing } & \text { Very Uninvol (1) } & 0 & 00.0 & & \\ \text { Leadership } & \text { Gen Uninvol (2) } & 3 & 12.0 & & \\ & \text { Gen Invol (3) } & 11 & 44.0 & & \\ & \text { Very Invol (4) } & 10 & 40.0 & & \\ & \text { Missing (9) } & 1 & \underline{04.0} & & \\ & & 25 & 100.0 & 3.292 & 0.690\end{array}$

Seeking

$\begin{array}{llllll}\text { Very Uninvol (1) } & 1 & 04.0 & & \\ \text { Gen Uninvol (2) } & 4 & 16.0 & & \\ \text { Gen Invol (3) } & 10 & 40.0 & & \\ \text { Very Invol (4) } & 9 & 36.0 & & \\ \text { Missing (9) } & 1 & \underline{04.0} & & \\ & 25 & 100.0 & 3.125 & 0.850\end{array}$

Soliciting

Very Uninvol (1) $1 \quad 04.0$

Major

Gen Uninvol (2) $\quad 5 \quad 20.0$

Denor

Gen Invol (3) $\quad 9 \quad 36.0$

Very Invol (4) $\quad 9 \quad 36.0$

Missing (9) $\quad 1 \quad \underline{04.0}$

$25 \quad 100.0 \quad 3.083 \quad 0.881$

Soliciting

Very Uninvol (1) $2 \quad 08.0$

Donor

Gen Uninvol (2) $\quad 4 \quad 16.0$

Gen Invol (3) $\quad 8 \quad 32.0$

Very Invol (4) $\quad 10 \quad 40.0$

Missing (9) $1 \quad \underline{04.0}$

$\begin{array}{llll}25 & 100.0 & 3.083 & 0.974\end{array}$ 


$\begin{array}{llllll}\text { VARIABLE } & \text { VALUE } & F & \% & M & \text { SD } \\ \text { Evaluating } & \text { Very Uninvol (1) } & 1 & 04.0 & & \\ \text { Dev. Programs } & \text { Gen Uninvol (2) } & 2 & 08.0 & \\ & \text { Gen Invol (3) } & 7 & 28.0 & \\ & \text { Very Invol (4) } & 14 & 56.0 & & \\ & \text { Missing (9) } & 1 & 04.0 & & \\ & & 25 & 100.0 & 3.417 & 0.830\end{array}$

Establishing

$\begin{array}{llllll}\text { Very Uninvol (1) } & 1 & 04.0 & & \\ \text { Gen Uninvol (2) } & 2 & 08.0 & & \\ \text { Gen Invol (3) } & 9 & 36.0 & & \\ \text { Very Invol (4) } & 12 & 48.0 & & \\ \text { Missing (9) } & 1 & \underline{04.0} & & \\ & 25 & 100.0 & 3.333 & 0.816\end{array}$

Q4 How important is it that the relationship between the school's development office and the university's development office be coordinated organizationally in order to enhance fund raising potential?

$\begin{array}{llllll}\text { VARIABLE } & \text { VALUE } & F & \% & M & \text { SD } \\ \text { Relationship: } & \text { Very Unimpt (1) } & 0 & 00.0 & & \\ \text { School Dev.I } & \text { Gen Unimpt (2) } & 3 & 12.0 & \\ \text { Univ. Dev. } & \text { Gen Impt (3) } & 5 & 20.0 & & \\ & \text { Very Impt (4) } & 15 & 60.0 & & \\ & \text { Missing (9) } & 2 & \underline{08.0} & & \\ & & 25 & 100.0 & 3.522 & 0.730\end{array}$

Q5 At your school, how effective is the coordination mentioned above in Q4?

$\begin{array}{llllll}\text { VARIABLE } & \text { VALUE } & F & \% & M & \text { SD } \\ \text { Coordination/ } & \text { Very Ineffct (1) } & 0 & 00.0 & & \\ \text { Belationship } & \text { Gen Ineffct (2) } & 3 & 12.0 & & \\ & \text { Gen Effct (3) } & 13 & 52.0 & & \\ & \text { Very Effct (4) } & 6 & 24.0 & & \\ & \text { Missing (9) } & 3 & 12.0 & & \\ & & 25 & 100.0 & 3.136 & 0.640\end{array}$


Q6 How effective has the dean's office been in clearly communicating the role of the development office to the entire school community and, most important, fund raising constituencies?

$\begin{array}{llllll}\text { VARIABLE } & \text { VALUE } & F & \% & M & \text { SD } \\ \text { Deanl } & \text { Very Ineffct (1) } & 1 & 04.0 & & \\ \text { Bele of Dev } & \text { Gen Ineffct (2) } & 7 & 28.0 & & \\ & \text { Gen Effct (3) } & 8 & 32.0 & & \\ & \text { Very Effct (4) } & 9 & 36.0 & & \\ & \text { Missing (9) } & \underline{0} & \underline{000} & & \\ & & 25 & 100.0 & 3.000 & 0.913\end{array}$

Q7 How important to development is it for the dean's office to help plan and coordinate fund raising campaigns?

$\begin{array}{llllll}\text { VARIABLE } & \text { VALUE } & F & \% & M & \text { SD } \\ \text { Deanl } & \text { Very Unimpt (1) } & 0 & 00.0 & & \\ \text { Plan Dev } & \text { Gen Unimpt (2) } & 1 & 04.0 & \\ \text { Campaigns } & \text { Gen Impt (3) } & 10 & 40.0 & \\ & \text { Very Impt (4) } & 14 & 56.0 & & \\ & \text { Missing (9) } & \ell & \underline{00.0} & & \\ & & 25 & 100.0 & 3.520 & 0.586\end{array}$

Q8 As an assist to the development office, how active has the dean's office been in identifying and publicizing substantive institutional activities that may be considered important by the community or prospective contributors?

$\begin{array}{llllll}\text { VARIABLE } & \text { VALUE } & F & \% & M & \text { SD } \\ \text { Deanl } & \text { Very inactive (1) } & 1 & 04.0 & & \\ \text { Assist } & \text { Gen Inactive (2) } & 4 & 16.0 & \\ \text { Dev, Office } & \text { Gen Active (3) } & 9 & 36.0 & & \\ & \text { Very Active (4) } & 10 & 40.0 & & \\ & \text { Missing (9) } & 1 & \underline{04.0} & & \\ & & 25 & 100.0 & 3.167 & 0.868\end{array}$


Q9 How much development program time or money (i.e., emphasis) is spent on improving your school's image?

$\begin{array}{llllll}\text { VAAIABLE } & \text { VALUE } & \text { F } & \% & M & \text { SD } \\ \text { School } & \text { No Emphasis (1) } & 1 & 04.0 & & \\ \text { Image } & \text { Min Emphasis (2) } & 7 & 28.0 & & \\ & \text { Mod Emphasis (3) } & 12 & 48.0 & & \\ & \text { Hvy Emphasis (4) } & 5 & 20.0 & & \\ & \text { Missing (9) } & 0 & \underline{00.0} & & \\ & & 25 & 100.0 & 2.840 & 0.800\end{array}$

Q10 How effective is the school's on-going potential donor identification (i.e., prospect research) process or system?

$\begin{array}{llllll}\text { VARIABLE } & \text { VALUE } & F & \% & M & \text { SD } \\ \text { Donor } & \text { Very Ineffct (1) } & 1 & 04.0 & & \\ \text { DP Process } & \text { Gen Ineffct (2) } & 8 & 32.0 & & \\ & \text { Gen Effct (3) } & 12 & 48.0 & & \\ & \text { Very Effct (4) } & 4 & 16.0 & & \\ & \text { Missing (9) } & \underline{0} & \underline{00.0} & & \\ & & 25 & 100.0 & 2.760 & 0.779\end{array}$

Q11 How much time or money (i.e., emphasis) is spent on prospect research and potential donor identification?

$\begin{array}{llllll}\text { VARIABLE } & \text { VALUE } & F & \% & M & \text { SD } \\ \text { Prospect } & \text { No Emphasis (1) } & 0 & 00.0 & \\ \text { Besearch } & \text { Min Emphasis (2) } & 12 & 48.0 & \\ & \text { Mod Emphasis (3) } & 7 & 28.0 & \\ & \text { Hvy Emphasis (4) } & 6 & 24.0 & & \\ & \text { Missing (9) } & \ell & \underline{0.0} & & \\ & & 25 & 100.0 & 2.760 & 0.831\end{array}$


Q12 How important are personal visits to the school's fund raising efforts?

$\begin{array}{llllll}\text { VAAIABLE } & \text { VALUE } & F & \% & M & \text { SD } \\ \text { Personal } & \text { Very Unimpt(1) } & 0 & 00.0 & & \\ \text { Visits } & \text { Gen Unimpt (2) } & 1 & 04.0 & & \\ & \text { Gen Impt (3) } & 3 & 12.0 & & \\ & \text { Very Impt (4) } & 21 & 84.0 & & \\ & \text { Missing (9) } & 0 & \underline{00.0} & & \\ & & 25 & 100.0 & 3.800 & 0.500\end{array}$

Q13 How much time or money (i.e.emphasis) is spent on personal visits by the development officer?

$\begin{array}{llllll}\text { VARIABLE } & \text { VALUE } & F & \% & M & \text { SD } \\ \text { Personal } & \text { No Emphasis (1) } & 0 & 00.0 & \\ \text { Visits } & \text { Min Emphasis (2) } & 5 & 20.0 & \\ & \text { Mod Emphasis (3) } & 10 & 40.0 & \\ & \text { Hvy Emphasis (4) } & 10 & 40.0 & & \\ & \text { Missing (9) } & 0 & \underline{00.0} & & \\ & & 25 & 100.0 & 3.200 & 0.764\end{array}$

Q14 How important is it that the development office establish the following types of fund raising goals?

$\begin{array}{llllll}\text { VARIABLE } & \text { VALUE } & \text { F } & \% & \text { M } & \text { SD } \\ \text { Higher Than } & \text { Very Unimpt (1) } & 0 & 00.0 & & \\ \text { Previous } & \text { Gen Unimpt (2) } & 1 & 04.0 & & \\ \text { Years Goal } & \text { Gen Impt (3) } & 8 & 32.0 & & \\ & \text { Very Impt (4) } & 16 & 64.0 & & \\ & \text { Missing (9) } & \ell & \underline{00.0} & & \\ & & 25 & 100.0 & 3.600 & 0.577\end{array}$




$\begin{array}{llllll}\text { VARIABLE } & \text { VALUE } & F & \% & M & \text { SD } \\ \text { Significantly } & \text { Very Unimpt (1) } & 1 & 04.0 & \\ \text { Higher Than } & \text { Gen Unimpt (2) } & 9 & 36.0 & \\ \text { Previous Years } & \text { Gen Impt (3) } & 9 & 36.0 & \\ \text { Goals } & \text { Very Impt (4) } & 1 & 04.0 & & \\ & \text { Missing (9) } & 5 & 20.0 & & \\ & & 25 & 100.0 & 2.500 & 0.688\end{array}$

Inflation

Plus $5-10 \%$

Major Effort

Based on an

Anniversary

(Or the Like)

Bealistic

Expectations

$\begin{array}{lllll}\text { Very Unimpt (1) } & 3 & 12.0 & & \\ \text { Gen Unimpt (2) } & 8 & 32.0 & & \\ \text { Gen Impt (3) } & 7 & 28.0 & & \\ \text { Very Impt (4) } & 0 & 00.0 & & \\ \text { Missing (9) } & \text { Z } & 28.0 & & \\ & 25 & 100.0 & 2.222 & 0.732\end{array}$

$\begin{array}{lllll}\text { Very Unimpt (1) } & 0 & 00.0 & & \\ \text { Gen Unimpt (2) } & 3 & 12.0 & & \\ \text { Gen Impt (3) } & 6 & 24.0 & & \\ \text { Very Impt (4) } & 11 & 44.0 & & \\ \text { Missing (9) } & 5 & 20.0 & & \\ & 25 & 100.0 & 3.400 & 0.754\end{array}$

$\begin{array}{lllll}\text { Very Unimpt (1) } & 0 & 00.0 & & \\ \text { Gen Unimpt (2) } & 1 & 04.0 & & \\ \text { Gen Impt (3) } & 7 & 28.0 & & \\ \text { Very Impt (4) } & 13 & 52.0 & & \\ \text { Missing (9) } & 4 & 160 & & \\ & 25 & 100.0 & 3.571 & 0.598\end{array}$


Q15 Does the school's development office use volunteers to solicit funds?

$\begin{array}{lllllll}\text { VIABIABLE } & \text { VALUE } & \text { F } & \% & M & \text { SD } \\ \text { Volunteers } & \text { Yes (1) } & 23 & 92.0 & & \\ & \text { No (2) } & 2 & 08.0 & & \\ & \text { Missing (9) } & 0 & \underline{00.0} & & \\ & & 25 & 100.0 & 1.080 & 0.277\end{array}$

Q16 How effective are the following methods and techniques in optimizing the school's fund raising efforts?

$\begin{array}{llllll}\text { VARIABLE } & \text { VALUE } & F & \% & M & \text { SD } \\ \text { Printed } & \text { Very Ineffct (1) } & 0 & 00.0 & & \\ \text { Brochures } & \text { Gen Ineffct (2) } & 4 & 16.0 & & \\ & \text { Gen Effct (3) } & 13 & 52.0 & & \\ & \text { Very Effct (4) } & 4 & 16.0 & & \\ & \text { Missing (9) } & 4 & 16.0 & & \\ & & 25 & 100.0 & 3.000 & 0.632\end{array}$

Computerized

$\begin{array}{lllll}\text { Very Ineffct (1) } & 2 & 08.0 & & \\ \text { Gen Ineffct (2) } & 8 & 32.0 & & \\ \text { Gen Effct (3) } & 7 & 28.0 & & \\ \text { Very Effct (4) } & 2 & 08.0 & & \\ \text { Missing (9) } & \underline{6} & \underline{24.0} & & \\ & 25 & 100.0 & 2.474 & 0.841\end{array}$

Personalized

$\begin{array}{lllll}\text { Very Ineffct (1) } & 0 & 00.0 & & \\ \text { Gen Ineffct (2) } & 1 & 04.0 & & \\ \text { Gen Effct (3) } & 10 & 40.0 & & \\ \text { Very Effct (4) } & 12 & 48.0 & & \\ \text { Missing (9) } & 2 & \underline{08.0} & & \\ & 25 & 100.0 & 3.478 & 0.593\end{array}$


VARIABLE

Humor in

Printed

Material

Annual

Themes

Suggested

GiftAmounts

Designated

Gifts

Class Agent

System

VALUE

Very Ineffct (1) $2 \quad 08.0$

Gen Ineffct (2) $2 \quad 08.0$

Gen Effct (3) $\quad 3 \quad 12.0$

$\begin{array}{lll}\text { Very Effct (4) } \quad 0 & 00.0\end{array}$

\begin{tabular}{lll} 
Missing (9) $\quad 18 \quad 72.0$ \\
\hline
\end{tabular}

$\begin{array}{llll}25 & 100.0 & 2.143 & 0.900\end{array}$

$\begin{array}{lllll}\text { Very Ineffct (1) } & 1 & 04.0 & \\ \text { Gen Ineffct (2) } & 4 & 16.0 & \\ \text { Gen Effct (3) } & 6 & 24.0 & \\ \text { Very Effct (4) } & 2 & 08.0 & & \\ \text { Missing (9) } & 12 & \underline{48.0} & & \\ & 25 & 100.0 & 2.692 & 0.855\end{array}$

\begin{tabular}{|c|c|c|c|}
\hline Very Ineffct (1) & 0 & 00.0 & \\
\hline Gen Ineffct (2) & 1 & 04.0 & \\
\hline Gen Effct (3) & 11 & 44.0 & \\
\hline Very Effct (4) & 10 & 40.0 & \\
\hline \multirow[t]{2}{*}{ Missing (9) } & 3 & 12.0 & \\
\hline & 25 & 100.0 & 3.409 \\
\hline
\end{tabular}

\begin{tabular}{|c|c|c|c|c|}
\hline Very Ineffct (1) & 0 & 00.0 & & \\
\hline Gen Ineffct (2) & 2 & 08.0 & & \\
\hline Gen Effct (3) & 10 & 40.0 & & \\
\hline Very Effct (4) & 8 & 32.0 & & \\
\hline \multirow[t]{2}{*}{ Missing (9) } & 5 & 20.0 & & \\
\hline & 25 & 100.0 & 3.300 & 0.657 \\
\hline
\end{tabular}

$\begin{array}{lllll}\text { Verry Ineffct (1) } & 1 & 04.0 & \\ \text { Gen Ineffct (2) } & 3 & 12.0 & \\ \text { Gen Effct (3) } & 6 & 24.0 & & \\ \text { Very Effct (4) } & 4 & 16.0 & & \\ \text { Missing (9) } & 11 & 44.0 & & \\ & 25 & 100.0 & 2.929 & 0.917\end{array}$




$\begin{array}{llllll}\text { VARIABLE } & \text { VALUE } & F & \% & M & \text { SD } \\ \text { Class } & \text { Very Ineffct (1) } & 0 & 00.0 & & \\ \text { Beunion } & \text { Gen Ineffct (2) } & 5 & 20.0 & \\ \text { Giving } & \text { Gen Effct (3) } & 3 & 12.0 & \\ & \text { Very Effct (4) } & 7 & 28.0 & & \\ & \text { Missing (9) } & 10 & 40.0 & & \\ & & 25 & 100.0 & 3.133 & 0.915\end{array}$

Phoning By

Students

\section{Phoning By}

Alumnii

Personal

Visits

Special Gift

Program

$\begin{array}{lllll}\text { Very Ineffct (1) } & 1 & 04.0 & & \\ \text { Gen Ineffct (2) } & 1 & 04.0 & & \\ \text { Gen Effct (3) } & 10 & 40.0 & & \\ \text { Very Effct (4) } & 7 & 28.0 & & \\ \text { Missing (9) } & 6 & 24.0 & & \\ & 25 & 100.0 & 3.211 & 0.787\end{array}$

$\begin{array}{llllll}\text { Very Inefict (1) } & 1 & 04.0 & & \\ \text { Gen Ineffct (2) } & 0 & 00.0 & & \\ \text { Gen Effct (3) } & 5 & 20.0 & & \\ \text { Very Effct (4) } & 12 & 48.0 & & \\ \text { Missing (9) } & \text { I } & 28.0 & & \\ & 25 & 100.0 & 3.556 & 0.784\end{array}$

$\begin{array}{lllll}\text { Very Ineffct (1) } & 0 & 00.0 & & \\ \text { Gen Ineffct (2) } & 1 & 04.0 & & \\ \text { Gen Effct (3) } & 4 & 16.0 & & \\ \text { Very Effct (4) } & 18 & 72.0 & & \\ \text { Missing (9) } & 2 & \underline{08.0} & & \\ & 25 & 100.0 & 3.739 & 0.541\end{array}$

$\begin{array}{llllll}\text { Very Ineffct (1) } & 0 & 00.0 & & \\ \text { Gen Ineffct (2) } & 0 & 00.0 & & \\ \text { Gen Effct (3) } & 10 & 40.0 & & \\ \text { Very Effct (4) } & 9 & 36.0 & & \\ \text { Missing (9) } & \underline{6} & \underline{24.0} & & \\ & 25 & 100.0 & 3.474 & 0.513\end{array}$


VARIABLE

Qutside

Professional

Counsel

Prospect

Besearch

Case

Statements

Organized

Groups of

Eriends

\begin{tabular}{llllll} 
VALUE & $\mathrm{F}$ & $\%$ & $\mathrm{M}$ & SD \\
\hline
\end{tabular}

Very Ineffct (1) $\quad 1 \quad 04.0$

Gen Ineffct (2) $\quad 4 \quad 16.0$

Gen Effct (3) $\quad 0 \quad 00.0$

Very Effct (4) $\quad 2 \quad 08.0$

Missing (9) $\quad 18 \quad 720$

$\begin{array}{llll}25 & 100.0 & 2.429 & 1.134\end{array}$

\begin{tabular}{|c|c|c|}
\hline Very Ineffct (1) & 1 & 04.0 \\
\hline Gen Ineffct (२) & 3 & 12.0 \\
\hline Gen Effct (3) & 10 & 40.0 \\
\hline Very Effct (4) & 6 & 24.0 \\
\hline Missing (9) & 5 & 20.0 \\
\hline & 25 & 100.0 \\
\hline
\end{tabular}

Very Ineffct (1) $\quad 1 \quad 04.0$

Gen Ineffct (2) $2 \quad 08.0$

Gen Effct (3) $\quad 9 \quad 36.0$

Very Effct (4) $\quad 2 \quad 08.0$

Missing (9) $\quad 11 \quad 44.0$

$\begin{array}{llll}25 & 100.0 & 2.857 & 0.770\end{array}$

Very Ineffct (1) $\quad 1 \quad 04.0$

Gen Ineffct (2) $\quad 1 \quad 04.0$

Gen Effct (3) $\quad 10 \quad 40.0$

Very Effct (4) $\quad 3 \quad 12.0$

Missing (9) $\quad 10 \quad 40.0$

$\begin{array}{llll}25 & 100.0 & 3.000 & 0.756\end{array}$ 
Q17 Funds raised from private sources can be designated for many uses. How altractive to the donor is each of the following in positively influencing them to contribute?

VARIABLE

Scholarships

$\begin{array}{lllll}\text { VALUE } & F & \% & M & \text { SD } \\ \text { Very Unattract (1) } & 0 & 00.0 & & \\ \text { Gen Unattract (2) } & 2 & 08.0 & & \\ \text { Gen Attract (3) } & 14 & 56.0 & & \\ \text { Very Attract (4) } & 8 & 32.0 & & \\ \text { Missing (9) } & 1 & \underline{04.0} & & \\ & 25 & 100.0 & 3.480 & 1.295\end{array}$

Endowment

$\begin{array}{llllll}\text { Very Unattract (1) } & 1 & 04.0 & & \\ \text { Gen Unattract (2) } & 0 & 00.0 & & \\ \text { Gen Attract (3) } & 17 & 68.0 & & \\ \text { Very Attract (4) } & 4 & 16.0 & & \\ \text { Missing (9) } & 3 & 12.0 & & \\ & 25 & 100.0 & 3.091 & 0.610\end{array}$

Specific

Very Unattract (1) $0 \quad 00.0$

Academic

Areas

Gen Unattract (2) $1 \quad 04.0$

Gen Attract (3) $12 \quad 48.0$

Very Attract (4) $9 \quad 36.0$

Missing (9) $\quad 3 \quad 120$

$\begin{array}{llll}25 & 100.0 & 3.364 & 0.581\end{array}$

Library

$\begin{array}{llllll}\text { Very Unattract (1) } & 6 & 24.0 & & \\ \text { Gen Unattract (2) } & 8 & 32.0 & & \\ \text { Gen Attract (3) } & 3 & 12.0 & & \\ \text { Very Attract (4) } & 0 & 00.0 & & \\ \text { Missing (9) } & \underline{8} & \underline{32.0} & & \\ & 25 & 100.0 & 1.824 & 0.728\end{array}$




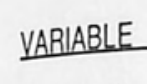

Endowed

Chairs

Eaculty

Projects

Special

Programs

Capital

Projects

$\begin{array}{lllll}\text { VALUE } & \text { F } & \% & \text { M } & \text { SD } \\ \text { Very Unattract (1) } & 1 & 04.0 & & \\ \text { Gen Unattract (2) } & 6 & 24.0 & & \\ \text { Gen Attract (3) } & 8 & 32.0 & & \\ \text { Very Attract (4) } & 5 & 20.0 & & \\ \text { Missing (9) } & 5 & 20.0 & & \\ & 25 & 100.0 & 2.850 & 0.875\end{array}$

$\begin{array}{lllll}\text { Very Unattract (1) } & 0 & 00.0 & \\ \text { Gen Unattract (2) } & 7 & 28.0 & \\ \text { Gen Attract (3) } & 9 & 36.0 & \\ \text { Very Attract (4) } & 2 & 08.0 & & \\ \text { Missing (9) } & \text { I } & 28.0 & & \\ & 25 & 100.0 & 2.722 & 0.669\end{array}$

Very Unattract (1) $0 \quad 00.0$

Gen Unattract (2) $1 \quad 04.0$

Gen Attract (3) $\quad 14 \quad 56.0$

Very Attract (4) $6 \quad 24.0$

Missing (9) $4 \quad 16.0$

$\begin{array}{llll}25 & 100.0 & 3.238 & 0.539\end{array}$

Very Unattract (1) $3 \quad 12.0$

Gen Unattract (2) $2 \quad 08.0$

Gen Attract (3) $\quad 10 \quad 40.0$

Very Attract (4) $7 \quad 28.0$

$\begin{array}{lll}\text { Missing (9) } \quad 3 & 120\end{array}$

$\begin{array}{llll}25 & 100.0 & 2.955 & 0.999\end{array}$ 
VARIABLE Gitt-In-Kind

\section{VALUE}

Very Unattract (1) 0

Gen Unattract (2) 2

Gen Attract (3)

Very Attract (4)

Missing (9)

14

$4 \quad 16.0$

$5 \quad 200$

$25 \quad 100.0$

Besearch

$\begin{array}{lllll}\text { Very Unattract (1) } & 3 & 12.0 & & \\ \text { Gen Unattract (2) } & 8 & 32.0 & & \\ \text { Gen Attract (3) } & 7 & 28.0 & & \\ \text { Very Attract (4) } & 2 & 08.0 & & \\ \text { Missing (9) } & 5 & \underline{20.0} & & \\ & 25 & 100.0 & 2.400 & 0.883\end{array}$




\section{DEVELOPMENT OFFICER SURVEY}

\section{DEMOGRAPHIC INFORMATION}

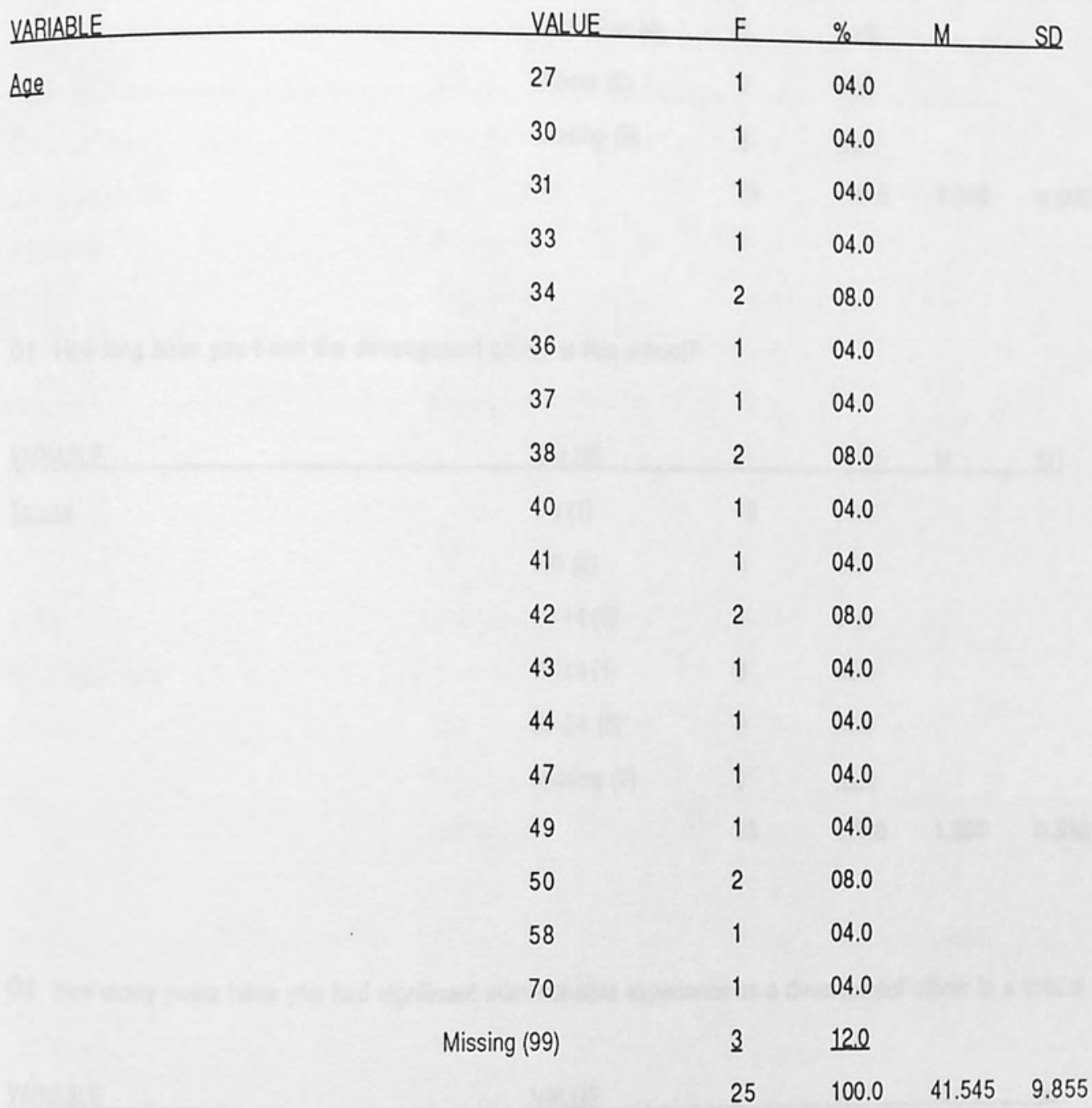

Gender

$\begin{array}{lllll}\text { Male (1) } & 8 & 32.0 & & \\ \text { Female (2) } & 14 & 56.0 & & \\ \text { Missing (9) } & 3 & 12.0 & & \\ & 25 & 100.0 & 1.636 & 0.492\end{array}$




$\begin{array}{llllll}\text { VARIABLE } & \text { VALUE } & F & \% & M & \text { SD } \\ \text { Ethnicity } & \text { Caucasian (1) } & 16 & 64.0 & & \\ & \text { Hispanic (2) } & 0 & 00.0 & & \\ \text { African-Am (3) } & 0 & 00.0 & \\ \text { Asian-Pac (4) } & 0 & 00.0 & & \\ \text { Others (5) } & 0 & 00.0 & & \\ \text { Missing (9) } & 9 & \underline{36.0} & & \\ & & 25 & 100.0 & 1.000 & 0.000\end{array}$

Q1 How long have you been the development officer at this school?

$\begin{array}{llllll}\text { VARIABLE } & \text { VALUE } & F & \% & M & \text { SD } \\ \text { Ienure } & 1-4(1) & 19 & 76.0 & & \\ & 5-9(2) & 4 & 16.0 & & \\ & 10-14(3) & 1 & 04.0 & & \\ & 15-19(4) & 0 & 00.0 & & \\ & 20-24(5) & 0 & 00.0 & & \\ & \text { Missing (9) } & 1 & \underline{04.0} & & \\ & & 25 & 100.0 & 1.250 & 0.532\end{array}$

Q2 How many years have you had significant administrative experience as a development officer in a school of dentistry?

$\begin{array}{llllll}\text { VARIABLE } & \text { VALUE } & F & \% & M & \text { SD } \\ \text { Experience } & 1-4(1) & 17 & 68.0 & & \\ & 5-9(2) & 2 & 08.0 & & \\ 10-14(3) & 2 & 08.0 & & \\ 15-19(4) & 0 & 00.0 & & \\ & 20-24(5) & 0 & 00.0 & & \\ \text { Missing (9) } & 1 & \underline{04.0} & & \\ & & 25 & 100.0 & 1.286 & 0.644\end{array}$




\section{DEAN INTERVIEW}

Q1 How active has the school been in performing each of the following tasks?

$\begin{array}{llllll}\text { VARIABLE } & \text { VALUE } & F & \% & M & \text { SD } \\ \text { Dev. Officerl } & \text { Very Inact (1) } & 0 & 00.0 & & \\ \text { Visit Major Fund } & \text { Gen Inact (2) } & 1 & 25.0 & & \\ \text { Prospects } & \text { Gen Act (3) } & 1 & 25.0 & & \\ & \text { Very Act (4) } & 2 & 50.0 & & \\ & \text { Not Appl (5) } & 0 & 00.0 & & \\ & \text { Missing (9) } & 0 & \underline{00.0} & & \\ & & 4 & 100.0 & 3.250 & 0.957\end{array}$

Deanl

Very Inact (1) $\quad 0 \quad 00.0$

Visit Major Fund

Gen Inact (2) $3 \quad 75.0$

Prospects

Gen Act (3) $\quad 0 \quad 00.0$

Very Act (4) $\quad 1 \quad 25.0$

$\begin{array}{lll}\text { Not Appl (5) } & 0 & 00.0\end{array}$

Missing (9) $\quad 0 \quad \underline{000}$

$\begin{array}{llll}4 & 100.0 & 2.500 & 1.000\end{array}$

\begin{tabular}{|c|c|c|c|c|}
\hline Proposals & Very Inact (1) & 0 & 00.0 & \\
\hline Io Major Fund & Gen Inact (2) & 2 & 50.0 & \\
\hline \multirow[t]{5}{*}{ Prospects } & Gen Act (3) & 2 & 50.0 & \\
\hline & Very Act (4) & 0 & 00.0 & \\
\hline & Not Appl (5) & 0 & 00.0 & \\
\hline & Missing (9) & 0 & 00.0 & \\
\hline & & 4 & 100.0 & 2.500 \\
\hline
\end{tabular}


(cont'd.)

$\begin{array}{llllll}\text { VARIABLE } & \text { VALUE } & F & \% & M & \text { SD } \\ \text { Eollow-upl } & \text { Very Inact (1) } & 0 & 00.0 & & \\ \text { Proposal } & \text { Gen Inact (2) } & 1 & 25.0 & & \\ & \text { Gen Act (3) } & 0 & 00.0 & \\ & \text { Very Act (4) } & 2 & 50.0 & \\ \text { Not Appl (5) } & 1 & 25.0 & & \\ & \text { Missing (9) } & 0 & \underline{00.0} & & \\ & & 4 & 100.0 & 3.750 & 1.258\end{array}$

Eollow-upl

$\begin{array}{lllll}\text { Very Inact (1) } & 0 & 00.0 & \\ \text { Gen Inact (2) } & 1 & 25.0 & \\ \text { Gen Act (3) } & 2 & 50.0 & \\ \text { Very Act (4) } & 0 & 00.0 & & \\ \text { Not Appl (5) } & 1 & 25.0 & & \\ \text { Missing (9) } & 0 & \underline{00.0} & & \\ & 4 & 100.0 & 3.250 & 1.258\end{array}$

Q2 How successful has the school been in each of the following:

\begin{tabular}{llllll} 
VARIABLE & VALUE & $F$ & $\%$ & $M$ & SD \\
\hline Obtaining & Very Unsuccsfl (1) & 0 & 00.0 & & \\
Grants & Gen Unsuccsfl (2) & 0 & 00.0 & & \\
& Gen Succsfl (3) & 3 & 75.0 & & \\
& Very Succsfl (4) & 1 & 25.0 & & \\
& Not Appl (5) & 0 & 00.0 & & \\
& Missing (9) & $\ell$ & $\underline{00.0}$ & & \\
& & 4 & 100.0 & 3.250 & 0.500
\end{tabular}


(cont'd.)

$\begin{array}{llllll}\text { VABIABLE } & \text { VALUE } & F & \% & M & \text { SD } \\ \text { Why } & \text { Very Unsuccsil (1) } & 0 & 00.0 & & \\ \text { Proposal } & \text { Gen Unsuccsil (2) } & 1 & 25.0 & & \\ \text { Nel Funded } & \text { Gen Succsfl (3) } & 2 & 50.0 & & \\ & \text { Very Succsil (4) } & 1 & 25.0 & & \\ & \text { Not Appl (5) } & 0 & 00.0 & & \\ & \text { Missing (9) } & 0 & \underline{00.0} & & \\ & & 4 & 100.0 & 3.000 & 0.816\end{array}$

$\begin{array}{llllll}\text { Obtaining } & \text { Very Unsuccsil (1) } & 0 & 00.0 & & \\ \text { Grantsl } & \text { Gen Unsuccsil (2) } & 1 & 25.0 & & \\ \text { Amt. Requested } & \text { Gen Succsil (3) } & 2 & 50.0 & \\ & \text { Very Succsil (4) } & 1 & 25.0 & & \\ & \text { Not Appl (5) } & 0 & 00.0 & & \\ & \text { Missing (9) } & \ell & \underline{00.0} & & \\ & & 4 & 100.0 & 3.000 & 0.816\end{array}$

Q3 How helpful would you say the following institutional features have been to the school in its attempt to obtain philanthropic support from $1987-88$ to $1990-91$ ?

$\begin{array}{llllll}\text { VARIABLE } & \text { VALUE } & F & \% & M & \text { SD } \\ \text { Geographic } & \text { Very Unhlpfl (1) } & 0 & 00.0 & & \\ \text { Location } & \text { Gen Unhlpfl (2) } & 0 & 00.0 & & \\ & \text { Gen Hlpfl (3) } & 2 & 50.0 & & \\ & \text { Very Hlpfl (4) } & 2 & 50.0 & & \\ & \text { Not Appl (5) } & 0 & 00.0 & & \\ & \text { Missing (9) } & 0 & \underline{00.0} & & \\ & & 4 & 100.0 & 3.500 & 0.577\end{array}$


(cont'd.)

VABIABLE

VALUE

$\% \quad M \quad S D$

University

Very Unhlpfl (1) $0 \quad 00.0$

Affiliation

Gen Unhlpfl (2) $\quad 0 \quad 00.0$

Gen Hlpfl (3) $\quad 2 \quad 50.0$

Very Hlpfl (4) $2 \quad 50.0$

$\begin{array}{lll}\text { Not Appl (5) } & 0 & 00.0\end{array}$

$\begin{array}{lll}\text { Missing (9) } \quad 00.0 & \end{array}$

$\begin{array}{llll}4 & 100.0 & 3.500 & 0.577\end{array}$

Historical

Very Unhlpfl (1) $\quad 0 \quad 00.0$

Bkad/Dev

Gen Unhlpfl (2) $\quad 1 \quad 25.0$

Gen Hlpfl (3) $\quad 2 \quad 50.0$

Very Hlpfl (4) $\quad 1 \quad 25.0$

$\begin{array}{lll}\text { Not Apl (5) } & 0 & 00.0\end{array}$

Missing (9) $2 \quad \underline{00.0}$

$\begin{array}{llll}4 & 100.0 & 3.000 & 0.816\end{array}$

Balanced

Budget

\begin{tabular}{|c|c|c|c|c|}
\hline Very Unhlpfl (1) & 0 & 00.0 & & \\
\hline Gen Unhlpfl (2) & 0 & 00.0 & & \\
\hline Gen Hlpfl (3) & 3 & 75.0 & & \\
\hline Very Hlpfl (4) & 0 & 00.0 & & \\
\hline Not Appl (5) & 1 & 25.0 & & \\
\hline \multirow[t]{2}{*}{ Missing (9) } & $\underline{Q}$ & 00.0 & & \\
\hline & 4 & 100 & 3.500 & 1.000 \\
\hline
\end{tabular}


(cont'd.)

$\begin{array}{llllll}\text { VABIABLE } & \text { VALUE } & F & \% & \text { M } & \text { SD } \\ \text { Indebt- } & \text { Very Unhlpfl (1) } & 0 & 00.0 & & \\ \text { edness } & \text { Gen Unhlpfl (2) } & 0 & 00.0 & \\ & \text { Gen Hlpfl (3) } & 1 & 25.0 & & \\ & \text { Very Hlpfl (4) } & 0 & 00.0 & & \\ & \text { Not Appl (5) } & 2 & 50.0 & & \\ & \text { Missing (9) } & 1 & 25.0 & & \\ & & 4 & 100.0 & 4.333 & 1.155\end{array}$

Strategic

Planning

$\begin{array}{lllll}\text { Very Unhlpfl (1) } & 0 & 00.0 & & \\ \text { Gen Unhlpfl (2) } & 0 & 00.0 & & \\ \text { Gen Hlpfl (3) } & 3 & 75.0 & & \\ \text { Very Hlpfl (4) } & 0 & 00.0 & & \\ \text { Not Appl (5) } & 0 & 00.0 & & \\ \text { Missing (9) } & 1 & 25.0 & & \\ & 4 & 100.0 & 3.000 & 0.000\end{array}$

Sizel

$\begin{array}{lllll}\text { Very Unhlpfl (1) } & 0 & 00.0 & & \\ \text { Gen Unhlpfl (2) } & 1 & 25.0 & & \\ \text { Gen Hlpfl (3) } & 2 & 50.0 & & \\ \text { Very Hlpfl (4) } & 1 & 25.0 & & \\ \text { Not Appl (5) } & 0 & 00.0 & & \\ \text { Missing (9) } & \mathbb{Q} & \underline{00.0} & & \\ & 4 & 100.0 & 3.000 & 0.816\end{array}$


Q4 How helpful have the following development office features been to the school it its attempt to obtain philanthropic support from $1987-88$ to $1990-91$ ?

$\begin{array}{llllll}\text { VARIABLE } & \text { VALUE } & F & \% & M & \text { SD } \\ \text { Dev. Officer/1 } & \text { Very Unhlpfl (1) } & 0 & 00.0 & & \\ \text { Ienure } & \text { Gen Unhlpfl (2) } & 0 & 00.0 & \\ & \text { Gen Hlpfl (3) } & 3 & 75.0 & \\ \text { Very Hlpfl (4) } & 1 & 25.0 & \\ \text { Not Appl (5) } & 0 & 00.0 & & \\ & \text { Missing (9) } & 0 & \underline{00.0} & & \\ & & 4 & 100.0 & 3.250 & 0.500\end{array}$

Dev. Officerl

Prof. Bkgd

Dev. Officel

EI Staff

\begin{tabular}{|c|c|c|c|}
\hline Very Unhlpfl (1) & 0 & 00.0 & \\
\hline Gen Unhlpfl (2) & 0 & 00.0 & \\
\hline Gen Hlpfl (3) & 2 & 50.0 & \\
\hline Very Hlpfl (4) & 2 & 50.0 & \\
\hline Not Appl (5) & 0 & 00.0 & \\
\hline \multirow{2}{*}{ Missing (9) } & 0 & 000 & \\
\hline & 4 & 100.0 & 3.500 \\
\hline
\end{tabular}

\begin{tabular}{|c|c|c|c|c|}
\hline Very Unhlpfl (1) & 0 & 00.0 & & \\
\hline Gen Unhlpfl (2) & 0 & 00.0 & & \\
\hline Gen Hlpfl (3) & 1 & 25.0 & & \\
\hline Very HIpfl (4) & 2 & 50.0 & & \\
\hline Not Appl (5) & 1 & 25.0 & & \\
\hline \multirow[t]{2}{*}{ Missing (9) } & Q & $\underline{000}$ & & \\
\hline & 4 & 100.0 & 4.000 & 0.81 \\
\hline
\end{tabular}


(cont'd.)

$\begin{array}{llllll}\text { VARIABLE } & \text { VALUE } & \text { F } & \% & \text { M } & \text { SD } \\ \text { Timel } & \text { Very Unhlpfl (1) } & 0 & 00.0 & \\ \text { Besearch } & \text { Gen Unhlpfl (2) } & 2 & 50.0 & \\ \text { Prospects } & \text { Gen Hlpfl (3) } & 2 & 50.0 & \\ & \text { Very Hlpfl (4) } & 0 & 00.0 & \\ & \text { Not Appl (5) } & 0 & 00.0 & \\ & \text { Missing (9) } & 0 & 00.0 & & \\ & & 4 & 100.0 & 2.500 & 0.577\end{array}$

Dev. Officel

Strategic

Planning

Numberl

Proposals

\begin{tabular}{|c|c|c|c|}
\hline Very Unhlpfl (1) & 0 & 00.0 & \\
\hline Gen Unhlpfl (२) & 1 & 25.0 & \\
\hline Gen Hlpfl (3) & 2 & 50.0 & \\
\hline Very Hlpfl (4) & 1 & 25.0 & \\
\hline Not Appl (5) & 0 & 00.0 & \\
\hline Missing (9) & $\underline{0}$ & $\underline{000}$ & \\
\hline & 4 & 100.0 & 3.000 \\
\hline
\end{tabular}

\begin{tabular}{|c|c|c|c|}
\hline Very Unhlpfl (1) & 0 & 00.0 & \\
\hline Gen Unhlpfl (2) & 1 & 25.0 & \\
\hline Gen Hlpfl (3) & 2 & 50.0 & \\
\hline Very HIpfl (4) & 0 & 00.0 & \\
\hline Not Appl (5) & 1 & 25.0 & \\
\hline \multirow[t]{2}{*}{ Missing (9) } & Q & 00.0 & \\
\hline & 4 & 100.0 & 3.250 \\
\hline
\end{tabular}


(cont'd.)

$\begin{array}{llllll}\text { VARIABLE } & \text { VALUE } & F & \% & \text { M } & \text { SD } \\ \text { Qualityl } & \text { Very Unhlpfl (1) } & 0 & 00.0 & & \\ \text { Proposals } & \text { Gen Unhlpfl (2) } & 0 & 00.0 & & \\ & \text { Gen Hlpfl (3) } & 1 & 25.0 & & \\ & \text { Very Hlpf (4) } & 2 & 50.0 & & \\ & \text { Not Appl (5) } & 1 & 25.0 & & \\ & \text { Missing (9) } & \ell & \underline{00.0} & & \\ & & 4 & 100.0 & 4.000 & 0.816\end{array}$

Q5 How often did you, as dean, participate in the following activities in the last academic year?

\begin{tabular}{|c|c|c|c|c|c|}
\hline VABIABLE & VALUE & $\mathrm{F}$ & $\%$ & M & SD \\
\hline Discuss & Within $1-3$ mos. (1) & 1 & 25.0 & & \\
\hline Grant Appll & Within 4-6 mos. (2) & 0 & 00.0 & & \\
\hline \multirow[t]{5}{*}{ Dev, Officer } & Within 7-9 mos. (3) & 0 & 00.0 & & \\
\hline & Within $10-12$ mos. (4) & 0 & 00.0 & 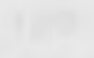 & \\
\hline & Not Appl (5) & 3 & 75.0 & & \\
\hline & Missing (9) & Q & 000 & & \\
\hline & & 4 & 100.0 & 4.000 & 2.000 \\
\hline Visit & Within $1-3$ mos. (1) & 2 & 50.0 & & \\
\hline Major Fund & Within 4-6 mos. (2) & 1 & 25.0 & & \\
\hline \multirow[t]{5}{*}{ Prospect } & Within 7-9 mos. (3) & 0 & 00.0 & & \\
\hline & Within $10-12$ mos. (4) & 0 & 00.0 & & \\
\hline & Not Appl (5) & 1 & 25.0 & & \\
\hline & Missing (9) & 2 & 000 & & \\
\hline & & 4 & 100.0 & 2.250 & 1.893 \\
\hline
\end{tabular}


(cont'd.)

$\begin{array}{llllll}\text { VARIABLE } & \text { VALUE } & F & \% & M & \text { SD } \\ \text { Discuss } & \text { Within 1-3 mos. (1) } & 4 & 100.0 & \\ \text { Eund Sources/ } & \text { Within 4-6 mos. (2) } & 0 & 000.0 & \\ \text { Dev. Officer } & \text { Within 7-9 mos. (3) } & 0 & 000.0 & \\ & \text { Within 10-12 mos. (4) } & 0 & 000.0 & \\ & \text { Not Appl (5) } & 0 & 000.0 & & \\ & \text { Missing (9) } & 0 & \underline{000.0} & & \\ & & 4 & 100.0 & 1.000 & 0.000\end{array}$

Meetingl

$\begin{array}{lllll}\text { Within 1-3 mos. (1) } & 3 & 75.0 & & \\ \text { Within 4-6 mos. (2) } & 1 & 25.0 & & \\ \text { Within 7-9 mos. (3) } & 0 & 00.0 & & \\ \text { Within 10-12 mos. (4) } & 0 & 00.0 & & \\ \text { Not Appl (5) } & 0 & 00.0 & & \\ \text { Missing (9) } & 0 & \underline{00.0} & & \\ & 4 & 100.0 & 1.250 & 0.500\end{array}$




\section{DEVELOPMENT OFFICER INTERVIEW}

Q1 How active has the school been in performing each of the following tasks?

$\begin{array}{llllll}\text { VARIABLE } & \text { VALUE } & \text { F } & \% & \text { M } & \text { SD } \\ \text { Dev. Officerl } & \text { Very Inact (1) } & 0 & 00.0 & & \\ \text { Visit Major Fund } & \text { Gen Inact (2) } & 1 & 25.0 & & \\ \text { Prospects } & \text { Gen Act (3) } & 0 & 00.0 & & \\ & \text { Very Act (4) } & 3 & 75.0 & & \\ & \text { Not Appl (5) } & 0 & 00.0 & & \\ & \text { Missing (9) } & 0 & \underline{00.0} & & \\ & & 4 & 100.0 & 3.500 & 1.000\end{array}$

Deanl

Visit Major Fund

Very Inact (1) $\quad 0 \quad 00.0$

Prospects

Gen Inact (2) $2 \quad 50.0$

Gen Act (3) $\quad 1 \quad 25.0$

Very Act (4) $\quad 1 \quad 25.0$

Not Appl (5) $\quad 0 \quad 00.0$

Missing (9) $\quad 0 \quad 00.0$

$\begin{array}{llll}4 & 100.0 & 2.750 & 0.957\end{array}$

$\begin{array}{llllll}\text { Proposals } & \text { Very Inact (1) } & 1 & 25.0 & & \\ \text { Io Major Fund } & \text { Gen Inact (2) } & 0 & 00.0 & & \\ \text { Prospects } & \text { Gen Act (3) } & 3 & 75.0 & & \\ & \text { Very Act (4) } & 0 & 00.0 & & \\ & \text { Not Appl (5) } & 0 & 00.0 & & \\ & \text { Missing (9) } & 0 & \underline{00.0} & & \\ & & 4 & 100.0 & 2.500 & 1.000\end{array}$


(cont'd.)

$\begin{array}{llllll}\text { VABIABLE } & \text { VALUE } & F & \% & M & \text { SD } \\ \text { Eellow-UDI } & \text { Very Inact (1) } & 1 & 25.0 & & \\ \text { Propesal } & \text { Gen Inact (2) } & 0 & 00.0 & & \\ & \text { Gen Act (3) } & 0 & 00.0 & & \\ & \text { Very Act (4) } & 1 & 25.0 & & \\ & \text { Not Appl (5) } & 2 & 50.0 & & \\ & \text { Missing (9) } & 0 & \underline{00.0} & & \\ & & 4 & 100.0 & 3.750 & 1.893\end{array}$

Eellow-upl

$\begin{array}{lllll}\text { Very Inact (1) } & 0 & 00.0 & & \\ \text { Gen Inact (2) } & 1 & 25.0 & & \\ \text { Gen Act (3) } & 2 & 50.0 & & \\ \text { Very Act (4) } & 0 & 00.0 & & \\ \text { Not Appl (5) } & 0 & 00.0 & & \\ \text { Missing (9) } & 1 & 25.0 & & \\ & 4 & 100.0 & 2.667 & 0.577\end{array}$

Q2 How successful has the school been in each of the following:

\begin{tabular}{llllll} 
VARIABLE & VALUE & $F$ & $\%$ & $M$ & SD \\
\hline Obtaining & Very Unsuccsil (1) & 0 & 00.0 & & \\
Grants & Gen Unsuccsfl (2) & 1 & 25.0 & & \\
& Gen Succsfl (3) & 1 & 25.0 & & \\
& Very Succsil (4) & 1 & 25.0 & & \\
& Not Appl (5) & 0 & 00.0 & & \\
& Missing (9) & 1 & 25.0 & & \\
& & 4 & 100.0 & 3.000 & 1.000
\end{tabular}


(cont'd.)

$\begin{array}{llllll}\text { VAABIABLE } & \text { VALUE } & F & \% & M & \text { SD } \\ \text { Why } & \text { Very Unsuccsfl (1) } & 0 & 00.0 & \\ \text { Proposal } & \text { Gen Unsuccsil (2) } & 0 & 00.0 & \\ \text { Net Funded } & \text { Gen Succsfl (3) } & 1 & 25.0 & \\ & \text { Very Succsfl (4) } & 2 & 50.0 \\ & \text { Not Appl (5) } & 0 & 00.0 & \\ & \text { Missing (9) } & 1 & 25.0 & & \\ & & 4 & 100.0 & 3.667 & 0.577\end{array}$

Obtaining

Very Unsuccsfl (1) $0 \quad 00.0$

Grants/

Gen Unsuccsfl (2) $0 \quad 00.0$

Amt. Requested

Gen Succsfl (3) $\quad 1 \quad 25.0$

Very Succsil (4) $\quad 1 \quad 25.0$

Not Appl (5) $\quad 0 \quad 00.0$

Missing (9) $2 \quad 50.0$

$\begin{array}{llll}4 & 100.0 & 3.500 & 0.707\end{array}$

Q3 How helpful would you say the following institutional features have been to the school in its attempt to obtain philanthropic support from 1987-88 to $1990-91$ ?

$\begin{array}{llllll}\text { VARIABLE } & \text { VALUE } & \text { F } & \% & \text { M } & \text { SD } \\ \text { Geographic } & \text { Very Unhlpfl (1) } & 0 & 00.0 & \\ \text { Location } & \text { Gen Unhlpfl (2) } & 0 & 00.0 & \\ & \text { Gen Hlpfl (3) } & 1 & 25.0 & \\ & \text { Very Hlpfl (4) } & 1 & 25.0 & \\ & \text { Not Appl (5) } & 1 & 25.0 & \\ & \text { Missing (9) } & 1 & 25.0 & & \\ & & 4 & 100.0 & 4.000 & 1.000\end{array}$


(cont'd.)

$\begin{array}{llllll}\text { VAARIABLE } & \text { VALUE } & F & \% & M & \text { SD } \\ \text { University } & \text { Very Unhlpfl (1) } & 0 & 00.0 & & \\ \text { Afifiliation } & \text { Gen Unhlpfl (2) } & 0 & 00.0 & & \\ & \text { Gen Hlpfl (3) } & 1 & 25.0 & & \\ & \text { Very Hlpfl (4) } & 3 & 75.0 & & \\ & \text { Not Appl (5) } & 0 & 00.0 & & \\ & \text { Missing (9) } & 0 & \underline{00.0} & & \\ & & 4 & 100.0 & 3.750 & 0.500\end{array}$

Historical

Bkgd/Dev

$\begin{array}{lllll}\text { Very Unhlpfl (1) } & 0 & 00.0 & & \\ \text { Gen Unhlpfl (2) } & 1 & 25.0 & & \\ \text { Gen Hlpfl (3) } & 2 & 50.0 & & \\ \text { Very Hlpfl (4) } & 1 & 25.0 & & \\ \text { Not Appl (5) } & 0 & 00.0 & & \\ \text { Missing (9) } & 0 & \underline{00.0} & & \\ & 4 & 100.0 & 3.000 & 0.816\end{array}$

Balanced

Very Unhlpfl (1) $0 \quad 00.0$

Budget

$\begin{array}{lllll}\text { Gen Unhlpfl (2) } & 0 & 00.0 & & \\ \text { Gen Hlpfl (3) } & 2 & 50.0 & & \\ \text { Very Hlpfl (4) } & 1 & 25.0 & & \\ \text { Not Appl (5) } & 1 & 25.0 & & \\ \text { Missing (9) } & 0 & \underline{00.0} & & \\ & 4 & 100.0 & 3.750 & 0.957\end{array}$


(con'd.)

$\begin{array}{llllll}\text { VARIABLE } & \text { VALUE } & \text { F } & \% & M & \text { SD } \\ \text { Indebt. } & \text { Very Unhlpfl (1) } & 0 & 00.0 & & \\ \text { edness } & \text { Gen Unhlpfl (2) } & 1 & 25.0 & & \\ & \text { Gen Hlpfl (3) } & 0 & 00.0 & \\ & \text { Very Hlpfl (4) } & 0 & 00.0 & \\ \text { Not Appl (5) } & 2 & 50.0 & & \\ & \text { Missing (9) } & 1 & 25.0 & & \\ & & 4 & 100.0 & 4.000 & 1.732\end{array}$

Strategic

Very Unhlpfl (1) $1 . \quad 25.0$

Planning

Gen Unhlpfl (2) $0 \quad 00.0$

Gen Hlpfl (3) $\quad 1 \quad 25.0$

Very Hlpfl (4) $\quad 1 \quad 25.0$

Not Appl (5) $\quad 0 \quad 00.0$

Missing (9) $\quad 1 \quad 25.0$

$\begin{array}{llll}4 & 100.0 & 2.667 & 1.528\end{array}$

Sizel

Very Unhlpfl (1) $\quad 0 \quad 00.0$

Gen Unhlpfl (2) 125.0

Gen Hlpfl (3) $\quad 1 \quad 25.0$

Very Hlpfl (4) $\quad 1 \quad 25.0$

Not Appl (5) $\quad 0 \quad 00.0$

Missing (9) $\quad 1 \quad 25.0$

$\begin{array}{llll}4 & 100.0 & 3.000 & 1.000\end{array}$ 
Q4 How helpful have the following development office features been to the school in its attempt to obtain philanthropic support from $1987-88$ to $1990-91$ ?

$\begin{array}{llllll}\text { VAARIABLE } & \text { VALUE } & F & \% & M & \text { SD } \\ \text { Dev, Officerl } & \text { Very Unhlpfl (1) } & 0 & 00.0 & & \\ \text { Ienure } & \text { Gen Unhlpfl (2) } & 1 & 25.0 & & \\ & \text { Gen Hlpfl (3) } & 2 & 50.0 & & \\ & \text { Very Hlpfl (4) } & 0 & 00.0 & & \\ & \text { Not Appl (5) } & 1 & 25.0 & & \\ \text { Missing (9) } & 0 & 000 & & \\ & & 4 & 100.0 & 3.250 & 1.258\end{array}$

Dev. Officerl

$\begin{array}{lllll}\text { Very Unhlpfl (1) } & 0 & 00.0 & & \\ \text { Gen Unhlpfl (2) } & 1 & 2.50 & & \\ \text { Gen Hlpfl (3) } & 1 & 25.0 & & \\ \text { Very HIpfl (4) } & 2 & 50.0 & & \\ \text { Not Appl (4) } & 0 & 00.0 & & \\ \text { Missing (9) } & 0 & \underline{00.0} & & \\ & 4 & 100.0 & 3.250 & 0.957\end{array}$

Dev. Officel

Very Unhlpfl (1) $\quad 0 \quad 00.0$

EI Staff

Gen Unhlpfl (2) $2 \quad 50.0$

Gen Hlpfl (3) $\quad 1 \quad 25.0$

Very Hlpfl (4) $\quad 1 \quad 25.0$

Not Appl (5) $\quad 0 \quad 00.0$

Missing (9) $\quad 0 \quad \underline{00.0}$

$\begin{array}{llll}4 & 100.0 & 2.750 & 0.957\end{array}$ 
(cont'd.)

$\begin{array}{llllll}\text { VARIABLE } & \text { VALUE } & F & \% & M & \text { SD } \\ \text { Iimel } & \text { Very Unhlpfl (1) } & 0 & 00.0 & & \\ \text { Besearch } & \text { Gen Unhlpfl (2) } & 1 & 25.0 & & \\ \text { Prospects } & \text { Gen Hlpfl (3) } & 1 & 25.0 & & \\ & \text { Very Hlpfl (4) } & 1 & 25.0 & & \\ & \text { Not Appl (5) } & 0 & 00.0 & & \\ & \text { Missing (9) } & 1 & 25.0 & & \\ & & 4 & 100.0 & 3.000 & 1.000\end{array}$

Dev. Officel

Strategic

Planning

Numberl

Proposals

$\begin{array}{lllll}\text { Very Unhlpfl (1) } & 0 & 00.0 & & \\ \text { Gen Unhlpfl (2) } & 0 & 00.0 & & \\ \text { Gen Hlpfl (3) } & 2 & 50.0 & & \\ \text { Very Hlpfl (4) } & 1 & 25.0 & & \\ \text { Not Appl (5) } & 1 & 25.0 & & \\ \text { Missing (9) } & \mathbb{Q} & \underline{00.0} & & \\ & 4 & 100.0 & 3.750 & 0.957\end{array}$

Very Unhlpfl (1) $0 \quad 00.0$

Gen Unhlpfl (2) $3 \quad 75.0$

Gen Hlpfl (3) $\quad 0 \quad 0.0$

$\begin{array}{lll}\text { Very Hlpfl (4) } \quad 0 & 00.0\end{array}$

Not Appl (5) $\quad 0 \quad 00.0$

Missing (9) $\quad 1 \quad 25.0$

$\begin{array}{llll}4 & 100.0 & 2.000 & 0.000\end{array}$ 
(cont'd.)

$\begin{array}{llllll}\text { VABIABLE } & \text { VALUE } & F & \% & M & \text { SD } \\ \text { Qualityl } & \text { Very Unhlpfl (1) } & 0 & 00.0 & & \\ \text { Proposals } & \text { Gen Unhlpfl (2) } & 1 & 25.0 & & \\ & \text { Gen Hlpfl (3) } & 0 & 00.0 & & \\ & \text { Very Hlpfl (4) } & 2 & 50.0 & & \\ & \text { Not Appl (5) } & 0 & 00.0 & & \\ & \text { Missing (9) } & 1 & 25.0 & & \\ & & 4 & 100.0 & 3.333 & 1.155\end{array}$

Q5 How often did you, as development officer, participate in the following activities in the last academic year?

$\begin{array}{llllll}\text { VARIABLE } & \text { VALUE } & F & \% & M & \text { SD } \\ \text { Dliscuss } & \text { Within 1-3 mos. (1) } & 3 & 75.0 & & \\ \text { Grant Appll } & \text { Within 4-6 mos. (2) } & 0 & 00.0 & \\ \text { Dean } & \text { Within 7-9 mos. (3) } & 0 & 00.0 & & \\ & \text { Within 10-12 mos. (4) } & 1 & 25.0 & & \\ & \text { Not Appl (5) } & 0 & 00.0 & & \\ & \text { Missing (9) } & 0 & \underline{00.0} & & \\ & & 4 & 100.0 & 1.750 & 1.500\end{array}$

Yisit

$\begin{array}{lllll}\text { Within 1-3 mos. (1) } & 1 & 25.0 & & \\ \text { Within 4-6 mos. (2) } & 2 & 50.0 & & \\ \text { Within 7-9 mos. (3) } & 0 & 00.0 & & \\ \text { Within 10-12 mos. (4) } & 1 & 25.0 & & \\ \text { Not Appl (5) } & 0 & 00.0 & & \\ \text { Missing (9) } & 0 & \underline{00.0} & & \\ & 4 & 100.0 & 2.250 & 1.258\end{array}$


(cont'd.)

$\begin{array}{llllll}\text { VAABIABLE } & \text { VALUE } & F & \% & M & \text { SD } \\ \text { Discuss } & \text { Within 1-3 mos. (1) } & 4 & 100.0 & \\ \text { Eund Sources/ } & \text { Within 4-6 mos. (2) } & 0 & 00.0 & \\ \text { Dean } & \text { Within 7-9 mos. (3) } & 0 & 00.0 & \\ & \text { Within 10-12 mos. (4) } & 0 & 00.0 & & \\ & \text { Not Appl (5) } & 0 & 00.0 & & \\ & \text { Missing (9) } & 0 & \underline{00.0} & & \\ & & 4 & 100.0 & 1.000 & 0.000\end{array}$

Meetingl

$\begin{array}{lllll}\text { Within 1-3 mos. (1) } & 4 & 100.0 & & \\ \text { Within 4-6 mos. (2) } & 0 & 000.0 & & \\ \text { Within 7-9 mos. (3) } & 0 & 000.0 & & \\ \text { Within 10-12 mos. (4) } & 0 & 000.0 & & \\ \text { Not Appl (5) } & 0 & 000.0 & & \\ \text { Missing (9) } & \mathbb{0} & \underline{000.0} & & \\ & 4 & 100.0 & 1.000 & 0.000\end{array}$


APPENDIX

M 
DEAN INTERVIEW

DEVELOPMENT OFFICER INTERVIEW

Q1 How active has the school been in performing each of the following tasks:

- Development officer visiting major funding prospects

Deans

VALUE

Very Inact (1)

Gen Inact (2)

Gen Act (3)

Very Act (4)

Not Appl (5)

Missing (9)

Mean 3.3

SD 1.0
Development Officers

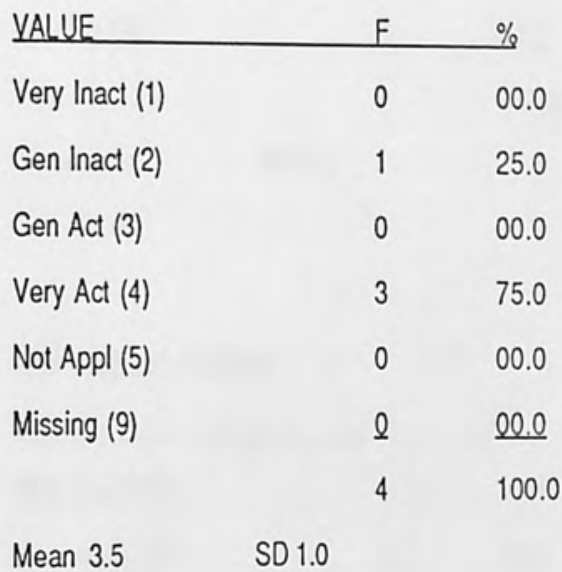

\section{Development Officers}

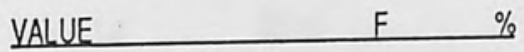

Very Inact (1) $\quad 00.0$

Gen Inact (2) $\quad 2 \quad 50.0$

Gen Act (3) $\quad 1 \quad 25.0$

$\begin{array}{lll}\text { Very Act (4) } & 1 & 25.0\end{array}$

$\begin{array}{lll}\text { Not Appl (5) } & 0 & 00.0\end{array}$

$\begin{array}{lll}\text { Missing (9) } & 0 & 00.0 \\ & 4 & 100.0\end{array}$

Mean $2.8 \quad$ SD 1.0 
- Proposals to major funding prospects

$\begin{array}{lll}\text { Deans } & \text { F } & \% \\ \text { ValuE } & 0 & 00.0 \\ \text { Very Inact (1) } & 2 & 50.0 \\ \text { Gen Inact (2) } & 2 & 50.0 \\ \text { Gen Act (3) } & 0 & 00.0 \\ \text { Very Act (4) } & 0 & 00.0 \\ \text { Not Appl (5) } & 0 & 00.0 \\ \text { Missing (9) } & 4 & 100.0\end{array}$

Mean $2.5 \quad$ SD 0.6

- Follow-up on submitted proposal

Deans

\begin{tabular}{lll} 
VALUE & F & $\%$ \\
\hline Very Inact (1) & 0 & 00.0 \\
Gen Inact (2) & 1 & 25.0 \\
Gen Act (3) & 0 & 00.0 \\
Very Act (4) & 2 & 50.0 \\
Not Appl (5) & 1 & 25.0 \\
Missing (9) & 0 & 00.0 \\
& 4 & 100.0
\end{tabular}

Mean $3.8 \quad$ SD 1.3

- Follow-up on rejected proposal

Deans

VALUE

Very Inact (1)

Gen Inact (2)

Gen Act (3)

Very Act (4)

Not Appl (5)

Missing (9)

Mean 3.3

$\begin{array}{ll}F & \% \\ 0 & 00.0 \\ 1 & 25.0 \\ 2 & 50.0 \\ 0 & 00.0 \\ 1 & 25.0 \\ \text { Q } & 00.0 \\ 4 & 100.0\end{array}$

SD 1.3
Development Officers

\begin{tabular}{lll} 
VALUE & F & $\%$ \\
\hline Very Inact (1) & 1 & 25.0 \\
Gen Inact (2) & 0 & 00.0 \\
Gen Act (3) & 3 & 75.0 \\
Very Act (4) & 0 & 00.0 \\
Not Appl (5) & 0 & 00.0 \\
Missing (9) & $\ell$ & $\underline{00.0}$ \\
& 4 & 100.0
\end{tabular}

Mean 2.5 SD 1.0

Development Officers

\begin{tabular}{lll} 
VALUE & F & $\%$ \\
\hline Very Inact (1) & 1 & 25.0 \\
Gen Inact (2) & 0 & 00.0 \\
Gen Act (3) & 0 & 00.0 \\
Very Act (4) & 1 & 25.0 \\
Not Appl (5) & 2 & 50.0 \\
Missing (9) & 2 & 00.0 \\
& 4 & 100.0
\end{tabular}

Mean $3.8 \quad$ SD 1.9

\section{Development Officers}

\begin{tabular}{lll} 
VALUE & $F$ & $\%$ \\
\hline Very Inact (1) & 0 & 00.0 \\
Gen Inact (2) & 1 & 25.0 \\
Gen Act (3) & 2 & 50.0 \\
Very Act (4) & 0 & 00.0 \\
Not Appl (5) & 0 & 00.0 \\
Missing (9) & 1 & 25.0 \\
& 4 & 100.0
\end{tabular}

Mean 2.7

SD 0.6 
Q2 How successful has the school been in each of the following:

- Obtaining grants

Deans

VALUE

Very Unsuccsil (1)

Gen Unsuccosil (2)

Gen Succsil (3)

Very Succsil (4)

Not Appl (5)

Missing (9)

SD 0.5

\section{Development Officers}

YALUE $\quad F \quad \%$

Very Unsuccsil (1) $\quad 0 \quad 00.0$

Gen Unsuccsil (2) $\quad 1 \quad 25.0$

Gen Succsil (3) $\quad 1 \quad 25.0$

$\begin{array}{lll}\text { Very Succsil (4) } & 1 & 25.0\end{array}$

$\begin{array}{lll}\text { Not Appl (5) } & 0 & 00.0\end{array}$

Missing (9) $\quad 1 \quad 25.0$

$4 \quad 100.0$

Mean $3.0 \quad$ SD 1.0

\section{Development Officers}

VALUE $\quad F \quad \%$

$\begin{array}{lll}\text { Very Unsuccsil (1) } & 0 & 00.0\end{array}$

$\begin{array}{lll}\text { Gen Unsuccsil (2) } & 0 & 00.0\end{array}$

Gen Succsil (3) $\quad 1 \quad 25.0$

$\begin{array}{lll}\text { Very Succsil (4) } \quad 2 & 50.0\end{array}$

Not Appl (5) $\quad 0 \quad 00.0$

Missing (9) $\quad 1 \quad 25.0$

$4 \quad 100.0$

Mean $3.7 \quad$ SD 0.6

\section{Development Officers}

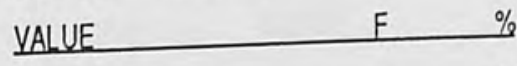

$\begin{array}{lll}\text { Very Unsuccsil (1) } \quad 00.0 & 0\end{array}$

Gen Unsuccsil (2) $\quad 0 \quad 00.0$

Gen Succsil (3) $\quad 1 \quad 25.0$

Very Succsil (4) $\quad 1 \quad 25.0$

Not Appl (5) $\quad 0 \quad 00.0$

$\begin{array}{lll}\text { Missing (9) } & 2 & 50.0 \\ & 4 & 100.0\end{array}$

Mean $3.5 \quad$ SD 0.7 
Q3 How helpful would you say the following institutional features have been to the school in its attempt to obtain philanthropic support from 1987-88 to 1990-91:

- Geographic location

Deans

\begin{tabular}{lll} 
VALUE & F & $\%$ \\
\hline Very Unhlpfl (1) & 0 & 00.0 \\
Gen Unhlpfl (2) & 0 & 00.0 \\
Gen Hlpfl (3) & 2 & 50.0 \\
Very Hlpil (4) & 2 & 50.0 \\
Not Appl (5) & 0 & 00.0 \\
Missing (9) & 0 & 00.0 \\
& 4 & 100.0
\end{tabular}

Mean 3.5

SD 0.6

0 University affiliation

Deans

$\begin{array}{lll}\text { VALUE } & \text { F } & \% \\ \text { Very Unhlpil (1) } & 0 & 00.0 \\ \text { Gen Unhlpfl (2) } & 0 & 00.0 \\ \text { Gen HIpfl (3) } & 2 & 50.0 \\ \text { Very Hlpfl (4) } & 2 & 50.0 \\ \text { Not Appl (5) } & 0 & 00.0 \\ \text { Missing (9) } & \ell & 00.0 \\ & 4 & 100.0\end{array}$

Mean 3.5

SD 0.6

\section{Development Officers}

\begin{tabular}{|c|c|c|}
\hline YALUE & $F$ & $\%$ \\
\hline Very Unhlpfl (1) & 0 & 00.0 \\
\hline Gen Unhlpfl (2) & 0 & 00.0 \\
\hline Gen Hlpfl (3) & 1 & 25.0 \\
\hline Very Hllpil (4) & 1 & 25.0 \\
\hline Not Appl (5) & 1 & 25.0 \\
\hline \multirow[t]{2}{*}{ Missing (9) } & 1 & 25.0 \\
\hline & 4 & 100.0 \\
\hline Mean 4.0 & & \\
\hline
\end{tabular}

\section{Development Officers}

$\begin{array}{lll}\text { VALUE } & \text { F } & \% \\ \text { Very Unhlpfl (1) } & 0 & 00.0 \\ \text { Gen Unhlpfl (2) } & 0 & 00.0 \\ \text { Gen Hlpfl (3) } & 1 & 25.0 \\ \text { Very Hlpfl (4) } & 3 & 75.0 \\ \text { Not Appl (5) } & 0 & 00.0 \\ \text { Missing (9) } & 0 & 00.0 \\ & 4 & 100.0\end{array}$

Mean 3.8

SD 0.5 
- Historical background and development

Deans

$\begin{array}{lll}\text { VALUE } & \text { F } & \% \\ \text { Very Unhlpil (1) } & 0 & 00.0 \\ \text { Gen Unhlpfl (2) } & 1 & 25.0 \\ \text { Gen HIpfl (3) } & 2 & 50.0 \\ \text { Very Hllpfl (4) } & 1 & 25.0 \\ \text { Not Appl (5) } & 0 & 00.0 \\ \text { Missing (9) } & 0 & 00.0 \\ & 4 & 100.0\end{array}$

Mean $3.0 \quad$ SD 0.8

- Balanced budget

Deans

VALUE $\quad F \quad \%$

$\begin{array}{lll}\text { Very Unhlpfl (1) } & 0 & 00.0\end{array}$

$\begin{array}{lll}\text { Gen Unhlpfl (2) } & 0 & 00.0\end{array}$

$\begin{array}{lll}\text { Gen Hlpfl (3) } & 3 & 75.0\end{array}$

$\begin{array}{lll}\text { Very Hlpil (4) } & 0 & 0.0\end{array}$

$\begin{array}{lll}\text { Not Appl (5) } & 1 & 25.0\end{array}$

$\begin{array}{lll}\text { Missing (9) } & 0 & 00.0\end{array}$

$4 \quad 100.0$

Mean 3.5 SD 1.0

- Indebtedness

Deans

$\begin{array}{lll}\text { VALUE } & \text { F } & \% \\ \text { Very Unhlpfl (1) } & 0 & 00.0 \\ \text { Gen Unhlpil (2) } & 0 & 00.0 \\ \text { Gen Hlpfl (3) } & 1 & 25.0 \\ \text { Very Hlpfl (4) } & 0 & 00.0 \\ \text { Not Appl (5) } & 2 & 50.0 \\ \text { Missing (9) } & 1 & 25.0 \\ & 4 & 100.0\end{array}$

Mean 4.3

Development Officers

\begin{tabular}{lll} 
VALUE & F & $\%$ \\
\hline Very Unhlpil (1) & 0 & 00.0 \\
Gen Unhlpfl (2) & 1 & 25.0 \\
Gen Hlpfl (3) & 2 & 50.0 \\
Very Hlpil (4) & 1 & 25.0 \\
Not Appl (5) & 0 & 00.0 \\
Missing (9) & $\ell$ & 00.0 \\
& 4 & 100.0
\end{tabular}

Mean $3.0 \quad$ SD 0.8

Development Officers

\begin{tabular}{lll} 
VALUE & F & $\%$ \\
\hline Very Unhlpfl (1) & 0 & 00.0 \\
Gen Unhlpfl (2) & 0 & 00.0 \\
Gen Hlpfl (3) & 2 & 50.0 \\
Very Hlpfl (4) & 1 & 25.0 \\
Not Appl (5) & 1 & 25.0 \\
Missing (9) & $\ell$ & 00.0 \\
& 4 & 100.0
\end{tabular}

Mean $3.8 \quad$ SD 1.0

Development Officers

$\begin{array}{lcc}\text { VALUE } & F & \% \\ \text { Very Unhlpfl (1) } & 0 & 00.0 \\ \text { Gen Unhlpfl (2) } & 1 & 25.0 \\ \text { Gen Hlpil (3) } & 0 & 00.0 \\ \text { Very Hllfl (4) } & 0 & 00.0 \\ \text { Not Appl (5) } & 2 & 50.0 \\ \text { Missing (9) } & 1 & 25.0 \\ & 4 & 100.0 \\ \text { Mean } 4.0 & \text { SD 1.7 } & \end{array}$


- Strategic planning

Deans

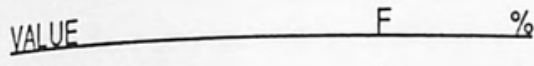

Very Unhlpfl (1) $\quad 000.0$

Gen Unhlpfl (2) $\quad 0 \quad 00.0$

Gen Hlpil (3) $\quad 3 \quad 75.0$

$\begin{array}{lll}\text { Very Hlpil (4) } & 0 & 00.0\end{array}$

$\begin{array}{lll}\text { Not Appl (5) } & 0 & 00.0\end{array}$

Missing (9) $\quad 1 \quad 25.0$

$4 \quad 100.0$

Mean 3.0

SD 0.0

$0 \quad$ Size and enrollment

Deans

\begin{tabular}{lll} 
VALUE & F & $\%$ \\
\hline Very Unhlpfl (1) & 0 & 00.0 \\
Gen Unhlpfl (2) & 1 & 25.0 \\
Gen HIpfl (3) & 2 & 50.0 \\
Very Hlpfl (4) & 1 & 25.0 \\
Not Appl (5) & 0 & 00.0 \\
Missing (9) & 0 & 00.0 \\
& 4 & 100.0
\end{tabular}

Mean 3.0

SD 0.8

\section{Development Officers}

\begin{tabular}{lll} 
YALUE & F & $\%$ \\
\hline Very Unhlpil (1) & 1 & 25.0 \\
Gen Unhlpil (2) & 0 & 00.0 \\
Gen Hlpfl (3) & 1 & 25.0 \\
Very Hlpil (4) & 1 & 25.0 \\
Not Appl (5) & 0 & 00.0 \\
Missing (9) & 1 & 25.0 \\
& 4 & 100.0
\end{tabular}

Mean $2.7 \quad$ SD 1.5

\section{Development Officers}

\begin{tabular}{|c|c|c|}
\hline VALUE & $F$ & $\%$ \\
\hline Very Unhlpfl (1) & 0 & 00.0 \\
\hline Gen Unhlpfl (2) & 1 & 25.0 \\
\hline Gen Hlpil (3) & 1 & 25.0 \\
\hline Very Hlpil (4) & 1 & 25.0 \\
\hline Not Appl (5) & 0 & 00.0 \\
\hline \multirow[t]{2}{*}{ Missing (9) } & 1 & 25.0 \\
\hline & 4 & 100.0 \\
\hline Mean 3.0 & & \\
\hline
\end{tabular}


Q4 How helpful have the following development office features been to the school in its attempt to obtain philanthropic support from 1987-88 to $1990-91$ :

- Tenure of senior development officer

Deans

VALUE $\quad F \quad \%$

Very Unhlpil (1)

Gen Unhlpil (2)

Gen Hill (3)

Very Hill (4)

Not Appl (5)

Missing (9)

Mean 3.3

SD 0.5

\section{Development Officers}

YALUE $\quad F \quad \%$

Very Unhlpil (1) $\quad 00.0$

Gen Unhipfl (2) $\quad 1 \quad 25.0$

Gen Hlpfl (3) 250.0

$\begin{array}{lll}\text { Very Hlpfl (4) } & 0 & 00.0\end{array}$

$\begin{array}{lll}\text { Not Appl (5) } & 1 & 25.0\end{array}$

Missing (9) $\quad$ e $\quad 000$

$4 \quad 100.0$

Mean $3.3 \quad$ SD 1.3
- Professional background of senior development officer Deans

VALUE $\quad F \quad \%$

Very Unhlpil (1)

Gen Unhlpfl (2)

Gen Hlpill (3)

Very HIpfl (4)

Not Appl (5)

Missing (9)

$0 \quad 00.0$

250.0

250.0

$0 \quad 00.0$

$0 \quad 00.0$

$4 \quad 100.0$

Mean 3.5
Development Officers

VALUE $\quad F \quad \%$

$\begin{array}{lll}\text { Very Unhlpil (1) } & 0 & 00.0\end{array}$

Gen Unhlpfl (2) $\quad 1 \quad 25.0$

Gen Hllfil (3) $\quad 1 \quad 25.0$

$\begin{array}{lll}\text { Very Hllpfl (4) } \quad 2 & 50.0\end{array}$

$\begin{array}{lll}\text { Not Appl (5) } & 0 & 00.0\end{array}$

Missing (9) $\quad 2 \quad 00.0$

$4 \quad 100.0$

Mean 3.3 SD 1.0 
- Full-time staff/development office

Deans

$\begin{array}{lll}\text { VALUE } & \text { F } & \% \\ \text { Very Unhlpil (1) } & 0 & 00.0 \\ \text { Gen Unhlpil (2) } & 0 & 00.0 \\ \text { Gen Hlpfl (3) } & 1 & 25.0 \\ \text { Very Hllpil (4) } & 2 & 50.0 \\ \text { Not Appl (5) } & 1 & 25.0 \\ \text { Missing (9) } & 0 & 00.0 \\ & 4 & 100.0\end{array}$

Mean 4.0

SD 0.8

- Time spend researching potential prospects

Deans

\begin{tabular}{lll} 
VALUE & F & $\%$ \\
\hline Very Unhlpil (1) & 0 & 00.0 \\
Gen Unhlpfl (2) & 2 & 50.0 \\
Gen Hlpil (3) & 2 & 50.0 \\
Very Hlpfl (4) & 0 & 00.0 \\
Not Appl (5) & 0 & 00.0 \\
Missing (9) & 0 & 00.0 \\
& 4 & 100.0
\end{tabular}

Mean 2.5

SD 0.6

- Strategic planning

Deans

$\begin{array}{lll}\text { YALUE } & \text { F } & \% \\ \text { Very Unhlpfl (1) } & 0 & 00.0 \\ \text { Gen Unhlpfl (2) } & 1 & 25.0 \\ \text { Gen Hlpfl (3) } & 2 & 50.0 \\ \text { Very Hlpfl (4) } & 1 & 25.0 \\ \text { Not Appl (5) } & 0 & 00.0 \\ \text { Missing (9) } & \text { l } & 00.0 \\ & 4 & 100.0\end{array}$

Mean 3.0

SD 0.8
Develooment Officers

VALUE $\quad F \quad \%$

$\begin{array}{lll}\text { Very Unhlpfl (1) } \quad 00.0 & 0\end{array}$

Gen Unhlpil (2) $\quad 2 \quad 50.0$

Gen Hllpil (3) $\quad 1 \quad 25.0$

$\begin{array}{lll}\text { Very Hllf (4) } \quad 1 & 25.0\end{array}$

$\begin{array}{lll}\text { Not Appl (5) } & 0 & 00.0\end{array}$

Missing (9) \&

$4 \quad 100.0$

Mean $2.8 \quad$ SD 1.0

\section{Development Officers}

$\begin{array}{lll}\text { VALUE } & \text { F } & \% \\ \text { Very Unhlpfl (1) } & 0 & 00.0 \\ \text { Gen Unhlpil (2) } & 1 & 25.0 \\ \text { Gen Hlpfl (3) } & 1 & 25.0 \\ \text { Very Hlpil (4) } & 1 & 25.0 \\ \text { Not Appl (5) } & 0 & 00.0 \\ \text { Missing (9) } & 1 & 25.0 \\ & 4 & 100.0\end{array}$

Mean $3.0 \quad$ SD 1.0

\section{Develooment Officers}

VALUE $\quad F \quad \%$

Very Unhlpfl (1) $\quad 0 \quad 00.0$

Gen Unhlpfl (2) $0 \quad 00.0$

Gen Hllil (3) $2 \quad 50.0$

Very Hllpil (4) $\quad 1 \quad 25.0$

Not Appl (5) $\quad 1 \quad 25.0$

Missing (9) $Q \quad \underline{000}$

$4 \quad 100.0$

Mean 3.8 SD 1.0 
Deans

$\begin{array}{lll}\text { VALUE } & \text { F } & \% \\ \text { Very Unhlpfl (1) } & 0 & 00.0 \\ \text { Gen Unhlpil (2) } & 1 & 25.0 \\ \text { Gen Hlpfl (3) } & 2 & 50.0 \\ \text { Very Hlpfll (4) } & 0 & 00.0 \\ \text { Not Appl (5) } & 1 & 25.0 \\ \text { Missing (9) } & 0 & 00.0 \\ & 4 & 100.0\end{array}$

Mean 3.3

SD 1.3

\section{Development Officers}

\begin{tabular}{lll} 
VALUE & F & $\%$ \\
\hline Very Unhlpfl (1) & 0 & 00.0 \\
Gen Unhlpfl (2) & 3 & 75.0 \\
Gen Hlpfl (3) & 0 & 00.0 \\
Very HIpfl (4) & 0 & 00.0 \\
Not Appl (5) & 0 & 00.0 \\
Missing (9) & 1 & 25.0 \\
& 4 & 100.0
\end{tabular}

Mean $2.0 \quad$ SD 0.0

- Quality of proposals

Deans

\section{VALUE}

Very Unhlpil (1)

Gen Unhlpfl (2)

Gen Hilpil (3)

Very Hipil (4)

Not Appl (5)

Missing (9)

Mean 4.0

SD 0.8
Development Officers

\begin{tabular}{lll} 
VALUE & F & $\%$ \\
\hline Very Unhlpfl (1) & 0 & 00.0 \\
Gen Unhlpfl (2) & 1 & 25.0 \\
Gen Hlpfl (3) & 0 & 00.0 \\
Very Hlpfl (4) & 2 & 50.0 \\
Not Appl (5) & 0 & 00.0 \\
Missing (9) & 1 & 25.0 \\
& 4 & 100.0
\end{tabular}

Mean 3.3

SD 1.1

Q.5 How often did you participate in the following activities in the last academic year:

0 Discuss grant application with development officer

Deans

\begin{tabular}{lll} 
VAlLUE & F & $\%$ \\
\hline Within 1-3 mos. (1) & 1 & 25.0 \\
Within 4-6 mos. (2) & 0 & 00,0 \\
Within 7-9 mos. (3) & 0 & 00.0 \\
Within 10-12 mos. (4) & 0 & 00.0 \\
Nol Appl (5) & 3 & 75.0 \\
Missing (9) & $\ell$ & 00.0 \\
& 4 & 100.0
\end{tabular}

Mean $4.0 \quad$ SD 2.0 
- Discuss grant application with dean

Develoement Officers

$\begin{array}{lll}\text { VAlUE } & F & \% \\ \text { Within 1-3 mos. (1) } & 3 & 75.0 \\ \text { Within 4-6 mos. (2) } & 0 & 00.0 \\ \text { Within 7-9 mos. (3) } & 0 & 00.0 \\ \text { Within 10-12 mos. (4) } & 1 & 25.0 \\ \text { Not Appl (5) } & 0 & 00.0 \\ \text { Missing (9) } & 0 & 00.0 \\ & 4 & 100.0\end{array}$

Mean 1.8 SD 1.5

0 Visit major funding prospect

Deans

VALUE $\quad F \quad \%$

Within 1-3 mos. (1) $\quad 2 \quad 50.0$

Within 4-6 mos. (2) $\quad 1 \quad 25.0$

Within 7.9 mos. (3) $\quad 0 \quad 00.0$

Within 10-12 mos. (4) $\quad 0 \quad 00.0$

$\begin{array}{lll}\text { Not Appl (5) } & 1 & 25.0\end{array}$

Missing (9) $\quad$ l $\quad \underline{000}$

$4 \quad 100.0$

Mean 2.3

SD 1.9

\section{Development Officers}

$\begin{array}{lll}\text { VALUE } & F & \% \\ \text { Within 1-3 mos. (1) } & 1 & 25.0 \\ \text { Within 4-6 mos. (2) } & 2 & 50.0 \\ \text { Within 7-9 mos. (3) } & 0 & 00.0 \\ \text { Within 10-12 mos. (4) } & 1 & 25.0 \\ \text { Not Appl (5) } & 0 & 00.0 \\ \text { Missing (9) } & 0 & 00.0 \\ & 4 & 100.0\end{array}$

Mean $2.3 \quad$ SD 1.3

0 Discuss funding sources with the development officer

Deans

YALUE $\%$

$\begin{array}{lll}\text { Within 1-3 mos. (1) } & 4 & 100.0 \\ \text { Within 4-6 mos. (2) } & 0 & 000.0 \\ \text { Within 7-9 mos. (3) } & 0 & 000.0 \\ \text { Within 10-12 mos. (4) } & 0 & 000.0 \\ \text { Not Appl (5) } & 0 & 000.0 \\ \text { Missing (9) } & \ell & 000.0 \\ & 4 & 100.0\end{array}$

Mean 1.0 
- Discuss funding sources with the dean

Development Officers

\begin{tabular}{lll} 
VALUE & F & $\%$ \\
\hline Within 1-3 mos. (1) & 4 & 100.0 \\
Within 4-6 mos. (2) & 0 & 000.0 \\
Within 7-9 mos. (3) & 0 & 000.0 \\
Within 10-12 mos. (4) & 0 & 000.0 \\
Not Appl (5) & 0 & 000.0 \\
Missing (9) & $\underline{000.0}$ \\
& 4 & 100.0
\end{tabular}

Mean $1.0 \quad$ SD 0.0

- Meeting with volunteers

Deans

VALUE

F $\%$

Within $1-3$ mos. (1)

$3 \quad 75.0$

Within 4-6 mos. (2)

Within 7-9 mos. (3)

Within $10-12$ mos. (4)

Not Appl (5)

Missing (9)

125.0

$0 \quad 00.0$

000

000.0

l. $\quad 00.0$

$4 \quad 100.0$

Mean 1.3

SD 0.5

\section{Development Officers}

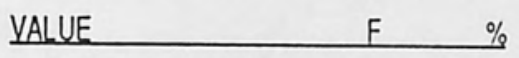

Within $1-3$ mos. (1) $\quad 4 \quad 100.0$

Within 4-6 mos. (2) $\quad 0 \quad 000.0$

$\begin{array}{lll}\text { Within } 7-9 \text { mos. (3) } & 0 & 000.0\end{array}$

Within 10-12 mos. (4) $\quad 0 \quad 000.0$

$\begin{array}{lll}\text { Not Appl (5) } & 0 & 000.0\end{array}$

$\begin{array}{lll}\text { Missing (9) } & l & 0000\end{array}$

$4 \quad 100.0$

Mean $1.0 \quad$ SD 0.0 
APPENDIX

N

385 
The population of the study consisted of 55 private and public American schools of dentistry including Puerto Rico. The sample selected was the entire population - a census. They are listed below according to geographical location and alphabetically:

\section{ALABAMA}

University of Alabama School of Dentistry

University of Alabama at Birmingham

UAB Station

Birmingham, Alabama 35294

\section{CALIFORNIA}

University of California, Los Angeles, School of Dentistry

Center for the Health Sciences

Los Angeles, California 90024-1668

University of California, San Francisco, School of Dentistry

Third and Parnassus Avenues

San Francisco, California 94143

School of Dentistry

Loma Linda University

Loma Linda, California 92350

School of Dentistry

University of the Pacific

2155 Webster Street

San Francisco, California 94115 
CALIFORNIA (cont'd.)

University of Southern California School of Dentistry University Park - MC-0641

Los Angeles, California 90089-0641

\section{COLORADO}

University of Colorado School of Dentistry

4200 E. Ninth Avenue, Box C-284

Denver, Colorado 80262

\section{CONNECTICUT}

University of Connecticut School of Dental Medicine

263 Farmington Avenue

Farmington, Connecticut 06030

\section{DISTRICT OF COLUMBIA}

Howard University College of Dentistry

600 W Street, N.W.

Washington, DC 20059

\section{ELORIDA}

University of Florida College of Dentistry

Box J-405, JHMHC

Gainesville, Florida 32610 


\section{GEORGA}

Medical College of Georgia School of Dentistry

Augusta, Georgia 30912

LLINOIS

College of Dentistry

University of Illinois at Chicago

801 S. Paulina Street

Chicago, Illinois 60612

Loyola University of Chicago School of Dentistry

2160 S. First Avenue

Maywood, Illinois 60153

Northwestern University Dental School

240 E. Huron Avenue

Chicago, Illinois 60611-2972

Southern Illinois University School of Dental Medicine 2800 College Avenue

Alton, Illinois 62002

\section{INDIANA}

Indiana University School of Dentistry

1121 W. Michigan Street

Indianapolis, Indiana 46202-5186 
IOWA

College of Dentistry

University of lowa

lowa City, lowa 52242

\section{KENTUCKY}

University of Kentucky College of Dentistry

800 Rose Street

Lexington, Kentucky 40536

School of Dentistry

University of Louisville

Louisville, Kentucky 40292

\section{LOUISIANA}

Louisiana State University School of Dentistry

1100 Florida Avenue

New Orleans, Louisiana 70119

\section{MARYLAND}

Baltimore College of Dental Surgery

Dental School

University of Maryland at Baltimore

666 W. Baltimore Street

Baltimore, Maryland 21201 


\section{MASSACHUSEITS}

Henry M. Goldman School of Graduate Dentistry

Boston University

100 E. Newton Street

Boston, Massachusetts 02118

Harvard School of Dental Medicine

188 Longwood Avenue

Boston, Massachusetts 02115

Tufts University School of Dental Medicine

1 Kneeland Street

Boston, Massachusetts 02111

\section{MICHIGAN}

University of Detroit School of Dentistry

2985 E. Jefferson Avenue

Detroit, Michigan 48207

University of Michigan School of Dentistry

Ann Arbor, Michigan 48109-1078

\section{MINNESOTA}

University of Minnesota School of Dentistry

515 Delaware Street S.E.

Minneapolis, Minnesota 55455 


\section{MISSISSIPPI}

University of Mississippi School of Dentistry 2500 N. State Street

Jackson, Mississippi 39216-4505

MISSOURI

University of Missouri-Kansas City

School of Dentistry

630 E. 25th Street

Kansas City, Missouri 64108

\section{NEBRASKA}

School of Dentistry

Creighton University

2500 California Street

Omaha, Nebraska 68178

College of Dentistry

University of Nebraska Medical Center

40th and Holdrege Streets

Lincoln, Nebraska 68583-0740

\section{NEW JERSEY}

University of Medicine and Dentistry of New Jersey

New Jersey Dental School

110 Bergen Street

Newark, New Jersey 07103-2425 


\section{NEWYORK}

Columbia University School of Dental and Oral Surgery 630 W. 168th Street

New York, New York 10032

New York University College of Dentistry

345 East 24th Street

New York, New York 10010-4099

School of Dental Medicine

State University of New York at Buffalo

325 Squire Hall

Buffalo, New York 14214

School of Dental Medicine

State University of New York at Stony Brook

Health Sciences Center

Stony Brook, Long Island, New York 11794-8700

\section{NORTHCAROLINA}

School of Dentistry

University of North Carolina at Chapel Hill

CB \# 7450, Brauer Hall

Chapel Hill, North Carolina 27599-7450

$\underline{O H O}$

Case Western Reserve University School of Dentistry 2123 Abington Road

Cleveland, Ohio 44106 
$\mathrm{OHIO}$ (cont'd.)

Ohio State University College of Dentistry

305 W. 12th Avenue

Columbus, Ohio 43210

\section{OKLAHOMA}

University of Oklahoma College of Dentistry

1001 N. E. Stanton L. Young

Oklahoma City, Oklahoma 73190

\section{ORECON}

School of Dentistry

Oregon Health Sciences University

611 S. W. Campus Drive

Portland, Oregon 97201

\section{PENNSYLVANIA}

University of Pennsylvania School of Dental Medicine 4001 Spruce Street

Philadelphia, Pennsylvania 19104

University of Pittsburgh School of Dental Medicine

C-3з3 Salk Hall

3501 Terrace Street

Pittsburgh, Pennsylvania 15261 


\section{PENNSYLVANIA (cont'd.)}

Temple University School of Dentistry

3223 N. Broad Street

Philadelphia, Pennsylvania 19140

\section{SOUTHCAROUNA}

College of Dental Medicine

Medical University of South Carolina

171 Ashley Avenue

Charleston, South Carolina 29425

\section{IENNESSEE}

School of Dentistry

Meharry Medical College

D. B. Todd Boulevard

Nashville, Tennessee 37208

University of Tennessee College of Dentistry

875 Union Avenue

Memphis, Tennessee 38163

IEXAS

Baylor College of Dentistry

3302 Gaston Avenue

Dallas, Texas 75246 
IEXAS (cont'd.)

University of Texas Health Science Center at Houston, Dental Branch

P. O. Box 20068

Houston, Texas 77225

University of Texas Health Science Center at San Antonio

Dental School

7703 Floyd Curl Drive

San Antonio, Texas 78284-7906

VIRGINIA

School of Dentistry

Medical College of Virginia

Virginia Commonwealth University

Box 566

Richmond, Virginia 23298

WASHINGTON

University of Washington School of Dentistry

Health Sciences Building SC 62

Seattle, Washington 98195

\section{WEST VIRGINIA}

West Virginia University School of Dentistry

Health Sciences Center North

Morgantown, West Virginia 26506 
WISCONSIN

Marquette University School of Dentistry

604 N. 16th Street

Milwaukee, Wisconsin 53233

\section{PUERTORICO}

University of Puerto Rico School of Dentistry

Medical Sciences Campus

G.P.O. Box 5067

San Juan, Puerto Rico 00936 